\title{
IN SITU INFRARED STUDY OF CATÁ DECOMPOSITION OF NITRIC OXIDE (NO)
}

\author{
Final Report
}

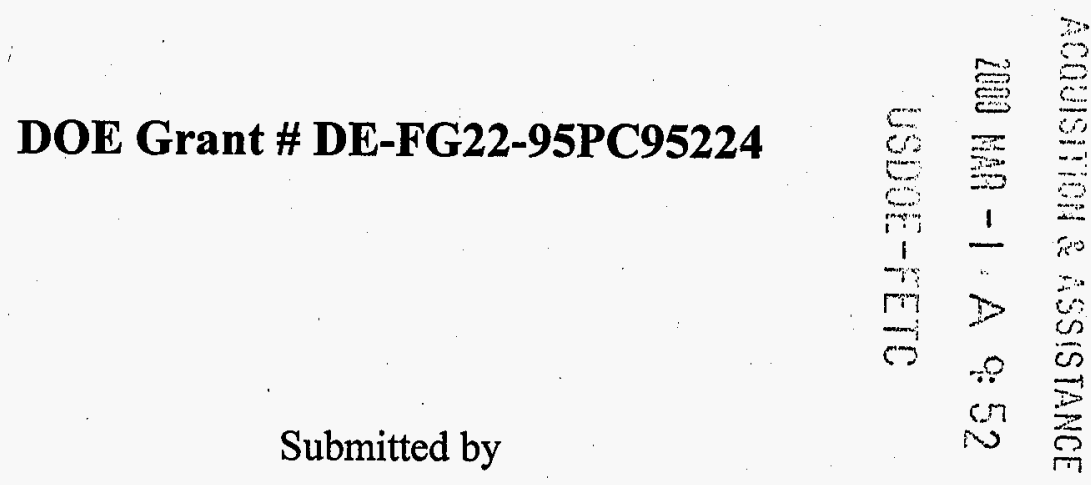

Steven S. C. Chuang*

Department of Chemical Engineering

The University of Akron

Akron $\mathrm{OH}$ 44325-3906

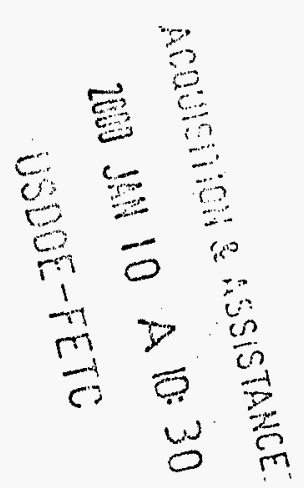

"Tel.: (330) 972 6993, Fax : (330) 972 5856, e-mail: schuang@uakron.edu 
TITLE: IN SITU INFRARED STUDY OF CATALYTIC DECOMPOSITION OF NITRIC OXIDE (NO)

GRANT NUMBER: DE-FG22-95PC95224

UNIVERSITY: - The University of Akron

DATE OF REPORT: December 31, 1999

GRANT DATE: $\quad 8 / 1 / 95-7 / 31 / 98$

ACTUAL COMPLETED DATE: $8 / 31 / 98$

PROGRAM MANAGER: Dr. M. Perry

PRINCIPAL INVESTIGATOR: Steven S. C. Chuang

CONTRACTING OFFICER'S REPRESENTATIVE: Eric T. Bell

REPORTING PERIOD: FINAL REPORT 


\section{DISCLAIMER}

This report was prepared as an account of work sponsored by an agency of the United States Government. Neither the United States Government nor any agency thereof, nor any of their employees, makes any warranty, express or implied, or assumes any legal liability or responsibility for the accuracy, completeness, or usefulness of any information, apparatus, product, or process disclosed, or represents that its use would not infringe privately owned rights. Reference herein to any specific commercial product, process, or service by trade name, trademark, manufacturer, or otherwise does not necessarily constitute or imply its endorsement, recommendation, or favoring by the United States Government or any agency thereof. The views and opinions of authors expressed herein do not necessarily state or reflect those of the United States Government or any agency thereof. 


\begin{abstract}
The growing concerns for the environment and increasingly stringent standards for NO emission have presented a major challenge to control NO emissions from electric utility plants and automobiles. Catalytic decomposition of NO is the most attractive approach for the control of NO emission for its simplicity. Successful development of an effective catalyst for NO decomposition will greatly decrease the equipment and operation cost of NO control. Due to lack of understanding of the mechanism of NO decomposition, efforts on the search of an effective catalyst have been unsuccessful.

Scientific development of an effective catalyst requires fundamental understanding of the nature of active site, the rate-limiting step, and an approach to prolong the life of the catalyst. We have investigated the feasibility of two novel approaches for improving catalyst activity and resistance to sintering. The first approach is the use of silanation to stabilize metal crystallites and supports for $\mathrm{Cu}-\mathrm{ZSM}-5$ and promoted Pt catalysts; the second is utilization of oxygen spillover and desorption to enhance NO decomposition activity. The silanation approach failed to stabilize $\mathrm{Cu}-\mathrm{ZSM}-5$ activity under hydrothermal condition. Silanation blocked the oxygen migration and inhibited oxygen desorption. Oxygen spillover was found to be an effective approach for promoting NO decomposition activity on Pt-based catalysts. Detailed mechanistic study revealed the oxygen inhibition in NO decomposition and reduction as the most critical issue in developing an effective catalytic approach for controlling NO emission.
\end{abstract}




\section{TABLE OF CONTENTS}

Title Page

Disclaimer

Abstract

Table of Contents

Executive Summary

Introduction

Discussion

a. Investigation of the Reactivity of Adsorbates and the Nature of Sites in the Direct $\mathrm{NO}$ and $\mathrm{N}_{2} \mathrm{O}$ Decomposition on $\mathrm{Cu}-\mathrm{ZSM}-5$

b. Determination of the feasibility of Using Silanation to Stabilize $\mathrm{Cu}-\mathrm{ZSM}-5$ and to Improve its Resistance to Sintering and Dealumination

c. Investigation of the Mechanism of NO Dissociation, Oxygen Spillover, and Oxygen Desorption on Tb-Pt Catalysts

d. Determination of the Effectiveness of Using Oxygen Spillover and Carbon to Promote NO Dissociation Activity on $\mathrm{Rh}$ and $\mathrm{Pd}$

e. Determination of the Nature of $\mathrm{NO} / \mathrm{O}_{2}$ Adsorbates on $\mathrm{Tb}, \mathrm{La}, \mathrm{Ba}$, and $\mathrm{Mg}$ Oxides

f. Determination of the Nature of $\mathrm{NO}$ and $\mathrm{CO}$ Adsorbates on the Rh 


\section{EXECUTIVE SUMMARY}

This study has determined the dynamic behavior of adsorbed species during NO decomposition on $\mathrm{Cu}-\mathrm{ZSM}-5, \mathrm{~Tb}-\mathrm{Pt} / \mathrm{Al}_{2} \mathrm{O}_{3}$, and carbon-supported $\mathrm{Rh}$ and $\mathrm{Pd}$ catalysts as well as NO reduction on $\mathrm{Rh} / \mathrm{SiO}_{2}$ catalysts. The results of this study allow elucidation of the reaction mechanism for NO decomposition and reduction.

The common steps involved in the NO decomposition and reduction is the dissociation of adsorbed $\mathrm{NO}$ to adsorbed $\mathrm{N}$ and $\mathrm{O}$. Combination of adsorbed $\mathrm{N}$ to produce $\mathrm{N}_{2}$ has been demonstrated to be a facile step while removal of adsorbed $O$ has been a very difficult step. Adsorbed oxygen has to be removed from NO dissociate site so that NO dissociation step can continue. Understanding of the type of adsorbed NO that dissociates and the approach for removal of adsorbed oxygen hold the key to develop an effective catalyst for NO decomposition and reduction.

\section{NO decomposition}

We have investigated the NO decomposition mechanism over two types of catalysts: $\mathrm{Cu}$ ZSM-5 and Tb-Pt/ $/ \mathrm{Al}_{2} \mathrm{O}_{3}$. The activity of Cu-ZSM-5 was found to lie on its ability to maintain $\mathrm{Cu}$ at +1 state through auto-reduction and decomposition of $\mathrm{Cu}^{2+}\left(\mathrm{NO}_{3}\right)_{2}$ to $\mathrm{Cu}^{+} . \mathrm{Cu}^{+}(\mathrm{NO})$ was identified as a precursor for $\mathrm{NO}$ dissociation and reaction with adsorbed $\mathrm{N}$ to produce $\mathrm{N}_{2} \mathrm{O}$. Oxygen removal from Cu-ZSM-5 surface involved both auto-reduction of Cu-ZSM-5 and decomposition of $\mathrm{Cu}^{2+}\left(\mathrm{NO}_{3}\right)_{2}$ to $\mathrm{Cu}^{+}$. Removal of hydroxyl group by silane did not stabilize the Cu-ZSM-5 against deactivation. In contrast, silanation block the oxygen migration, inhibiting oxygen desorption. 
The activity of $\mathrm{Tb}-\mathrm{Pt} / \mathrm{Al}_{2} \mathrm{O}_{3}$ lies on the ability to spillover oxygen from $\mathrm{Pt}$ site (which dissociates NO) to Tb oxide site. Infrared study showed that spill-over oxygen combines with adsorbed $\mathrm{NO}$ on $\mathrm{Tb}$ oxide to produce $\mathrm{Tb}\left(\mathrm{NO}_{3}\right)_{2}$ which further decomposed to $\mathrm{N}_{2}$ and $\mathrm{O}_{2}$.

Although the pathway for NO dissociation and oxygen desorption have been identified, the approach for facilitating oxygen desorption, especially in an oxidizing environment, remains to be investigated.

\section{NO Reduction}

Infrared study of the NO-CO reaction on $\mathrm{Rh}$ catalyst showed that $\mathrm{Rh}^{0}-\mathrm{NO}$ is the precursor for NO dissociation. Oxygen from NO dissociation can further react with linear CO and gem-dicarbonyl to form $\mathrm{CO}_{2}$. On carbon-supported $\mathrm{Rh}$ catalyst, oxygen from NO dissociation can further react with carbon to produce $\mathrm{CO}$. The critical problem remains to be addressed is how to abate oxygen adsorption during NO-CO reaction in the oxidizing environment. This study has identified the oxygen inhibition in NO decomposition and reduction as the most critical issue in developing an effective catalytic approach for controlling NO emission. 


\section{INTRODUCTION}

NO is a major pollutant in the exhaust of various combustion processes (1-21). Depending on the nature of combustion processes, various catalytic and non-catalytic schemes have been devised to remove NO from exhaust streams (1-3). Catalytic approaches for the removal of NO include [i] the reaction of NO with $\mathrm{CO}$ over $\mathrm{Rh}-\mathrm{Pt}$ and Pd-based catalysts in the catalytic converter (1-4), [ii] the reaction of $\mathrm{NO}$ and $\mathrm{CO}$ on metal oxides (5), [iii] the reaction of NO with hydrocarbons on Cu- and Co-ZSM-5 (7,10-12) and alkali-MgO catalysts (8), [iv] the selective catalytic reduction (SCR) of $\mathrm{NO}_{\text {with }} \mathrm{NH}_{3}(3,20,21)$, and [v] the direct decomposition of NO over Cu-based catalysts $(1,6,9,19)$. Rh-Pt and Pd catalysts (three-way catalysts) have been successfully commercialized to simultaneously remove $\mathrm{NO}, \mathrm{CO}$, and hydrocarbons from automobile exhausts. Due to the high cost of noble metals (Rh; Pt, and Pd), extensive research has been aimed at development of low-cost metal oxide substitutes $(3,5)$. So far these efforts have been unsuccessful. Although three-way catalysts work well for controlling the emission of pollutants from the current mode of operation for the internal combustion engine, the effectiveness of the three-way catalyst decreases dramatically as the composition of flue gas deviates from those produced by the stoichiometric combustion of gasoline.

Exhaust streams of the coal-fired plant, diesel engine, and lean-burn engine contain excess air and lean $\mathrm{CO}$ which make three-way catalysts ineffective for NO reduction (1-3). Selective catalytic reduction ( $4 \mathrm{NO}+4 \mathrm{NH}_{3}+\mathrm{O}_{2} \Rightarrow 4 \mathrm{~N}_{2}+6 \mathrm{H}_{2} \mathrm{O} ; 6 \mathrm{NO}+4 \mathrm{NH}_{3} \Rightarrow 5 \mathrm{~N}_{2}+$ $6 \mathrm{H}_{2} \mathrm{O}$ ) over W, V, Mo, and Ti oxide catalysts has been used to control $\mathrm{NO}_{\mathrm{x}}$ emission from coalfired plants $(1,20)$. The advantage of catalytic approach is the high effectiveness of NO removal. However, the use of $\mathrm{NH}_{3}$ in the selective catalytic reduction (SCR) requires large size of reactor and very high equipment and operation costs $(1,20,21)$. Furthermore, excess $\mathrm{NH}_{3}$ is required to increase the effectiveness of $\mathrm{NO}$ reduction. The excess $\mathrm{NH}_{3}$ also leads to the emission of unreacted $\mathrm{NH}_{3}$ (ammonia slip) to the atmosphere. To overcome ammonia slip, the reaction of NO with hydrocarbons on Co-ZSM-5, Cu-ZSM-5 (7,10-12), and alkali-MgO catalysts (8) has 
been extensively studied to replace $\mathrm{NH}_{3}$ as a reducing agent. Although these catalysts show promising activities, the processes also face problems of hydrocarbon slip and additional cost of adding hydrocarbons as reactants.

The direct decomposition of $\mathrm{NO}$ to harmless nitrogen $\left(\mathrm{N}_{2}\right)$ and oxygen $\left(\mathrm{O}_{2}\right)$ is an attractive approach to remove NO from exhaust streams $(1,6,9,22)$. The direct decomposition, $2 \mathrm{NO} \Rightarrow \mathrm{N}_{2}+\mathrm{O}_{2}$, is thermodynamically favorable at temperatures below $1000 \mathrm{~K}$. Development of an effective catalyst for the direct decomposition of NO will eliminate the use of $\mathrm{NH}_{3}$ and hydrocarbons, significantly simplifying the NO removal process, and dramatically decreasing the cost of NO control. Such a catalyst would be particularly useful for reducing NO emission from diesel engines, lean-burn gasoline engines, and coal-fired plants. Extensive catalyst search and screening studies for the last two decades have led to the discovery of $\mathrm{Cu}$ ZSM-5 catalysts, which exhibit promising activities for the direct decomposition of NO $(1,6,9,22,23)$. However, the catalyst is susceptible to $\mathrm{SO}_{2}$-poisoning and deactivation caused by $\mathrm{H}_{2} \mathrm{O}(1,3,10,11) . \mathrm{SO}_{2}$-poisoning has also been observed on the $\mathrm{SCR}$ catalyst. $\mathrm{SO}_{2}$-poisoning has been alleviated by placing the catalytic $\mathrm{NO}$ removal unit after an $\mathrm{SO}_{2}$ scrubber and adjusting SCR reactor temperature (21). $\mathrm{H}_{2} \mathrm{O}$, a major product of the combustion process, is also present after $\mathrm{SO}_{2}$ scrubbing. $\mathrm{H}_{2} \mathrm{O}$ promotes sintering of $\mathrm{Cu}$ crystallite which leads to the formation of large $\mathrm{Cu}$ crystallites, further disrupting the zeolite framework, and causing the loss of activity of Cu-ZSM-5 for the reduction of $\mathrm{NO}(10) . \mathrm{H}_{2} \mathrm{O}$ also induces migration of silica in zeolite leading to dealumination, causing degradation of crystalline zeolite (11).

Inhibition of sintering and dealumination processes will prolong the life of Cu-ZSM-5 catalysts and may bring the $\mathrm{Cu}$-based catalysts closer to practical application for NO reduction. One possible approach to inhibit the sintering of support and to improve its hydrothermal stability is the utilization of a silane species to selectively react with the $\mathrm{OH}$ group on the surface of supports such as $\gamma$-alumina and zeolites. The silanation can impart hydrophobicity to the oxide surface (24). Therefore, water does not adsorb on the surface to form hydroxyl groups and then further react with $\mathrm{Al}$ or $\mathrm{Si}$ species to cause dealumination. Silanation also adds $\mathrm{Si}$ 
impurities to the catalyst surface which hinder sintering of metal crystallites. Silanation may provide a unique opportunity to stabilize $\mathrm{Cu}$ crystallites and zeolite surface in the presence of steam, a major component of the exhaust gas.

Extensive catalyst screening studies for NO decomposition have also led to a conjecture that low NO decomposition activity of a catalyst is a result of the inability to desorb oxygen produced from NO dissociation (25-27). The oxygen dissociated from NO is strongly bonded to the catalyst surface, preventing further decomposition of NO. Results of temperatureprogrammed decomposition of NO have shown that oxygen from NO dissociation desorbs at 630 $\mathrm{K}$ on Cu-ZSM-5 (currently the best NO decomposition catalyst ) while oxygen desorbs at 1100 $\mathrm{K}$ on $\mathrm{Rh}$ catalyst which is the most active for NO-CO reaction but not effective for NO decomposition $(25,26)$. An important question to be addressed is why Cu-ZSM-5 is so unique in the oxygen desorption and NO decomposition. A fundamental understanding of NO decomposition mechanism will permit further improvement of the catalyst so that the size of reactor for the NO decomposition can be decreased, and thereby, the cost of capital investment and operation.

The activity of a catalyst for the direct NO decomposition appears to depend on its capability to desorb oxygen at temperatures where NO dissociates (23). One possible approach to improve the activity of NO decomposition is to promote the spillover of adsorbed oxygen and desorption of oxygen at temperatures where NO dissociates. Promotion of oxygen spillover and desorption should create free sites needed for NO dissociation. Recent studies have revealed that $\mathrm{Tb}$ oxides promote the activity of $\mathrm{Pt} / \mathrm{Al}_{2} \mathrm{O}_{3}$ catalyst for $\mathrm{NO}$ decomposition probably through enhancing oxygen spillover and desorption (27). Fundamental understanding of spillover and desorption of oxygen on Tb-Pt catalyst may provide a scientific basis to design a highly active catalyst for the direct NO decomposition.

This study is aimed at elucidating the mechanism of the direct NO decomposition on $\mathrm{Cu}$ ZSM-5 catalyst and at investigating the feasibility of two novel approaches, i.e., (i) using silanation to improve the catalyst resistance to sintering and dealumination and (ii) promoting 
oxygen spillover and desorption to enhance the activity of catalyst for NO decomposition. The specific objectives of the proposal include the following:

1. Investigation of the reactivity of adsorbates and the nature of sites in the direct $\mathrm{NO}$ and $\mathrm{N}_{2} \mathrm{O}$ decomposition on Cu-ZSM-5.

2. Determination of the feasibility of using silanation to stabilize Cu-ZSM-5 and to improve its resistance to sintering and dealumination.

3. Investigation of the mechanism of NO dissociation, oxygen spillover, and oxygen desorption on $\mathrm{Tb}-\mathrm{Pt}$ catalysts.

4. Determination of the effectiveness of using oxygen spillover and carbon to promote NO dissociation activity on $\mathrm{Rh}$ and $\mathrm{Pd}$.

5. Determination of the nature of $\mathrm{NO} / \mathrm{O}_{2}$ adsorbates on $\mathrm{Tb}, \mathrm{La}, \mathrm{Ba}$, and $\mathrm{Mg}$ oxides.

6. Determination of the nature of $\mathrm{NO}$ and $\mathrm{CO}$ adsorbate on the $\mathrm{Rh}$ Catalysts

The reactivity of adsorbates, silanation, and oxygen spillover will be studied with an in situ infrared reactor system which allows simultaneous determination of structure and concentration of adsorbates and gaseous products. Correlation between concentration of adsorbates and gaseous products allows determination of active adsorbates and sites to which the adsorbates bind. The knowledge of active sites may provide the scientific basis for developing preparation methods to populate catalyst surface with highly active sites. An effective catalyst is required to exhibit not only high activity and selectivity but also resistance to deactivation. Understanding of silanation mechanism and its impact on the catalyst activity will permit evaluation of the effectiveness of the silanation approach to improve catalyst resistance to sintering and dealumination. 


\section{LITERATURE REFERENCES}

1. Iwamoto, M., in "Future Opportunities in Catalytic and Separation Technology," p. 121, Elsevier, Amsterdam-Oxford-New York-Tokyo, 1990.

2. Taylor, K. C., Catal. Rev.-Sci. Eng. 35(4), 457 (1993).

3. Farrauto, R. J., Heck, R. M., and Speronello, B. K., Chem. and Eng. News, Sept. 7, 34 (1992).

4. Summers, J. C., and Williamson, W. B., in "Environmental Catalysis," (J. N. Armor, Ed.), ACS Symposium Series 552, p. 96, ACS, Washington, D.C., 1994.

5. Viswanathan, B., Catal. Rev.-Sci. Eng. 34(4), 337 (1992).

6. Li, Y., and Hall, W., J. Phys Chem. 94, 6145 (1990).

7. Armor, J. N., and Li, Y., Preprints of NOx Reduction Symposium, p. 141, Division of Petroleum Chemistry, Inc. ACS, Washington, D. C. 1994.

8. Zhang, X., Walters, A. B., and Vannice, M. A., Prints of $\mathrm{NO}_{\mathrm{X}}$ Reduction Symposium, p. 145, Division of Petroleum Chemistry, Inc. ACS, Washington, D. C., 1994.

9. Iwamoto, M., Yahiro, H., Tanaka, K., Mizuno, N., Mine, Y., and Kagawa, S., J. Phys. Chem. 95, 3727 (1991).

10. Kharas, K. C. C., Robta, H. J., and Datye, A., in "Environmental Catalysis," (J. N. Armor, Ed.), ACS Symposium Series 552, p. 39, ACS, Washington, D.C., 1994.

11. Kharas, K. C. C., Robta, H. J., and Liu, D. J., Appl. Catal. B 2. 225 (1993).

12. Jen, H. W., and Gandhi, H. S., in "Environmental Catalysis," (J. N. Armor, Ed.), ACS Symposium Series 552, p. 53, 1994.

13 Zhang, Y., Sun, T., Sarofim, A. F., and Flytzani-Stephanopoulous, M., Preprints of $\mathrm{NO}_{\mathbf{x}}$ Reduction Symposium, p. 171, Division of Petroleum Chemistry, Inc. ACS, Washington, D. C., 1994.

14. Li, Y., Battavio, P. J., and Armor, J. N., J. Catal. 142, 561 (1993).

15. Hecker, W. C., and Bell, A. T., J. Catal.. 59, 223 (1983).

16. Ng, K. Y. S., Belton, D. N., Schmieg, S. J., and Fisher, G. B., J. Catal. 146, 394 (1994). 
17. Oh, S. H., Fisher, G. B., Carpenter, J. E., and Goodman, D. W., J. Catal. 100, 360 (1986).

18. Schwartz, S. B., Fisher, G. B., and Schmidt, L. D., J. Phys. Chem. 92, 389 (1988).

19. Iwamoto, M. H., Yahiro, S., Shundo, Y., and Yu-u, N., Shokubia Mizuno 33, 430 (1990).

20. Wood, S. C., Chem. Eng. Progress p. 32, Jan 1994.

21. Cho, S. M., Chem. Eng. Progress p. 39, Jan 1994.

22. Tamaru, K., and Mills, A., "Catalysts For Control of Exhaust Emissions", in Advanced Heterogeneous Catalysts For Energy Applications, vol. 2, prepared for U.S. Dept. of Energy, Office of Energy Research and Office of Program Analysis, Consultec Scientific Inc, Knoxville, TN, April 1994.

23. Hightower, J. W., and Van Leirsburg, D. A., in "The Catalytic Chemistry of Nitrogen Oxides", (R. L. Klimisch and J. G. Larson, Eds.), p. 63, Plenum Press, New York, 1975.

24. Leyden, D. E. Ed., " Silanes, Surfaces and Interfaces", Gordon and Breach, New York, 1985.

25. Li, Y, and Armor, J. N., Appl. Catal. 76, L1 (1991).

26. Nieuwenhuys, B. E., in "Elementary Reaction Steps in Heterogeneous Catalysis," p. 155, (R. W. Joyner and R. A. van Santen, Eds.), Kluwer Academic Publishers, Netherlands, 1993.

27. Kyomasu, A., Okuhara, T., and Misono, M., Nippon Kagaku Kaishi 5, 651 (1991). 


\section{DISCUSSION}




\title{
Dynamics of $\mathrm{NO}$ and $\mathrm{N}_{2} \mathrm{O}$ Decomposition over Cu-ZSM-5 Under Transient Reducing and Oxidizing Conditions
}

\begin{abstract}
$\mathrm{NO}$ and $\mathrm{N}_{2} \mathrm{O}$ decomposition reaction pathways on $\mathrm{Cu}-\mathrm{ZSM}-5$ have been investigated by monitoring the adsorbate dynamics and changes in reactant and product concentrations under transient reducing and oxidizing conditions. Exposure of $\mathrm{Cu}-\mathrm{ZSM}-5$ to $\mathrm{N}_{2} \mathrm{O}$ at $323 \mathrm{~K}$ resulted in the formation of $\mathrm{Cu}^{+}-\mathrm{N}_{2} \mathrm{O}\left(\mathrm{N}_{2} \mathrm{O}\right.$ adsorbed via $\left.\mathrm{N}\right), \mathrm{Cu}^{+}-\mathrm{ON}_{2}\left(\mathrm{~N}_{2} \mathrm{O}\right.$ adsorbed via $\left.\mathrm{O}\right)$, and bridged nitrato species. Temperature programmed reaction studies reveal the presence of different types of adsorbed $\mathrm{O}$ species produced from the adsorption and surface reaction of $\mathrm{NO}$ and $\mathrm{N}_{2} \mathrm{O}$. Adsorbed $\mathrm{O}$ species produced from $\mathrm{N}_{2} \mathrm{O}$ decomposition reacts with the pulsed $\mathrm{H}_{2}$ to form $\mathrm{Cu}^{+}$$\mathrm{OH}$ and inhibit $\mathrm{O}_{2}$ formation while the adsorbed $\mathrm{O}$ from NO decomposition is not reactive towards $\mathrm{H}_{2}$. Addition of $\mathrm{H}_{2}$ pulse into $\mathrm{NO}$ at $673 \mathrm{~K}$ also resulted in different responses for $\mathrm{Cu}^{2+}(\mathrm{NO})$ and bridged $\mathrm{Cu}^{2+}\left(\mathrm{NO}_{3}{ }^{\circ}\right)$ species suggesting the presence of two different $\mathrm{Cu}^{2+}$ sites during NO decomposition. $\mathrm{O}_{2}$ pulse promotes the formation of bridged nitrato species and mildly affects NO decomposition; does not affect the adsorbate or reactant/product concentration under $\mathrm{N}_{2} \mathrm{O}$ decomposition conditions. $\mathrm{CO}$ pulse into $\mathrm{N}_{2} \mathrm{O}$ promoted the formation/desorption of two types of $\mathrm{O}_{2}$ compared to one type of $\mathrm{O}_{2}$ during $\mathrm{NO}$ decomposition. Both $\mathrm{NO}$ and $\mathrm{N}_{2} \mathrm{O}$ decomposition pathways follow the redox pathway, i.e. inter-conversion between $\mathrm{Cu}^{+}$and $\mathrm{Cu}^{2+}$, with the redox cycle occurring more rapidly during $\mathrm{N}_{2} \mathrm{O}$ decomposition than during $\mathrm{NO}$ decomposition. $\mathrm{Cu}^{+}(\mathrm{NO})$ profile follows the gaseous $\mathrm{N}_{2} \mathrm{O}$ profile during $\mathrm{NO}$ decomposition suggesting that it $\left(\mathrm{Cu}^{+}(\mathrm{NO})\right.$ ) maybe a precursor for $\mathrm{NO}$ decomposition to $\mathrm{N}_{2} \mathrm{O}$.
\end{abstract}




\section{INTRODUCTION}

Catalytic NO decomposition has been a subject of extensive studies due to its promise for the effective control of $\mathrm{NO}_{x}$ emission (1-4). The attention has recently expanded to $\mathrm{N}_{2} \mathrm{O}$ decomposition due to the fact that nitrous oxide $\left(\mathrm{N}_{2} \mathrm{O}\right)$ is not only a byproduct of NO decomposition and reduction but also an effective green-house gas and ozone destruction reagent (5-8). Cu-ZSM-5 has so far been shown to exhibit the highest activity for NO decomposition and high $\mathrm{N}_{2} \mathrm{O}$ decomposition activity (8-18). Despite its effectiveness, for the $\mathrm{NO}$ and $\mathrm{N}_{2} \mathrm{O}$ decomposition reaction, Cu-ZSM-5 is not resistant to oxidants, water or sulfur (19). In the present study, we have focused on the fundamental understanding of the NO and $\mathrm{N}_{2} \mathrm{O}$ decomposition reaction on Cu-ZSM-5 so that knowledge of active sites and adsorbates can be utilized to design and synthesize novel catalysts that would exhibit not only high activity but also deactivation resistance.

Extensive infrared studies have reported that $\mathrm{Cu}^{+}(\mathrm{NO})\left(1814 \mathrm{~cm}^{-1}\right), \mathrm{Cu}^{2+}(\mathrm{NO})\left(1910 \mathrm{~cm}^{-}\right.$ $\left.{ }^{1}\right), \mathrm{Cu}^{2+} \mathrm{O}^{-}(\mathrm{NO})\left(1890-1900 \mathrm{~cm}^{-1}\right), \mathrm{NO}^{+}\left(2123 \mathrm{~cm}^{-1}\right)$, and bridging and chelating $\mathrm{Cu}^{2+}\left(\mathrm{NO}_{3}{ }^{-}\right)$ $\left(1623,1610\right.$, and $\left.1565 \mathrm{~cm}^{-1}\right)$ are the major adsorbates observed during NO decomposition at 77 $673 \mathrm{~K}(9-18,20-22)$. Our recent transient, site-poisoning, and promotion studies have revealed that (i) $\mathrm{NO}^{+}$is a spectator, (ii) $\mathrm{N}_{2}$ and $\mathrm{O}_{2}$ formation proceeds through separate rate-limiting steps, and (iii) inhibition of adsorbed $\mathrm{O}$ migration is the major deactivation pathway for $\mathrm{O}_{2}$ formation (23). These studies further suggested $\mathrm{Cu}^{+}$as active sites and $\mathrm{Cu}^{+}(\mathrm{NO})$ and $\mathrm{Cu}^{2+}\left(\mathrm{NO}_{3}{ }^{-}\right)$as active adsorbates, participated in the catalytic cycle of NO decomposition.

In contrast to extensive studies of $\mathrm{NO}$ decomposition, no infrared study on $\mathrm{N}_{2} \mathrm{O}$ decomposition over Cu-ZSM-5 has been reported. Little is known about the $\mathrm{N}_{2} \mathrm{O}$ decomposition mechanism and its relation to NO decomposition. The current study investigates the 
mechanisms of both $\mathrm{NO}$ and $\mathrm{N}_{2} \mathrm{O}$ decomposition over $\mathrm{Cu}-\mathrm{ZSM}-5$ by probing its active sites and adsorbates with pulsing $\mathrm{H}_{2}, \mathrm{O}_{2}$, and $\mathrm{CO}$ into the reaction systems. Since both $\mathrm{NO}$ and $\mathrm{N}_{2} \mathrm{O}$ decomposition reactions are redox reactions which may involve both $\mathrm{Cu}^{+}$and $\mathrm{Cu}^{2+}$ sites on $\mathrm{Cu}$ ZSM-5, probing the reactions with a reductant (i.e., $\mathrm{H}_{2}$ or $\mathrm{CO}$ ) is expected to reduce $\mathrm{Cu}^{2+}$ to $\mathrm{Cu}^{+}$; probing with an oxidant is expect to oxidize $\mathrm{Cu}^{+}$to $\mathrm{Cu}^{2+}$, resulting in perturbation of adsorbate concentration and production formation process. In addition, the reductants and oxidants are also expected to react with some of the adsorbates. Changes in adsorbate as well as reactant/product concentrations were monitored by infrared and mass spectroscopy, respectively. This study revealed the nature of catalytic cycles for $\mathrm{NO}$ and $\mathrm{N}_{2} \mathrm{O}$ decomposition, distinguished the sites for the $\mathrm{NO}$ and $\mathrm{N}_{2} \mathrm{O}$ decomposition reaction, examined the role of oxidizing and reducing reagents in the reactions. 


\section{EXPERIMENTAL}

\section{Catalyst Preparation}

Cu-ZSM-5-523, with a $523 \%$ copper exchange, was prepared by the repeated ion exchange of Cu-ZSM-5-83 (83 \% copper exchange), which was prepared by Johnson Matthey and supplied by the Catalyst bank of Sandia National Laboratories. The percentage copper exchange is defined as the molar ratio of the amount of $\mathrm{Cu}$ to that of $\mathrm{Al}$ multiplied by $2(\% \mathrm{Cu}$ exchange $=2$ (moles of $\mathrm{Cu} /$ moles of $\mathrm{Al})$ ) (19). Cu-ZSM-5-83 was added to a $0.004 \mathrm{M}$ copper acetate solution at a pH of 7 and stirred for $24 \mathrm{~h}$. The solution was filtered and the solid deposited on the filter paper was washed with distilled water and dried in air at $373 \mathrm{~K}$ for $24 \mathrm{~h}$. Inductively coupled plasma emission spectroscopy (Galbraith Laboratories, Knoxville) determined $\mathrm{Si} / \mathrm{Al}$ to be 25 and $\mathrm{Cu} / \mathrm{Al}$ of 2.615 in $\mathrm{Cu}-\mathrm{ZSM}-5-523$.

\section{Reactor System}

The catalyst, pressed in the form of a self-supporting thin pellet of $15-25 \mathrm{mg}$, was placed in the in situ infrared (IR) reactor cell directly in the path of the IR beam (24). Three additional catalyst pellets were crushed into flakes and placed in the reactor outlet that was in close vicinity of the self-supporting pellet. A Magna ${ }^{\mathrm{TM}}$ (Nicolet Instruments) 550 Fourier transform IR spectrometer (FTIR) recorded the IR spectra and a Pfeiffer Prisma ${ }^{\text {TM }}$ QMG 200 (Pfeiffer Vacuum Technology) mass spectrometer (MS) recorded the changes in the concentration of the reactants and products during the study. 
Temperature Programmed Reaction (TPR) Studies

Temperature programmed reaction (TPR) studies involved the exposure of Cu-ZSM-5523 to a $5 \%$ NO in He stream $\left(50 \mathrm{~cm}^{3} / \mathrm{min}\right)$ at $373 \mathrm{~K}$ followed by heating the reactor from $373 \mathrm{~K}$ to $743 \mathrm{~K}$ at a heating rate of $10 \mathrm{~K} / \mathrm{min}$. The Cu-ZSM-5-523 catalyst, active for pulse NO and $\mathrm{N}_{2} \mathrm{O}$ decomposition, was also exposed to a $5 \% \mathrm{~N}_{2} \mathrm{O}$ in He stream $\left(50 \mathrm{~cm}^{3} / \mathrm{min}\right)$ at $333 \mathrm{~K}$ and was subjected to a temperature increase (TPR) from 333 to $773 \mathrm{~K}$ at $10 \mathrm{~K} / \mathrm{min}$. The IR and MS monitored the changes in the adsorbate and gaseous effluent concentration during the TPR studies, respectively.

\section{Transient Reduction and Oxidation Pulse Studies}

$1 \mathrm{~cm}^{3}$ of $\mathrm{H}_{2}, \mathrm{O}_{2}$, and $\mathrm{CO}$ were separately pulsed with a 6-port gas chromatograph (GC) injection valve into a steady-state 5\% NO in He flow over Cu-ZSM-5-523 at 673 and $723 \mathrm{~K}$. Introduction of the $\mathrm{H}_{2}$ and $\mathrm{CO}$ (well-known reductants) pulses exposed Cu-ZSM-5-523 to a reducing environment for a short period of time while the $\mathrm{O}_{2}$ pulse exposed the catalyst to an oxidizing environment for a short period of time under NO reaction conditions. The $\mathrm{H}_{2}, \mathrm{O}_{2}$, and $\mathrm{CO}$ pulses were also injected into a $5 \% \mathrm{~N}_{2} \mathrm{O}$ in He flow over Cu-ZSM-5-523 at 673 and $723 \mathrm{~K}$. The $\mathrm{H}_{2}, \mathrm{O}_{2}$, and $\mathrm{CO}$ pulse studies into $\mathrm{NO}$ and $\mathrm{N}_{2} \mathrm{O}$ involved the introduction of three separate 1 $\mathrm{cm}^{3}$ pulses of $\mathrm{H}_{2} / \mathrm{O}_{2} / \mathrm{CO}$ into the $5 \% \mathrm{NO}$ and $5 \% \mathrm{~N}_{2} \mathrm{O}$ stream at $673 \mathrm{~K}$ over Cu-ZSM-5-523. Each of the three pulses resulted in similar changes in the adsorbate intensity and MS profiles of gaseous reactants and products, which were reproducible. The IR and MS monitored the changes in the adsorbate and reactor effluent during the $\mathrm{H}_{2}, \mathrm{O}_{2}$, and $\mathrm{CO}$ pulse study under NO and $\mathrm{N}_{2} \mathrm{O}$ reaction conditions, respectively. 
Prior to the TPR studies, IR spectra of each of the catalyst samples were collected in flowing He at each specific temperature. These spectra were denoted as the background spectra. The background spectrum at the specific temperature was subtracted from the IR spectrum collected at the corresponding temperature during the TPR studies. The resulting IR spectra; shown in this study, hence do not have any contribution from the characteristic vibrations of the catalyst sample or from background spectrum changes with temperature. The background spectra and the spectra obtained during the TPR studies were collected by co-adding 32 scans which were collected in $4 \mathrm{sec}$. The spectrum at each temperature during the TPR was collected within a $1 \mathrm{~K}$ variation in the temperature. Hence, the co-added spectrum collected during the TPR represents the average change in adsorbate intensity during a $1 \mathrm{~K}$ increase in temperature.

The MS profiles of the gaseous species were distinguished from each other by the $\mathrm{m} / \mathrm{e}$ ratios: $\mathrm{m} / \mathrm{e}=30$ for $\mathrm{NO}, \mathrm{m} / \mathrm{e}=28$ for $\mathrm{N}_{2}, \mathrm{~m} / \mathrm{e}=32$ for $\mathrm{O}_{2}, \mathrm{~m} / \mathrm{e}=44$ for $\mathrm{N}_{2} \mathrm{O}, \mathrm{m} / \mathrm{e}=46$ for $\mathrm{NO}_{2}$, $\mathrm{m} / \mathrm{e}=12$ for $\mathrm{CO}$, and $\mathrm{m} / \mathrm{e}=22$ for $\mathrm{CO}_{2}$. The contributions of the $\mathrm{N}_{2} \mathrm{O}$ fragment to $\mathrm{NO}(\mathrm{m} / \mathrm{e}=30)$ and $\mathrm{N}_{2}(\mathrm{~m} / \mathrm{e}=28)$ profiles and that of $\mathrm{NO}_{2}$ to $\mathrm{NO}(\mathrm{m} / \mathrm{e}=30)$ were accounted for in the present study. Calibration factors for each gaseous species were obtained by pulsing known amounts of the gases into the MS. The calculated calibrated factors were utilized for converting the MS intensities of the reactants and products to their respective molar rates. 


\section{RESULTS}

$\mathrm{NO}$ and $\mathrm{N}_{2} \mathrm{OTPR}$

Figure 1 shows the IR spectra (fig. 1(a)) and the change in the concentrations of reactor effluent (fig. 1(b)) obtained during the $5 \%$ NO TPR from 373 to $773 \mathrm{~K}(10 \mathrm{~K} / \mathrm{min})$ over $\mathrm{Cu}$ ZSM-5-523. Flowing 5\% NO at $373 \mathrm{~K}$ produced adsorbed $\mathrm{N}_{2}$ at $2158 \mathrm{~cm}^{-1}, \mathrm{Cu}^{2+}(\mathrm{NO})$ at 1910 $\mathrm{cm}^{-1}$, bridging $\mathrm{Cu}^{2+}\left(\mathrm{NO}_{3}^{-}\right)$at 1627 and $1612 \mathrm{~cm}^{-1}$, and chelating $\mathrm{Cu}^{2+}\left(\mathrm{NO}_{3}^{-}\right)$at $1567 \mathrm{~cm}^{-1}$ as shown in Fig. 1(a). Increase in temperature from 373 to $743 \mathrm{~K}$ led to changes in both the adsorbate and reactor effluent concentrations: $\mathrm{NO}$ decomposition to $\mathrm{N}_{2} \mathrm{O}$ and $\mathrm{O}_{2}$ commenced at $473 \mathrm{~K}$ where $\mathrm{Cu}^{2+}(\mathrm{NO})$ showed a substantial drop in its $\mathrm{IR}$ intensity, $\mathrm{Cu}^{2+}\left(\mathrm{NO}_{3}{ }^{-}\right)$exhibited a slight decrease in its intensity, and $\mathrm{Cu}^{+}(\mathrm{NO})$ emerged. $\mathrm{The}^{+}(\mathrm{NO})$ intensity paralleled the rate of $\mathrm{N}_{2} \mathrm{O}$ formation with the depletion of $\mathrm{Cu}^{+}(\mathrm{NO})$ coinciding with that of $\mathrm{N}_{2} \mathrm{O}$, suggesting that $\mathrm{NO}$ adsorbed on $\mathrm{Cu}^{+}$may serve as a precursor for $\mathrm{N}_{2} \mathrm{O}$ formation. Selective NO decomposition to $\mathrm{N}_{2}$ and $\mathrm{O}_{2}$ occurred at $753 \mathrm{~K}$ where no IR observable adsorbates were detected, indicating that the rate of desorption of adsorbates and the rate of product formation from adsorbates are significantly higher than adsorbate formation rate.

The IR spectra and MS profiles of the reactor effluent collected during the $5 \% \mathrm{~N}_{2} \mathrm{O}$ TPR over Cu-ZSM-5-523 from 333 to $773 \mathrm{~K}$ are shown in Fig. 2. Exposure of Cu-ZSM-5-523 to 5\% $\mathrm{N}_{2} \mathrm{O}$ at $333 \mathrm{~K}$ led to the appearance of prominent IR bands at 2287,2241 , and $2216 \mathrm{~cm}^{-1}$ and a weak band at $1624 \mathrm{~cm}^{-1}$. The assignment of the bands in the $2200-2300 \mathrm{~cm}^{-1}$ region has not been established unambiguously on Cu-ZSM-5 while the $1624 \mathrm{~cm}^{-1}$ band has previously assigned to the bridging $\mathrm{Cu}^{2+}\left(\mathrm{NO}_{3}{ }^{-}\right)$species based on the NO adsorption studies on Cu-ZSM-5 (22-23). The present study attempts to assign bands in the $2200-2300 \mathrm{~cm}^{-1}$ region based on the observations 
reported during $\mathrm{N}_{2} \mathrm{O}$ adsorption studies on various transition metal zeolites, metal oxides, and metals. The high electron density at the terminal $\mathrm{N}$ and $\mathrm{O}$ atoms allows $\mathrm{N}_{2} \mathrm{O}$ to bond to the zeolites, metal oxides, and metals via either the $\mathrm{N}$ or $\mathrm{O}$ end. The band at $2224 \mathrm{~cm}^{-1}$ represents $\mathrm{N}$ $\mathrm{N}$ vibration and the $1285 \mathrm{~cm}^{-1}$ band signifies the $\mathrm{N}-\mathrm{O}$ vibration for $\mathrm{N}_{2} \mathrm{O}$ in the gas phase. $\mathrm{N}_{2} \mathrm{O}$ adsorbed on $\mathrm{ZnO}$ and $\mathrm{ZrO}_{2}$ via $\mathrm{O}$ at 2237-2242 and 1233-1255 $\mathrm{cm}^{-1}$ (25-30); on $\alpha$-chromia surface via $\mathrm{N}$ at 2305 and $1339 \mathrm{~cm}^{-1}$ and via $\mathrm{O}$ at 2238 and $1237 \mathrm{~cm}^{-1}$ (31); on NaA, CoA, NiA, and $\mathrm{CuA}$ via $\mathrm{N}$ at $2258-2272$ and $1282-1304 \mathrm{~cm}^{-1}$ and via $\mathrm{O}$ at $2223-2250$ and $1240-1282 \mathrm{~cm}^{-1}$ (32). It has also been reported that $\mathrm{N}_{2} \mathrm{O}$ bonds to the $\mathrm{Cu}$ (I) cations on $\mathrm{CuA}$ via $\mathrm{N}$ at $2230-2250$ and $1289 \mathrm{~cm}^{-1}$ and via $\mathrm{O}$ at $2223 \mathrm{~cm}^{-1}$ and $1282 \mathrm{~cm}^{-1}$ (32). Hence, as a general rule, bands observed in the 2224-2260 and $1200-1285 \mathrm{~cm}^{-1}$ (lower than $1285 \mathrm{~cm}^{-1}$ ) regions have been assigned to $\mathrm{N}_{2} \mathrm{O}$ adsorbed via $\mathrm{O}$ while the bands in the $2224-2300$ and $1285-1350 \mathrm{~cm}^{-1}$ regions have been assigned to $\mathrm{N}_{2} \mathrm{O}$ adsorbed via $\mathrm{N}$. Based on these studies the band observed in the present study at $2287 \mathrm{~cm}^{-1}$ is assigned to the $\mathrm{N}$-bound $\mathrm{N}_{2} \mathrm{O}$ on $\mathrm{Cu}^{+}\left(\mathrm{Cu}^{+}-\mathrm{N}_{2} \mathrm{O}\right)$ and the $2241 \mathrm{~cm}^{-1}$ band to the O-bound $\mathrm{N}_{2} \mathrm{O}$ on $\mathrm{Cu}^{+}\left(\mathrm{Cu}^{+}-\mathrm{ON}_{2}\right)$. The corresponding $\mathrm{N}-\mathrm{O}$ vibrations in the lower frequency region of $1235-1310 \mathrm{~cm}^{-1}$ could not be observed in the present study as they were overlapped by the presence of gaseous $\mathrm{N}_{2} \mathrm{O}$ bands in the same region and were lower in intensity compared to the N-N vibrations.

Temperature increase from 333 to $423 \mathrm{~K}$ depleted a majority of the $\mathrm{Cu}^{+}-\mathrm{N}_{2} \mathrm{O}$ species at $2287 \mathrm{~cm}^{-1}$ and led to an increase in the bridging $\mathrm{Cu}^{2+}\left(\mathrm{NO}_{3}{ }^{\circ}\right)$ species at $1623 \mathrm{~cm}^{-1}$ while there was no change in the concentration of the gaseous reactants and products. Further temperature increase led to a decrease and eventual depletion of $\mathrm{Cu}^{+}-\mathrm{N}_{2} \mathrm{O}$ and $\mathrm{Cu}^{+}-\mathrm{ON}_{2}$ at $573 \mathrm{~K}$, formation of adsorbed $\mathrm{N}_{2}$ at $473 \mathrm{~K}$ and depletion at $623 \mathrm{~K}$, start of $\mathrm{N}_{2} \mathrm{O}$ decomposition and $\mathrm{N}_{2}$ formation at $573 \mathrm{~K}$, and start of $\mathrm{O}_{2}$ formation at $643 \mathrm{~K}$. High rate of $\mathrm{N}_{2} \mathrm{O}$ decomposition were achieved at 
$773 \mathrm{~K}$ where no IR observable adsorbates were detected. The $\mathrm{N}_{2} \mathrm{O}$ TPR results have for the first time showed that $\mathrm{N}_{2} \mathrm{O}$ adsorbs on $\mathrm{Cu}-\mathrm{ZSM}-5$ via both $\mathrm{N}$ and $\mathrm{O}$ as $\mathrm{Cu}^{+}-\mathrm{N}_{2} \mathrm{O}$ and $\mathrm{Cu}^{+}-\mathrm{ON}_{2}$ as well as a bridging $\mathrm{Cu}^{2+}\left(\mathrm{NO}_{3}{ }^{-}\right)$species at $333 \mathrm{~K}$ and have also confirmed that $\mathrm{N}_{2} \mathrm{O}$ starts to decompose to $\mathrm{N}_{2}$ and $\mathrm{O}_{2}$ at $573 \mathrm{~K}$ and reaches a conversion of $100 \%$ at $773 \mathrm{~K}$ over Cu-ZSM-5.

The TPR results show that Cu-ZSM-5-523 exhibits a higher decomposition activity for $\mathrm{N}_{2} \mathrm{O}$ than $\mathrm{NO} ; \mathrm{N}_{2} \mathrm{O}$ decomposition during TPR produces greater amounts of $\mathrm{N}_{2}$ and $\mathrm{O}_{2}$ compared to NO decomposition in the same temperature range; $\mathrm{O}_{2}$ desorption $(523 \mathrm{~K})$ starts at a lower temperature during $\mathrm{NO}$ decomposition compared to that of $\mathrm{N}_{2} \mathrm{O}(643 \mathrm{~K})$. The different $\mathrm{O}_{2}$ desorption temperatures suggest that different forms of adsorbed $\mathrm{O}$ were produced from NO and $\mathrm{N} 2 \mathrm{O}$ adsorption and surface reactions.

\section{$\mathrm{H}_{2}$ Pulse Studies}

Figures 3 and 4 show the IR spectra, MS profiles of gaseous reactants and products, and adsorbate intensity profiles collected during the first $1 \mathrm{~cm}^{3}$ of $\mathrm{H}_{2}$ pulse into a $5 \% \mathrm{NO}$ in $\mathrm{He}$ stream over Cu-ZSM-5-523 at $673 \mathrm{~K}$. It should be noted that the IR spectra during the pulse were collected every $3.6 \mathrm{sec}$ and the IR intensity profiles of the adsorbates during the entire duration of the pulse are plotted in Fig. 4. However, spectra shown in Fig. 3 do not represent all the collected spectra but illustrate the select few showing the prominent changes during the pulse switch. Exposure of Cu-ZSM-5-523 to $5 \% \mathrm{NO}$ at $673 \mathrm{~K}$, prior to the $\mathrm{H}_{2}$ pulse, led to the formation of bridging and chelating $\mathrm{Cu}^{2+}\left(\mathrm{NO}_{3}{ }^{-}\right)$at 1624 and $1565 \mathrm{~cm}^{-1}, \mathrm{Cu}^{+}(\mathrm{NO})$ at $1814 \mathrm{~cm}^{-1}$, $\mathrm{Cu}^{2+}(\mathrm{NO})$ at $1910 \mathrm{~cm}^{-1}$, and adsorbed $\mathrm{NO}^{+}$at $2123 \mathrm{~cm}^{-1}$ as shown in Fig. 3. Introduction of 1

$\mathrm{cm}^{3}$ of $\mathrm{H}_{2}$ (a) decreased $\mathrm{Cu}^{+}(\mathrm{NO}), \mathrm{Cu}^{2+}(\mathrm{NO})$, bridging $\mathrm{Cu}^{2+}\left(\mathrm{NO}_{3}{ }^{-}\right)$, and adsorbed $\mathrm{NO}^{+}$, (b) increased NO conversion and $\mathrm{N}_{2}, \mathrm{O}_{2}$, and $\mathrm{N}_{2} \mathrm{O}$ formation, and (c) led to the formation of $\mathrm{H}_{2} \mathrm{O}$ 
(gas) at $3511 \mathrm{~cm}^{-1}$ (33) and adsorbed $\mathrm{NH}_{3}$ species at 3360 and $3288 \mathrm{~cm}^{-1}$. The adsorbed $\mathrm{NH}_{3}$ species at 3360 and $3288 \mathrm{~cm}^{-1}$ can be assigned to $\mathrm{NH}_{3}$ bound to $\mathrm{Cu}$ based on the earlier reported IR spectra of $\mathrm{NH}_{3}$ species bound to various $\mathrm{Cu}$ complexes (33). Figure 4 shows that the initial decrease of all the NO adsorbate species and gaseous NO was followed by an increase in $\mathrm{Cu}^{+}(\mathrm{NO})$ and $\mathrm{N}_{2}, \mathrm{~N}_{2} \mathrm{O}$, and $\mathrm{O}_{2}$ formation during the continued decrease of $\mathrm{Cu}^{2+}(\mathrm{NO})$, bridging $\mathrm{Cu}^{2+}\left(\mathrm{NO}_{3}{ }^{-}\right)$, and $\mathrm{NO}^{+}$. The increase in $\mathrm{Cu}^{+}(\mathrm{NO})$, to an intensity higher than that prior to the $\mathrm{H}_{2}$ pulse, accompanied with a decrease in the intensity of the $\mathrm{Cu}^{2+}$ species $\left(\mathrm{Cu}^{2+}(\mathrm{NO})\right.$ and $\mathrm{Cu}^{2+}$ nitrate) reflects an increase in the number of $\mathrm{Cu}^{+}$sites which may be promoting NO conversion, and $\mathrm{N}_{2}, \mathrm{O}_{2}$, and $\mathrm{N}_{2} \mathrm{O}$ formation. The adsorbate and reactant/product concentrations returned to their respective original intensities as the pulsed $\mathrm{H}_{2}$ exited the reactor cell.

The IR spectra in Figs. 3 and 4 also indicate a sharp increase and decrease of $\mathrm{H}_{2} \mathrm{O}$ (gas) while the MS profiles showed the gaseous $\mathrm{H}_{2} \mathrm{O}$ lagging behind the rest of the gaseous species significantly. The lag in the MS profile could be a result of the delay of $\mathrm{H}_{2} \mathrm{O}$ (gas) in entering the MS analysis chamber from the IR cell due to adsorption/desorption of $\mathrm{H}_{2} \mathrm{O}$ on the walls of reactor system lines entering the MS. The role of $\mathrm{H}_{2}$ in NO decomposition can be summarized as causing the reduction of $\mathrm{Cu}^{2+}\left(\mathrm{NO}_{3}{ }^{-}\right)$and $\mathrm{Cu}^{2+}(\mathrm{NO})$ to $\mathrm{Cu}^{+}$and $\mathrm{NH}_{3}$ and $\mathrm{H} 2 \mathrm{O}$, promotion of $\mathrm{O}_{2}$ desorption and formation, and an increase in the number of $\mathrm{Cu}$ sites leading to increases in NO decomposition rate. The $\mathrm{H}_{2}$ pulse results also reveal that the $\mathrm{Cu}^{2+}$ for $\mathrm{Cu}^{2+}(\mathrm{NO})$ is different from that of $\mathrm{Cu}^{2+}\left(\mathrm{NO}_{3}{ }^{-}\right)$as they are affected to a different extent by $\mathrm{H}_{2}$. The $\mathrm{Cu}^{+}-\mathrm{NO}$ species still parallels $\mathrm{N}_{2} \mathrm{O}$ formation similar to that observed during NO TPR.

The first $1 \mathrm{~cm}^{3}$ of $\mathrm{H}_{2}$ pulse into a $5 \% \mathrm{~N}_{2} \mathrm{O}$ stream over Cu-ZSM-5-523 led to changes in the IR intensities of the adsorbate species as well as MS profiles of the gaseous reactants and products as shown in Figs. 5 and 6. Prior to the $\mathrm{H}_{2}$ pulse, the $5 \% \mathrm{~N}_{2} \mathrm{O}$ flow over Cu-ZSM-5-523 
produced gaseous $\mathrm{N}_{2} \mathrm{O}$ at $2250 \mathrm{~cm}^{-1}$ and bridging and chelating $\mathrm{Cu}^{2+}\left(\mathrm{NO}_{3}{ }^{-}\right)$at 1624 and 1565 $\mathrm{cm}^{-1}$ as shown in Fig. 5. Pulsing $1 \mathrm{~cm}^{3}$ of $\mathrm{H}_{2}$ led to the complete depletion of bridging and chelating $\mathrm{Cu}^{2+}\left(\mathrm{NO}_{3}{ }^{\circ}\right)$, formation of adsorbed $-\mathrm{OH}$ species at 3629 and $3583 \mathrm{~cm}^{-1}(34,35)$, increase in gaseous NO conversion and $\mathrm{N}_{2}$ formation, and decrease in $\mathrm{O}_{2}$ formation. The adsorbed $-\mathrm{OH}$ species $\left(3629\right.$ and $3583 \mathrm{~cm}^{-1}$ ) reached their maxima at two separate instances during the $\mathrm{H}_{2}$ pulse as shown in Fig. 6 (e). Gaseous $\mathrm{H}_{2} \mathrm{O}$ also exhibited two maxima similar to the $-\mathrm{OH}$ species (Fig. 6(b)). Careful examination of lead/lag relationship between $\mathrm{Cu}^{2+}\left(\mathrm{NO}_{3}{ }^{-}\right)$, $\mathrm{NO}, \mathrm{O}_{2}$, and $-\mathrm{OH}$ profiles suggests that the first $\mathrm{OH}$ peak in Fig $6(\mathrm{e})$ is due to the reaction of $\mathrm{Cu}^{2+}\left(\mathrm{NO}_{3}{ }^{-}\right)$with adsorbed hydrogen and the second is due to the reaction of all the combined $\mathrm{O}$ from NO and ZSM-5 with adsorbed $\mathrm{H}_{2}$. The presence of $\mathrm{H}_{2}$ also inhibits the recombination of the adsorbed $\mathrm{O}$ species to form $\mathrm{O}_{2}$ as seen by the decrease in $\mathrm{O}_{2}$ formation in Fig. 6a. The adsorbed $\mathrm{O}$ species instead adsorb $\mathrm{H}$ to form $\mathrm{Cu}^{+}-\mathrm{OH}$ species at $3629 \mathrm{~cm}^{-1}$ (34). The formation of $\mathrm{Cu}^{+}-\mathrm{OH}$ also prevents the re-oxidation of $\mathrm{Cu}^{+}$to $\mathrm{Cu}^{2+}$ sites inhibiting the formation of the bridging and chelating $\mathrm{Cu}^{2+}\left(\mathrm{NO}_{3}{ }^{\circ}\right)$ species. As the pulsed $\mathrm{H}_{2}$ exited the reactor, the $-\mathrm{OH}$ species completely disappeared while the bridging and chelating $\mathrm{Cu}^{2+}\left(\mathrm{NO}_{3}{ }^{-}\right)$and all the gaseous reactants/products returned to their original concentrations.

The most obvious role of $\mathrm{H}_{2}$ in both $\mathrm{NO}$ and $\mathrm{N}_{2} \mathrm{O}$ decomposition is the reduction of $\mathrm{Cu}^{2+}$ to $\mathrm{Cu}^{+}$and promotion of $\mathrm{N}_{2}$ formation. The distinction in the effect of $\mathrm{H}_{2}$ on the product formation is the difference in the reactivity of adsorbed oxygen produced from these two reactions. Oxygen from $\mathrm{NO}$ tends to undergo desorption to produce gaseous $\mathrm{O}_{2}$ while oxygen from $\mathrm{N}_{2} \mathrm{O}$ tends to react with adsorbed $\mathrm{H}_{2}$ to produce $\mathrm{H}_{2} \mathrm{O}$. The precursor for $\mathrm{H}_{2} \mathrm{O}$ formation involves the adsorbed $-\mathrm{OH}$ at $3583 \mathrm{~cm}^{-1}$ during $\mathrm{N}_{2} \mathrm{O}$ decomposition and adsorbed $\mathrm{H}_{2} \mathrm{O}$ at 3511 $\mathrm{cm}^{-1}$ for NO decomposition. 


\section{$\mathrm{O}_{2}$ Pulse Studies}

Figure 7 and 8 show the IR spectra, change in concentration of reactants and products, and variation in adsorbate intensity collected during the first $1 \mathrm{~cm}^{3}$ of $\mathrm{O}_{2}$ pulse into a $5 \% \mathrm{NO}$ in He stream over Cu-ZSM-5-523 at $673 \mathrm{~K}$. Prior to the $\mathrm{O}_{2}$ pulse, $\mathrm{NO}$ adsorbs as $\mathrm{Cu}^{+}(\mathrm{NO})$ at 1814 $\mathrm{cm}^{-1}, \mathrm{Cu}^{2+}(\mathrm{NO})$ at $1910 \mathrm{~cm}^{-1}$, bridging and chelating $\mathrm{Cu}^{2+}\left(\mathrm{NO}_{3}\right)$ at 1624 and $1565 \mathrm{~cm}^{-1}$, and $\mathrm{NO}^{+}$at $2123 \mathrm{~cm}^{-1}$ as shown in Fig. 7. The adsorbate spectra prior to the $\mathrm{O}_{2}$ pulse were essentially identical to those prior to the $\mathrm{H}_{2}$ pulse as shown in Fig. $3 . \mathrm{O}_{2}$ pulse (a) decreased $\mathrm{Cu}^{+}(\mathrm{NO})$ and $\mathrm{N}_{2} \mathrm{O}$ formation, (b) increased bridging and chelating $\mathrm{Cu}^{2+}\left(\mathrm{NO}_{3}{ }^{-}\right)$, NO conversion, and $\mathrm{NO}_{2}$ formation, and (c) did not affect $\mathrm{Cu}^{2+}(\mathrm{NO}), \mathrm{N}_{2}$ formation, and $\mathrm{NO}^{+}$as shown in Figs. 7 and 8. These observations can be explained by oxidation of adsorbates and surface from $\mathrm{Cu}^{+}$to $\mathrm{Cu}^{2+}$. Decrease in $\mathrm{Cu}^{+}(\mathrm{NO})$ with $\mathrm{N}_{2} \mathrm{O}$ further supports the postulation that $\mathrm{Cu}^{+}(\mathrm{NO})$ could serve as a precursor for $\mathrm{N}_{2} \mathrm{O}$ formation. Furthermore, the mirror image intensity profiles of $\mathrm{Cu}^{+}(\mathrm{NO})$ and bridging and chelating $\mathrm{Cu}^{2+}\left(\mathrm{NO}_{3}{ }^{-}\right)$reflects the oxidation of $\mathrm{Cu}^{+}$'sites to $\mathrm{Cu}^{2+}$ leading to the conversion of part of $\mathrm{Cu}^{+}(\mathrm{NO})$ to bridging and chelating $\mathrm{Cu}^{2+}\left(\mathrm{NO}_{3}{ }^{\circ}\right)$ during $\mathrm{O}_{2}$ addition. The decrease in NO concentration and increase of $\mathrm{NO}_{2}$ is a result of the reaction of $\mathrm{NO}$ with $\mathrm{O}_{2}$ to produce $\mathrm{NO}_{2}$ as well as a consequence of the co-adsorption of $\mathrm{NO}$ and $\mathrm{O}_{2}$ to produce the $\mathrm{Cu}^{2+}\left(\mathrm{NO}_{3}{ }^{-}\right)$species.

In contrast to the pronounced effect of $\mathrm{O}_{2}$ on $\mathrm{NO}$ decomposition, the $\mathrm{O}_{2}$ pulse into $5 \%$ $\mathrm{N}_{2} \mathrm{O}$ at $673 \mathrm{~K}$ did not cause any variation in adsorbate and product concentration. The lack of changes in the adsorbate and product concentration can be attributed to the lack of interaction between the adsorbed $\mathrm{O}$ from $\mathrm{O}_{2}$ and the adsorbed $\mathrm{O}$ species from $\mathrm{N}_{2} \mathrm{O}$ decomposition. 
CO Pulse Studies

Figures 9 and 10 show the IR spectra, MS profiles of reactants and products, and the variation of adsorbate intensities with time collected during the first $1 \mathrm{~cm}^{3}$ of $\mathrm{CO}$ pulse into a $5 \%$ NO in He stream over Cu-ZSM-5-523 at $673 \mathrm{~K}$. CO pulse into $5 \%$ NO produced changes in both the adsorbate and gaseous reactants and products concentrations. $\mathrm{CO}$ entry depleted bridging and chelating $\mathrm{Cu}^{2+}\left(\mathrm{NO}_{3}{ }^{-}\right)$; increased $\mathrm{NO}$ conversion and $\mathrm{N}_{2}, \mathrm{O}_{2}$, and $\mathrm{N}_{2} \mathrm{O}$ formation; caused the formation of $\mathrm{CO}_{2}$ at $2345 \mathrm{~cm}^{-1}, \mathrm{Cu}^{+}(\mathrm{CO})$ at $2157 \mathrm{~cm}^{-1}, \mathrm{Cu}^{+}(\mathrm{CO})_{3}$ at $2192 \mathrm{~cm}^{-1}$, and adsorbed $\mathrm{CO}$ at $2140 \mathrm{~cm}^{-1}(23) . \mathrm{Cu}^{+}(\mathrm{NO})$ initially decreased upon $\mathrm{CO}$ addition but increased to intensity higher than that prior to $\mathrm{CO}$ pulse during the continued decrease of bridging and chelating $\mathrm{Cu}^{2+}\left(\mathrm{NO}_{3}{ }^{-}\right)$. Formation of $\mathrm{Cu}^{+}(\mathrm{CO})$ and $\mathrm{Cu}^{+}(\mathrm{CO})_{3}$ and depletion of $\mathrm{Cu}^{2+}\left(\mathrm{NO}_{3}{ }^{-}\right)$ indicates the occurrence of the reduction of $\mathrm{Cu}^{2+}$ to $\mathrm{Cu}^{+}$; depletion of $\mathrm{Cu}^{2+}\left(\mathrm{NO}_{3}{ }^{-}\right)$and $\mathrm{Cu}^{+}(\mathrm{NO})$ upon $\mathrm{CO}$ entry reflects the reaction of adsorbed nitrato- species with $\mathrm{CO}$; increase in NO conversion and $\mathrm{O}_{2}$ formation during the presence of $\mathrm{Cu}^{+}(\mathrm{CO})$ confirms that $\mathrm{Cu}^{+}$plays a vital role in $\mathrm{NO}$ decomposition. The major roles of $\mathrm{CO}$, a reductant, are to reduce $\mathrm{Cu}^{2+}$ to $\mathrm{Cu}^{+}$increasing NO decomposition, to react with adsorbed nitrato- species on $\mathrm{Cu}^{2+}$ and $\mathrm{Cu}^{+}$, and to adsorb as $\mathrm{Cu}^{+}(\mathrm{CO})$ and $\mathrm{Cu}^{+}(\mathrm{CO})_{3}$.

Figures 11 and 12 show the IR spectra, MS profiles of reactants and products, and the variation of adsorbate intensities with time collected during the first $1 \mathrm{~cm}^{3}$ of $\mathrm{CO}$ pulse into a $5 \%$ $\mathrm{N}_{2} \mathrm{O}$ in He stream over Cu-ZSM-5-523 at $673 \mathrm{~K}$. Pulsing of $1 \mathrm{~cm}^{3}$ of $\mathrm{CO}$ decreased bridging and chelating $\mathrm{Cu}^{2+}\left(\mathrm{NO}_{3}{ }^{-}\right)$, increased $\mathrm{N}_{2} \mathrm{O}$ conversion and $\mathrm{N}_{2}$ and $\mathrm{O}_{2}$ formation, and produced $\mathrm{CO}_{2}$ (gas) at $2350 \mathrm{~cm}^{-1}, \mathrm{Cu}^{+}(\mathrm{CO})$ at $2157 \mathrm{~cm}^{-1}$ and adsorbed $\mathrm{CO}$ at $2140 \mathrm{~cm}^{-1}$ as shown in Figs: 11 and 12. The decrease in bridging and chelating nitrato species combined with the formation of $\mathrm{Cu}^{+}(\mathrm{CO})$ and promotion of $\mathrm{N}_{2}$ and $\mathrm{O}_{2}$ formation suggests that the introduction of $\mathrm{CO}$ reduced the 
$\mathrm{Cu}^{2+}$ sites to $\mathrm{Cu}^{+}$which promotes the $\mathrm{N}_{2} \mathrm{O}$ decomposition and hence $\mathrm{N}_{2}$ and $\mathrm{O}_{2}$ formation. The $\mathrm{O}_{2}$ produced during the $\mathrm{CO}$ pulse exhibited two peaks in concentrations suggesting that the $\mathrm{CO}$ pulse promoted the desorption of two different types of adsorbed $O$ species.

The $\mathrm{CO}$ pulse onto $\mathrm{Cu}-\mathrm{ZSM}-5-523$ at $673 \mathrm{~K}$ promotes $\mathrm{N}_{2}$ and $\mathrm{CO}_{2}$ formation during the $\mathrm{NO}$ and $\mathrm{N}_{2} \mathrm{O}$ decomposition reactions. Under $\mathrm{N}_{2} \mathrm{O}$ decomposition conditions however, $\mathrm{CO}$ addition promoted the desorption of two kinds of adsorbed $\mathrm{O}$ species different from that produced during $\mathrm{NO}$ decomposition. Although the bridging and chelating $\mathrm{Cu}^{2+}\left(\mathrm{NO}_{3}{ }^{-}\right)$are produced via different precursors in $\mathrm{NO}$ and $\mathrm{N}_{2} \mathrm{O}$ decomposition reactions, the introduction of $\mathrm{CO}$ led to the reduction of the $\mathrm{Cu}^{2+}$ sites to $\mathrm{Cu}^{+}$which adsorbed $\mathrm{CO}$ similarly as $\mathrm{Cu}^{+}(\mathrm{CO})$ and adsorbed CO (Figs. 9 and 11).

$\mathrm{N}_{2} \mathrm{O}$ Pulse into $\mathrm{NO}$

Figures 13 and 14 show the IR spectra, MS profiles of the reactants and products, and the variation of adsorbates intensities with time collected during a $1 \mathrm{~cm}^{3}$ of $\mathrm{N}_{2} \mathrm{O}$ pulse into a $5 \% \mathrm{NO}$ stream over Cu-ZSM-5-523 at $673 \mathrm{~K} . \mathrm{N}_{2} \mathrm{O}$ pulse into $5 \% \mathrm{NO}$ led to a decrease in $\mathrm{Cu}^{+}(\mathrm{NO})$ and $\mathrm{NO}^{+}$, increase in bridging and chelating $\mathrm{Cu}^{2+}\left(\mathrm{NO}_{3}{ }^{\circ}\right)$, increase in $\mathrm{N}_{2}$ and $\mathrm{O}_{2}$ formation, and little change in $\mathrm{Cu}^{2+}(\mathrm{NO})$ and gaseous $\mathrm{NO}$ concentration as shown in Figs. 13 and $14 . \mathrm{N}_{2} \mathrm{O}$, being an oxidant, oxidizes the $\mathrm{Cu}^{+}$sites to $\mathrm{Cu}^{2+}$ thus decreasing $\mathrm{Cu}^{+}(\mathrm{NO})$ and increasing bridging and chelating $\mathrm{Cu}^{2+}\left(\mathrm{NO}_{3}{ }^{\circ}\right)$. The increase in bridging and chelating nitrato species is accompanied by a significant increase in $\mathrm{N}_{2}$ and $\mathrm{O}_{2}$ formation but no significant change in NO concentration suggesting that the additional $\mathrm{N}_{2}$ and $\mathrm{O}_{2}$ formed is from the $\mathrm{N}_{2} \mathrm{O}$ decomposition reaction rather than due to promotion of NO decomposition. Hence, the increase in the nitrato adsorbate species may also be due to the combination of $\mathrm{Cu}^{+}$oxidation and $\mathrm{N}_{2} \mathrm{O}$ adsorption. 


\section{DISCUSSION}

\section{$\mathrm{N}_{2} \mathrm{O}$ Decomposition}

The TPR and $\mathrm{H}_{2}, \mathrm{CO}$, and $\mathrm{O}_{2}$ pulse into $\mathrm{N}_{2} \mathrm{O}$ results have shown that the $\mathrm{N}_{2} \mathrm{O}$ decomposition to $\mathrm{N}_{2}$ and $\mathrm{O}_{2}$ over Cu-ZSM-5 occurs in the presence of $\mathrm{Cu}^{+}-\mathrm{N}_{2} \mathrm{O}, \mathrm{Cu}^{+}-\mathrm{ON}_{2}$, and bridging and chelating $\mathrm{Cu}^{2+}\left(\mathrm{NO}_{3}{ }^{-}\right.$) (Figs. 2, 5, 6, 9, 10, 13, and 14). The proposed reaction mechanism for the $\mathrm{N}_{2} \mathrm{O}$ decomposition reaction is illustrated in scheme $\mathrm{A}$.

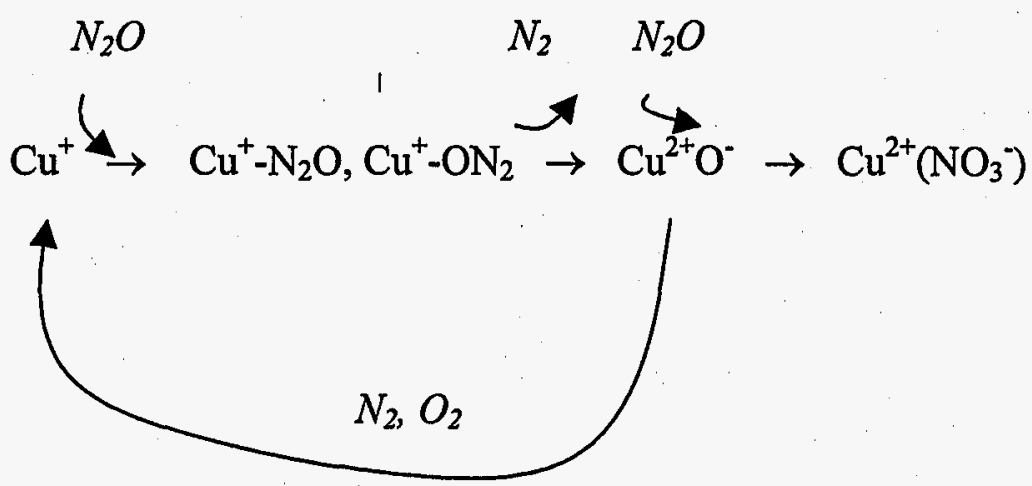

\section{Scheme A}

The $\mathrm{N}_{2} \mathrm{O}$ TPR studies show that prior to the increase in temperature, the $\mathrm{N}_{2} \mathrm{O}$ step switch led to the formation of $\mathrm{Cu}^{+}-\mathrm{N}_{2} \mathrm{O}$ and $\mathrm{Cu}^{+}-\mathrm{ON}_{2}$ as shown in Fig. 2. $\mathrm{N}_{2} \mathrm{O}$ adsorption studies onto $\mathrm{Cu}-$ ZSM-5 at different $\mathrm{N}_{2} \mathrm{O}$ concentrations at $303 \mathrm{~K}$ also confirm the formation of these adsorbate species (35). Based on these results, it is proposed that $\mathrm{N}_{2} \mathrm{O}$ initially adsorbs onto the $\mathrm{Cu}^{+}$sites via $\mathrm{N}$ as $\mathrm{Cu}^{+}-\mathrm{N}_{2} \mathrm{O}$ and via $\mathrm{O}$ as $\mathrm{Cu}^{+}-\mathrm{ON}_{2}$ as indicated. $\mathrm{N}_{2}$ formation occurs when both $\mathrm{Cu}^{+}-\mathrm{N}_{2} \mathrm{O}$ and $\mathrm{Cu}^{+}-\mathrm{ON}_{2}$ rearrange to produce $\mathrm{N}_{2}$ and $\mathrm{Cu}^{2+} \mathrm{O}: \mathrm{N}_{2}$ formation is accompanied by the oxidation of $\mathrm{Cu}^{+}$species to $\mathrm{Cu}^{2+}$ as indicated by the formation of $\mathrm{Cu}^{2+} \mathrm{O}^{-}$species. Evidence for the formation of $\mathrm{Cu}^{2+} \mathrm{O}^{-}$species can be inferred from the $\mathrm{H}_{2}$ pulse results (Figs.5 and 6) that 
show the formation of $\mathrm{Cu}^{2+} \mathrm{OH}$ upon $\mathrm{H}_{2}$ addition suggesting that adsorbed $\mathrm{H}$ interacts with the $\mathrm{Cu}^{2+} \mathrm{O}^{-}$species to produce $\mathrm{Cu}^{2+} \mathrm{OH}$. The path for $\mathrm{O}_{2}$ formation involves the interaction of $\mathrm{Cu}^{2+} \mathrm{O}^{-}$with $\mathrm{N}_{2} \mathrm{O}$ to produce $\mathrm{Cu}^{+}$and $\mathrm{O}_{2}$ as shown. $\mathrm{N}_{2} \mathrm{O}$ plays the role of a reductant by reducing the $\mathrm{Cu}^{2+}$ species to $\mathrm{Cu}^{+}$leading to $\mathrm{O}_{2}$ formation. Thermodynamic calculations based on the quantum chemical and statistical mechanical calculations also indicate that the Gibbs free energy for the reaction $\mathrm{CuO}+\mathrm{N}_{2} \mathrm{O} \rightarrow \mathrm{Cu}^{+}+\mathrm{N}_{2}+\mathrm{O}_{2}$ is $-31.5 \mathrm{kcal} / \mathrm{mol}$ suggesting that this route for $\mathrm{N}_{2}$ and $\mathrm{O}_{2}$ formation is possible $(36,37)$. The formation of bridged and chelating $\mathrm{Cu}^{2+}\left(\mathrm{NO}_{3}{ }^{-}\right)$ in $\mathrm{N}_{2} \mathrm{O}$ decomposition involves the interaction of $\mathrm{Cu}^{2+} \mathrm{O}^{-}$and $\mathrm{Cu}^{+}-\mathrm{N}_{2} \mathrm{O}$ and $\mathrm{Cu}^{+}-\mathrm{ON}_{2}$. This step is not an elementary step and is complex and not very well understood.

The $\mathrm{H}_{2}, \mathrm{O}_{2}$, and $\mathrm{CO}$ pulse into $5 \% \mathrm{~N}_{2} \mathrm{O}$ affect the $\mathrm{N}_{2} \mathrm{O}$ decomposition pathway differently. $\mathrm{H}_{2}$ pulse affects the pathway in two ways: (a) promotes $\mathrm{Cu}^{2+}$ reduction to $\mathrm{Cu}^{+}$and $\mathrm{N}_{2} \mathrm{O}$ decomposition to $\mathrm{N}_{2}$ and (b) inhibits $\mathrm{O}_{2}$ formation. Specifically, the adsorbed $\mathrm{H}$ from $\mathrm{H}_{2}$ pulse interacts with $\mathrm{Cu}^{2+} \mathrm{O}^{-}$to produce $\mathrm{Cu}^{2+}-\mathrm{OH}$, which later combines with another $\mathrm{H}$ to produce $\mathrm{Cu}^{+}$and $\mathrm{H}_{2} \mathrm{O}$. This process not only creates more $\mathrm{Cu}^{+}$sites on which $\mathrm{N}_{2} \mathrm{O}$ can adsorb to produce $\mathrm{N}_{2}$ but also depletes $\mathrm{Cu}^{2+} \mathrm{O}^{-}$that is in the route of $\mathrm{O}_{2}$ formation. Hence, $\mathrm{O}_{2}$ formation is inhibited. The $\mathrm{O}_{2}$ pulse does not affect the $\mathrm{N}_{2} \mathrm{O}$ decomposition pathway, as the adsorbed $\mathrm{O}$ from the $\mathrm{O}_{2}$ pulse does not interact with any of the species in the $\mathrm{Cu}^{+} \rightarrow \mathrm{Cu}^{+}-\mathrm{N}_{2} \mathrm{O}, \mathrm{Cu}^{+}-\mathrm{ON}_{2} \rightarrow$ $\mathrm{Cu}^{2+} \mathrm{O}^{-} \rightarrow \mathrm{Cu}^{+}$redox path. This redox path proceeds in such rapid manner in the $\mathrm{N}_{2} \mathrm{O}$ decomposition pathway that the adsorbed $\mathrm{O}$ species cannot alter the dynamics of this route. $\mathrm{O}_{2}$ also does not alter the route for $\mathrm{Cu}^{2+}\left(\mathrm{NO}_{3}{ }^{\circ}\right)$ formation, as the adsorbed $\mathrm{O}$ species does not promote the formation of the precursor $\left(\mathrm{Cu}^{+}-\mathrm{N}_{2} \mathrm{O} / \mathrm{Cu}^{+}-\mathrm{ON}_{2}\right)$ for the nitrato- species formation. CO pulse affects the pathway similar to the $\mathrm{H}_{2}$ pulse with regards to the formation of additional $\mathrm{Cu}^{+}$sites that would promote $\mathrm{N}_{2}$ formation. In addition, the $\mathrm{CO}$ pulse leads to the reaction of 
adsorbed $\mathrm{CO}$ with the nitrato- species which produces not only more $\mathrm{Cu}^{+}$sites but also promotes $\mathrm{O}_{2}$ formation: $\mathrm{Cu}^{2+}\left(\mathrm{NO}_{3}{ }^{-}\right)+\mathrm{CO} \rightarrow \mathrm{Cu}^{+}+\mathrm{NO}+\mathrm{O}_{2}$.

\section{NO Decomposition}

$\mathrm{NO}$ decomposition to $\mathrm{N}_{2}, \mathrm{~N}_{2} \mathrm{O}$, and $\mathrm{O}_{2}$ proceeds via $\mathrm{Cu}^{+}(\mathrm{NO}), \mathrm{Cu}^{2+}(\mathrm{NO})$, bridging and chelating $\mathrm{Cu}^{2+}\left(\mathrm{NO}_{3}{ }^{-}\right)$, and $\mathrm{NO}^{+}$at $673 \mathrm{~K}$ as shown in Figs. 3, 4, 7, 8, 11, and 12. The sequence of formation of these adsorbate species, as reported in earlier studies $(22,23)$, is $\mathrm{Cu}^{+}(\mathrm{NO})>$ $\mathrm{Cu}^{2+}(\mathrm{NO}), \mathrm{Cu}^{2+} \mathrm{O}^{-}(\mathrm{NO})>\mathrm{NO}^{+}>\mathrm{Cu}^{2+}\left(\mathrm{NO}_{3}{ }^{-}\right)$. The $\mathrm{O}_{2}$ pulse into NO results showed that upon $\mathrm{O}_{2}$ addition a decrease in $\mathrm{Cu}^{+}(\mathrm{NO})$ led to a corresponding increase in the bridging and chelating $\mathrm{Cu}^{2+}\left(\mathrm{NO}_{3}{ }^{-}\right)$while the $\mathrm{Cu}^{2+}(\mathrm{NO})$ did not show any changes (Figs. 7 and 8). If the formation of bridging and chelating $\mathrm{Cu}^{2+}\left(\mathrm{NO}_{3}{ }^{-}\right)$goes through $\mathrm{Cu}^{2+}(\mathrm{NO})$ any change in $\mathrm{Cu}^{+}(\mathrm{NO})$ should be followed by changes in $\mathrm{Cu}^{2+}(\mathrm{NO})$, which is not the case here. Hence, the route for the formation of the $\mathrm{Cu}^{2+}\left(\mathrm{NO}_{3}{ }^{-}\right)$species may proceed via $\mathrm{Cu}^{+}(\mathrm{NO})$ but not through $\mathrm{Cu}^{2+}(\mathrm{NO})$. Step and pulse transient switching of NO at $303 \mathrm{~K}$ and $673 \mathrm{~K}$ has however shown in our earlier studies that $\mathrm{Cu}^{2+}(\mathrm{NO})$ is involved in the pathway for bridging and chelating $\mathrm{Cu}^{2+}\left(\mathrm{NO}_{3}{ }^{-}\right)$formation $(22,23)$. These results combined with the $\mathrm{O}_{2}$ pulse results in the present study suggest the existence of two routes for the formation of bridging and chelating $\mathrm{Cu}^{2+}\left(\mathrm{NO}_{3}{ }^{-}\right)$from $\mathrm{Cu}^{+}(\mathrm{NO})$ as shown in schemes $\mathrm{B}$. However, it is clear that $\mathrm{Cu}^{+}(\mathrm{NO})$ can be oxidized to the bridging and chelating $\mathrm{Cu}^{2+}\left(\mathrm{NO}_{3}{ }^{-}\right)$directly as indicated.

Addition of known reductants, $\mathrm{H}_{2}$ and $\mathrm{CO}$, under NO decomposition conditions promoted the reduction of $\mathrm{Cu}^{2+}$ adsorbates $\left(\mathrm{Cu}^{2+}\left(\mathrm{NO}_{3}{ }^{-}\right)\right.$and $\left.\mathrm{Cu}^{2+}(\mathrm{NO})\right)$ and $\mathrm{Cu}^{2+}$ sites to produce additional $\mathrm{Cu}^{+}$sites and hence $\mathrm{Cu}^{+}$adsorbates $\left(\mathrm{Cu}^{+}(\mathrm{NO})\right)$ that are available for $\mathrm{NO}$ adsorption and dissociation (Figs. 3, 4, 11, and 12). Formation of these additional $\mathrm{Cu}^{+}$sites promoted the NO 
decomposition reaction to produce more $\mathrm{N}_{2}, \mathrm{O}_{2}$, and $\mathrm{N}_{2} \mathrm{O}$ confirming that under reducing conditions the NO decomposition activity is increased due to the presence of more $\mathrm{Cu}^{+}$sites. Enhancement of NO activity also confirms that the $\mathrm{Cu}^{+}$sites are the active centers for the NO decomposition reaction on $\mathrm{Cu}-\mathrm{ZSM}-5$. Whether these active $\mathrm{Cu}^{+}$sites are isolated or in dimer $\left(\mathrm{Cu}^{+} \ldots \mathrm{Cu}^{+}\right)$form remains to be investigated.

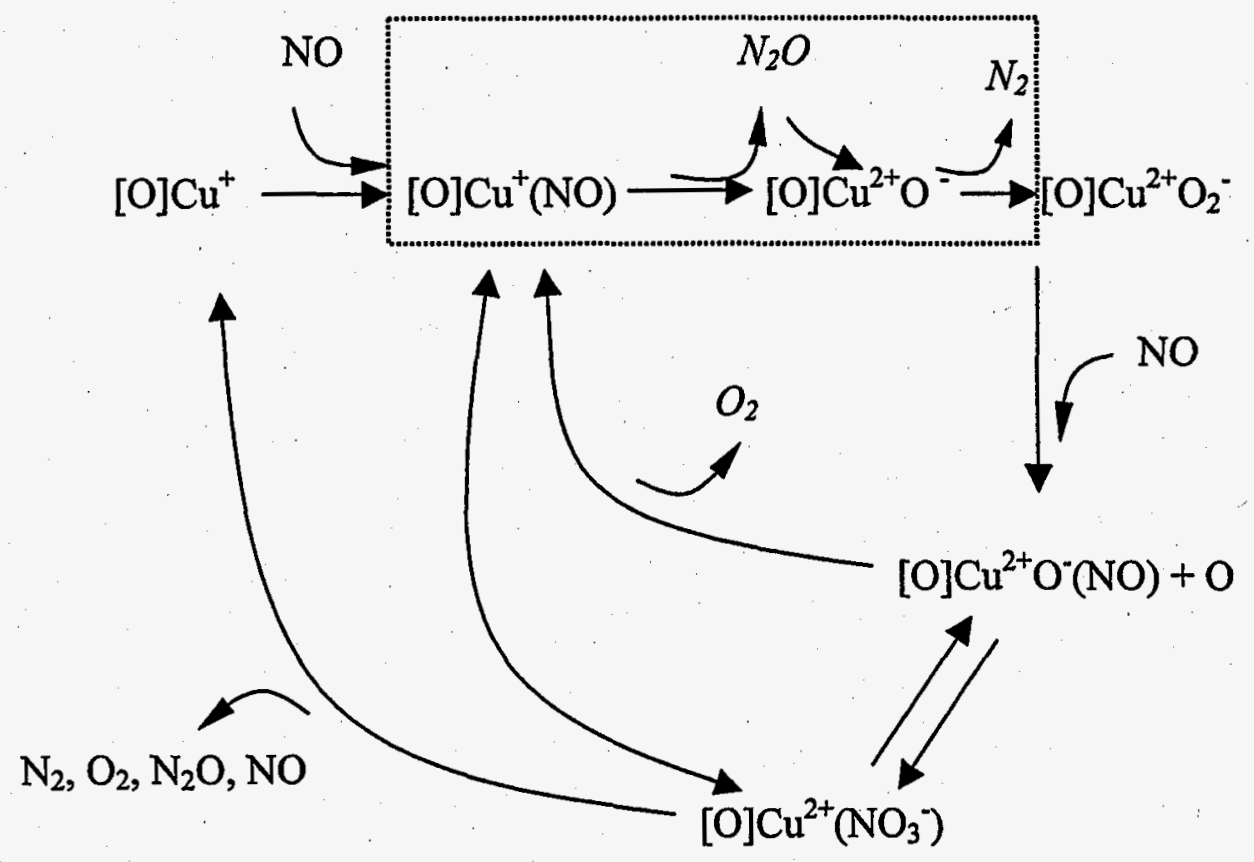

\section{Scheme B}

$\mathrm{NO}$ vs $\mathrm{N}_{2} \mathrm{O}$ Decomposition

$\mathrm{Cu}^{+}$is the active site on which both $\mathrm{NO}$ and $\mathrm{N}_{2} \mathrm{O}$ decomposition reactions are initiated on $\mathrm{Cu}-\mathrm{ZSM}-5$ as shown in schemes $1-3$. $\mathrm{NO}$ and $\mathrm{N}_{2} \mathrm{O}$ initially adsorb as $\mathrm{Cu}^{+}-\mathrm{NO}$ and $\mathrm{Cu}^{+}-\mathrm{N}_{2} \mathrm{O}$ and $\mathrm{Cu}^{+}-\mathrm{ON}_{2}$ which undergo dissociation and then interaction to produce the different adsorbate species $\left(\mathrm{Cu}^{2+} \mathrm{O}^{-}, \mathrm{Cu}^{2+} \mathrm{O}_{2}^{-}, \mathrm{Cu}^{2+}\left(\mathrm{NO}_{3}{ }^{-}\right)\right)$and ultimately the products $\left(\mathrm{N}_{2}\right.$ and $\left.\mathrm{O}_{2}\right)$. The adsorbed $\mathrm{O}$ produced during NO decomposition is different from that produced during $\mathrm{N}_{2} \mathrm{O}$ decomposition in 
the following ways: (i) adsorbed $\mathrm{O}$ from $\mathrm{N}_{2} \mathrm{O}$ decomposition reacts with the adsorbed $\mathrm{H}$ species during $\mathrm{H}_{2}$ pulse to produce $\mathrm{Cu}^{2+} \mathrm{OH}$ and in the process not promoting $\mathrm{O}_{2}$ formation while the adsorbed $\mathrm{O}$ from $\mathrm{NO}$ decomposition does not interact with adsorbed $\mathrm{H}$ and hence promotes $\mathrm{O}_{2}$ formation, and (ii) $\mathrm{CO}$ pulse into $\mathrm{NO}$ promoted formation of additional $\mathrm{Cu}^{+}$sites and also $\mathrm{O}_{2}$ formation as indicated by the increase in $\mathrm{O}_{2}$ concentration in Fig. 8 while the $\mathrm{CO}$ pulse into $\mathrm{N}_{2} \mathrm{O}$ also promoted additional $\mathrm{Cu}^{+}$formation but promoted the formation of two types of $\mathrm{O}_{2}$ as indicated by two peaks of $\mathrm{O}_{2}$ concentration in Fig. 10. The present study establishes the existence of different types of adsorbed $\mathrm{O}$ during $\mathrm{NO}$ and $\mathrm{N}_{2} \mathrm{O}$ decomposition but does not indicate the coordination and dynamics of these species. 


\section{References}

1. Hightower, J. W., Van Leirsburg, D. A., The Catalytic Chemistry of Nitrogen Oxides, Klimisch, R. L. and Larson, J. G., Eds., Plenum Press, New York, 1975.

2. Iwamoto, M., in "Future Opportunities in Catalytic and Separation Technology", (Misono, M., Moro-oka, Y., and Kimura, S., Eds., Elsevier, Amsterdam-Oxford-New York-Tokyo, 1990.

3. Heck, R. M., Farrauto, R. J., Catalytic Air Pollution Control, Commercial Technology, Van Nostrand Reinhold, 1995.

4. Shelef, M., Chem. Rev. 95, 209 (1995).

5. Swamy, C. S., Christopher, J., Catal. Rev.-Sci. Eng. 34, 409 (1992).

6. Li, Y., Armor, J. N., Appl. Catal. B 3, 55 (1993).

7. Chang, Y.-F., McCarty, J. G., Wachsman, E. D., Wong, V. L., Appl. Catal. B 4, 283 (1994).

8. Kapteijn, F., Rodriguez-Mirasol, J., Moulijn, J. A., Appl. Catal. B 9, 25 (1996).

9. Iwamoto, M., Yoko, S., Sakai, K., and Kagawa, S., J. Chem. Soc. Faraday Trans. 1, 77, $1629(1981)$.

10. Iwamoto, M., Furukawa, H., and Kagawa, S., in "New Developments in Zeolite Science and Technology" (Murukama, Y., Ichijima, A., and Ward, J. W., Eds.), p 943. Elsevier, Amsterdam, 1986.

11. Li, Y. and Hall, W. K., J. Phys. Chem. 94, 6145 (1990).

12. Aylor, A. W., Larsen, S. C., Reimer, J. A. and Bell, A. T., J. Catal. 157, 592 (1995).

13. Iwamoto, M., Yahiro, H., Mizuno, N., Zhang, W. -X., Mine, Y., Furukawa, H. and Kagawa, S., J. Phys. Chem. 96, 9360 (1992).

14. Giamello, E., Murphy, D., Magnacca, G., Morterra, C., Shioya, Y., Nomura, T., and Anpo, M., J. Catal. 136, 510 (1992).

15. Valyon, J. and Hall, W. K., in "New Frontiers in Catalysis", Proceedings of the $10^{\text {th }}$ International Congress on Catalysis, 1992 (Guczi, L., Solymosi, F., Tetenyi, P., Ed.), p 1341, Akademiai Kiado: Budapest, Hungary, 1993.

16. Spoto, G., Zecchina, A., Bordiga, S., Ricchiardi, G., Marta, G. Leofanti, G., and Petrini, G., Appl. Catal B 3, 151 (1994). 
17. Hoost, T. B., Laframboise, K. A., and Otto, K., Catal. Lett. 33, 105 (1995).

18. Cheung, T., Bhargava, S. K., Hobday, M., and Foger, K., J. Catal 158, 301 (1996).

19. Iwamoto, M., Yahiro, H., Tanda, K., Mizuno, N., Mine, Y., and Kagawa, S., J. Phys. Chem. 95, 3727 (1991).

20. Adelman, B. J., Beutel, T., Lei, G. -D., and Sachtler, W. M. H., J. Catal. 158, 327 (1996).

21. Hadjiivanov, K., Saussey, J., Freysz, J. L., and Lavalley, J. C., Catal. Lett. 52, 103 (1998).

22. Konduru, M. V., Chuang, S. S. C., J. Phys. Chem. B 103, 5802 (1999).

23. Konduru, M. V., Chuang, S. S. C., J. Catal. 187, 436 (1999).

24. Chuang, S. S. C., Brundage, M. A., Balakos, M., and Srinivas, G., Appl. Spectrosc. 49 (8), 1151 (1995).

25. Hussain, G., Rahman, M. M., and Sheppard, N., Spectrochimica Acta 47A, 1525 (1991).

26. Miller, T. M. and Grassian, V. H., Colloids and Surfaces 105, 113 (1995).

27. Miller, T. M. and Grassian, V. H, J. Am. Chem. Soc. 117, 10969 (1995).

28. Kustov, L. M., Smekalina, E. V., Uvarova, E. B., and Kazansky, V. B., in "Zeolites: A Refined Tool for Designing Catalytic Sites", Bonneviot, L. and Kaliaguine, S. (Eds.), Elsevier Science, 1995.

29. Miyata, H., Konishi, S., Ohno, T., and Hatayama, F., J. Chem. Soc. Faraday Trans. 91, 1557 (1995).

30. Lin, J., Chen, H. Y., Chen, L., Tan, K. L., and Zeng, H. C., Appl. Surf. Sci. 103, 307 (1996).

31. Borello, E., Cerruti, L., Ghiotti, G., and Guglielminotti, E., Inorg. Chim. Acta 6, 45 (1972).

32. Forster, H., Remmert, M., J. Mol. Structure 174, 357 (1988).

33. Nakamoto, K. Infrared and Raman Spectra of Inorganic and Coordination Compounds, $3^{\text {rd }}$ ed.; John Wiley \& Sons: New York, 1978.

34. Sárkány, J., Appl. Catal. A 188, 369 (1999).

35. Peuker, Ch., J. Mol. Structure 349, 317 (1999). 


\section{$\underline{\text { List of Figures }}$}

Figure 1 IR spectra and MS profiles collected during the temperature-programmed reaction (TPR) over Cu-ZSM-5-523 in a 5\% NO in He stream from 373 to $753 \mathrm{~K}$.

Figure 2 IR spectra and MS profiles collected during the temperature-programmed reaction (TPR) over Cu-ZSM-5-523 in a $5 \% \mathrm{~N}_{2} \mathrm{O}$ in He stream from 373 to $753 \mathrm{~K}$..

Figure 3 IR spectra taken during the first $1 \mathrm{~cm}^{3}$ of $\mathrm{H}_{2}$ pulse into $5 \% \mathrm{NO}$ stream over $\mathrm{Cu}$ ZSM-5-523 at $673 \mathrm{~K}$.

Figure $4 \quad$ MS intensity profiles of reactor effluent and IR intensity profiles of adsorbate species collected during the first $1 \mathrm{~cm}^{3}$ of $\mathrm{H}_{2}$ pulse into $5 \%$ NO stream over $\mathrm{Cu}$ ZSM-5-523 at $673 \mathrm{~K}$.

Figure 5 IR spectra taken during the first $1 \mathrm{~cm}^{3}$ of $\mathrm{H}_{2}$ pulse into $5 \% \mathrm{~N}_{2} \mathrm{O}$ stream over $\mathrm{Cu}$ ZSM-5-523 at $673 \mathrm{~K}$.

Figure $6 \quad$ MS intensity profiles of reactor effluent and IR intensity profiles of adsorbate species collected during the first $1 \mathrm{~cm}^{3}$ of $\mathrm{H}_{2}$ pulse into $5 \% \mathrm{~N}_{2} \mathrm{O}$ stream over $\mathrm{Cu}$ ZSM-5-523 at $673 \mathrm{~K}$.

Figure 7 IR spectra taken during the first $1 \mathrm{~cm}^{3}$ of $\mathrm{O}_{2}$ pulse into $5 \%$ NO stream over $\mathrm{Cu}-$ ZSM-5-523 at $673 \mathrm{~K}$.

Figure $8 \quad$ MS intensity profiles of reactor effluent and IR intensity profiles of adsorbate species collected during the first $1 \mathrm{~cm}^{3}$ of $\mathrm{O}_{2}$ pulse into $5 \%$ NO stream over CuZSM-5-523 at $673 \mathrm{~K}$.

Figure 9 IR spectra taken during the first $1 \mathrm{~cm}^{3}$ of $\mathrm{CO}$ pulse into $5 \%$ NO stream over $\mathrm{Cu}$ ZSM-5-523 at $673 \mathrm{~K}$

Figure $10 \quad$ MS intensity profiles of reactor effluent and IR intensity profiles of adsorbate species collected during the first $1 \mathrm{~cm}^{3}$ of $\mathrm{CO}$ pulse into $5 \%$ NO stream over $\mathrm{Cu}-$ ZSM-5-523.

Figure 11 IR spectra taken during the first $1 \mathrm{~cm}^{3}$ of $\mathrm{CO}$ pulse into $5 \% \mathrm{~N}_{2} \mathrm{O}$ stream over $\mathrm{Cu}$ ZSM-5-523 at $673 \mathrm{~K}$.

Figure 12 MS intensity profiles of reactor effluent and IR intensity profiles of adsorbate species collected during the first $1 \mathrm{~cm}^{3}$ of $\mathrm{CO}$ pulse into $5 \% \mathrm{~N}_{2} \mathrm{O}$ stream over $\mathrm{Cu}$ ZSM-5-523. 
Figure 13 IR spectra taken during the first $1 \mathrm{~cm}^{3}$ of $\mathrm{N}_{2} \mathrm{O}$ pulse into $5 \% \mathrm{NO}$ over $\mathrm{Cu}-\mathrm{ZSM}-5-$ 523 at $673 \mathrm{~K}$.

Figure 14 MS intensity profiles of reactor effluent and IR intensity profiles of adsorbate species collected during the first $1 \mathrm{~cm}^{3}$ of $\mathrm{N}_{2} \mathrm{O}$ pulse into $5 \%$ NO stream over $\mathrm{Cu}$ ZSM-5-523. 

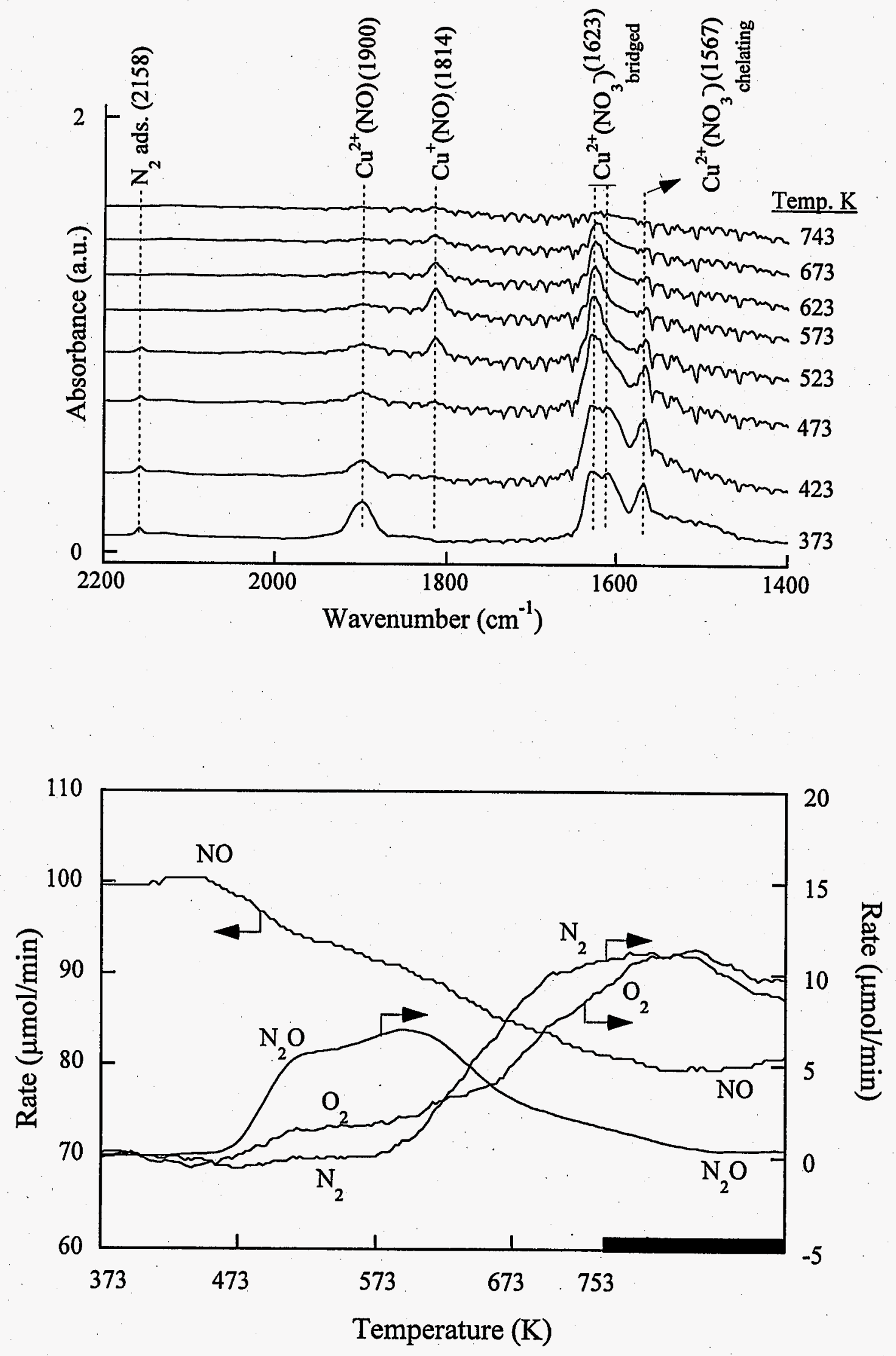

Figure 1 

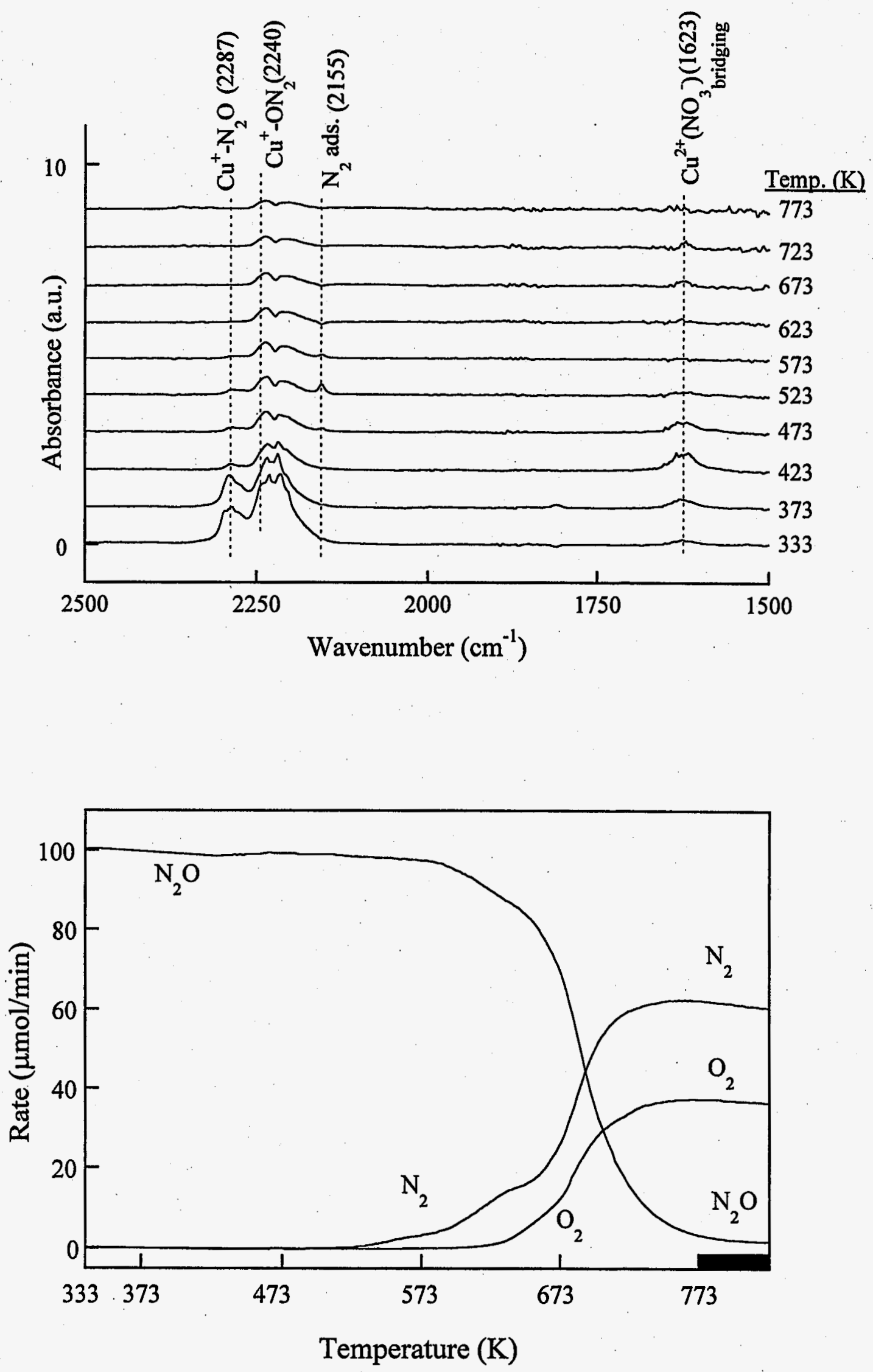

Figure 2 


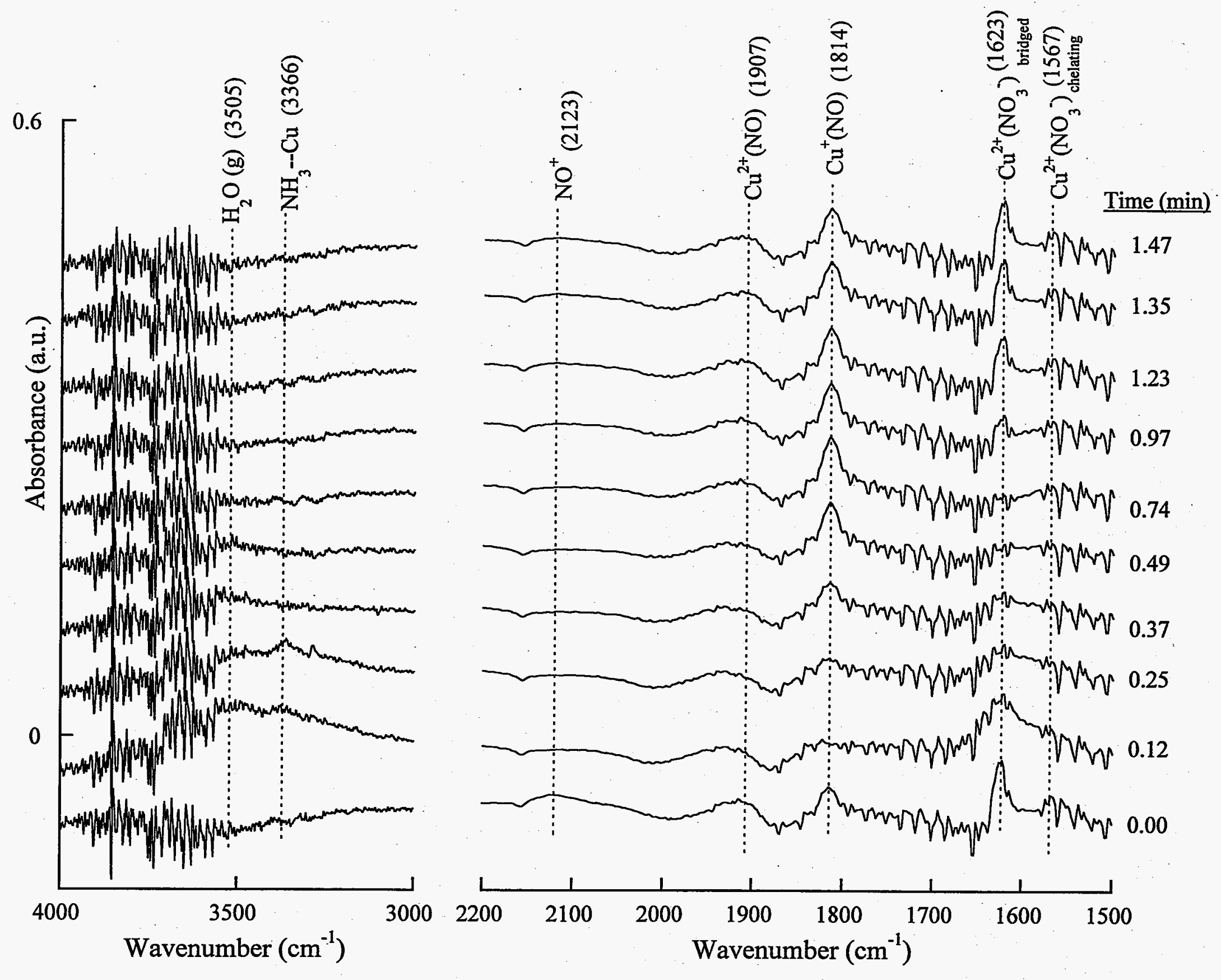




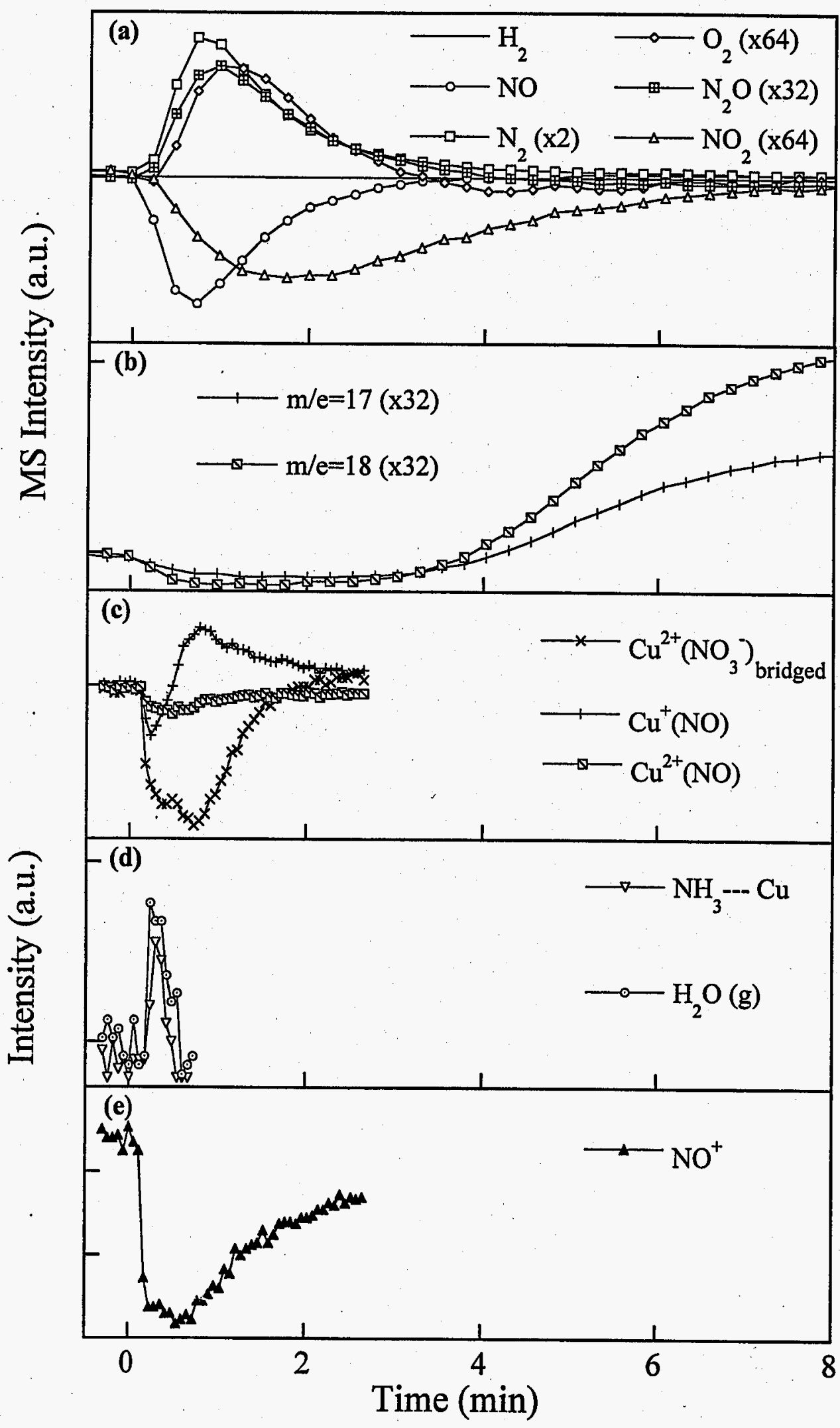

Figure 4 


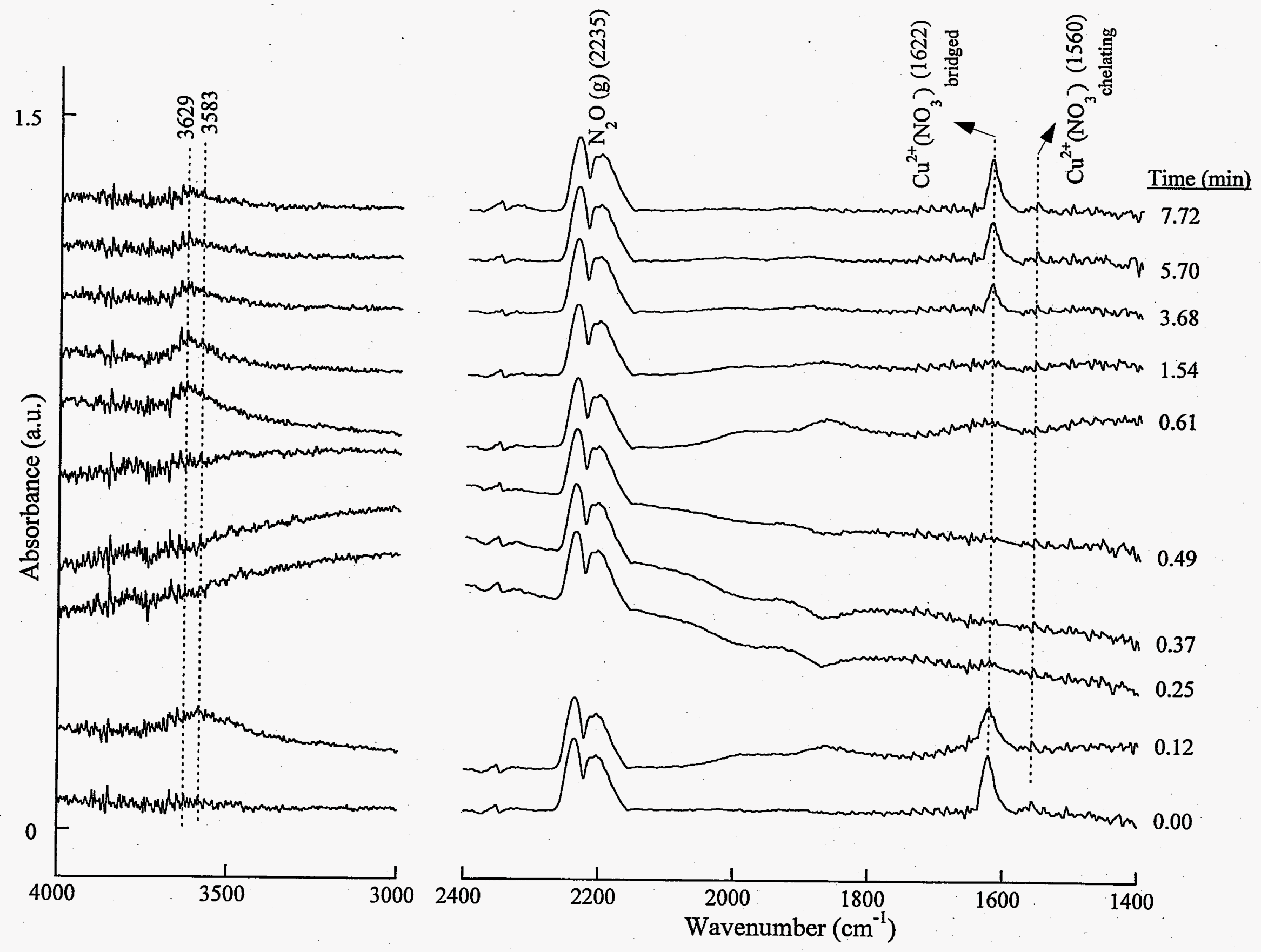

Figure 5 


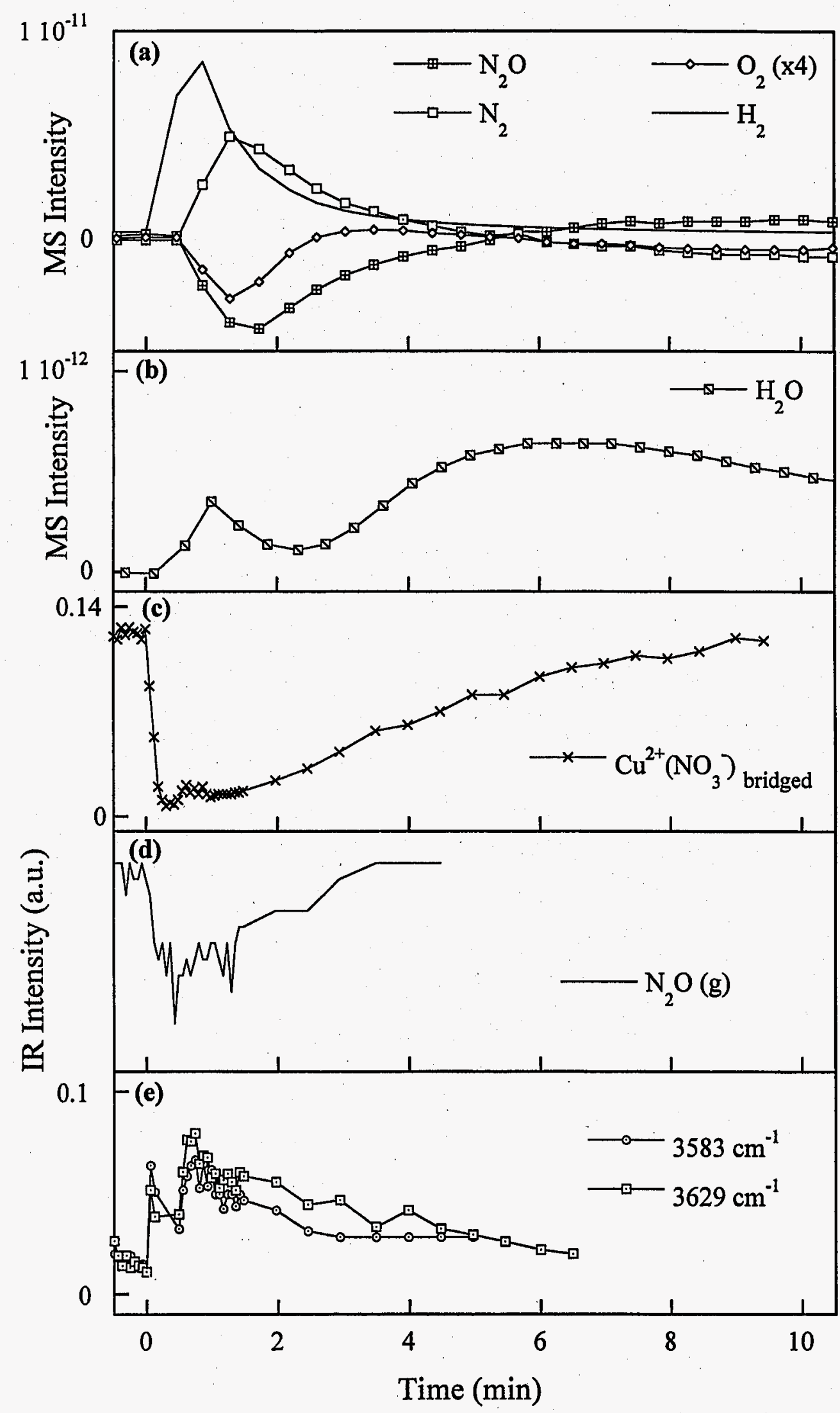

Figure 6 


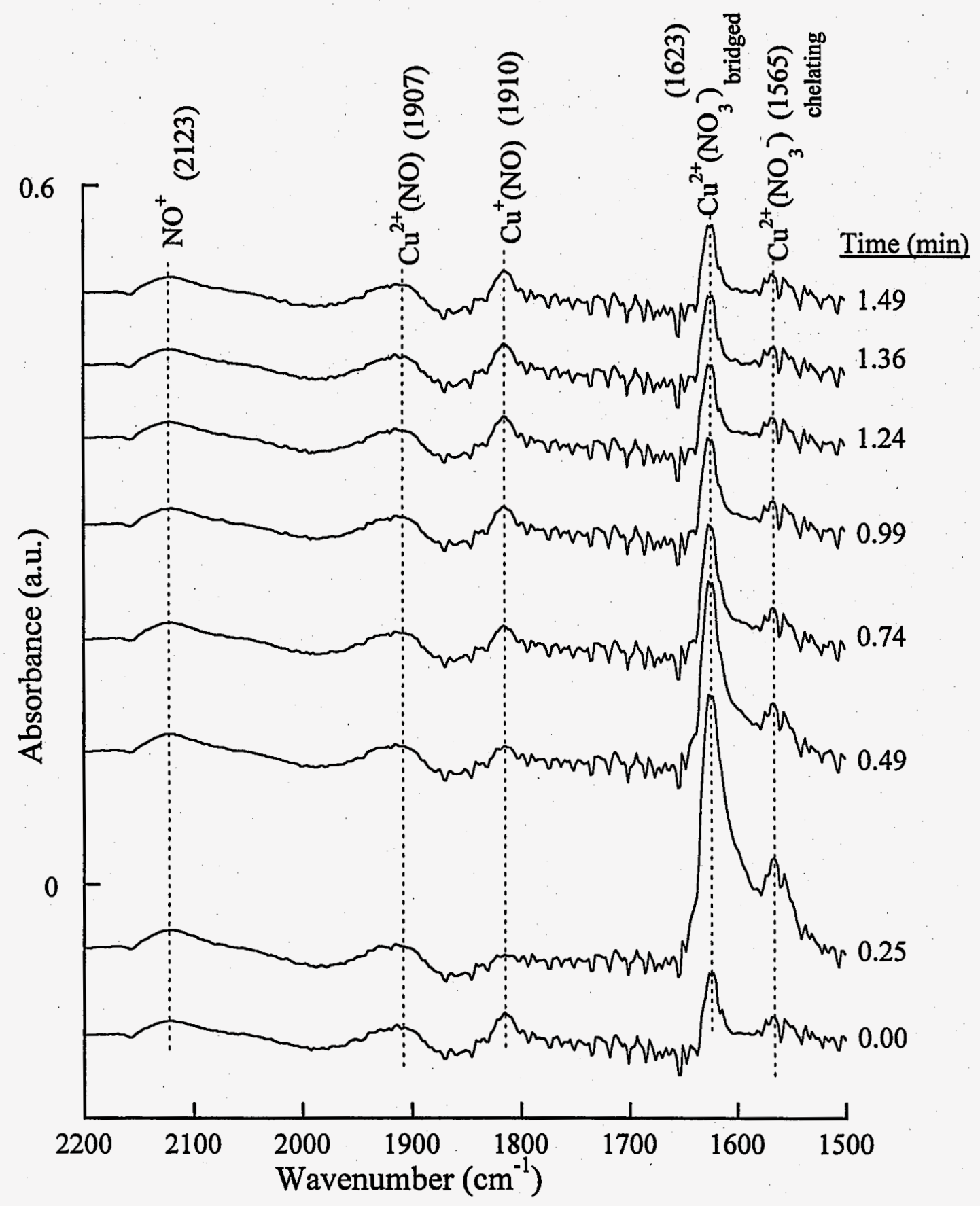




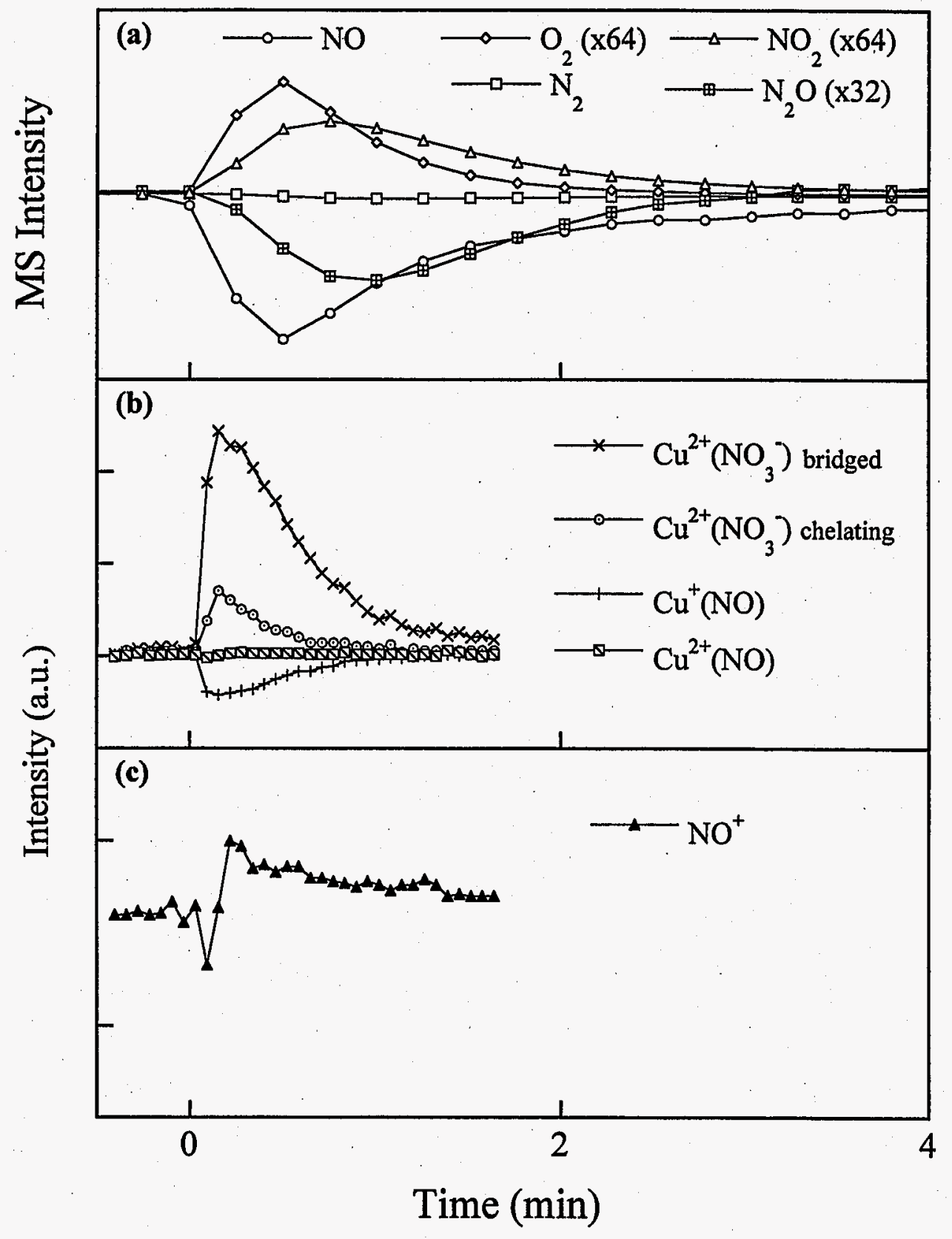

Figure 8 


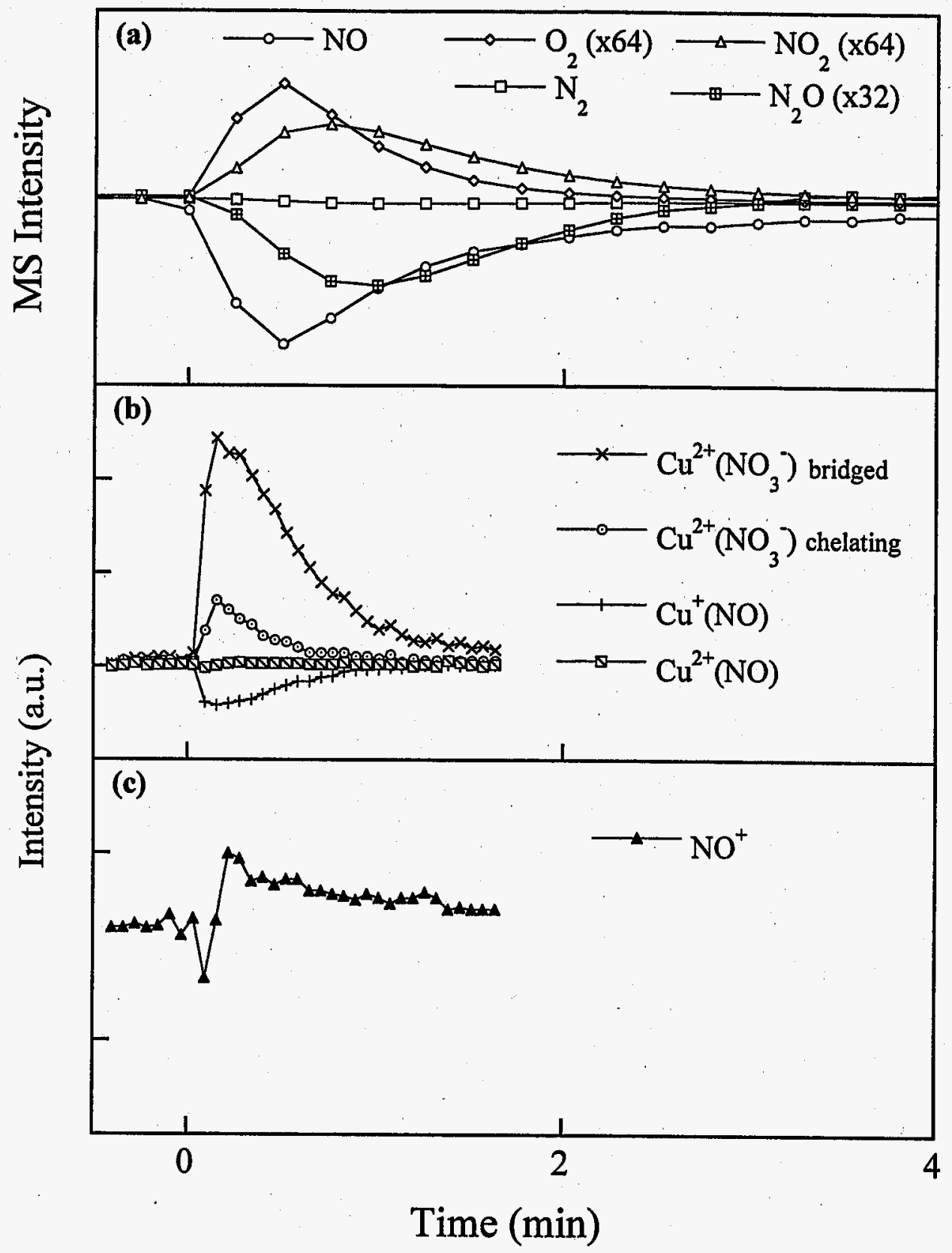

Figure 8 


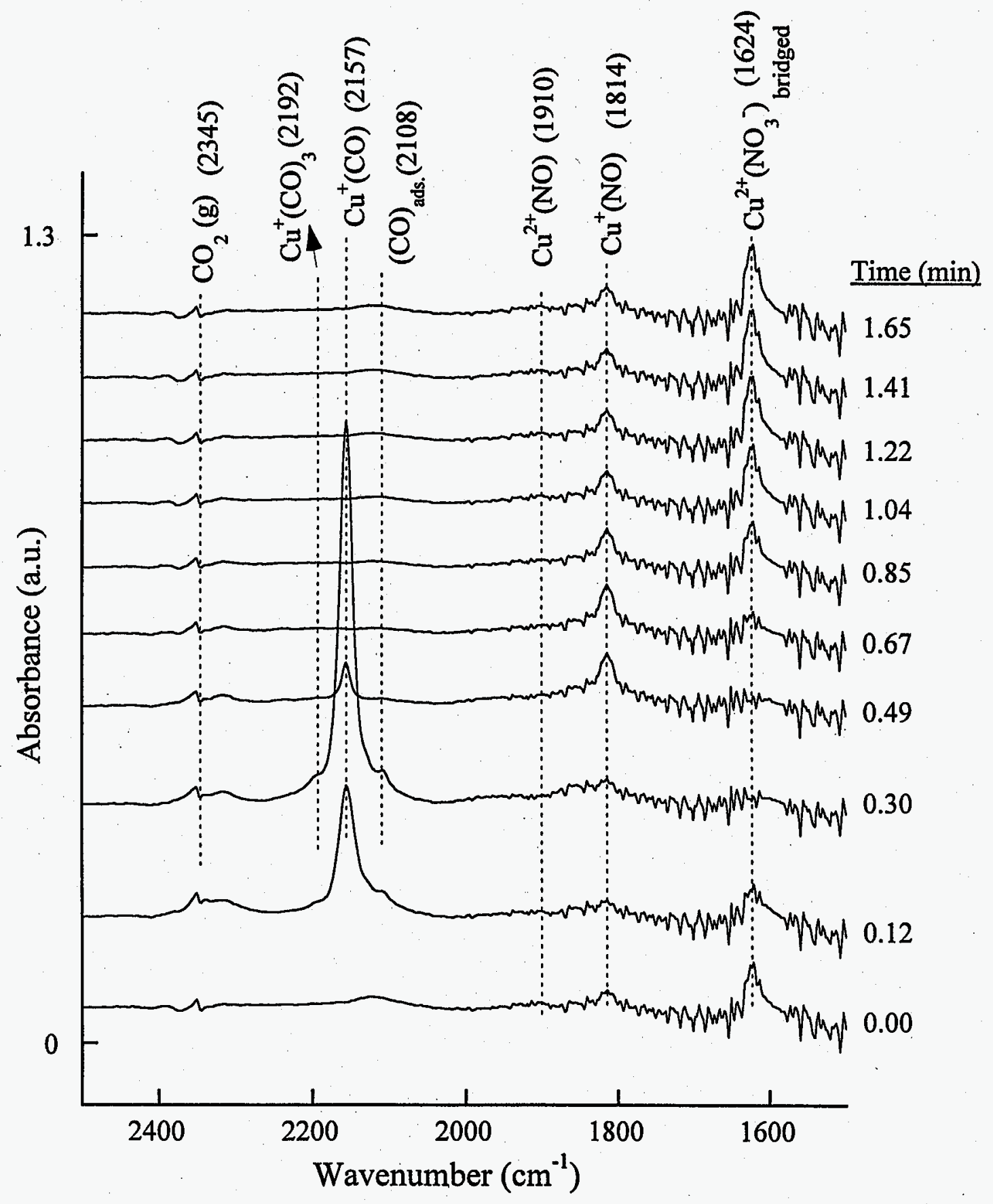

Figure 9 


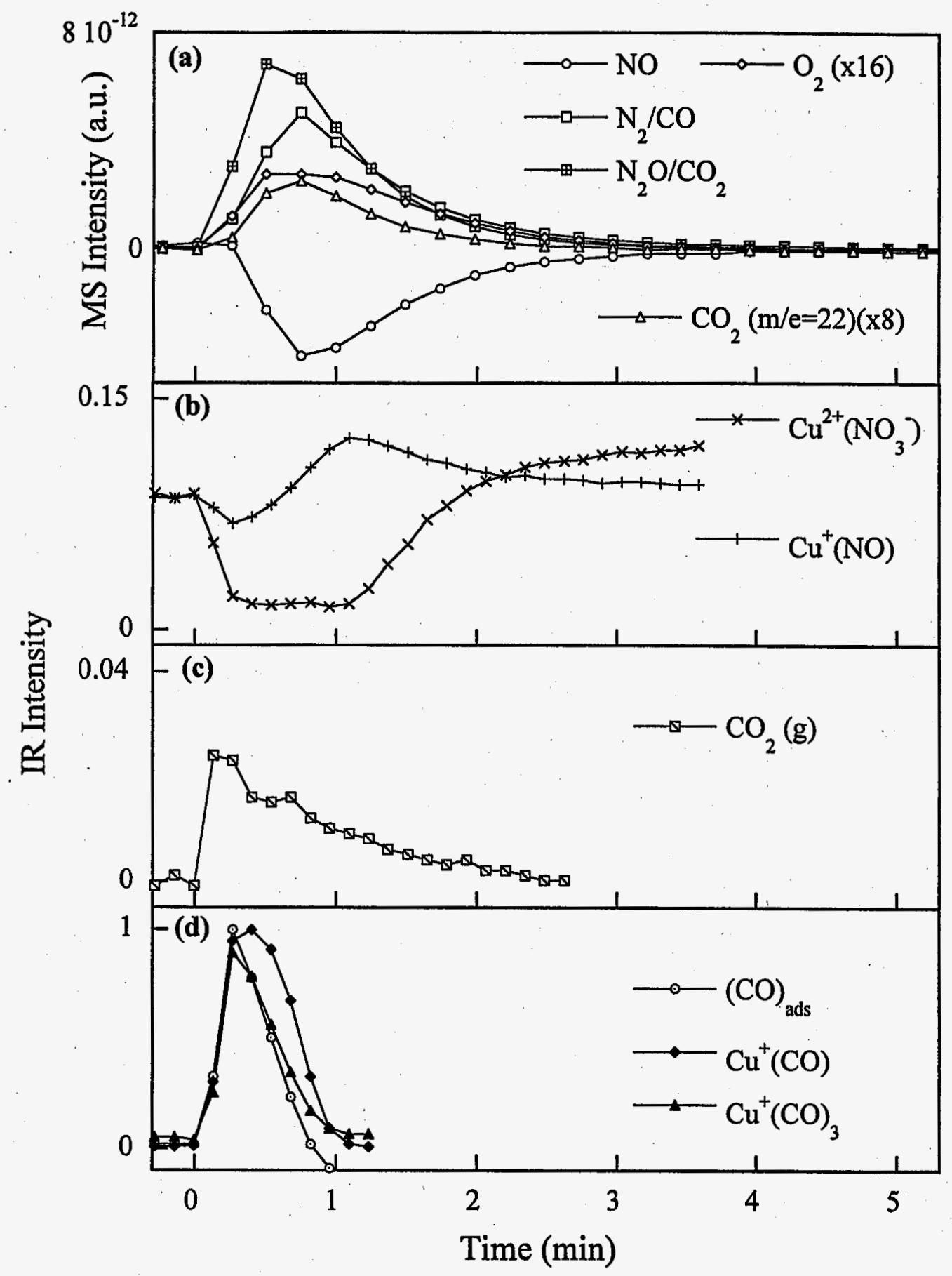

Figure 10 


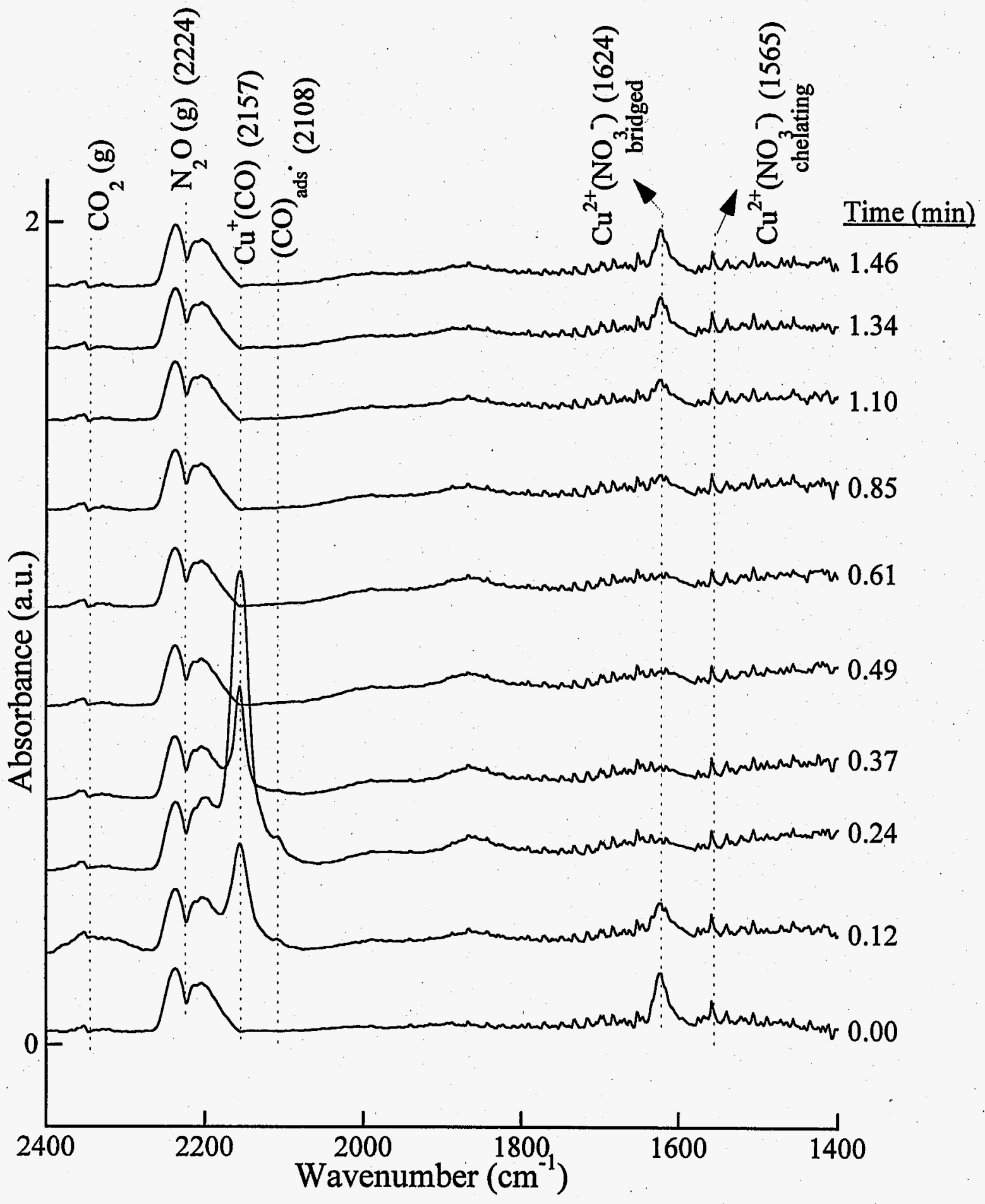




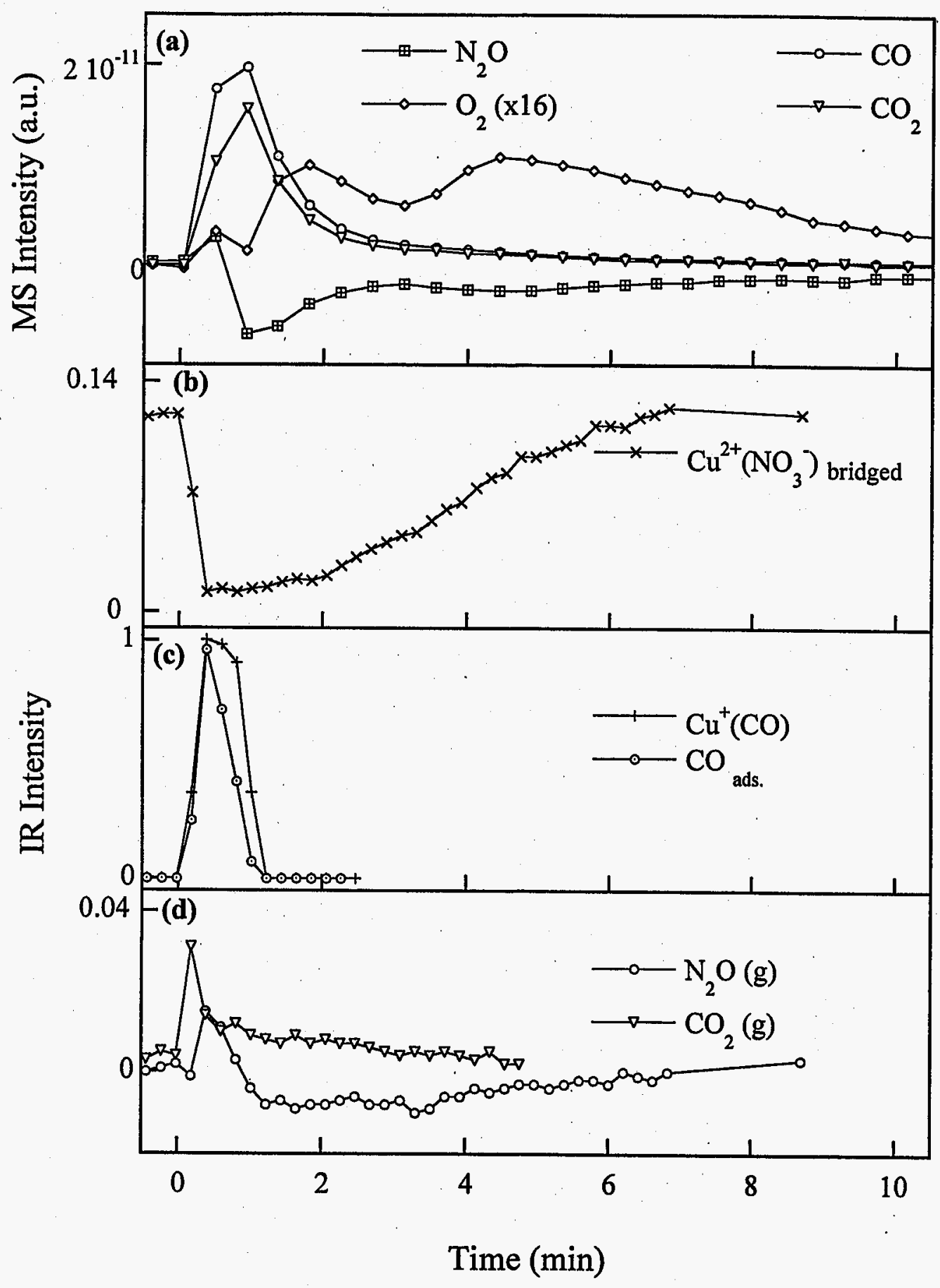

Figure 12 


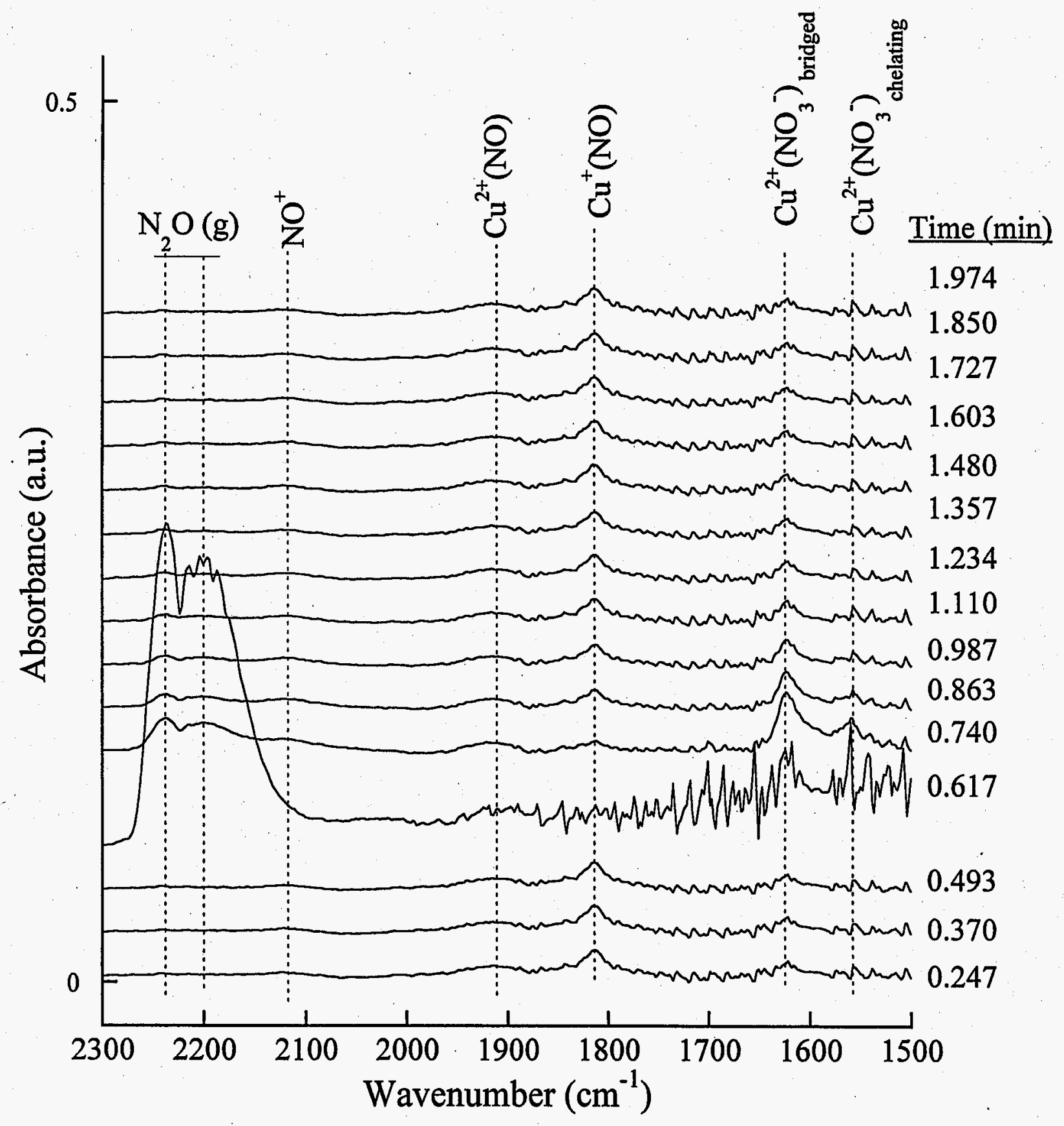

Figure 13 


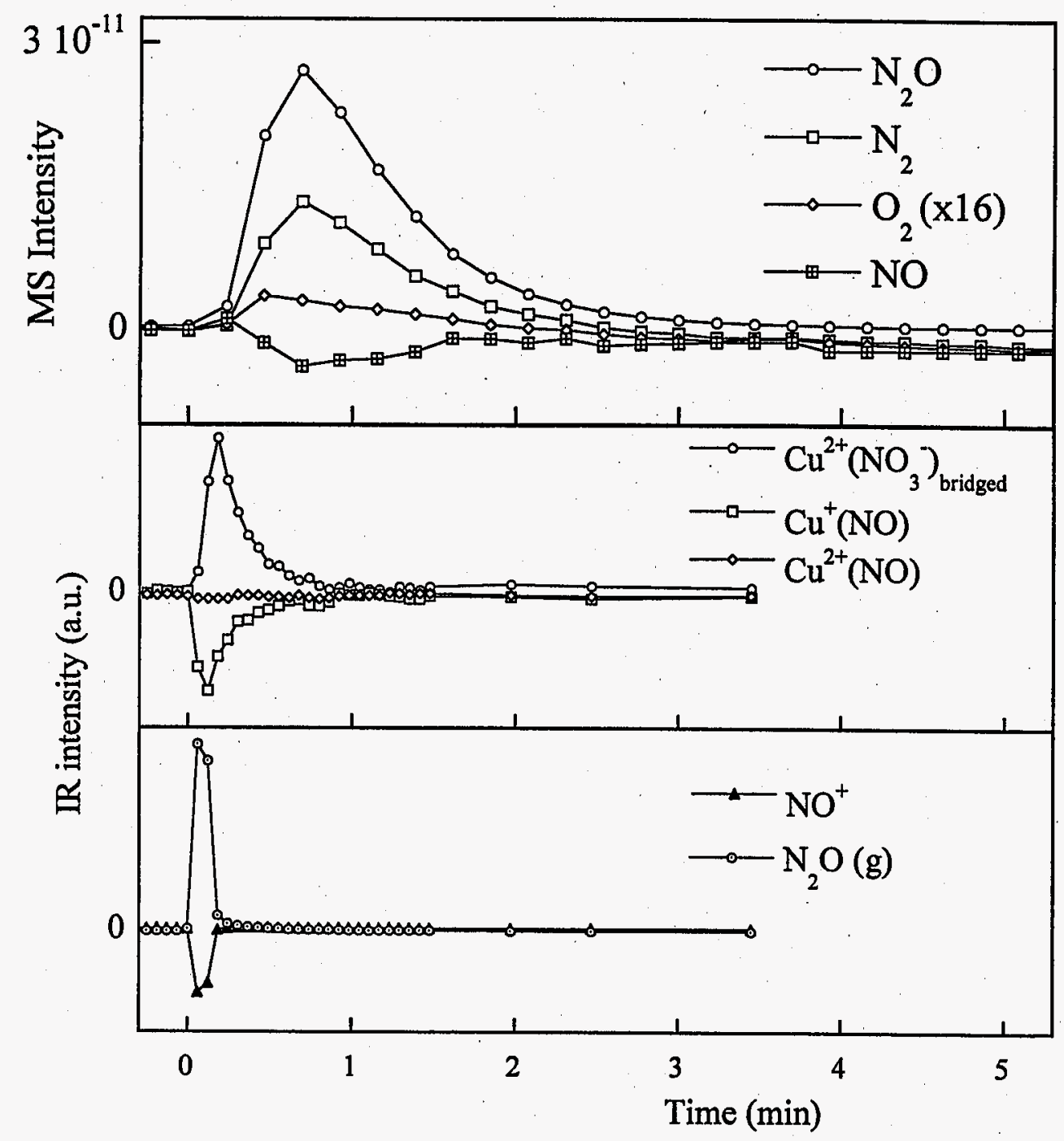

Figure 14 


\title{
Determination of the Feasibility of Using Silane to Improve the Sintering and Dealumination Resistance of Cu-ZSM-5
}

\begin{abstract}
Site-poisoning and -promotion technique was employed to investigate the role of
\end{abstract} adsorbates and formulate a reaction pathway for the NO decomposition reaction over Cu-ZSM-5. Transient infrared and mass spectrometer studies of pulse NO reaction on under- and overexchanged $\mathrm{Cu}-\mathrm{ZSM}-5$ reveal $\mathrm{Cu}^{2+}(\mathrm{NO}), \mathrm{Cu}^{+}(\mathrm{NO})$, bridging $\mathrm{Cu}^{2+}\left(\mathrm{NO}_{3}{ }^{-}\right)$, and $\mathrm{NO}^{+}$as the major adsorbates and $\mathrm{N}_{2}, \mathrm{~N}_{2} \mathrm{O}, \mathrm{O}_{2}$, and $\mathrm{NO}_{2}$ as the products. $\mathrm{SiH}_{4}$ and $\mathrm{H}_{2} \mathrm{O}$ moderately inhibited $\mathrm{Cu}^{+}(\mathrm{NO})$ and $\mathrm{N}_{2}$ formation, but severely inhibited $\mathrm{Cu}^{2+}\left(\mathrm{NO}_{3}{ }^{-}\right)$and $\mathrm{O}_{2}$ formation. Addition of $\mathrm{CO}$ as a reducing agent led to promotion of $\mathrm{Cu}^{2+}$ reduction to $\mathrm{Cu}^{+}$, depletion of $\mathrm{Cu}^{2+}\left(\mathrm{NO}_{3}\right)^{2}$, increase in $\mathrm{NO}$ conversion and $\mathrm{O}_{2}$ formation, as well as formation of $\mathrm{CO}_{2}$. These results revealed that $\mathrm{N}_{2}$ and $\mathrm{O}_{2}$ formation proceeds through separate rate-limiting steps; $\mathrm{O}_{2}$ formation occurs via both auto-reduction of $\mathrm{Cu}^{2+}$ to $\mathrm{Cu}^{+}$and decomposition of $\mathrm{Cu}^{2+}\left(\mathrm{NO}_{3}{ }^{-}\right)$.

The results from pulse reaction studies on deactivated $\mathrm{Cu}-\mathrm{ZSM}-5$ reveal that $\mathrm{O}_{2}$ formation is more sensitive to poisoning than $\mathrm{NO}$ dissociation and $\mathrm{N}_{2}$ formation. Although silanation may improve the hydrothermal stability of the catalyst, silanation severely inhibited $\mathrm{O}_{2}$ and $\mathrm{Cu}^{2+}\left(\mathrm{NO}_{3}{ }^{-}\right)$formation through inhibition of adsorbed $\mathrm{O}$ migration.

Keywords: Site-poisoning; site-promotion; in situ IR; direct NO decomposition; Cu-ZSM-5; over-exchanged; under-exchanged; active adsorbates; spectator adsorbates; reaction mechanism; deactivation pathway. 


\section{INTRODUCTION}

In situ infrared (IR) is one of the few techniques that allows observation of adsorbates, including the active and spectator species, under reaction conditions $(1,2)$. To distinguish the active adsorbates from spectator adsorbates, transient IR techniques with variation of reactant partial pressure and isotope composition have been used (3-9). Due to the rapid exchange between gaseous reactants and adsorbates, information obtained solely from transient IR techniques does not allow unambiguous identification of active and spectator adsorbates.

The present study reports the use of transient IR technique coupled with site-poisoning and CO site-promotion to distinguish between active and spectator adsorbates from the IRobservable adsorbates during NO decomposition on under and over-exchanged Cu-ZSM-5. NO decomposition over Cu-ZSM-5 was selected as the model reaction as (i) Cu-ZSM-5 exhibits high NO decomposition activity (10-19) and (ii) the structure of adsorbates on the Cu-ZSM-5 catalyst has been well established, but their reactivity not yet completely determined. Mechanistic information on the adsorbates role in the reaction allows verification of various proposed NO decomposition mechanisms, unravels the limitation of Cu-ZSM-5 catalysts for NO decomposition, and guides catalyst development.

NO adsorbs as $\mathrm{Cu}^{+}$(NO) $\left(1814 \mathrm{~cm}^{-1}\right), \mathrm{Cu}^{2+}$ (NO) $\left(1910 \mathrm{~cm}^{-1}\right), \mathrm{Cu}^{2+} \mathrm{O}$ (NO) $\left(1895 \mathrm{~cm}^{-1}\right)$, $\mathrm{Cu}^{2+}(\mathrm{NO})_{2}\left(1733\right.$ and $\left.1835 \mathrm{~cm}^{-1}\right)$, adsorbed $\mathrm{NO}^{+}\left(2124 \mathrm{~cm}^{-1}\right)$, and $\mathrm{NO}_{\mathrm{x}}(\mathrm{x}=2$ or 3$)$ species $(1624$, $1601,1575,1315 \mathrm{~cm}^{-1}$ ) over Cu-ZSM-5 at temperatures ranging from 77 to $298 \mathrm{~K}$ and pressures from 0.07 to 39.9 Torr of NO (13-21). NO adsorption at higher temperatures $(>373 \mathrm{~K})$ produced low-intensity IR-observable adsorbates. Exposure of Cu-ZSM-5 to $6090 \mathrm{ppm}$ of NO at $573 \mathrm{~K}$ resulted in the appearance of weaker $\mathrm{Cu}^{+}(\mathrm{NO})$ and $\mathrm{Cu}^{2+}(\mathrm{NO})$ as well as stronger $\mathrm{NO}_{\mathrm{x}}(\mathrm{x}=2$ or 3$)$ (1500-1624 $\mathrm{cm}^{-1}$ region) species compared to those at room temperature (13). 
The band assignment for the $\mathrm{NO}_{\mathbf{x}}$ species has been uncertain despite numerous NO adsorption IR studies (13-15,18,20-22). The classical assignment of the nitrato- (M-NO 3 where $\mathrm{M}$ is a metal ion) and nitro- $\left(\mathrm{M}-\mathrm{NO}_{2}\right)$ complexes has been discussed in earlier studies (23-26). Bands above $1600 \mathrm{~cm}^{-1}$ were assigned to bridging nitrato- species; those below $1600 \mathrm{~cm}^{-1}$ to chelating bidentate nitrato species; and those below $1500 \mathrm{~cm}^{-1}$ to nitrito- and nitro- species $(24,25)$. The present study follows the classical band assignment: the band at $1624 \mathrm{~cm}^{-1}$ is assigned to the bridging nitrato- species; the bands at $1575 \mathrm{~cm}^{-1}$ to the chelating nitrato- species.

The role of the adsorbate species in the NO decomposition reaction needs to be identified in order to support the proposed reaction mechanisms. Since active sites bond the active adsorbates and catalyze their reactions, blocking active sites should inhibit the formation of active adsorbates and products. Water $\left(\mathrm{H}_{2} \mathrm{O}\right)$ and sulfur dioxide $\left(\mathrm{SO}_{2}\right)$ are known to poison the Cu-ZSM-5 catalyst for the NO decomposition reaction (27). It is expected that these species would block the active sites that chemisorb the active adsorbates. Although $\mathrm{H}_{2} \mathrm{O}$ and $\mathrm{SO}_{2}$ may also block the sites that adsorb spectator adsorbate species, the adsorbates observed on the poisoned catalyst must be adsorbed on the sites that are not directly blocked by the poisons. These types of adsorbates are classified as spectators in this study. Silane $\left(\mathrm{SiH}_{4}\right)$ treatment of zeolites, leading to the depletion of surface hydroxyl groups, rendered the zeolites thermal- and water-resistant (28). Pre-treating Cu-ZSM-5 with $\mathrm{SiH}_{4}$ would provide hydrothermal stability to the catalyst system. The investigation of adsorbate behavior on the $\mathrm{SiH}_{4}$ treated catalyst would allow determination of the extent of $\mathrm{SiH}_{4}$ modification on the NO decomposition activity. Surprisingly, $\mathrm{SiH}_{4}$ treatment, which was expected to impart hydrothermal stability to the $\mathrm{Cu}$ ZSM-5 catalyst, in fact poisoned the NO decomposition activity as shown in the present study. The poisoning of NO decomposition activity by silane, along with that by water and sulfur 
dioxide, was utilized for the identification of spectator and active adsorbates during NO decomposition over Cu-ZSM-5.

The main objective of this study is to shed new light into the dynamic behavior of adsorbates during the NO decomposition reaction over Cu-ZSM-5 sites poisoned by water, silane, and sulfur dioxide. Identification of the adsorbates role on the silane-, water- and sulfur dioxide-poisoned catalyst could reveal active and spectator adsorbates as well as explain the sitedeactivation and NO decomposition mechanisms.

\section{EXPERIMENTAL}

\section{Catalyst Preparation}

Copper-exchanged ZSM-5 catalysts with different $\mathrm{Cu}$ loading were used in the present study. The under-exchanged Cu-ZSM-5, labeled Cu-ZSM-5-83, with 83\% copper exchange was prepared by Johnson Matthey and supplied by the Catalyst bank of Sandia National Laboratories. The over-exchanged Cu-ZSM-5, labeled Cu-ZSM-5-127, with a $127 \%$ copper exchange was prepared by repeated ion exchange of $\mathrm{Cu}-\mathrm{ZSM}-5-83$ in a $0.07 \mathrm{M}$ copper acetate solution at a $\mathrm{pH}$ of 7. The amount of copper exchanged is defined as two times the ratio of copper and aluminum present in the catalyst sample (27). The catalyst samples were analyzed using inductively coupled plasma (ICP) emission spectroscopy (Galbraith Lab., Inc. Knoxville, TN 37921-1750) and their composition is listed in Table 1 . The Cu-ZSM-5-83 catalyst was characterized by Xray diffraction (XRD) and its XRD pattern closely resembled that of ZSM-5 (29). 


\section{Pulse reaction studies}

Three self-supporting disks of Cu-ZSM-5 (without $\mathrm{KBr}$ as diluent), each of $25 \mathrm{mg}$, were pressed by a hydraulic press at a pressure of $4000-4500$ psi. One of the disks was placed in the IR beam path in the reactor cell (30) and the two other disks were broken down into flakes and placed in close vicinity of the self-supporting disk in the reactor outlet. The additional catalyst, in the reactor outlet, was added to increase the conversion of nitric oxide and to obtain a strong signal for the reactor effluent analysis by the mass spectrometer (MS). Prior to the pulse reaction studies, the Cu-ZSM-5 catalysts were auto-reduced in flowing He at $773 \mathrm{~K}$ for $2 \mathrm{~h}$ in the in situ IR cell. The pulse reaction study, illustrated in Fig. 1, involved the use of a 6-port gas chromatograph (GC) sample injection valve (Valco Instruments Co. Inc.) for the introduction of $1 \mathrm{~cm}^{3}$ of NO into He, flowing at $45 \mathrm{~cm}^{3} / \mathrm{min}$ over the catalyst. Pulse reaction studies were carried out before and after site-poisoning to determine the adsorbate behavior and concentration of the reactor effluent with a Fourier transform infrared spectrometer (FTIR) and MS, respectively. A QMG 112 A (Balzers-Pfeiffer) MS was used to monitor the reactor effluent responses for studies over Cu-ZSM-5-83 and a Pfeiffer Prisma ${ }^{\mathrm{TM}}$ QMG 200 (Pfeiffer Vacuum Technology) MS was used for studies over Cu-ZSM-5-127. Calibration factors for each gaseous species were obtained by pulsing known amounts of gases into both the mass spectrometers. The MS profiles of each of the reactor effluent species were converted to their respective rate profiles with the help of the calibration factors. MS intensity profiles of $\mathrm{NO}_{2}$ are presented instead of the rate profiles, as the calibration factor for $\mathrm{NO}_{2}$ could not be obtained due to the lack of reliable $\mathrm{NO}_{2}$ calibration gas and a low response factor. Although $\mathrm{N}_{2} \mathrm{O}$ and $\mathrm{NO}_{2}$ formation contributes to the intensity of NO $(\mathrm{m} / \mathrm{e}=30)$, such a contribution is of the order of $\pm 2 \%$ due to the combination of low response factors for $\mathrm{N}_{2} \mathrm{O}$ and $\mathrm{NO}_{2}$ and low $\mathrm{NO}$ conversions obtained in the present study. 


\section{Site-Poisoning}

Auto-reduced Cu-ZSM-5 samples, which exhibited pulse NO decomposition activity at $673 \mathrm{~K}$, were site-poisoned by three kinds of pre-treatment: (i) water treatment; (ii) silane treatment; and (iii) sulfur dioxide treatment. Water treatment (i.e. poisoning) involved exposure of the catalyst to steam at $773 \mathrm{~K}$ for $1 \mathrm{~h}$. Silane treatment involved: (i) $\mathrm{CO}$ adsorption on $\mathrm{Cu}^{+} / \mathrm{Cu}^{2+}$ sites at $303 \mathrm{~K}$ to avoid the interaction between $\mathrm{Cu}^{+} / \mathrm{Cu}^{2+}$ sites and silane, (ii) exposure of the $\mathrm{CO}$-adsorbed catalyst to $1 \% \mathrm{SiH}_{4}$ in $\mathrm{He}$ flow at $303 \mathrm{~K}$ for $5 \mathrm{~min}$, and (iii) maintenance of the reactor under batch conditions for $1 \mathrm{~h}$ at $373 \mathrm{~K}$. Sulfur dioxide treatment involved exposure of the catalyst to $0.1 \% \mathrm{SO}_{2}$ in $\mathrm{N}_{2}$ at $373 \mathrm{~K}$ for $1 \mathrm{~h}$. Prior to each pulse reaction study, the sitepoisoned catalysts were raised to the required temperatures in He flow.

The introduction of water, silane, and sulfur dioxide into the reactor cell was monitored by collecting the background spectra of the catalyst surface before and after the pretreatment. The exposure of the catalyst to water, silane, and sulfur dioxide was verified by infrared observation of these species in the IR cell.

\section{Spreading of reactant pulse}

Figure 1 illustrates a reactant pulse input, introduced in a small amount of time (1.3 s), spreading as it moves along the length of a plug flow reactor due to turbulent mixing, velocity profile, and molecular diffusion effects (34). The extent of spreading can be characterized by the dispersion number (34). To avoid confusion with the term dispersion, used commonly to denote the metal crystal dispersion on a catalyst support, we use the term spreading in this study. The spreading of the pulse input leads to different time duration's of the pulse at different positions 
along the reactor as depicted in the case of the $1 \mathrm{~cm}^{3}$ of $\mathrm{CO}$ pulse input, in dashed lines, in Fig. 1. Correlating the adsorbate behavior from the IR spectra and gaseous MS profiles from the MS requires accounting for these differences in time duration of the $1 \mathrm{~cm}^{3}$ pulse. The time duration difference can be corrected in the case of reactions involving components that display gas phase in both the IR spectra and MS profiles. For example, pulsing $1 \mathrm{~cm}^{3}$ of $\mathrm{CO}$ into $5 \%$ NO flow produced $\mathrm{CO}_{2}$ observed in both FTIR and MS, allowing adjustment of the time scale for correlating transient response curves for the adsorbates and gaseous products involved in the reaction.

\section{RESULTS}

\section{Pulse reaction studies}

Figure 2a shows the MS rate profiles of the reactor effluent during the first two NO pulses over $\mathrm{Cu}-\mathrm{ZSM}-5-83$ in $\mathrm{He}$ at $673 \mathrm{~K}$. IR spectra taken during the first NO pulse, synchronized with the MS time scale, is shown in Fig. 2b. The time scale of the effluent MS profiles was obtained by subtracting the time required for the effluent to travel from the IR cell to the MS from the actual time scale. The pulse, after being injected, broadens as it moves down the reactor system from the IR cell to the MS due to spreading of the NO pulse in He flow. As a result, the total time span for a single NO pulse obtained from the MS profiles is 4.5 times longer than that obtained for the IR spectra (Figs. 2a and b). Due to the lack of a gaseous species that can be clearly observed by both FTIR and MS, the time span for the FTIR and MS results was not adjusted. IR spectra of gaseous NO were included in Fig. 2 for comparison with the spectra of the NO adsorbate species. 
Introduction of the NO pulse led to an increase in the $\mathrm{NO}, \mathrm{N}_{2} \mathrm{O}$, and $\mathrm{O}_{2} \mathrm{MS}$ profiles as shown in Fig. 2a. The first NO pulse, equivalent to $40.14 \mu \mathrm{mol}$, produced $1.1 \mu \mathrm{mol}$ of $\mathrm{N}_{2} \mathrm{O}$ and $0.11 \mu \mathrm{mol}$ of $\mathrm{O}_{2}$. The QMG 112A MS exhibited a very low response factor for the species with $\mathrm{m} / \mathrm{e}$ ratio of 46 , thus hampering the detection of $\mathrm{NO}_{2}$. Temperature-programmed reaction (TPR) of $5 \% \mathrm{NO}$ on Cu-ZSM-5 (33), however, produced a significant amount of $\mathrm{NO}_{2}$ at $673 \mathrm{~K}$, thus raising the possibility of $\mathrm{NO}_{2}$ formation also under pulse reaction conditions at $673 \mathrm{~K}$. Stoichiometric mass balance of the reactor inlet and outlet gaseous species for the NO pulse, obtained from the MS profiles, suggested the formation of $0.88 \mu \mathrm{mol}$ of $\mathrm{NO}_{2}$. NO decomposition on the Cu-ZSM-5-83 catalyst was accompanied by the formation of the following adsorbate species: $\mathrm{NO}^{+}, \mathrm{Cu}^{2+}(\mathrm{NO}), \mathrm{Cu}^{+}(\mathrm{NO})$, and bridging $\mathrm{Cu}^{2+}\left(\mathrm{NO}_{3}{ }^{-}\right)$as shown in Fig. $2 \mathrm{~b}$. The bridging $\mathrm{Cu}^{2+}\left(\mathrm{NO}_{3}{ }^{-}\right)$species formed as well as disappeared later than all of the observed adsorbate species. Both NO pulses produced similar MS profiles and IR spectra. The MS profiles of both NO pulses revealed a lead-lag relationship during the elution of unreacted NO, formation of $\mathrm{N}_{2} \mathrm{O}$ and $\mathrm{O}_{2} . \quad \mathrm{O}_{2}$ formation lagged behind that of $\mathrm{N}_{2} \mathrm{O}$ as well as the elution of unreacted NO.

Figure 3 shows the MS rate profiles of the reactor effluent during the first two NO pulses and the IR spectra during the first NO pulse over auto-reduced Cu-ZSM-5-127 at $673 \mathrm{~K}$. NO pulse over Cu-ZSM-5-127 produced $\mathrm{N}_{2}$ instead of $\mathrm{N}_{2} \mathrm{O}$ and a greater amount of $\mathrm{O}_{2}$ compared to the pulse over $\mathrm{Cu}-\mathrm{ZSM}-5-83$. The Prisma ${ }^{\mathrm{TM}}$ QMS $200 \mathrm{MS}$ detected $\mathrm{NO}_{2}$ formation. Comparison of NO conversion and yields during the NO pulse reaction over Cu-ZSM-5-83 and Cu-ZSM-5-127 at $673 \mathrm{~K}$, listed in Table 2, shows that the over-exchanged catalyst exhibits higher NO conversion and higher $\mathrm{O}_{2}$ yields than the under-exchanged Cu-ZSM-5. Conversion and yields of steady-state NO decomposition from our previous studies (33) are also listed in 
Table 2. Pulse reaction involved the exposure of catalyst to a smaller quantity of reactant (NO) for a shorter period of time; steady state reaction involved the exposure of catalyst to a continuous flow of reactant. Despite a significant difference in NO conversion and yields, the pulse reaction on both under- and over-exchanged catalysts produced similar adsorbates in a similar sequence except, high $\mathrm{NO}^{+}$and $\mathrm{Cu}^{2+}(\mathrm{NO})$ intensities on $\mathrm{Cu}-\mathrm{ZSM}-5-83$; high $\mathrm{Cu}^{+}(\mathrm{NO})$ and bridging $\mathrm{Cu}^{2+}\left(\mathrm{NO}_{3}{ }^{-}\right)$intensities on Cu-ZSM-5-127.

Silane, water, and sulfur dioxide site-poisoning of Cu-ZSM-5

Figure 4 shows IR spectra of $\mathrm{CO}$ adsorption at $298 \mathrm{~K}$ followed by that of $\mathrm{SiH}_{4}$ at the same temperature over auto-reduced $\mathrm{Cu}-\mathrm{ZSM}-5-83$ and $\mathrm{Cu}-\mathrm{ZSM}-5-127 . \mathrm{CO}$ adsorption produced $\mathrm{Cu}^{+}(\mathrm{CO})_{2}$ at 2153 and $2177 \mathrm{~cm}^{-1}$ (13) on both the catalysts. Subsequent addition of gaseous $\mathrm{SiH}_{4}$ produced $\mathrm{Si}-\mathrm{H}$ at $2190 \mathrm{~cm}^{-1}$ over $\mathrm{Cu}-\mathrm{ZSM}-5-83$ and at $2210 \mathrm{~cm}^{-1}$ (31) over CuZSM-5-127 in addition to the peak at $2153 \mathrm{~cm}^{-1}$. Continued exposure to $\mathrm{SiH}_{4}$ at $303 \mathrm{~K}$ caused a decrease in the intensity of (a) the $\mathrm{OH}$ groups in the $3600-3750 \mathrm{~cm}^{-1}$ region and $\mathrm{H}-\mathrm{O}-\mathrm{H}$ band at $1591 \mathrm{~cm}^{-1}$ over Cu-ZSM-5-83; (b) the OH groups in the $3600-3750 \mathrm{~cm}^{-1}$ region and $\mathrm{H}-\mathrm{O}-\mathrm{H}$ band at $1621 \mathrm{~cm}^{-1}$ over Cu-ZSM-5-127; and (c) little change in the $\mathrm{Cu}^{+}(\mathrm{CO})_{2}$ intensity over both the catalysts. Little variation in $\mathrm{Cu}^{+}(\mathrm{CO})_{2}$ signified the absence of interaction of $\mathrm{SiH}_{4}$ with the $\mathrm{Cu}^{+}$ species on the catalysts. Decrease in the $\mathrm{OH}$ intensity in the $3600-3750 \mathrm{~cm}^{-1}$ region over both Cu-ZSM-5-83 and Cu-ZSM-5-127 indicates that $\mathrm{SiH}_{4}$ reacts with the $\mathrm{H}$ of the $-\mathrm{OH}$ groups bonded to isolated silica sites, bonded by hydrogen bonding, and those present in the inside of the zeolite as shown below:

$$
-\mathrm{Si}-\mathrm{OH}+\mathrm{SiH}_{4} \rightarrow-\mathrm{Si}-\mathrm{O}-\mathrm{SiH}_{3}+\mathrm{H}_{2}
$$


Although Fig. 4 shows subtle differences in the interaction of the various hydroxyl groups with $\mathrm{SiH}_{4}$, the present study does not provide an in-depth explanation of these interactions.

Exposure of both auto-reduced catalysts (Cu-ZSM-5-83 and Cu-ZSM-5-127) to water produced $-\mathrm{OH}\left(3500-3600 \mathrm{~cm}^{-1}\right)$ and $\mathrm{H}-\mathrm{O}-\mathrm{H}\left(1620 \mathrm{~cm}^{-1}\right)$ characteristic bands in the IR spectra. Increasing the temperature to $773 \mathrm{~K}$ led to a decrease in the intensity of these bands and eventually led to their disappearance after exposure for $1 \mathrm{hr}$. Traces of $\mathrm{H}_{2} \mathrm{O}$ left in the IR cell were removed by flushing with $\mathrm{He}$ at $773 \mathrm{~K}$.

Sulfur dioxide $\left(0.1 \% \mathrm{SO}_{2}\right.$ in $\left.\mathrm{N}_{2}\right)$ exposure of the catalysts at $303 \mathrm{~K}$ did not cause a change in their IR spectra. S-O bands $\left(1000-1200 \mathrm{~cm}^{-1}\right)$ could not been observed due to the low concentration of $\mathrm{SO}_{2}$ and cut-off of IR radiation below $1200 \mathrm{~cm}^{-1}$ by the $\mathrm{CaF}_{2}$ rods and windows used in the IR cell. The reactor was operated in the batch mode by heating to $373 \mathrm{~K}$. Subsequently, $\mathrm{SO}_{2}$ was flushed out of the IR cell by flowing $\mathrm{He}$ at $373 \mathrm{~K}$.

\section{Pulse reaction studies on site-poisoned catalyst}

Figure 5 compares the MS intensity profiles of the reactor effluents and IR spectra during the NO pulses over auto-reduced (Figs. 5a and b), silane-treated (Figs. 5c and d), water-treated (Figs. 5e and f), and sulfur dioxide-treated (Figs. 5g and h) Cu-ZSM-5-83 at $673 \mathrm{~K}$. Sitepoisoning decreased $\mathrm{N}_{2} \mathrm{O}$ formation by a factor of 2 with silane, 2.5 with water, and completely suppressed $\mathrm{N}_{2} \mathrm{O}$ formation with sulfur dioxide; decreased $\mathrm{O}_{2}$ formation by a factor of 4 with water, and completely suppressed $\mathrm{O}_{2}$ formation with silane and sulfur dioxide (Figs. 5a, c, e, and g). Infrared spectra show the consistent suppression of $\mathrm{Cu}^{+}(\mathrm{NO})$ and bridging $\mathrm{Cu}^{2+}\left(\mathrm{NO}_{3}\right)^{-}$ species over all the site-poisoned catalysts (Figs. $5 b, d, f$, and $h$ ). Water treatment caused an increase in $\mathrm{Cu}^{2+} \mathrm{O}^{-} \mathrm{NO}$ ) and sulfur dioxide treatment led to an increase of $\mathrm{NO}^{+}$. 
The MS intensity profiles of the reactor effluents and IR spectra during the NO pulses over auto-reduced (Figs. 6a and b), silane-treated (Figs. 6c and d), water-treated (Figs. 6e and f), and sulfur dioxide-treated (Figs. $6 \mathrm{~g}$ and $\mathrm{h}$ ) Cu-ZSM-5-127 at $673 \mathrm{~K}$ are shown in Fig. 6. Similar to the under exchanged Cu-ZSM-5, site-poisoning of the over-exchanged catalyst decreased $\mathrm{O}_{2}$ formation by a factor of 20 with water and completely suppressed $\mathrm{O}_{2}$ formation with silane and sulfur dioxide. Site-poisoning also decreased $\mathrm{N}_{2}$ formation by a factor of 4.6 with silane, 5.8 with water, and completely suppressed $\mathrm{N}_{2}$ formation with sulfur dioxide (Figs. 6a, c, e, and g). Infrared spectra of $\mathrm{Cu}-\mathrm{ZSM}-5-127$ showed that site-poisoning suppressed $\mathrm{Cu}^{+}(\mathrm{NO})$ and bridging $\mathrm{Cu}^{2+}\left(\mathrm{NO}_{3}{ }^{-}\right)$species over all the pretreated catalysts analogous to that over Cu-ZSM-5-83. Silane treatment also decreased the formation of $\mathrm{NO}^{+}$species (Figs. $6 \mathrm{~b}, \mathrm{~d}, \mathrm{f}$, and $\mathrm{h}$ ). Table 3 shows the NO conversion and yields as well as variation in the IR intensity of adsorbates during the NO pulses over site-poisoned Cu-ZSM-5 catalysts at $673 \mathrm{~K}$.

The Cu-ZSM-5-83 and Cu-ZSM-5-127 site-poisoned catalysts, exposed to NO pulse reaction studies at $673 \mathrm{~K}$, were subsequently also subjected to similar pulse reaction studies at 723 and $773 \mathrm{~K}$. Increase in temperature from $673 \mathrm{~K}$ to 723 and $773 \mathrm{~K}$ did not change the rate of product formation.

Zeolite analysis before/after site-poisoning and pulse studies

Figures 7 and 8 compare the transmission spectra, in the framework adsorption region, of auto-reduced, silane-, water-, and sulfur dioxide-pretreated Cu-ZSM-5-83 and Cu-ZSM-5-127, respectively, under ambient conditions after the pulse studies. The transmission spectra were obtained by taking the ratio of (a) the spectrum of the pellet obtained from a mixture of the catalyst and $\mathrm{KBr}$ and (b) the spectrum of the pellet obtained from $\mathrm{KBr}$ alone. The catalyst and 
$\mathrm{KBr}$ mixture was composed of $99.75 \% \mathrm{KBr}$ and $0.25 \% \mathrm{Cu}-\mathrm{ZSM}-5(0.5 \mathrm{mg} \mathrm{Cu}-\mathrm{ZSM}-5$ in 200 $\mathrm{mg} \mathrm{KBr}$ ). The pellet made from the auto-reduced sample showed internal vibrations of the $\mathrm{Si}$ and $\mathrm{AlO}_{4}$ tetrahedra at 1092 and $453 \mathrm{~cm}^{-1}$ and vibrations of the double-ring tetrahedra at $550 \mathrm{~cm}^{-}$ 1. The position of the band at $550 \mathrm{~cm}^{-1}$ characterized the presence of a ZSM-5 framework in the zeolite (32). The intensity ratio of the 550 to $453 \mathrm{~cm}^{-1}$ bands was not affected by the NO pulse, as shown in Figs. 7 and 8, as well as by site-poisoning, indicating that ZSM-5 maintained its framework during the site-poisoning and pulse reaction studies.

\section{DISCUSSION}

Direct NO decomposition on the Cu-ZSM-5 catalyst has been studied extensively (1022). However, few have reported the IR spectra of NO adsorbates on Cu-ZSM-5 exhibiting NO decomposition activity. The NO decomposition activity of Cu-ZSM-5 is sensitive to reaction conditions and dependent on copper loading and $\mathrm{Si} / \mathrm{Al}$ ratio. Hence, observations from separate adsorption and activity studies can not be directly applicable to the identification of active adsorbate species and formulation of a reaction pathway. The present study simultaneously measured the catalyst activity and dynamic behavior of the adsorbate species during the NO decomposition reaction under pulse reaction conditions on auto-reduced, site-poisoned, and COpromoted $\mathrm{Cu}-\mathrm{ZSM}-5$ catalyst. Interpretation of adsorbate and reactant/product concentration profile results requires recognition of the facts that: (i) adsorbate formation reflects the availability of sites to which the adsorbates are bound; and (ii) increase in adsorbate profile indicates the rate of adsorbate formation being greater than its destruction (i.e., desorption or conversion to other species) rate. 
Over- and under-exchanged Cu-ZSM-5

Pulse and steady-state reaction studies (Table 2) show that over-exchanged Cu-ZSM-5 exhibits higher NO decomposition activity and higher $\mathrm{N}_{2}$ selectivity than the under-exchanged catalyst. Cu-ZSM-5-83, however, exhibited higher $\mathrm{N}_{2} \mathrm{O}$ selectivity compared to that of $\mathrm{Cu}-$ ZSM-5-127. The results are consistent with earlier reported studies $(27,40,41)$. Despite differences in $\mathrm{NO}$ activity, $\mathrm{N}_{2}$ and $\mathrm{N}_{2} \mathrm{O}$ selectivity, the over- and under-exchanged Cu-ZSM-5 catalysts interact with NO to form the same IR-observable adsorbates and display similar adsorbate dynamics under reaction conditions (Figs. 2 and 3). The only difference was that $\mathrm{Cu}^{2+}\left(\mathrm{NO}_{3}{ }^{-}\right)$on Cu-ZSM-5-127 grew and decayed much faster than that on Cu-ZSM-5-127 during step reaction studies (33). The similarity in adsorbate structure and behavior over two catalysts with different activity and selectivity suggests that these IR-observable adsorbates may not participate in the rate-limiting step for reactant conversion and for product formation.

The adsorbate and reaction product profiles follow a sequence of formation during the pulse reaction studies (Figs. 2 and 3 ) and step switch reaction studies (33). $\mathrm{Cu}^{+}(\mathrm{NO})$ and $\mathrm{Cu}^{2+}(\mathrm{NO})$ precede the formation of bridging $\mathrm{Cu}^{2+}\left(\mathrm{NO}_{3}{ }^{-}\right)$while $\mathrm{N}_{2} / \mathrm{N}_{2} \mathrm{O}$ precede that of $\mathrm{O}_{2}$. The sequence of product and adsorbate formation allows postulation of the following reaction pathways.

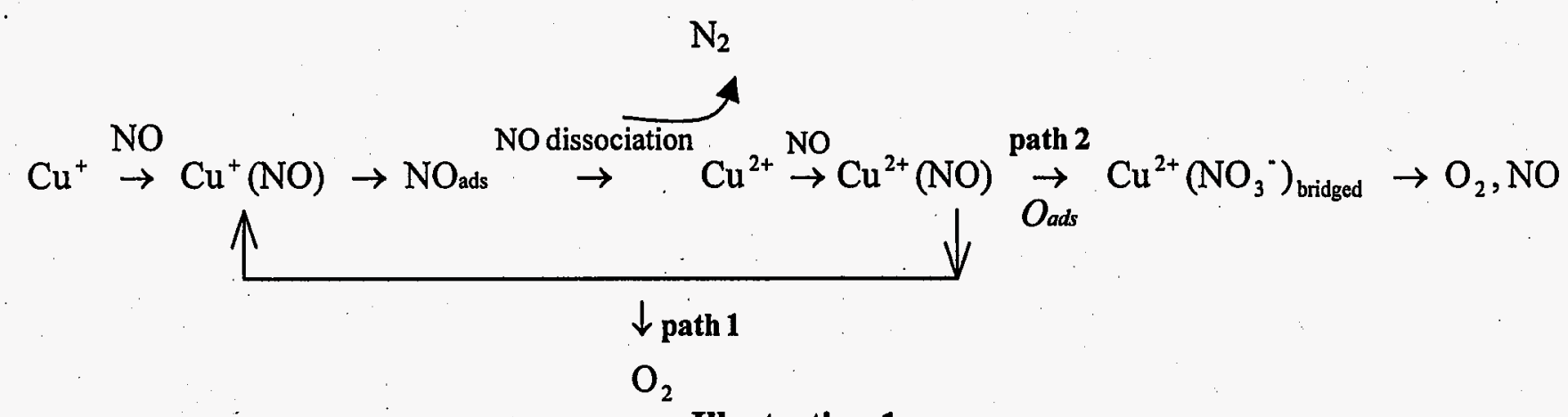

Illustration 1 
Despite the lack of direct correlation between $\mathrm{N}_{2} \mathrm{O}$ formation and intensity of $\mathrm{Cu}^{+}(\mathrm{NO})$ on the under-exchanged $\mathrm{Cu}-\mathrm{ZSM}-5$ (Figs. 5a-5h), $\mathrm{N}_{2}$ formation rate appears to correlate with $\mathrm{Cu}^{+}(\mathrm{NO})$ on the over-exchanged catalyst (Figs. 6a-6h). The close proximity in the evolution sequence of $\mathrm{N}_{2}$ and $\mathrm{N}_{2} \mathrm{O}$ with that of $\mathrm{Cu}^{+}(\mathrm{NO})$ (Figs. 2 and 3) allows consideration of $\mathrm{Cu}^{+}(\mathrm{NO})$ as not being directly involved, but as being in the path of $\mathrm{NO}$ dissociation and $\mathrm{N}_{2}$ formation. In the event of $\mathrm{Cu}^{+}(\mathrm{NO})$ being a direct precursor for $\mathrm{N}_{2} / \mathrm{N}_{2} \mathrm{O}$ formation, the concentration of reaction intermediates $\left(\mathrm{Cu}^{+}(\mathrm{NO})\right)$ preceding the products $\left(\mathrm{N}_{2} / \mathrm{N}_{2} \mathrm{O}\right)$ is expected to decrease prior to increase in the product concentration under pulse transient conditions. Since, this is not the case, the supposition that $\mathrm{Cu}^{+}(\mathrm{NO})$ is indirectly involved in $\mathrm{N}_{2} \mathrm{~N}_{2} \mathrm{O}$ formation is valid. $\mathrm{Cu}^{+}(\mathrm{NO})$ could be a precursor for the formation of an intermediate species which in turn would be a precursor for NO dissociation. The reaction step involving the formation of such an intermediate are not within the detection limits of the IR/MS spectrometer reaction systems used in the present study. Therefore, $\mathrm{NO}_{\mathrm{ads}}$ is arbitrarily placed in the reaction pathway leading to NO dissociation as shown in Illustration 1.

One possible pathway (path 1) for $\mathrm{O}_{2}$ formation is the auto-reduction of Cu-ZSM-5 that

reduces $\mathrm{Cu}^{2+}$ to $\mathrm{Cu}^{+}$and releases $\mathrm{O}_{2}$. First principle quantum mechanical calculations (39) further supported the occurrence of path 1 by suggesting that $\mathrm{Cu}^{2+}$ species $(\mathrm{CuO})$ reduced to $\mathrm{Cu}^{+}$ producing $\mathrm{O}_{2}$. The other pathway (path 2), involving $\mathrm{Cu}^{2+}\left(\mathrm{NO}_{3}{ }^{-}\right)$, will be further elaborated in the following sections.

\section{Site-poisoning}

Absence of $\mathrm{O}_{2}$ and bridging $\mathrm{Cu}^{2+}\left(\mathrm{NO}_{3}{ }^{-}\right)$on the site-poisoned catalysts suggests that both $\mathrm{O}_{2}$ and bridging $\mathrm{Cu}^{2+}\left(\mathrm{NO}_{3}{ }^{-}\right)$be produced from the same precursor whose formation has been 
inhibited by the poisoning. The formation of this precursor requires the migration of adsorbed oxygen available from the NO dissociation site that remains to be further investigated. Bridging $\mathrm{Cu}^{2+}\left(\mathrm{NO}_{3}{ }^{-}\right)$has been shown to decompose to $\mathrm{N}_{2}, \mathrm{NO}$, and $\mathrm{O}_{2}$ under temperature-programmed reaction conditions (33). However, it is unclear whether bridging $\mathrm{Cu}^{2+}\left(\mathrm{NO}_{3}{ }^{-}\right)$would serve as a major precursor for $\mathrm{O}_{2}$ formation under steady-state and pulse NO decomposition conditions.

Regardless of the proposed pathway (path 1 or 2), site-poisoning by $\mathrm{SiH}_{4}, \mathrm{H}_{2} \mathrm{O}$, and $\mathrm{SO}_{2}$ inhibited bridging $\mathrm{Cu}^{2+}\left(\mathrm{NO}_{3}{ }^{-}\right)$and $\mathrm{O}_{2}$ as well as auto reduction of $\mathrm{Cu}^{2+}$ to $\mathrm{Cu}^{+}$. In contrast, $\mathrm{N}_{2}$ and $\mathrm{N}_{2} \mathrm{O}$ formation were suppressed to different extents, depending on the type of poisoning. The significant difference in suppression of $\mathrm{O}_{2}$ and $\mathrm{N}_{2}$ formation brought about by site-poisoning indicates that $\mathrm{NO}$ dissociation is not a common rate-limiting step for both $\mathrm{N}_{2}$ and $\mathrm{O}_{2}$ formation. The rate-limiting step for $\mathrm{N}_{2}$ formation should locate between the final $\mathrm{N}_{2}$ formation step and $\mathrm{Cu}^{+}(\mathrm{NO})$ conversion step.

\section{Reaction mechanism}

The NO decomposition reaction can be further expanded into a detailed pathway that includes all the observable adsorbates as shown in Fig. 9. NO adsorbs on the $\mathrm{Cu}^{+}$site to form $\mathrm{Cu}^{+}(\mathrm{NO})$ as reported in earlier studies (13-19) and also shown in the present study in Figs. 2 and

3. NO dissociation has been envisioned to occur via three routes: (i) reaction of neighboring $\mathrm{Cu}^{+}(\mathrm{NO})$ species alone or with $\mathrm{Cu}^{+}(\mathrm{NO})_{2}$ to produce $\mathrm{N}_{2} / \mathrm{N}_{2} \mathrm{O}$ and $\mathrm{Cu}^{2+} \mathrm{O}$ (14); (ii) dissociation of $\mathrm{Cu}^{+}(\mathrm{NO})_{2}$ to produce $\mathrm{Cu}^{2+} \mathrm{O}^{-}$and $\mathrm{N}_{2} \mathrm{O}(13,15,16)$; and (iii) conversion of $\mathrm{Cu}^{+}(\mathrm{NO})_{2}$ to $\mathrm{Cu}^{2+}\left(\mathrm{N}_{2} \mathrm{O}_{3}{ }^{-}\right)$which dissociates to form $\mathrm{N}_{2}, \mathrm{~N}_{2} \mathrm{O}$, and $\mathrm{O}_{2}(17,19)$. Although the $\mathrm{Cu}^{+}(\mathrm{NO})_{2}$ has been proposed as a precursor for $\mathrm{N}_{2} \mathrm{O}$ formation according to $\mathrm{Cu}$ (nitrosyl) chemistry $(13,15-16)$, the lack of correlation between $\mathrm{Cu}^{+}(\mathrm{NO})_{2}$ and $\mathrm{N}_{2}$ formation (33) and first principles quantum 
mechanical calculations (39) suggest that $\mathrm{Cu}^{+}(\mathrm{NO})_{2}$ is not formed under reaction conditions. Thus, $\mathrm{Cu}^{+}(\mathrm{NO})_{2}$ as a precursor is ruled out. Results from the present IR studies suggest that the rate-limiting step for $\mathrm{NO}$ dissociation is located between $\mathrm{Cu}^{+}(\mathrm{NO})$ and $\mathrm{N}_{2}$ formation. The role of $\mathrm{Cu}^{+}(\mathrm{NO})$ as a precursor for $\mathrm{N}_{2} \mathrm{O}$ and $\mathrm{N}_{2}$ formation has been reported earlier as shown in path IIII (Fig. 9) (14,20,39).

The first two steps of path III can be used to explain the formation of $\mathrm{N}_{2} \mathrm{O}$ on the underexchanged Cu-ZSM-5 while the third step may explain $\mathrm{N}_{2}$ formation on the over-exchanged $\mathrm{Cu}$ ZSM-5. The lack of $\mathrm{N}_{2} \mathrm{O}$ formation on over-exchanged Cu-ZSM-5 suggests that $\mathrm{N}_{2} \mathrm{O}$ would not desorb from the surface to the gas phase and the life time of $\mathrm{N}_{2} \mathrm{O}$ would be shorter than that detectable by the FTIR.

Subsequent NO adsorption on $\mathrm{Cu}^{2+} \mathrm{O}_{2}^{-}$produced $\mathrm{Cu}^{2+} \mathrm{O}^{-}(\mathrm{NO})$ (step 3) whose presence during NO reaction conditions has been reported in literature (13). The coordination and charge balance for the formation of $\mathrm{Cu}^{2+} \mathrm{O}_{2}^{-}$remains to be investigated. $\mathrm{O}_{2}$ formation beyond $\mathrm{Cu}^{2+} \mathrm{O}^{-}$ (NO) may proceed via (a) auto-reduction of $\mathrm{Cu}^{2+}$ to $\mathrm{Cu}^{+}$to release $\mathrm{O}_{2}$ (step 3a) and (b) formation and subsequent decomposition of $\mathrm{Cu}^{2+}\left(\mathrm{NO}_{3}{ }^{-}\right)$to $\mathrm{N}_{2}, \mathrm{O}_{2}, \mathrm{~N}_{2} \mathrm{O}$, and $\mathrm{NO}$ (steps 4 and 5). The $\mathrm{O}_{2}$ formation steps are the most sensitive to surface modification. Even though $\mathrm{Cu}^{+} / \mathrm{Cu}^{2+}$ were not modified by silane, modification of the $\mathrm{Cu}^{2+}-\mathrm{O}_{-} \mathrm{Cu}^{2+}$ site caused the inhibition of $\mathrm{O}_{2}$ desorption/formation on the silane-poisoned Cu-ZSM-5.

\section{Deactivation}

Using Fig. 9 as the working NO decomposition mechanism, the susceptibility of each step in the pathway to site-poisoning, on the basis of the effect of poison on adsorbate intensity and product amount, can be summarized as follows: 
Step 1: Moderately poisoned by $\mathrm{SiH}_{4}$ and slightly poisoned by $\mathrm{SO}_{2}$ and $\mathrm{H}_{2} \mathrm{O}$ on underexchanged Cu-ZSM-5; moderately poisoned by $\mathrm{SO}_{2}$ and slightly poisoned by $\mathrm{H}_{2} \mathrm{O}$ and $\mathrm{SiH}_{4}$ on over-exchanged Cu-ZSM-5.

Step 2: $\quad$ Moderately poisoned by $\mathrm{SiH}_{4}$ and $\mathrm{H}_{2} \mathrm{O}$ and completely poisoned by $\mathrm{SO}_{2}$ on both the under- and over-exchanged Cu-ZSM-5.

Step 3a: Significantly poisoned by $\mathrm{SiH}_{4}, \mathrm{H}_{2} \mathrm{O}$, and $\mathrm{SO}_{2}$ on both the under- and overexchanged Cu-ZSM-5.

Step 4: Completely poisoned by $\mathrm{SiH}_{4}, \mathrm{H}_{2} \mathrm{O}$, and $\mathrm{SO}_{2}$ on both the under- and overexchanged Cu-ZSM-5.

Severe inhibition of $\mathrm{O}_{2}$ formation by $\mathrm{SiH}_{4}, \mathrm{H}_{2} \mathrm{O}$, and $\mathrm{SO}_{2}$ poisoning shows that $\mathrm{O}_{2}$ formation is the most fragile step. The presence of weak $\mathrm{Cu}^{+}(\mathrm{NO})$ and $\mathrm{Cu}^{2+}(\mathrm{NO})$ with nearcomplete suppression of bridging $\mathrm{Cu}^{2+}\left(\mathrm{NO}_{3}{ }^{-}\right)$and $\mathrm{O}_{2}$ formation suggested that blocking of $\mathrm{Cu}^{+}$ and $\mathrm{Cu}^{2+}$ site is not the major deactivation pathway for $\mathrm{O}_{2}$. Instead, inhibiting the migration of adsorbed oxygen for the formation of $\mathrm{O}_{2}$ and bridging $\mathrm{Cu}^{2+}\left(\mathrm{NO}_{3}{ }^{-}\right)$is the dominant deactivation mechanism. A study of adsorbed oxygen on Cu-ZSM-5 is currently underway to reveal the oxygen formation pathway. The observation of $\mathrm{N}_{2}$ and $\mathrm{N}_{2} \mathrm{O}$, even with low rate of formation on the site-poisoned catalysts shows that NO dissociation and N-N formation is more facile than $\mathrm{O}_{2}$ formation and less severely inhibited by poisoning.

Spectator vs active adsorbates

Significant inhibition of $\mathrm{NO}^{+}$formation on $\mathrm{SiH}_{4}$-poisoned Cu-ZSM-5 (Figs. 5d and 6d) and increase of $\mathrm{NO}^{+}$formation on $\mathrm{SO}_{2}$-poisoned Cu-ZSM-5 (Figs. $5 \mathrm{~h}$ and $6 \mathrm{~h}$ ) combined with the complete inhibition of $\mathrm{O}_{2}$ formation (Figs. $5 \mathrm{c}, 5 \mathrm{~g}, 6 \mathrm{c}$, and $6 \mathrm{~g}$ ) indicates that the site on which 
$\mathrm{NO}^{+}$adsorbs does not play an active role in $\mathrm{O}_{2}$ formation. Thus, $\mathrm{NO}^{+}$is a spectator adsorbate during the $\mathrm{NO}$ decomposition to $\mathrm{N}_{2}$ and $\mathrm{O}_{2}$.

$\mathrm{Cu}^{+}(\mathrm{NO})$, though not a direct precursor, is in the pathway leading to $\mathrm{N}_{2} / \mathrm{N}_{2} \mathrm{O}$ formation; $\mathrm{Cu}^{2+}\left(\mathrm{NO}_{3}{ }^{-}\right)$, always accompanied by $\mathrm{O}_{2}$ formation, decomposes to $\mathrm{N}_{2}, \mathrm{O}_{2}, \mathrm{~N}_{2} \mathrm{O}$, and $\mathrm{NO}$ during the NO decomposition reaction. Hence, $\mathrm{Cu}^{+}(\mathrm{NO})$ and $\mathrm{Cu}^{2+}\left(\mathrm{NO}_{3}{ }^{-}\right)$are the active adsorbates for the NO decomposition reaction to $\mathrm{N}_{2}$ and $\mathrm{O}_{2}$ over Cu-ZSM-5.

\section{$\mathrm{SiH}_{4}$ pretreatment}

Our initial goal for $\mathrm{SiH}_{4}$ treatment of $\mathrm{Cu}-\mathrm{ZSM}-5$ was to improve the catalyst hydrothermal stability by the removal of surface $\mathrm{OH}$ groups on $\mathrm{ZSM}-5$. $\mathrm{SiH}_{4}$ has been used as a precursor for the pore size modification of zeolites that also exhibited good thermal and water resistance $(37,38)$. The present study (Fig. 4) shows that $\mathrm{SiH}_{4}$ reacts with and removes the surface hydroxyl group; and also poisoned NO decomposition activity. As a result, silanation can not be used to improve hydrothermal stability of Cu-ZSM-5 for NO decomposition.

\section{CONCLUSIONS}

Direct NO decomposition reaction over Cu-ZSM-5 serves as a model reaction for sitepoisoning and -promotion technique. Site-poisoning and -promotion studies shed new light into the NO decomposition reaction mechanism. $\mathrm{O}_{2}$ formation/desorption pathway proceeds via two routes: (a) auto-reduction of $\mathrm{Cu}^{2+}$ to $\mathrm{Cu}^{+}$followed by desorption of $\mathrm{O}_{2}$ and (b) decomposition of $\mathrm{Cu}^{2+}\left(\mathrm{NO}_{3}{ }^{\circ}\right)$ to $\mathrm{N}_{2}, \mathrm{O}_{2}, \mathrm{~N}_{2} \mathrm{O}$ and $\mathrm{NO} . \mathrm{Cu}^{+}(\mathrm{NO})$ and $\mathrm{Cu}^{2+}\left(\mathrm{NO}_{3}{ }^{-}\right)$act as active adsorbates while $\mathrm{NO}^{+}$acts as a spectator adsorbate during the NO decomposition to $\mathrm{N}_{2}$ and $\mathrm{O}_{2}$. 
$\mathrm{SiH}_{4}, \mathrm{H}_{2} \mathrm{O}$, and $\mathrm{SO}_{2}$ severely poison $\mathrm{O}_{2}$ formation but do not inhibit $\mathrm{NO}$ dissociation and $\mathrm{N}_{2}$ formation. Inhibition of adsorbed $\mathrm{O}$ migration is the dominant deactivation pathway for $\mathrm{O}_{2}$ formation/desorption rather than the blockage of $\mathrm{Cu}^{+}$and $\mathrm{Cu}^{2+}$ sites. 


\section{References}

(1) Tamaru, K., Dynamic Relaxation Methods in Heterogeneous Catalysis, in "Catalysis: Science and Technology", (Anderson, J. R. and Boudart, M., Eds.), vol. 9, p. 87. Springer-Verlag, Berlin-Heidelberg-New York, 1991.

(2) Delgass, W. N., Haller, G. L., Kellerman, R., and Lunsford, J. H., "Spectroscopy in Heterogeneous Catalysis", Academic Press, New York, 1979.

(3) Srinivas, G., Chuang, S. S. C., and Debnath, S., J. Catal. 148, 748 (1994).

(4) Yamada, T., Onishi, T., and Tamaru, K., Surf. Sci. 157, L389 (1985).

(5) Lombardo, S. J. and Bell, A. T., Surf. Sci. 245, 213 (1991).

(6) Chuang, S. S. C., Krishnamurthy, R., and Tan, C. D., Colloids and Surf. A 105, 35 (1995).

(7) Shido, T. and Iwasawa, Y., J. Catal. 141, 71 (1993).

(8) Akhter, S. and White, J. M., J. Vac. Sci. Tech. A 6, 864 (1988).

(9) Ceyer, C. T., Langmuir 6, 82 (1990).

(10) Iwamoto, M., Yoko, S., Sakai, K., and Kagawa, S., J. Chem. Soc. Faraday Trans. 1, 77, 1629 (1981).

(11) Iwamoto, M., Furukawa, H., and Kagawa, S., in "New Developments in Zeolite Science and Technology" (Murukama, Y., Ichijima, A., and Ward, J. W., Eds.), p 943. Elsevier, Amsterdam, 1986.

(12) Li, Y. and Hall, W. K., J. Phys. Chem. 94, 6145 (1990).

(13) Aylor, A. W., Larsen, S. C., Reimer, J. A. and Bell, A. T., J. Catal. 157, 592 (1995).

(14) Iwamoto, M., Yahiro, H., Mizuno, N., Zhang, W. -X., Mine, Y., Furukawa, H. and Kagawa, S., J. Phys. Chem. 96, 9360 (1992).

(15) Giamello, E., Murphy, D., Magnacca, G., Morterra, C., Shioya, Y., Nomura, T., and Anpo, M., J. Catal. 136, 510 (1992). 
(16) Valyon, J. and Hall, W. K., in "New Frontiers in Catalysis", Proceedings of the $10^{\text {th }}$ International Congress on Catalysis, 1992 (Guczi, L., Solymosi, F., Tetenyi, P., Ed.), p 1341, Akademiai Kiado: Budapest, Hungary, 1993.

(17) Spoto, G., Zecchina, A., Bordiga, S., Ricchiardi, G., Marta, G. Leofanti, G., and Petrini, G., Appl. Catal B: Environmental 3, 151 (1994).

(18) Hoost, T. B., Laframboise, K. A., and Otto, K., Catal. Lett. 33, 105 (1995).

(19) Cheung, T., Bhargava, S. K., Hobday, M., and Foger, K., J. Catal 158, 301 (1996).

(20) Adelman, B. J., Beutel, T., Lei, G. -D., and Sachtler, W. M. H., J. Catal. 158, 327 (1996).

(21) Hadjiivanov, K., Saussey, J., Freysz, J. L., and Lavalley, J. C., Catal. Lett. 52, 103 (1998).

(22) Jang, H. -J., Hall, W. K., d'Itri, J. L., J. Phys. Chem. 100, 9416 (1996).

(23) Nakamoto, K., Fujita, J., and Murata, H., J. Amer. Chem. Soc. 80, 4817 (1958).

(24) Cleare, M. J. and Griffith, W. P., J. Chem. Soc. (A) 1144 (1967).

(25) Pozdnyakov, D. V. and Filiminov, V. N., Kinetics and Catalysis 14, 655 (1973).

(26) Addison, C. C. and Gatehouse, B. M., J. Chem. Soc. 613 (1960).

(27) Iwamoto, M., Yahiro, H., Tanda, K., Mizuno, N., Mine, Y., and Kagawa, S., J. Phys. Chem. 95, 3727 (1991).

(28) Leyden, D. E., "Silanes, Surfaces, and Interfaces", Gordon and Breach, New York, 1985.

(29) Chuang, S. S. C. and Lopez, B., in "Progress in Zeolite and Microporous Materials", Studies in Surface Science and Catalysis (Chon, H., Ihm, S. -K., and Uh, Y. S. Eds.), vol. 105, p 1477 (1995).

(30) Chuang, S. S. C., Brundage, M. A., Balakos, M., and Srinivas, G., Appl. Spectrosc. 49 (8), 1151 (1995).

(31) Silverstein, R. M., Bassler, G. C., and Morrill, T. C., "Spectrometric Identification of Organic Compounds", John Wiley and Sons, New York, p130 (1991).

(32) Coudurier, G., Naccache, C., and Vedrine, J. C., J. Chem. Soc., Chem. Commun. 1413 (1982).

(33) Konduru, M. V. and Chuang, S. S. C., J. Phys. Chem.:B (submitted). 
(34) Levenspiel, O., "Chemical Reaction Engineering", John Wiley and Sons, New York, p293-296 (1999).

(35) Hadjiivanov, K., Klissurski, D., Ramis, G., and Busca, G., Appl. Catal. B: Environmental 7, 251 (1996).

(36) Yamashita, H., Matsuoka, M., Tsuji, K., Shioya, Y., Anpo, M., and Che, M., J. Phys. Chem. 100, 397 (1996).

(37) Thijs, A., Peeters, G., Vansant, E. F., and Verhaert, I., J. Chem. Soc., Faraday Trans. 79, 2821 (1983).

(38) Choplin, A., J. Mol. Catal. 86, 501 (1994).

(39) Trout, B. L., Chakraborty, A. K., and Bell, A. T., J. Phys. Chem. 100, 17582 (1996).

(40) Pirone, R., Giambelli, P., Moretti, G., and Russo, G., Appl. Catal. B: Environmental 8, 197 (1996).

(41) Li, Y., and Hall, W. K., J. Catal. 129, 202 (1991).

(42) Konduru, M. V. PhD preliminary research, The University of Akron (1999). 


\section{List of Figures}

Figure 1 Experimental setup during NO pulse and CO pulse reaction studies; the dashed pulse responses indicate the change in duration times due to spreading.

Figure 2 (a) MS rate profiles of the reactor effluents during the $1^{\text {st }}$ and $2^{\text {nd }} 1 \mathrm{~cm}^{3} \mathrm{NO}$ pulses in He and (b) FTIR rapid scan spectra during the $1^{\text {st }}$ NO pulse, at $673 \mathrm{~K}$ over autoreduced Cu-ZSM-5-83.

Figure 3 (a) MS rate profiles of the reactor effluents during the $1^{\text {st }}$ and $2^{\text {nd }} 1 \mathrm{~cm}^{3}$ NO pulses in He and (b) FTIR rapid scan spectra during the $1^{\text {st }}$ NO pulse, at $673 \mathrm{~K}$ over autoreduced $\mathrm{Cu}-\mathrm{ZSM}-5-127$.

Figure 4 FTIR spectra of (a) Cu-ZSM-5-83, (b) Cu-ZSM-5-127 after flowing 5\% CO and flushing with $\mathrm{He}$ at $298 \mathrm{~K}, 1 \% \mathrm{SiH}_{4}$ in $\mathrm{He}$ flow for $30 \mathrm{~min}$ at $298 \mathrm{~K}$, subsequent He flush, and heating the catalyst to $373 \mathrm{~K}$.

Figure 5 MS intensity profiles of the reactor effluents during a $1 \mathrm{~cm}^{3}$ NO pulse over (a) auto-reduced, (c) silane-treated, (e) water-treated, and (g) sulfur dioxide-treated Cu-ZSM-5-83; IR spectra during NO pulse over (b) auto-reduced, (d) silanetreated, (f) water-treated, and (h) sulfur dioxide treated Cu-ZSM-5-83 at $673 \mathrm{~K}$.

Figure 6 MS intensity profiles of the reactor effluents during a $1 \mathrm{~cm}^{3} \mathrm{NO}$ pulse over (a) auto-reduced, (c) silane-treated, (e) water-treated, and (g) sulfur dioxide-treated Cu-ZSM-5-127; IR spectra during NO pulse over (b) auto-reduced, (d) silanetreated, $(f)$ water-treated, and $(\mathrm{h})$ sulfur dioxide treated $\mathrm{Cu}-\mathrm{ZSM}-5-127$ at $673 \mathrm{~K}$.

Figure 7 FTIR transmission spectra of Cu-ZSM-5-83 after pretreatment by (a) autoreduction, (b) $1 \%$ silane, (c) water, and (d) $0.1 \%$ sulfur dioxide.

Figure 8 FTIR transmission spectra of Cu-ZSM-5-127 after pretreatment by (a) autoreduction, (b) $1 \%$ silane, (c) water, and (d) $0.1 \%$ sulfur dioxide.

Figure 9 Proposed NO decomposition reaction mechanism 
Table 1 Composition of the Cu-ZSM-5 catalysts used in the present study

\begin{tabular}{ccc}
\hline & Cu-ZSM-5-83 & Cu-ZSM-5-127 \\
\hline $\mathrm{Si} / \mathrm{Al}$ & 24.4 & 24.4 \\
$\mathrm{Cu} / \mathrm{Al}$ & 0.415 & 0.675 \\
$\%$ copper exchange & 83 & 127 \\
\hline
\end{tabular}


Table 2 NO conversion and yields during steady state NO flow $\left(2.5 \mathrm{~cm}^{3} / \mathrm{min}\right.$ NO and $\left.47.5 \mathrm{~cm}^{3} / \mathrm{min} \mathrm{He}\right)$ and pulse $N O\left(1 \mathrm{~cm}^{3}\right.$ into $\left.47.5 \mathrm{~cm}^{3} / \mathrm{min} \mathrm{He}\right)$ decomposition over Cu-ZSM-5-83 (0.101 g) and Cu-ZSM-5-127 (0.103 g) at $673 \mathrm{~K}$

\begin{tabular}{ccccc}
\hline & \multicolumn{2}{c}{ Cu-ZSM-5-83 } & \multicolumn{2}{c}{ Cu-ZSM-5-127 } \\
\hline Conversion (\%) & Steady State & Pulse & Steady State & Pulse \\
\hline NO & 14.7 & 7.2 & 21.1 & 20.4 \\
& $(2.4)^{\mathrm{a}}$ & & $(3.4)^{\mathrm{a}}$ & \\
Yields (\%) & & & & \\
$\frac{\text { moles of } \mathrm{N}_{2} \text { produced }}{\text { moles of } \mathrm{NO} \text { converted }}$ & 0 & 0 & 40.5 & 29.7 \\
$\frac{\text { moles of } \mathrm{O}_{2} \text { produced }}{\text { moles of NO converted }}$ & 0.2 & 3.4 & 3.7 & 9.5 \\
$\begin{array}{c}\text { moles of } \mathrm{N}_{2} \mathrm{O} \text { produced } \\
\text { moles of } \mathrm{NO}_{\text {converted }}\end{array}$ & 16.5 & 35.6 & 0 & 0 \\
$\begin{array}{c}\text { moles of } \mathrm{NO}_{2} \text { produced } \\
\text { moles of } \mathrm{NO}_{\text {converted }}\end{array}$ & 67.2 & 40.5 & 18.5 & 28.8 \\
\hline
\end{tabular}

a rate of NO conversion $(\mu \mathrm{mol} / \mathrm{sec} . \mathrm{g})$ 
Table 3 NO conversion and yields (moles of product/moles of converted NO) for the $1 \mathrm{~cm}^{3}$ of NO pulses over autoreduced and pre-treated Cu-ZSM-5-83 and Cu-ZSM-5-127 at $673 \mathrm{~K}$; IR band intensities during the pulse reaction studies over site-poisoned catalysts

\begin{tabular}{|c|c|c|c|c|c|c|c|c|}
\hline \multicolumn{5}{|c|}{$\mathrm{Cu}-Z S M-5-83$} & \multicolumn{4}{|c|}{$\mathrm{Cu}-Z S M-5-127$} \\
\hline & $\begin{array}{c}\text { Auto- } \\
\text { reduction }\end{array}$ & Water & Silane & Sulfur Dioxide & Auto-reduction & Water & Silane & Sulfur Dioxide \\
\hline \multicolumn{9}{|l|}{ Conversion (\%) } \\
\hline NO & 7.2 & 3.1 & 2.4 & 0.0 & 20.4 & 3.9 & 5.2 & 0.0 \\
\hline \multicolumn{9}{|l|}{ Yield (\%) } \\
\hline $\mathrm{N}_{2}$ & 0.0 & 0.0 & 0.0 & 0.0 & 29.7 & 26.2 & 25.0 & 0.0 \\
\hline $\mathrm{O}_{2}$ & 3.4 & 2.2 & 0.0 & 0.0 & 9.5 & 2.3 & 0.0 & 0.0 \\
\hline $\mathrm{N}_{2} \mathrm{O}$ & 35.6 & 34.8 & 33.3 & 0.0 & 0.0 & 0.0 & 0.0 & 0.0 \\
\hline $\mathrm{NO}_{2}$ & 40.5 & 30.3 & 33.3 & 0.0 & 28.8 & 47.6 & 50.0 & 0.0 \\
\hline \multicolumn{9}{|l|}{$\underline{\text { IR bands }}$} \\
\hline $\mathrm{NO}^{+}$ & Strong & Weak & Weak & Strong & Weak & Weak & Absent & Weak \\
\hline $\mathrm{Cu}^{+}(\mathrm{NO})$ & Strong & Weak & Weak & Weak & Strong & Weak & Weak & Weak \\
\hline $\mathrm{Cu}^{2+} \mathrm{O}^{-}(\mathrm{NO})$ & Absent & Strong & Absent & Absent & Weak & Absent & Weak & Weak \\
\hline $\mathrm{Cu}^{2+}(\mathrm{NO})$ & Strong & Absent & Strong & Strong & Absent & Weak & Absent & Absent \\
\hline $\mathrm{Cu}^{2+}\left(\mathrm{NO}_{3}\right)_{\text {bridged }}$ & Strong & Absent & Absent & Absent & Strong & Absent & Absent & Absent \\
\hline
\end{tabular}




\section{NO pulse studies}

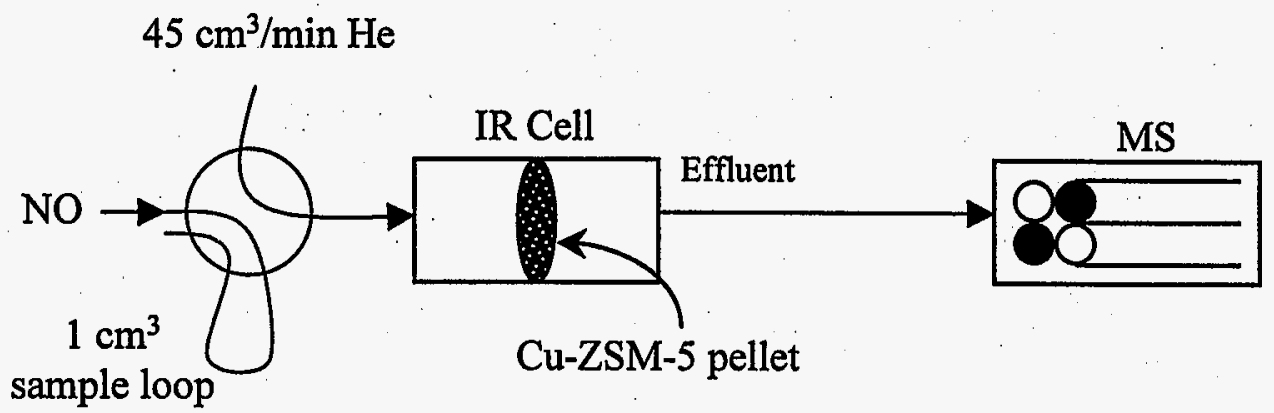

\section{CO pulse studies}

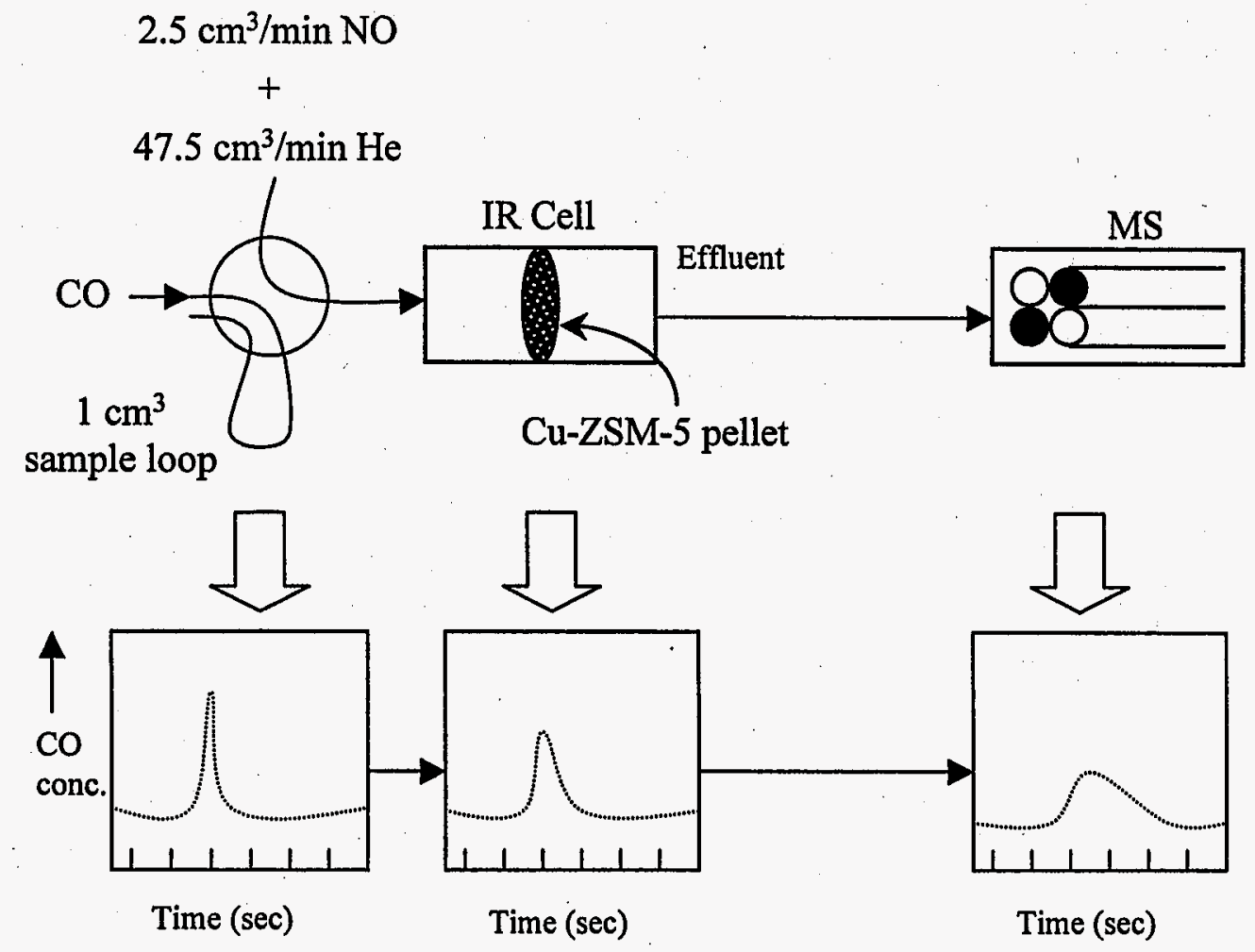

Figure 1 

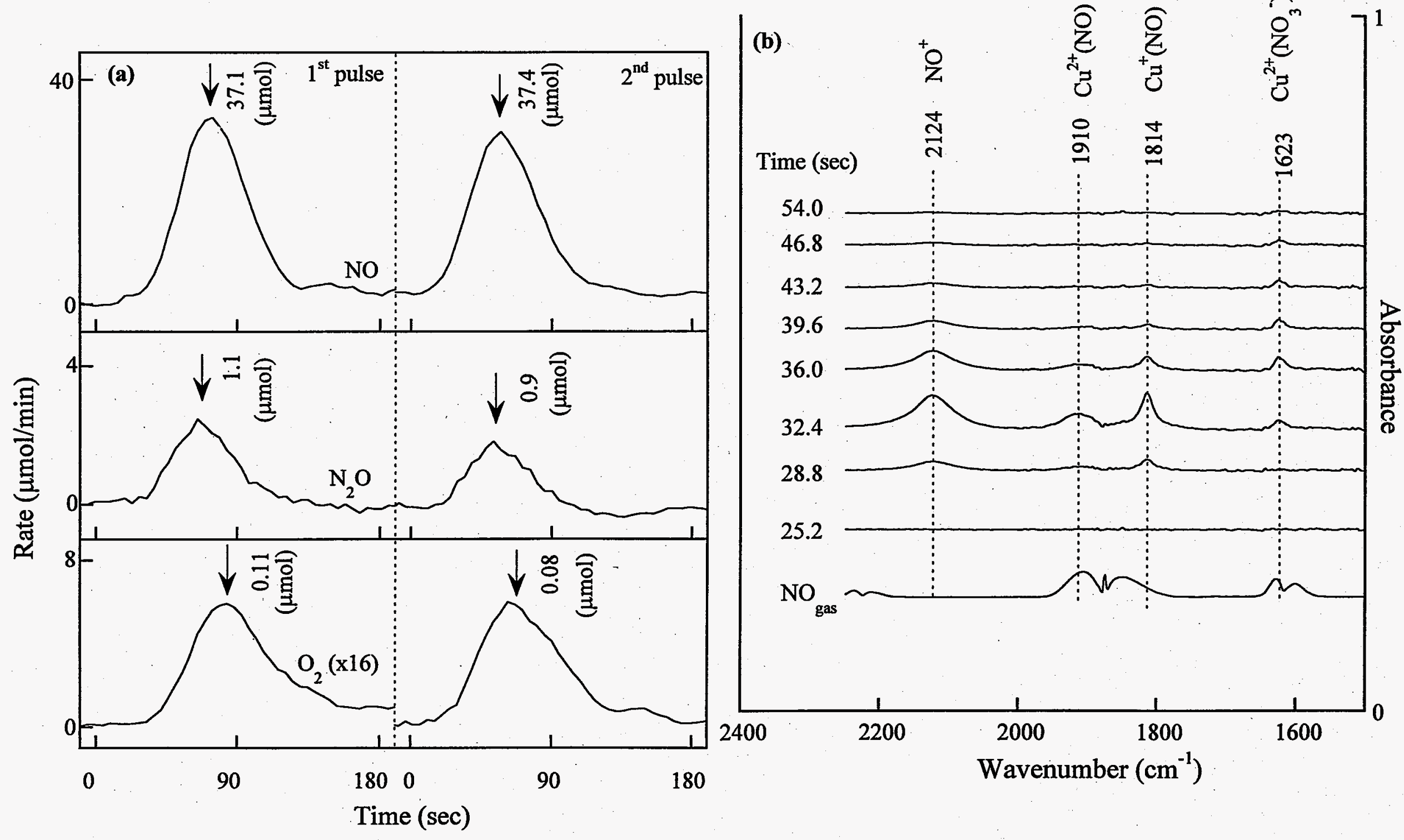


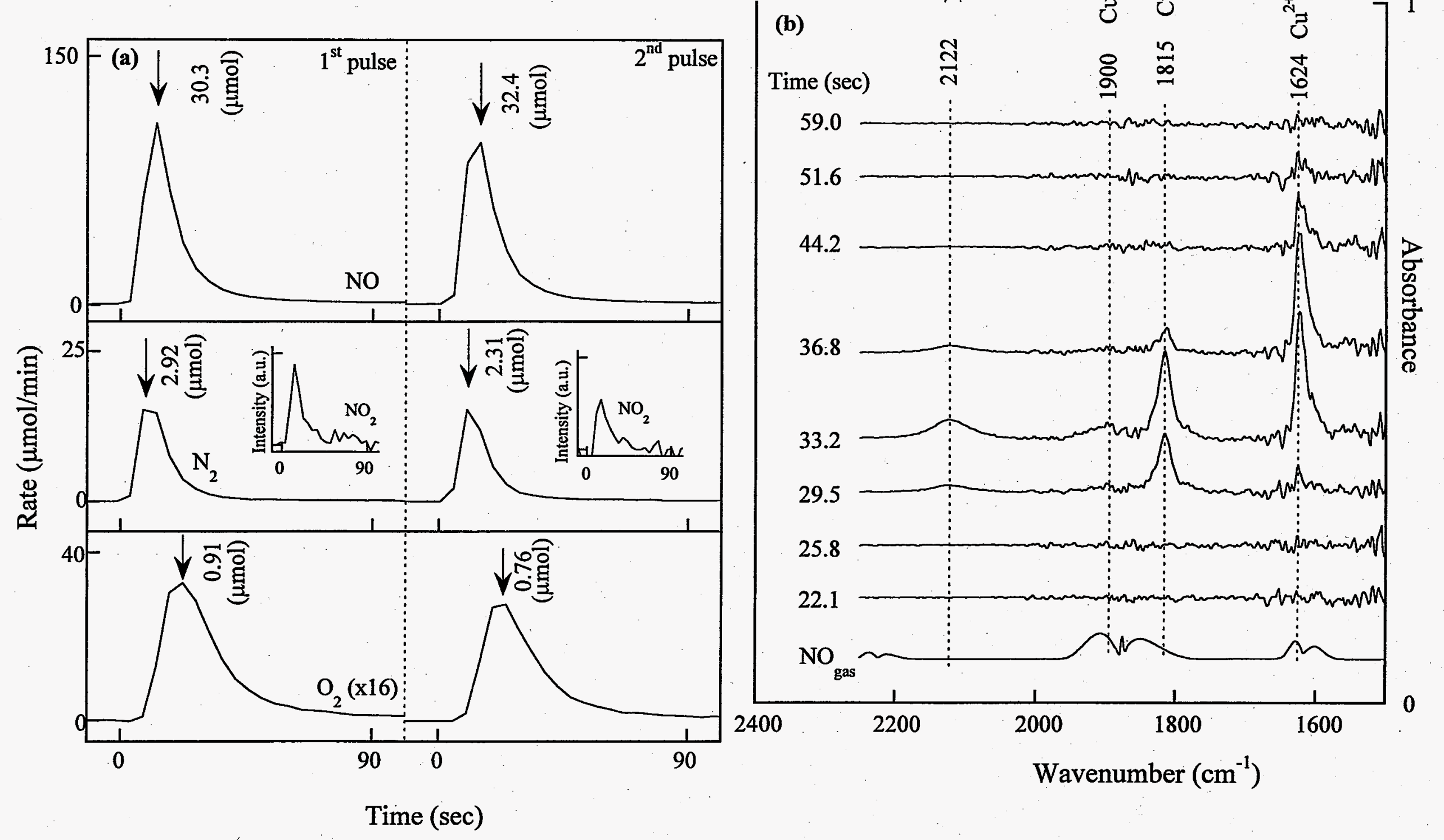



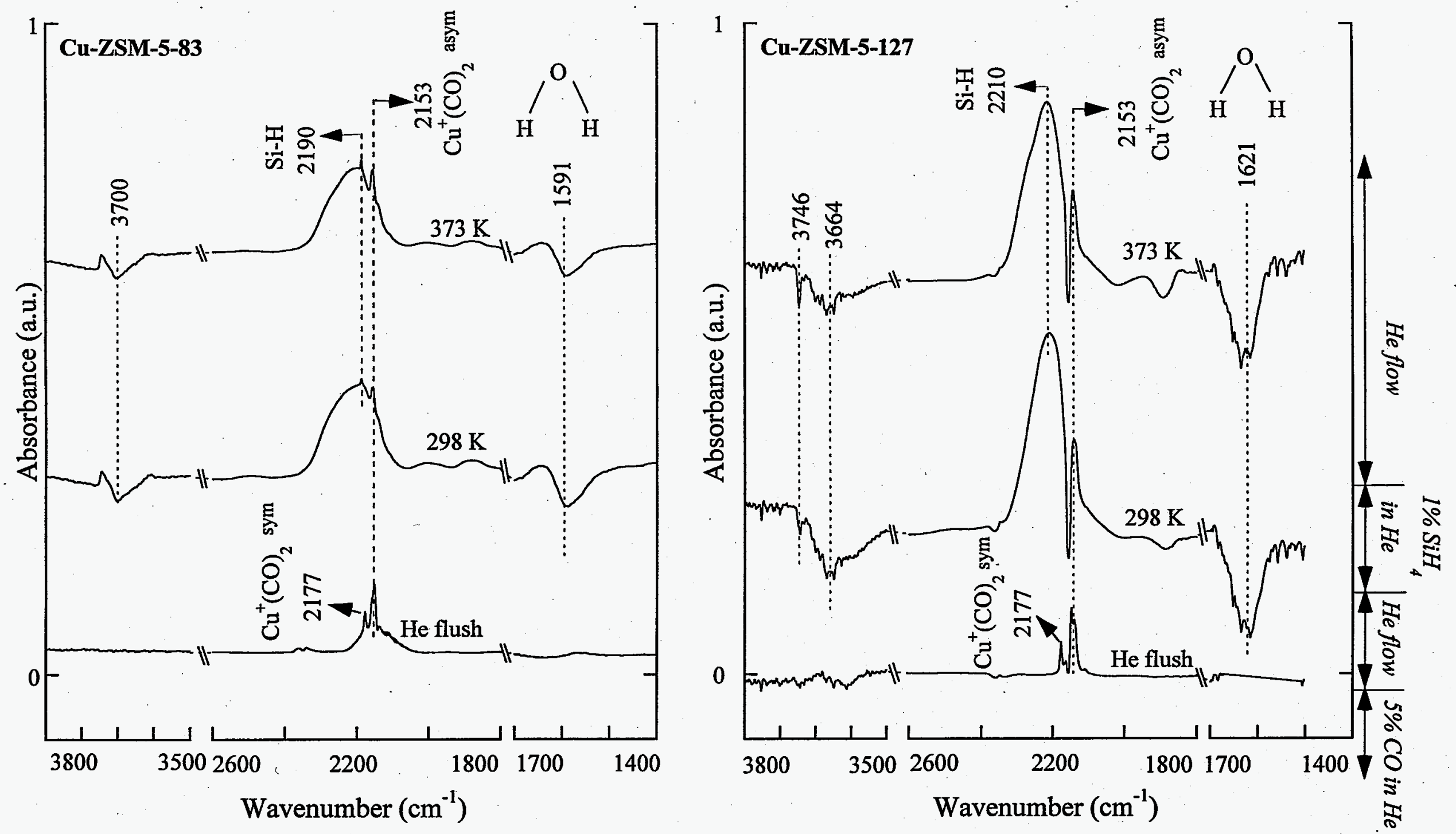

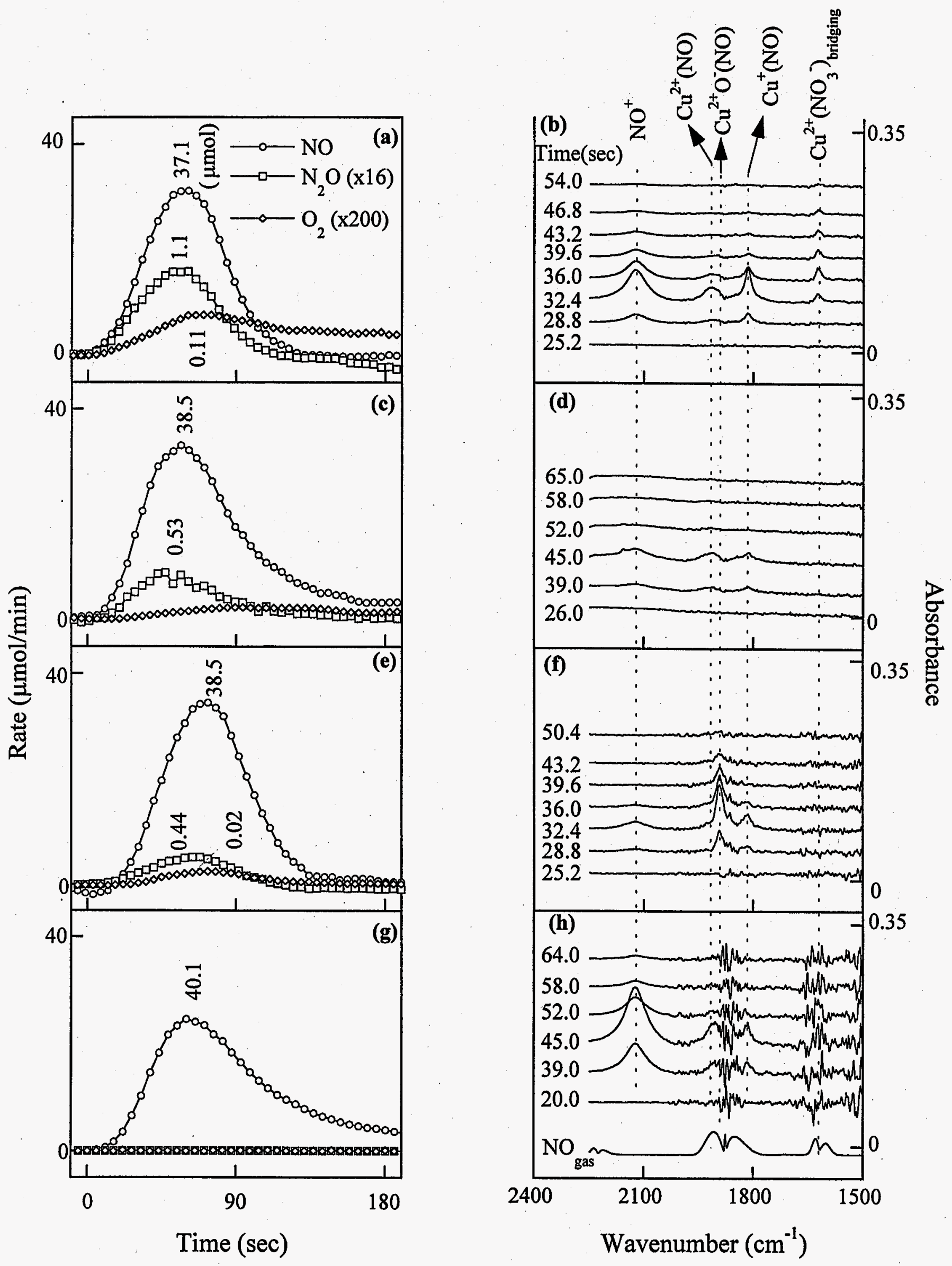

Figure 5 

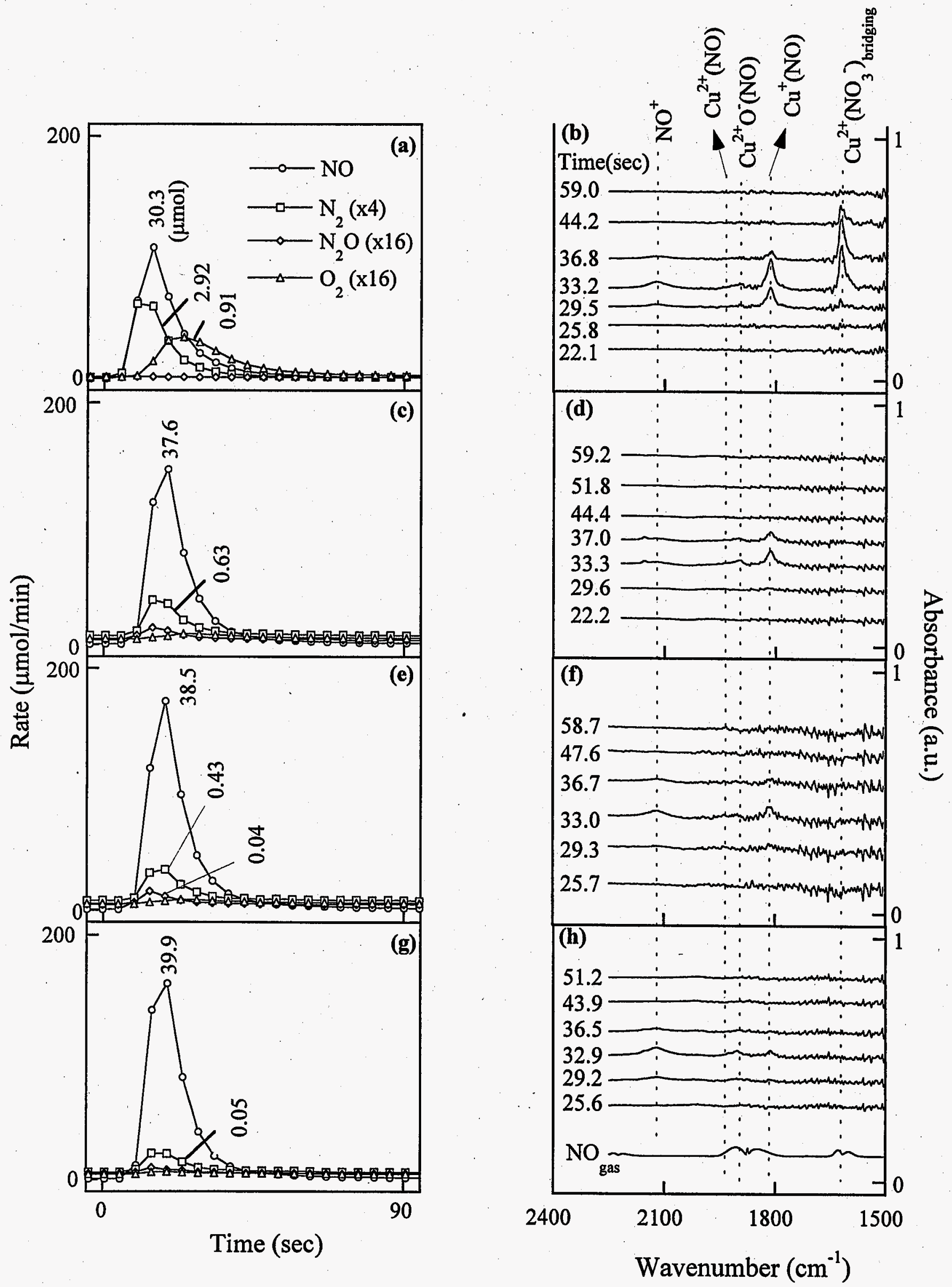

Figure 6 


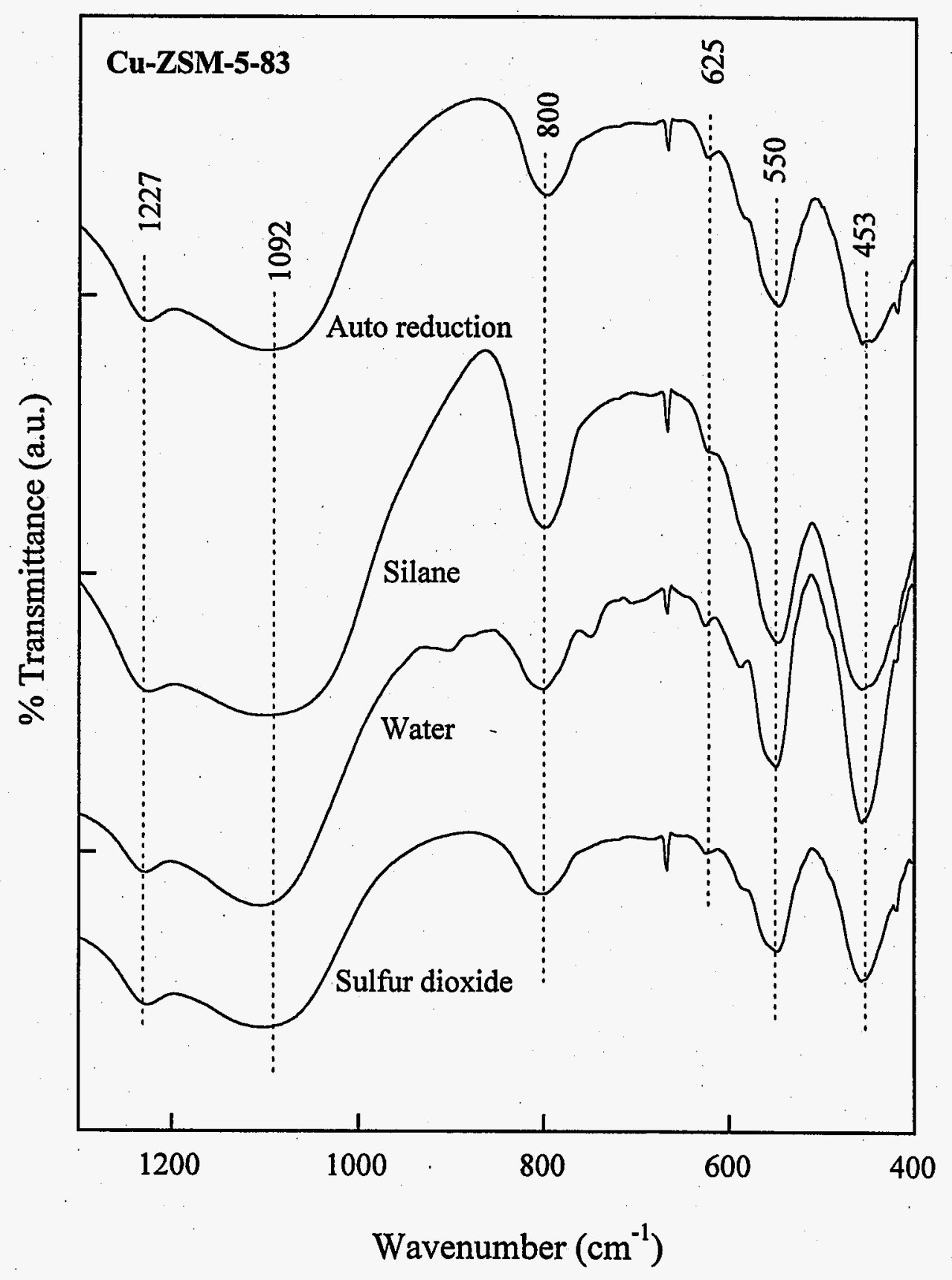




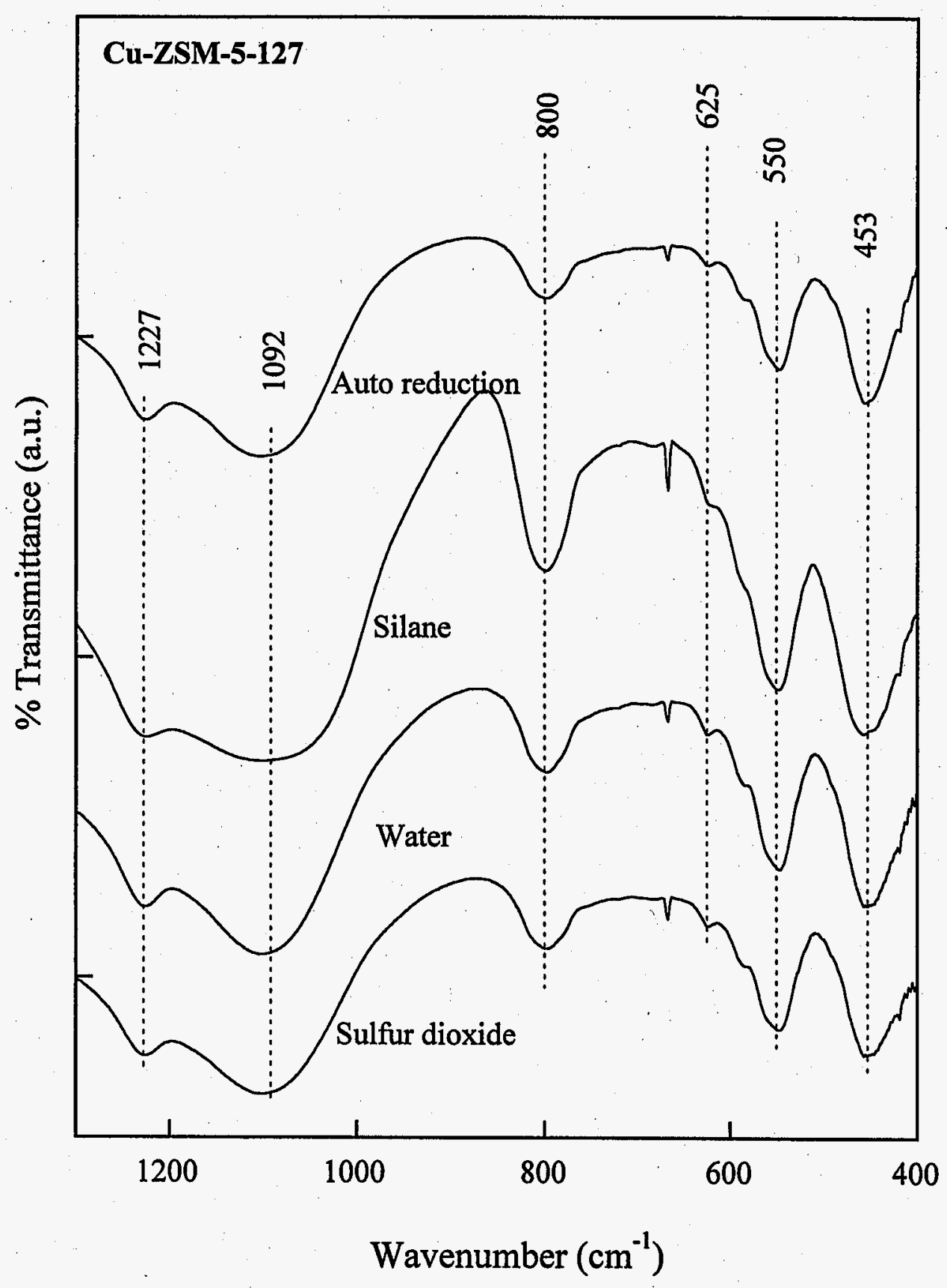

Figure 8 


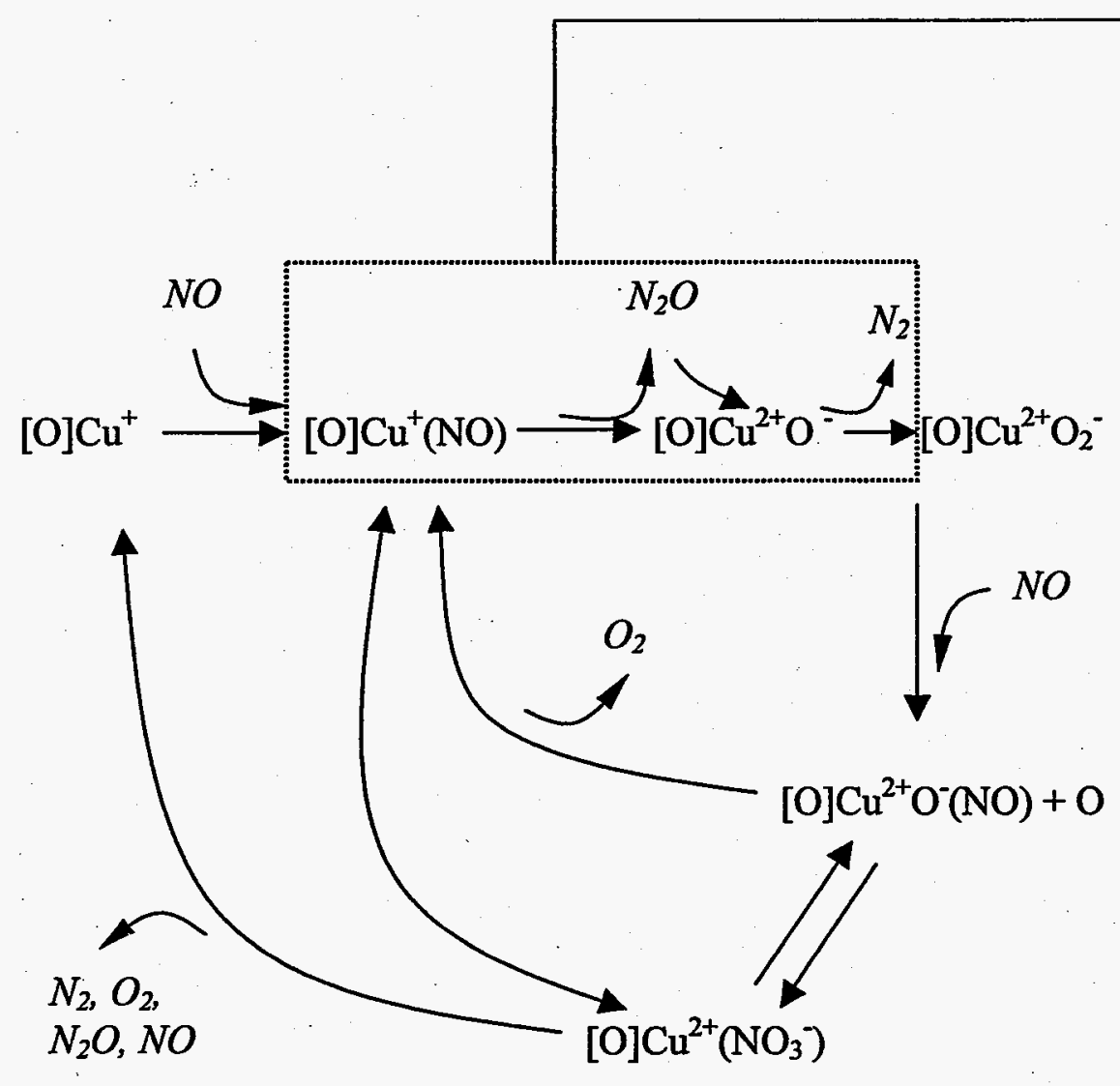

Reported pathways for $\mathrm{N}_{2} \mathrm{O}$ and $\mathrm{N}_{2}$ formation

$\underline{\text { Path I (14) }}$

1. $\mathrm{Cu}^{+}+\mathrm{NO} \rightarrow \mathrm{Cu}^{(1+\delta)}-\mathrm{NO}^{\delta-}$

2. $2 \mathrm{Cu}^{(1+\delta)}-\mathrm{NO}^{\delta-} \rightarrow \mathrm{Cu}^{2+}-\mathrm{O}-\mathrm{Cu}^{2+}+\mathrm{N}_{2} \mathrm{O}\left(\mathrm{N}_{2}\right)$

Path II (20)

1. $\mathrm{Cu}^{2+}+\mathrm{NO} \rightarrow \mathrm{Cu}^{+}-(\mathrm{NO})^{+}$

2. $2 \mathrm{Cu}^{+}-(\mathrm{NO})^{+} \rightarrow(\mathrm{Cu}-\mathrm{O}-\mathrm{Cu})^{2+}+\mathrm{N}_{2} \mathrm{O}$

$\underline{\text { Path III (39) }}$

1. $\mathrm{ZCu}+\mathrm{NO} \rightarrow \mathrm{ZCu}-\mathrm{NO}$

2. $\mathrm{ZCu}-\mathrm{NO}+\mathrm{NO} \rightarrow \mathrm{ZCuO}+\mathrm{N}_{2} \mathrm{O}$

3. $\mathrm{ZCuO}+\mathrm{N}_{2} \mathrm{O} \rightarrow \mathrm{ZCuO}_{2}+\mathrm{N}_{2}$ 


\section{Promotion of Oxygen Desorption To Enhance Direct NO Decomposition over $\mathrm{Tb}-\mathrm{Pt} / \mathrm{Al}_{2} \mathrm{O}_{3}$ Catalyst}

Steven S. C. Chuang and Cher-Dip Tan

Department of Chemical Engineering, University of Akron, Akron, Ohio 44325-3906

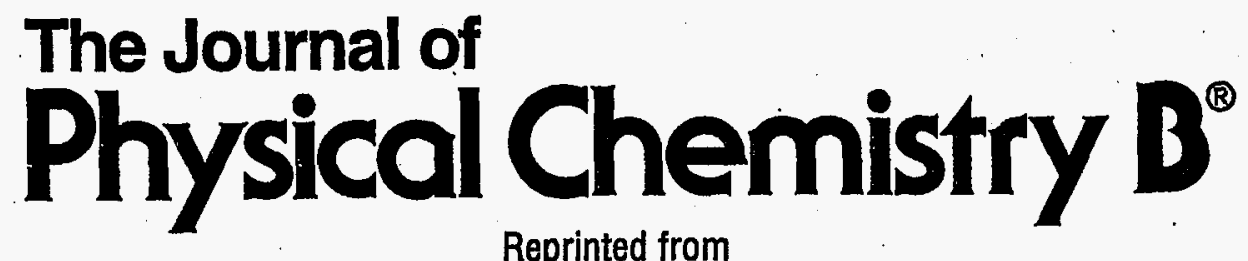

Reprinted from

Volume 101, Number 15, Pages 3000-3004 


\title{
Promotion of Oxygen Desorption To Enhance Direct NO Decomposition over $\mathrm{Tb}-\mathrm{Pt} / \mathrm{Al}_{2} \mathrm{O}_{3}$ Catalyst
}

\author{
Steven S. C. Chuang* and Cher-Dip Tan \\ Department of Chemical Engineering, University of Akron, Akron, Ohio 44325-3906
}

Received: December 19, $1996^{\circ}$

\begin{abstract}
Promotion of oxygen desorption at low temperatures holds the key to the development of an effective NO decomposition catalyst. Addition of $\mathrm{Tb}$ oxide to $\mathrm{Pt}_{\mathrm{Al}} \mathrm{O}_{3}$ allows oxygen from dissociated NO to desorb at $593 \mathrm{~K}$, which is significantly lower than the reported oxygen desorption temperatures for Pt catalysts. Combined temperature-programmed desorption/reaction with in situ infrared study reveals that desorbed oxygen is produced from decomposition of chelating bidentate nitrato, which may result from the reaction of adsorbed oxygen on $\mathrm{Pt}$ and adsorbed $\mathrm{NO}$ on $\mathrm{Tb}$ oxide. The Tb-promoted $\mathrm{Pt}_{\mathrm{Al}} \mathrm{O}_{3}$ catalyst which possesses oxygen desorption capability at low temperatures shows the activity for decomposition of $\mathrm{NO}$ to $\mathrm{N}_{2}, \mathrm{~N}_{2} \mathrm{O}, \mathrm{NO}_{2}$, and $\mathrm{O}_{2}$ under pulse and steady-state reaction conditions at $773-923 \mathrm{~K}$.
\end{abstract}

\section{Introduction}

The direct decomposition of nitric oxide to harmless nitrogen and oxygen is an attractive approach for the control of $\mathrm{NO}$ emission because of its chemical simplicity. The direct NO decomposition, $2 \mathrm{NO} \rightarrow \mathrm{N}_{2}+\mathrm{O}_{2}$, is thermodynamically favorable at temperatures below $2000 \mathrm{~K}$. Development of an effective catalyst for the direct NO decomposition will eliminate the use of reducing reactants, such as $\mathrm{H}_{2}, \mathrm{CO}, \mathrm{NH}_{3}$, and hydrocarbons, significantly simplifying the NO removal process and dramatically decreasing the cost of NO control for the exhausts of various combustion processes. Extensive catalyst searching and screening studies for the past two decades have led to the discovery of Cu-ZSM-5 catalysts, which exhibit the bighest activity for the direct NO decomposition among various catalysts tested. ${ }^{2}$ However, the narrow temperature window of operation for $\mathrm{Cu}-\mathrm{ZSM}-5$, its susceptibility to $\mathrm{SO}_{2}$ poisoning, and rapid deactivation by $\mathrm{H}_{2} \mathrm{O}$ severely limit its potential for practical use. ${ }^{2,3}$ Development of a durable catalyst for the direct NO decomposition remains a major challenge in the area of environmental catalysis. ${ }^{4-6}$

Knowledge of elementary processes governing the NO decomposition may help guide the development of practical catalysts. Examination of the proposed elementary steps for NO decomposition has revealed that the low NO decomposition activity of a catalyst is due to its inability to desorb oxygen produced from NO dissociation.' Oxygen from dissociated NO is strongly bonded to the catalyst surface, poisoning NO dissociation sites and preventing further NO dissociation. The conventional approach to remove adsorbed oxygen from the catalyst surface includes (i) the utilization of high temperature to desorb adsorbed oxygen and (ii) the employment of gaseous reductant to react with adsorbed oxygen. The former is a hightemperature process that requires use of extensive energy; the latter involves a reductant that eliminates the unique advantage of the direct NO decomposition.

A novel approach to improve the activity of a NO decomposition catalyst is to enhance either the desorption of adsorbed oxygen or spillover of adsorbed oxygen from the NO dissociation site..$^{7,8}$ Promotion of oxygen desorption should create free sites needed for further NO dissociation. A literature search in

* To whom correspondence should be addressed.

- Abstract published in Advance ACS Abstracts, March 15, 1997. the area of oxygen spillover revealed that nonstoichiometric rare earth oxides such as $\mathrm{Tb}$ and $\mathrm{Pr}$ oxides may uptake and release adsorbed oxygen and exhibit self-decomposition activity, releasing oxygen at 773 and $613 \mathrm{~K}$, respectively. ${ }^{9-11}$ We have, therefore, postulated that the nonstoichiometric rare earth oxides may act as a promoter either to facilitate the spillover of adsorbed oxygen or to promote the desorption of adsorbed oxygen from the NO dissociation site, resulting in enhancing the NO decomposition activity. This paper reports the result of an investigation of the effect of $\mathrm{Tb}$ oxide on the nature (i.e., reactivity and structure) of adsorbates for NO dissociation and for oxygen desorption by a combined in situ infrared spectroscopy and temperature-programmed desorption/reaction technique as well as steady-state reaction study.

\section{Experimental Section}

The catalyst used for this study is a 1 wt \% Tb-Pt/Al $\mathrm{Al}_{2} \mathrm{O}_{3}$ (Tb:Pt $=10: 1$, which was prepared by coimpregnating a solution of $\mathrm{Tb}\left(\mathrm{NO}_{3}\right)_{3} \cdot 5 \mathrm{H}_{2} \mathrm{O}$ (Alfa Products) and $\mathrm{H}_{2} \mathrm{PtCl}_{6} \cdot 6 \mathrm{H}_{2} \mathrm{O}$ (Alfa Products) onto a large surface area $\gamma-\mathrm{Al}_{2} \mathrm{O}_{3}$ support (Alfa Products, $100 \mathrm{~m}^{2} / \mathrm{g}$ of surface area, $0.01-0.02 \mu \mathrm{m}$ pore size). The low loading of $\mathrm{Pt}$ is used to emulate the loading of precious metal in the automotive catalysts. The ratio of the volume of solution to the weight of alumina support used in the impregnation step was $1 \mathrm{~cm}^{3}$ to $2 \mathrm{~g}$. The catalyst was dried overnight in air at $303 \mathrm{~K}$ after impregnation and then reduced in flowing hydrogen at $673 \mathrm{~K}$ for $8 \mathrm{~h}$. The $\mathrm{Tb}-\mathrm{Pt}_{\mathrm{Al}} \mathrm{O}_{3}$ catalyst prepared was characterized by $\mathrm{X}$-ray diffraction (XRD). The XRD pattern reveals the presence of $\mathrm{Tb}_{2} \mathrm{O}_{3}$ crystallite and a possible $\mathrm{Tb}_{3} \mathrm{Al}_{2} \mathrm{Al}_{3} \mathrm{O}_{12}$ species on the $\mathrm{Al}_{2} \mathrm{O}_{3}$ surface. The absence of the XRD pattern of $\mathrm{Pt}$ crystallite indicates that $\mathrm{Pt}$ is highly dispersed on the catalyst with the crystallite size smaller than $30 \AA$.

The details of in situ infrared (IR) reactor cell, experimental apparatus, and procedures bave been reported elsewhere. ${ }^{12}$ The catalyst powder which has been exposed to air was pressed into three self-supporting disks ( $40 \mathrm{mg}$ each); one of the disks was placed in the IR cell, and the other two disks were broken down into flakes and placed at the exit line in the immediate vicinity of the infrared beam path. The additional catalyst disks were used to increase the amount of desorbing species and conversion to obtain a strong signal in the mass spectrometer.

Following the pretreatment of the catalyst in the IR cell with helium flow at $773 \mathrm{~K}$ for $1 \mathrm{~h}$, the catalyst was exposed to 10 

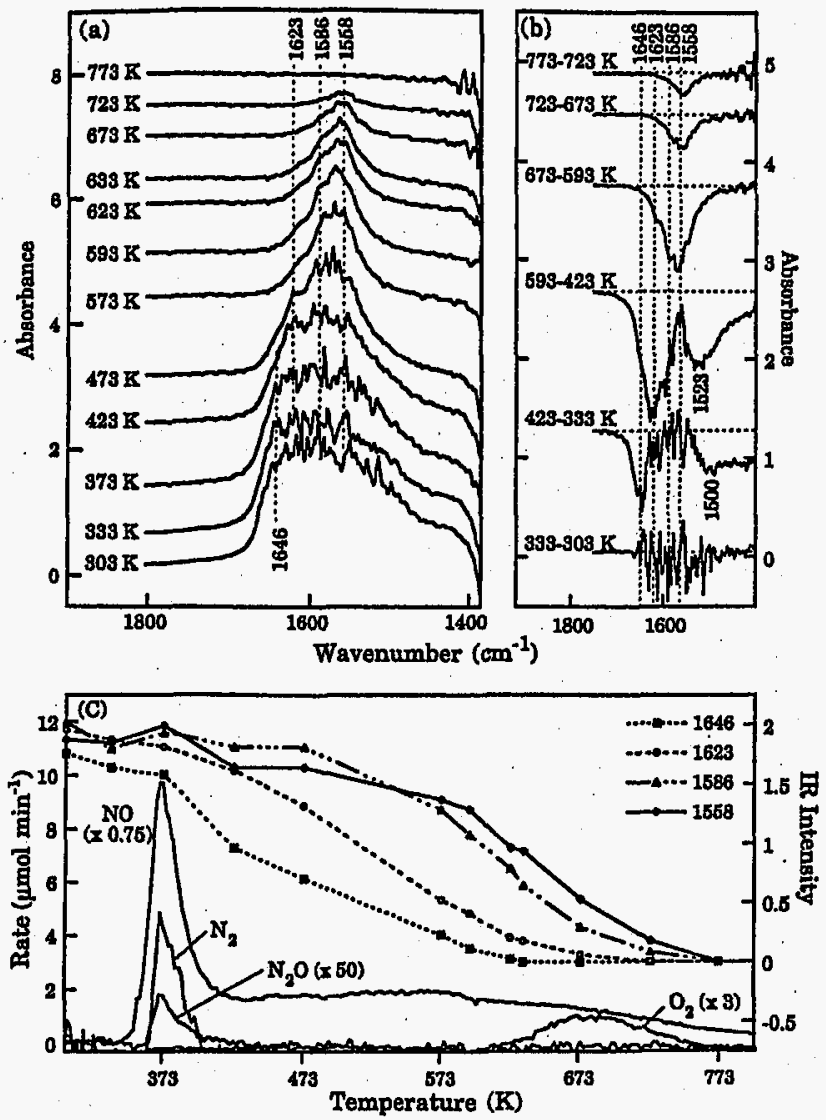

Figure 1. (a) Infrared spectra during NO TPD/R on 1 wt $\% \mathrm{~Tb}-\mathrm{Pt}$ $\mathrm{Al}_{2} \mathrm{O}_{3}$ at a heating rate of $20 \mathrm{~K} \mathrm{~min}^{-1}$ from 303 to $773 \mathrm{~K}$. (b) Spectral differences; the 423-333 $\mathrm{K}$ spectrum is a result of the subtraction of IR absorbance at $333 \mathrm{~K}$ from that at $423 \mathrm{~K}$. (c) Rate of elution for gaseous species from the $\mathbb{R}$ cell and variation of $\mathbb{R}$ intensities with temperature.

$\mathrm{cm}^{3} \mathrm{~min}^{-1}$ of NO for $10 \mathrm{~min}$ at $303 \mathrm{~K}$. Temperatureprogrammed desorption/reaction (TPD/R) studies were carried out from 303 to $773 \mathrm{~K}$ at a heating rate of $20 \mathrm{~K} \mathrm{~min}^{-1}$ with a $40 \mathrm{~cm}^{3} \mathrm{~min}^{-1}$ of He flow. TPD/R is referred to both desorption and reaction of adsorbed NO taking place simultaneously as adsorbates are subject to temperature-programmed heating. Changes in concentration of adsorbates and products during TPD/R and pulse reaction studies were determined simultaneously by infrared spectroscopy and mass spectrometer, respectively. Catalyst activity and selectivity were tested by two modes: pulsing either $500 \mu \mathrm{L}$ or $1 \mathrm{~cm}^{3}$ of NO into $40 \mathrm{~cm}^{3}$ $\min ^{-1}$ He flow over catalyst in an in situ $\mathbb{R}$ cell at 673 and $723 \mathrm{~K}$ and steady-state flow reaction study over the catalyst in a stainless steel tubular reactor from 723 and $923 \mathrm{~K}$. Concentration of product effluent from stainless steel tubular flow reactor is monitored by mass spectrometry, GC/MS (gas chromatography/mass spectrometry), and infrared spectroscopy with a gaseous IR cell.

\section{Results and Discussion}

Figure 1a shows the $\mathbb{R}$ spectra of adsorbates during the TPD/R in $40 \mathrm{~cm}^{3} \mathrm{~min}^{-1}$ He flow following the NO adsorption at $303 \mathrm{~K}$. IR bands below $1400 \mathrm{~cm}^{-1}$ were not observed due to the large noise-to-signal ratio and the cutoff of the $\mathbb{R}$ transmission below $1250 \mathrm{~cm}^{-1}$ by $\mathrm{Al}_{2} \mathrm{O}_{3}$ support. The initial spectrum, a result of exposure of the catalyst to the NO flow at $303 \mathrm{~K}$, shows the $\mathrm{Pt}-\mathrm{NO}^{-}$band at $1646 \mathrm{~cm}^{-1}$ and nitrate bands in the $1630-1400 \mathrm{~cm}^{-1}$ region. The assignment of infrared spectra of adsorbed nitrate species has not been well established. Comparison of the infrared spectra of adsorbed nitrate $\left(\mathrm{NO}_{3}{ }^{-}\right)$ with those of nitrato complexes suggests that the $1623 \mathrm{~cm}^{-1}$ band may be assigned to the bridged bidentate,<smiles></smiles>

the $1558 \mathrm{~cm}^{-1}$ band and the shoulder band at $1550 \mathrm{~cm}^{-1}$ to the chelating bidentate,<smiles>N1OOO1</smiles>

where $M$ is a metal atom. ${ }^{13}$.

Temperature-programmed desorption/reaction (TPD/R) caused variation in both infrared spectra of adsorbed NO species and eluted rate of gaseous species. In order to clearly discern the change in the concentration of various adsorbates due to TPD/ $R$, spectral differences were taken in Figure $1 b$ and compared with the eluted rate of gaseous products in Figure $1 \mathrm{c}$ to reveal the contribution of the specific adsorbates to the formation of gaseous products. The elution rate of each species was obtained by multiplying its MS intensity with a calibration factor that is determined by injecting a known amount of the species into the MS and measuring the area under the response curve.

Figure 1a shows that the intensities of $\mathrm{Pt}-\mathrm{NO}^{-}$at $1646 \mathrm{~cm}^{-1}$, and bidentate nitrates in the $1545-1500 \mathrm{~cm}^{-1}$ region began to decrease at temperatures above $333 \mathrm{~K}$. The decrease in the intensity of these bands is highlighted in Figure $1 \mathrm{~b}$ by the negative difference spectrum for $423-323 \mathrm{~K}$ where NO, $\mathrm{N}_{2}$, and $\mathrm{N}_{2} \mathrm{O}$ evolved, giving the peak temperature at $373 \mathrm{~K}$ in Figure 1c. The amount of $\mathrm{NO}, \mathrm{N}_{2}$, and $\mathrm{N}_{2} \mathrm{O}$ desorbed under the $373 \mathrm{~K}$ peak corresponds to $30.6,20.7$, and $1.0 \mu \mathrm{mol}$, respectively. Formation of $\mathrm{N}_{2}$ and $\mathrm{N}_{2} \mathrm{O}$ suggests the occurrence of

$$
\begin{aligned}
& 2 \mathrm{NO}_{\mathrm{ad}} \rightarrow \mathrm{N}_{2}+2 \mathrm{O}_{\mathrm{ad}} \\
& 2 \mathrm{NO}_{\mathrm{ad}} \rightarrow \mathrm{N}_{2} \mathrm{O}+\mathrm{O}_{\mathrm{ad}}
\end{aligned}
$$

Stoichiometry of reactions 1 and 2 suggests that the formation of these $\mathrm{N}_{2}$ and $\mathrm{N}_{2} \mathrm{O}$ at $373 \mathrm{~K}$ peak should leave $42.4 \mu \mathrm{mol}$ of adsorbed oxygen on the catalyst surface. Adsorbed oxygen on the surface of metal and metal oxide cannot be observed from this study because its vibrational frequency in $200-450 \mathrm{~cm}^{-1}$ region ${ }^{14}$ is below the $\mathbb{R}$ transmission range of $\mathrm{CaF}_{2}$ and $\mathrm{Al}_{2} \mathrm{O}_{3}$ support used in this study. Adsorbed oxygen did not desorb as gaseous oxygen molecule until temperature reaching $593 \mathrm{~K}$. In the temperature range between 423 and $593 \mathrm{~K}$, the main TPDIR feature is the constant NO elution rate (Figure 1c) with a substantial decrease in the bidentate bands at 1623 and 1523 $\mathrm{cm}^{-1}$. A marked decrease in IR intensity of these bidentate bands has also been observed with NO elution in the same temperature range during TPD/R of adsorbed $\mathrm{NO}$ on $\mathrm{Al}_{2} \mathrm{O}_{3}$. The similarity in the negative difference spectra for these two catalysts suggests a part of the bidentate nitrates at 1623 and $1523 \mathrm{~cm}^{-1}$ is a result of direct adsorption of $\mathrm{NO}$ on the $\mathrm{Al}_{2} \mathrm{O}_{3}$ surface.

At temperatures above $593 \mathrm{~K}$, adsorbed oxygen began to desorb and exhibited the peak at $683 \mathrm{~K}$ while difference $\mathrm{IR}$ spectra showed a significant decrease in the intensity of the 1558 $\mathrm{cm}^{-1}$ band. The amount of desorbed oxygen $(4.7 \mu \mathrm{mol})$ is less than that of oxygen produced during the formation of $\mathrm{N}_{2}$ and $\mathrm{N}_{2} \mathrm{O}$ at $373 \mathrm{~K}$.

Since a practical catalyst for NO decomposition must work in an oxidizing environment, the catalyst was further treated with air at $773 \mathrm{~K}$ for $1 \mathrm{~h}$ and then cooled to $303 \mathrm{~K}$ in helium for NO adsorption and TPD/R studies to determine the activity 
of the oxidized $\mathrm{Tb}-\mathrm{Pt} / \mathrm{Al}_{2} \mathrm{O}_{3}$ for the NO decomposition. Figure 2a shows the IR spectra during the NO TPD/R on the oxidized $\mathrm{Tb}-\mathrm{Pt} / \mathrm{Al}_{2} \mathrm{O}_{3}$. Comparison of results in Figures 1 and 2 reveals the effect of air treatment at $773 \mathrm{~K}$ on the reactivity of adsorbates and the catalyst surface state. The air treatment led to the following changes in IR spectra and TPD/R product profiles: (i) Air treatment decreased the intensity of $\mathrm{Pt}^{-\mathrm{NO}^{-}}$band at $1646 \mathrm{~cm}^{-1}$ by $50 \%$. (ii) Air treatment decreased the amount of $\mathrm{N}_{2}$ formation and completely suppressed $\mathrm{N}_{2} \mathrm{O}$ formation. (iii) Air treatment increased the amount of $\mathrm{O}_{2}$ and NO desorbed at $683 \mathrm{~K}$. These changes brought about by the air treatment suggest that (1) formation of $\mathrm{N}_{2} \mathrm{O}$ requires a large fraction of reduced $\mathrm{Pt}$ surface and (2) $\mathrm{Pt}-\mathrm{NO}^{-}$may be the precursor for the NO dissociation. One common feature between the reduced and air-treated catalysts is that oxygen desorption at $683 \mathrm{~K}$ is closely related to a significant decrease in $I R$ intensity of chelating bidentate at $1558 \mathrm{~cm}^{-1}$. A subtle difference in the formation of chelating bidentate on these two catalysts. was noted. The majority of chelating bidentate was formed during $\mathrm{NO}$ adsorption on $\mathrm{Tb}-\mathrm{Pt} / \mathrm{Al}_{2} \mathrm{O}_{3}$ at room temperature while some of chelating bidentate was generated during TPD/R on air-treated $\mathrm{Tb}-\mathrm{Pt}_{\mathrm{Al}} \mathrm{O}_{3}$ at $333-473 \mathrm{~K}$.

The above observations led to postulation of the following pathway for the decomposition of $\mathrm{NO}$ to $\mathrm{N}_{2}, \mathrm{~N}_{2} \mathrm{O}$, and $\mathrm{O}_{2}$ on the $\mathrm{Tb}-\mathrm{Pt} / \mathrm{Al}_{2} \mathrm{O}_{3}$ :

step 1. $\quad \mathrm{NO}+\mathrm{Pt} \rightarrow \mathrm{Pt}-\mathrm{NO}^{-}$

step 2. $\mathrm{NO}+\mathrm{TbO}_{x} \rightarrow \mathrm{TbO}_{x}-\mathrm{NO}$

step 3. $\mathrm{Pt}-\mathrm{NO}^{-}+\mathrm{Pt} \rightarrow \mathrm{Pt}-\mathrm{N}+\mathrm{Pt}-\mathrm{O}$

step 4. $\quad 2 \mathrm{Pt}-\mathrm{N} \rightarrow \mathrm{N}_{2}+2 \mathrm{Pt}$

step 5. $\quad \mathrm{Pt}-\mathrm{N}+\mathrm{Pt}-\mathrm{NO} \rightarrow \mathrm{N}_{2} \mathrm{O}+2 \mathrm{Pt}$

step 6. $\quad 2 \mathrm{Pt}-\mathrm{O}+\mathrm{TbO}_{x}-\mathrm{NO} \rightarrow$ $2 \mathrm{Pt}+\mathrm{TbO}_{x}-\mathrm{NO}_{3}$ (chelating bidentate)

step 7. $\quad \mathrm{TbO}_{x}-\mathrm{NO}_{3} \rightarrow \mathrm{TbO}_{x}+\mathrm{NO}+\mathrm{O}_{2}$

It should be noted that the whole $\mathrm{Pt}-\mathrm{NO}^{-}$entity should be considered neutral. The proposed pathway for the formation of gaseous oxygen molecules from TPD/R involves (i) the dissociation of adsorbed NO on the $\mathrm{Pt}$ surface, step 3 , at temperatures below $473 \mathrm{~K}$, (ii) the reaction of adsorbed oxygen with adsorbed NO on the Tb oxide surface to form a chelating bidentate species, step 6 , and (iii) the decomposition of the chelating bidentate to produce $\mathrm{NO}$ and $\mathrm{O}_{2}$, step 7 , at temperatures above $593 \mathrm{~K}$.

To compare the oxygen desorption profile of $\mathrm{Pt} / \mathrm{Al}_{2} \mathrm{O}_{3}$ and $\mathrm{Tb}-\mathrm{Pt} / \mathrm{Al}_{2} \mathrm{O}_{3}, \mathrm{TPD} / \mathrm{R}$ of adsorbed $\mathrm{NO}$ was also carried out on $\mathrm{Pt} / \mathrm{Al}_{2} \mathrm{O}_{3} . \mathrm{O}_{2}$ was not found in the temperature range 303$873 \mathrm{~K}$ during TPD/R of adsorbed $\mathrm{NO}$ on $\mathrm{Pt} / \mathrm{Al}_{2} \mathrm{O}_{3}$. Due to the operating temperature limit of the IR cell, TPD/R was not able to conduct at temperatures above $873 \mathrm{~K}$. Oxygen from dissociated NO has been found to desorb at $1000 \mathrm{~K}$ for $\mathrm{Pt}(111)$ surface which does not exhibit NO decomposition activity in the $673-973 \mathrm{~K}^{15}$ Lowering the oxygen desorption temperature on the $\mathrm{Tb}-\mathrm{Pt}_{\mathrm{Al}} \mathrm{A}_{2} \mathrm{O}_{3}$ should facilitate desorption of adsorbed oxygen and regenerate sites needed for NO dissociation to complete the catalytic site for NO decomposition.

Since the oxygen desorption peak temperature was observed near $673 \mathrm{~K}$ on $\mathrm{Tb}-\mathrm{Pt}_{\mathrm{Al}} \mathrm{Al}_{2}$, the activity of the catalyst was first tested at $673 \mathrm{~K}$ by pulsing $500 \mu \mathrm{L}$ of NO into helium carrier gas over the catalyst. Pulse reaction studies allow accurate
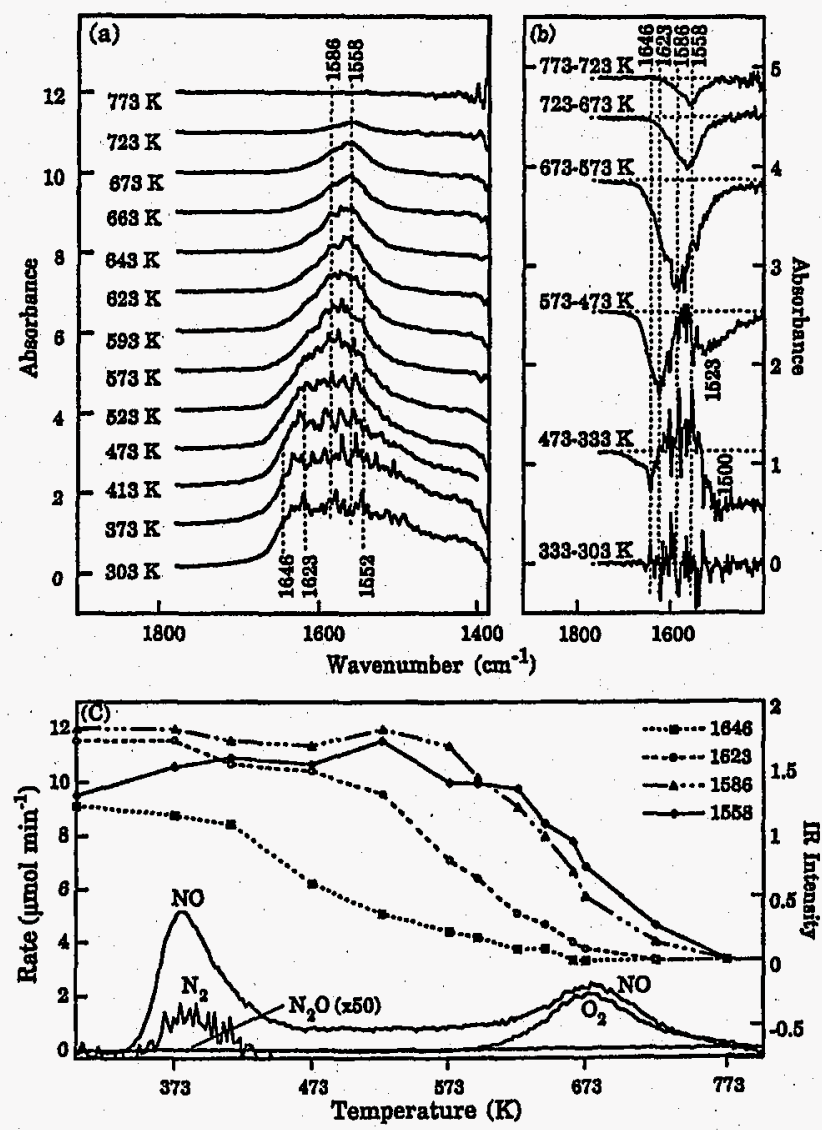

Figure 2. (a) Infrared spectra during NO TPD/R on oxidized 1 wt $\%$ $\mathrm{Tb}-\mathrm{Pt} / \mathrm{Al}_{2} \mathrm{O}_{3}$ at a heating rate of $20 \mathrm{~K} \mathrm{~min}^{-1}$ from 303 to $773 \mathrm{~K}$. (b) Spectral differences. (c) Rate of elution for gaseous species from the IR cell and variation of IR intensities with temperatire.

determination of mass balance which provides information on the moles of gaseous reactant entering the reactor and those of gaseous products leaving the reactor. Figure $3 a$ shows the response of the IR reactor effluent composition. The number near each peak of the response indicates the amount (micromoles) of the species determined by the area under each peak multiplied by its calibration factor. The $500 \mu \mathrm{L}(20.1 \mu \mathrm{mol})$ NO pulses produced $\mathrm{N}_{2}$ and $\mathrm{N}_{2} \mathrm{O}$ at $673 \mathrm{~K}$. Lack of oxygen formation indicates that the catalytic cycle for the decomposition of $\mathrm{NO}$ to $\mathrm{N}_{2}$ and $\mathrm{O}_{2}$ was not complete; formation of gaseous $\mathrm{N}_{2}$ and $\mathrm{N}_{2} \mathrm{O}$ leaves oxygen from dissociated $\mathrm{NO}$ on the catalyst. The $500 \mu \mathrm{L}$ NO pulses were continued at $723 \mathrm{~K}$ in an attempt to facilitate oxygen desorption. The initial four $500 \mu \mathrm{L}$ and one $1 \mathrm{~mL}$ NO pulses produced only $\mathrm{N}_{2}$ as a product, and infrared spectra remain unchanged as the NO pulsed through the catalyst disk. The absence of variation of IR spectra indicates that (i) the residence time and concentration of adsorbates resulting from NO puises are too low for adsorbates to be detected by infrared spectroscopy or (ii) the adsorbates produced from the NO pulse are not in the IR-active form.

Figure 3a shows that $\mathrm{N}_{2} \mathrm{O}$ and $\mathrm{O}_{2}$ began to be produced at pulse VI. Further NO pulses led to increase in $\mathrm{O}_{2}$ production and decrease in $\mathrm{N}_{2} \mathrm{O}$ and $\mathrm{N}_{2}$ formation. Increase in $\mathrm{NO}$ at the effluent of the reactor indicates decrease in NO conversion. Time scale and MS intensity for the pulses VI, VII, and VIII are expanded in Figure $3 b$ to examine the lead/ag relationship in product formation. Elution of NO lagged behind the formation of $\mathrm{N}_{2}, \mathrm{~N}_{2} \mathrm{O}$, and $\mathrm{O}_{2}$. This behavior is in contrast to transient responses of $\mathrm{N}_{2}, \mathrm{~N}_{2} \mathrm{O}$, and $\mathrm{O}_{2}$ formation on $\mathrm{Cu}-\mathrm{ZSM}-5$ which shows that $\mathrm{O}_{2}$ formation lagged behind that of $\mathrm{N}_{2}$ and $\mathrm{N}_{2} \mathrm{O} .^{16}$

$\mathrm{NO}_{2}$ was not observed by mass spectroscopy during TPD/R and pulse reaction studies due to its small calibration factor. 

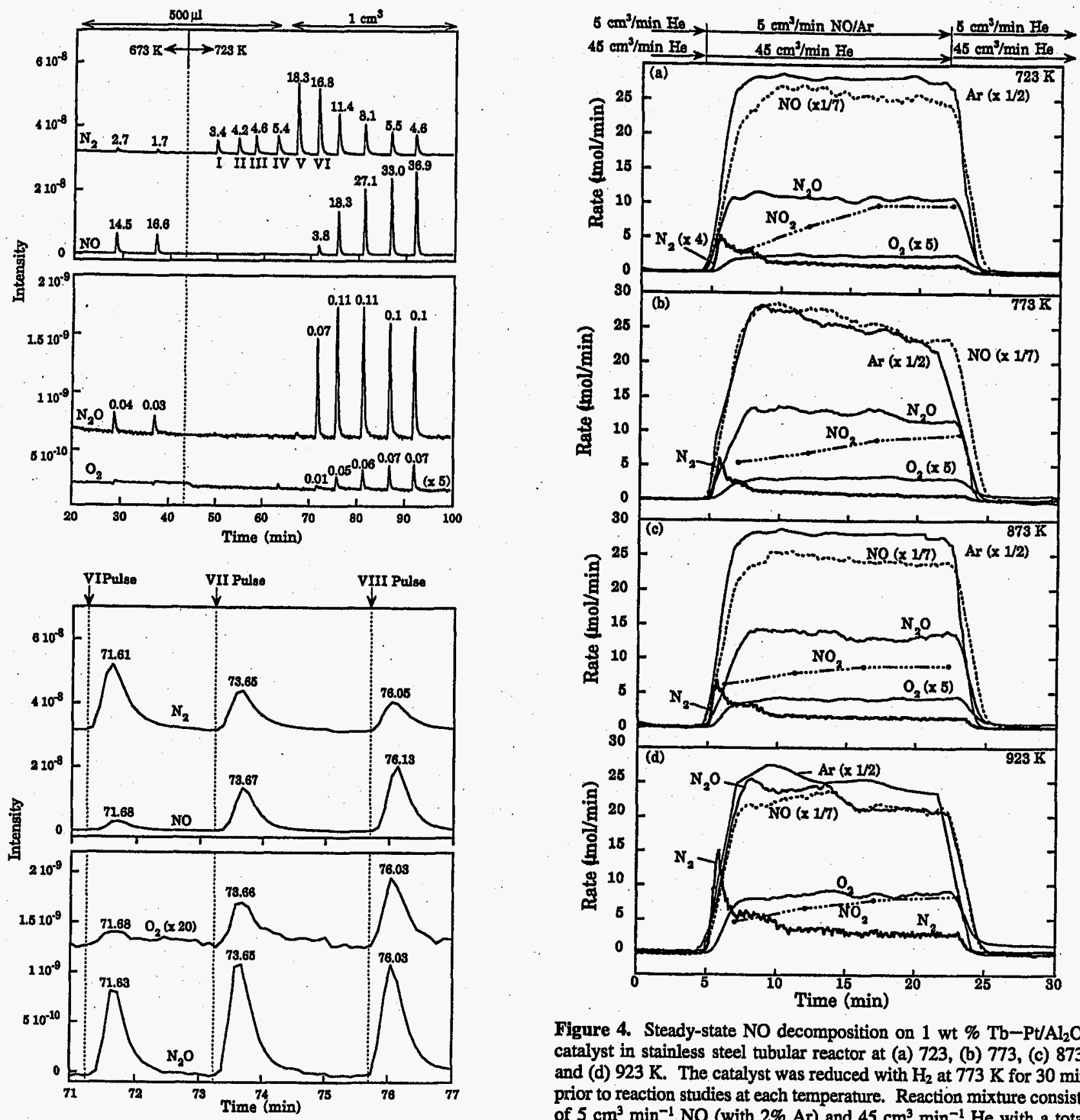

Figure 3. (a, top) MS response of the IR reactor effluent composition during the pulse $\mathrm{NO}$ reaction on $1 \mathrm{wt} \% \mathrm{~Tb}-\mathrm{Pt}_{\mathrm{Al}} \mathrm{O}_{3}$ at 673 and 723 $K$. The number near each peak of the response indicates the amount ( $\mu \mathrm{mol}$ ) of the species. (b, bottom) Pulses VI, VII, and VII in (a) at $723 \mathrm{~K}$.

The low $\mathrm{NO}_{2}$ calibration factor does not allow detection of low concentration of $\mathrm{NO}_{2}$ in the effluent of the $\mathbb{R}$ cell. Inability to accurate quantification of $\mathrm{NO}_{2}$ formation of gas chromatography and mass spectroscopy has presented serious problems in determining catalyst selectivity and mass balance between reactants and products in the literature.

In order to quantify $\mathrm{NO}_{2}$ formation and determine the steadystate catalyst activity and selectivity, the steady-state NO decomposition was carried out over the catalyst in a tubular reactor by step switch of the inlet flow from steady-state He flow to NO/Ar flow. Ar is added to NO stream to determine the flow pattern of reactant flow during the step switch. The reactor effluent is monitored by mass spectrometer, GC/MS, and infrared spectroscopy with a gaseous IR cell. The MS intensity profiles of the reactor effluent monitored by mass

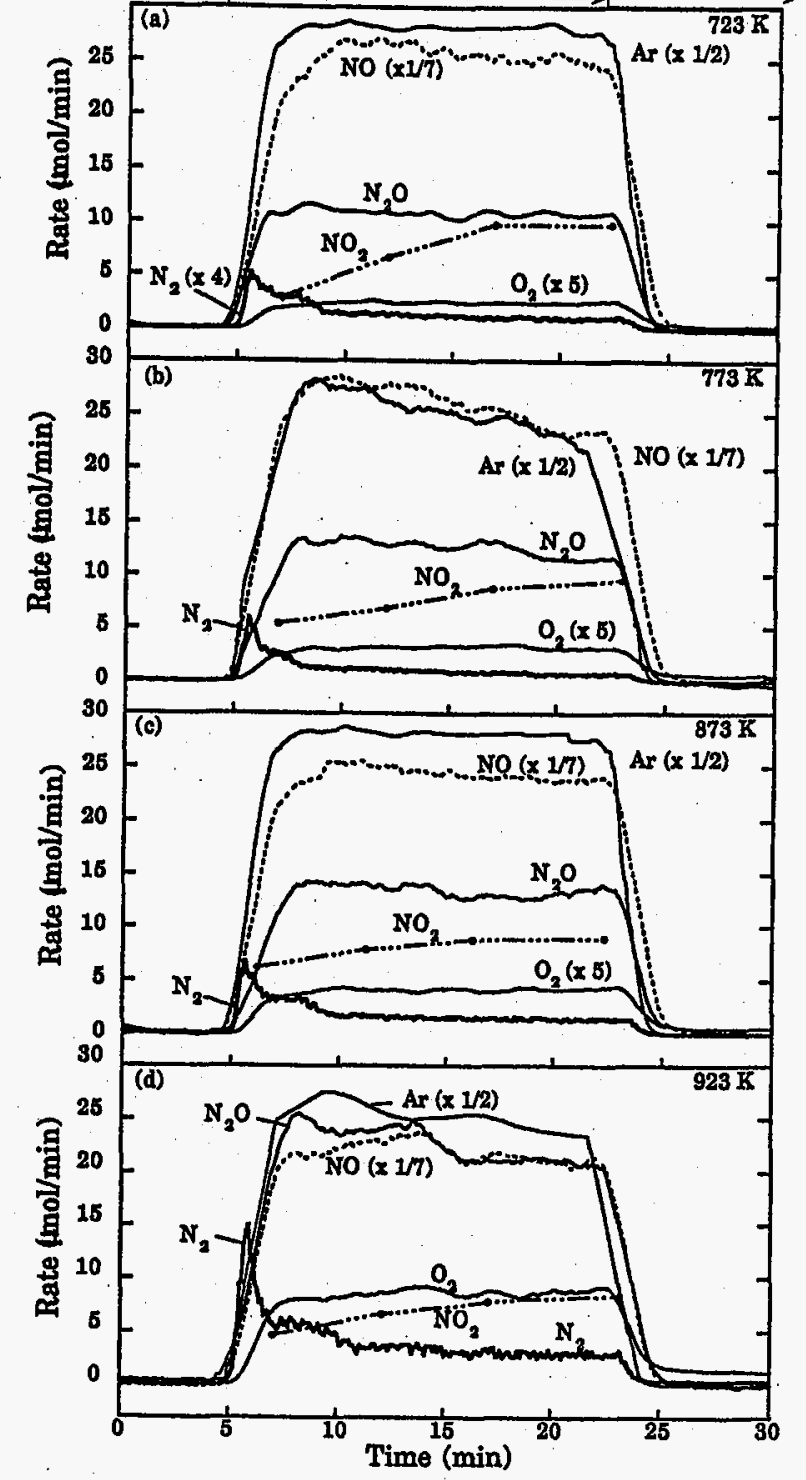

Figure 4. Steady-state $\mathrm{NO}$ decomposition on $1 \mathrm{wt} \% \mathrm{~Tb}-\mathrm{Pt} / \mathrm{Al}_{2} \mathrm{O}_{3}$ catalyst in stainless steel tubular reactor at (a) 723 , (b) 773 , (c) 873 , and (d) $923 \mathrm{~K}$. The catalyst was reduced with $\mathrm{H}_{2}$ at $773 \mathrm{~K}$ for $30 \mathrm{~min}$ prior to reaction studies at each temperature. Reaction mixture consists of $5 \mathrm{~cm}^{3} \mathrm{~min}^{-1}$ NO (with $2 \% \mathrm{Ar}$ ) and $45 \mathrm{~cm}^{3} \mathrm{~min}^{-1} \mathrm{He}$ with a total flow rate of $50 \mathrm{~cm}^{3} \mathrm{~min}^{-1}$.

spectroscopy were adjusted to the elution rate profiles by quantitative measurement of $\mathrm{N}_{2} \mathrm{O}, \mathrm{N}_{2}, \mathrm{O}_{2}$, and $\mathrm{NO}$ by GC/MS and that of $\mathrm{NO}, \mathrm{N}_{2} \mathrm{O}$, and $\mathrm{NO}_{2}$ by infrared spectroscopy. In order to ensure reproducibility, the catalyst was reduced by hydrogen flow at $773 \mathrm{~K}$ prior to step switch reaction studies at each temperature.

Figure 4 shows that $\mathrm{N}_{2}$ formation gave an overshoot response while $\mathrm{N}_{2} \mathrm{O}$ and $\mathrm{O}_{2}$ formation increased gradually to steady state between 723 and $923 \mathrm{~K}$ following the step switch of flow from $\mathrm{He}$ to NO/Ar. The overshoot of $\mathrm{N}_{2}$ indicates the high initial activity of NO decomposition due to the reduced state of Pt. $\mathrm{NO}_{2}$ was determined by a large gaseous $\mathrm{IR}$ cell with a long $\mathrm{IR}$ beam path which does not allow determination of transient formation of $\mathrm{NO}_{2}$. A separate calibration run shows that $\mathrm{NO}_{2}$ was produced from reaction of $\mathrm{O}_{2}$ with NO. ${ }^{16}$ The results are consistent with those reported by $\mathrm{Li}$ and Hall, who has demonstrated that $\mathrm{O}_{2}$ produced from NO decomposition reacts with NO to produce $\mathrm{NO}_{2}{ }^{3}$ Product yields in Table 1 shows the selectivity to $\mathrm{NO}_{2}$ decreased with increasing temperature. 
TABLE 1: NO Conversion (\%) and Yields (\%) versus Temperature for the NO Decomposition

\begin{tabular}{cccccc}
\hline & & \multicolumn{4}{c}{ yields $^{a}(\%)$} \\
\cline { 3 - 6 } temp (K) & NO conversion & $\mathrm{N}_{2}$ & $\mathrm{~N}_{2} \mathrm{O}$ & $\mathrm{O}_{2}$ & $\mathrm{NO}_{2}$ \\
\hline 673 & 11.88 & 0.00 & 32.35 & 1.72 & 35.29 \\
723 & 16.05 & 0.77 & 34.10 & 1.57 & 30.26 \\
773 & 16.99 & 2.01 & 34.18 & 1.79 & 27.62 \\
873 & 18.60 & 3.67 & 34.39 & 2.24 & 23.88 \\
923 & 27.75 & 4.56 & 37.97 & 15.58 & 14.94
\end{tabular}

- Yield $=$ (number of moles produced)/(number of moles of NO reacted) $\times 100 \%$.

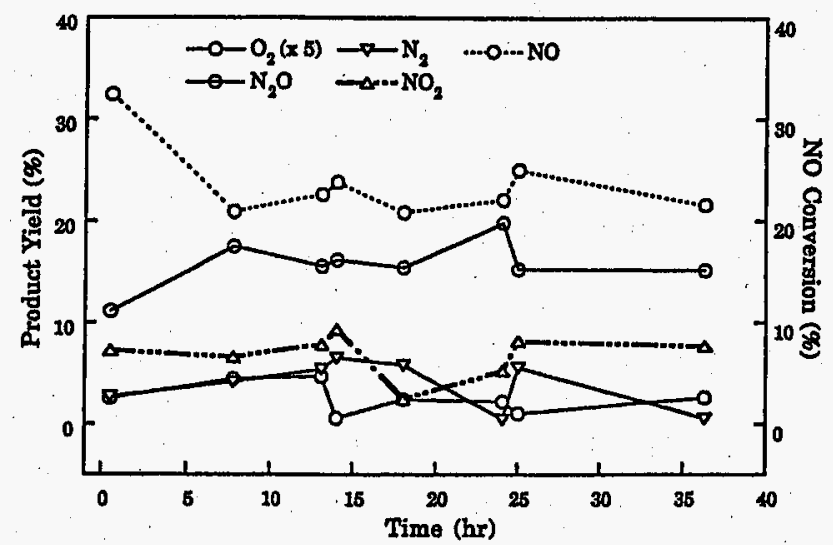

Figure 5. NO conversion and product yield versus reaction time at $873 \mathrm{~K}$. Reaction mixture consists of $5 \mathrm{~cm}^{3} \mathrm{~min}^{-1}$ NO (with $2 \% \mathrm{Ar}$ ) and $45 \mathrm{~cm}^{3} \mathrm{~min}^{-1} \mathrm{He}$ with a total flow rate of $50 \mathrm{~cm}^{3} \mathrm{~min}^{-1}$.

Long-term catalyst deactivation study at $873 \mathrm{~K}$ in Figure 5 demonstrates that the catalyst exhibits the stable activity and selectivity after initial $8 \mathrm{~h}$ of reaction.

\section{Conclusions}

Combined TPD/R with in situ IR study reveals that both Tb$\mathrm{Pt} / \mathrm{Al}_{2} \mathrm{O}_{3}$ and air-treated $\mathrm{Tb}-\mathrm{Pt} / \mathrm{Al}_{2} \mathrm{O}_{3}$ catalysts exhibit $\mathrm{O}_{2}$ desorption profile centered at $693 \mathrm{~K}$. The $\mathrm{O}_{2}$ desorption is resulted from decomposition of chelating bidentate nitrato which is produced from the direct exposure of the catalysts to gaseous
NO. The Tb-Pt/Al ${ }_{2} \mathrm{O}_{3}$ catalysts which exhibit low-temperature $\mathrm{O}_{2}$ desorption show the activity for $\mathrm{NO}$ decomposition at temperatures above $723 \mathrm{~K}$ under the pulse reaction and steadystate condition. The catalyst exhibits steady-state activity and selectivity for $37 \mathrm{~h}$ at $873 \mathrm{~K}$. Further study is underway to determine the effect of air, $\mathrm{H}_{2} \mathrm{O}$, and $\mathrm{SO}_{2}$ on the $\mathrm{NO}$ decomposition under steady-state flow condition.

Acknowledgment. The authors gratefully acknowledge financial support for this research from the U.S. Department of Energy Grant DE-FG22-95PC95224.

\section{References and Notes}

(1) Hightower, J. W.; Van Leirsburg, D. A. In The Catalytic Chemistry of Nitrogen Oxides; Klimisch, R. L., Larson, J. G., Eds.; Plenum Press: New York, 1975; p 63.

(2) Iwamoto, M. In Studies in Surface Science and Catalysis; Misono, M., Moro-oka, Y., Kimura, S., Eds.; Elsevier: Amsterdam, 1990; Vol. 54, p 121.

(3) Li, Y.; Hall, W. K. J. Phys. Chem. 1990, 94, 6140.

(4) Li, Y.; Armor, J. N. Appl. Catal. 1991, 76, L1.

(5) Kung, M. C. Catal. Lett. 1993, 18, 111.

(6) Aylor, A. W.; Larsen, S. C.; Reimer, J. A.; Bell, A. T. J. Catal. $1995,157,592$.

(7) Tan, C.-D.; Krishnamurthy, R.; Chuang, S. S. C. Abstract of 33rd Annual Spring Symposium of the Pittsburgh-Cleveland Catalysis Society, Pittsburgh, PA, May 10-1, 1995.

(8) Chuang, S. S. C.; Krishnamurthy, R.; Tan, C.-D.; Brundage, M Abstract of 7th Japan-China-USA Symposium on Catalysis, Tokyo, Japan, July 26-28, 1995; p 0-29.

(9) Kyomasu, A.; Okuhara, T.; Misono, M. Nippon Kagaku Kaishi $1991,5,651$.

(10) Takasu, Y.; Yoko-o, T.; Matsui, M.; Matsuda, Y.; Toyoshima, I. J. Catal. 1982, 77, 485.

(11) Takasu, Y.; Matsui, M.; Tamura, H.; Kawamura, S.; Matsuda, Y.; Toyoshima, I. J. Catal. 1981, 69, 51.

(12) Chuang, S. S. C.; Brundage, M. A.; Balakos, M. W.; Srinivas, G. Appl. Spectrosc. 1995, 49 (8), 1151.

(13) Nakamoto, K. Infrared and Raman Spectra of Inorganic and Coordination Compounds, 4th ed.; John Wiley \& Sons: New York, 1986.

(14) Fisher, G. B.; DiMaggio, C. L.; Beck, D. D. In New Frontiers in Catalysis; Proceedings of the 10th International Congress on Catalysis, 1992; Guczi, L., Solymosi, F., Tetenyi, P., Eds.; Akademiai Kiado: Budapest, Hungary, 1993; Part A, p 383.

(15) Gland, J. L.; Sexton, B. A.; Fisher, G. B. Surf. Sci. 1980, 95, 587.

(16) Konduru, U. V. M.S. Thesis Preliminary Study, The University of Akron, 1996. 


\title{
In Situ Infrared Study of Catalytic Decomposition of NO on Carbon- Supported Rh and Pd Catalysts
}

\author{
Khalid Almusaiteer, Ram Krishnamurthy and Steven S. C. Chuang* \\ Department of Chemical Engineering \\ The University of Akron, Akron, OH 44325-3906.
}

\begin{abstract}
The direct catalytic decomposition of $\mathrm{NO}$ on $\mathrm{Rh} / \mathrm{Al}_{2} \mathrm{O}_{3}, \mathrm{Rh} / \mathrm{C}, \mathrm{Pd} / \mathrm{Al}_{2} \mathrm{O}_{3}$, and $\mathrm{Pd} / \mathrm{C}$ catalysts was investigated at $673 . \mathrm{K}$ by in situ infrared (IR) coupled with mass spectroscopy (MS). NO decomposition on these catalysts initially produced $\mathrm{N}_{2}$ and adsorbed oxygen. Different catalysts exhibit different capability for manipulating adsorbed oxygen. $\mathrm{Rh}^{\prime} / \mathrm{Al}_{2} \mathrm{O}_{3}$ shows little activity for oxygen desorption, resulting in loss of catalyst activity; $\mathrm{Rh} / \mathrm{C}$ shows the ability for promoting the adsorbed oxygen-carbon reaction, removing oxygen in the form of $\mathrm{CO}_{2}$; $\mathrm{Pd} / \mathrm{Al}_{2} \mathrm{O}_{3}$ shows some activity for $\mathrm{O}_{2}$ desorption. Use of carbon as a support for $\mathrm{Pd}$ promotes $\mathrm{O}_{2}$ desorption, resulting in improvement of NO decomposition activity. The in situ IR results provide evidence to support the behavior of adsorbed oxygen on carbon-supported $\mathrm{Rh}$ and $\mathrm{Pd}$ catalysts.
\end{abstract}

Keywords: infrared spectroscopy; NO decomposition; oxygen desorption; $\mathrm{Rh}$; $\mathrm{Pd}$; activated carbon; adsorption; adsorbed NO.

\section{Introduction}

NO is a major pollutant in the exhaust of various combustion processes. The growing concerns for the environment have resulted in increasingly stringent NO emission standards [13]. Removal of NO from the exhaust streams of automobiles, power plants, and other combustion processes has become a challenging task.

Depending on the nature of the combustion process, various approaches for NO removal have been developed. The catalytic approaches for the removal of NO include (i) the reaction of NO with $\mathrm{CO}[1-4]$, (ii) selective catalytic reduction with $\mathrm{NH}_{3}$ and hydrocarbons $[5,6]$, and (iii) the direct decomposition of nitric oxide [7-10]. The advantages and disadvantages of each approach are listed in Table 1.

" Corresponding author. Tel. (330)972-6993, Fax. (330)972-5856. 
The direct decomposition of NO, $2 \mathrm{NO} \rightarrow \mathrm{N}_{2}+\mathrm{O}_{2}$, is the most attractive approach for $\mathrm{NO}$ removal because of its simplicity [7]. It is thermodynamically favorable at temperatures below $2000 \mathrm{~K}$. For the NO decomposition catalyst development, the two critical issues to be addressed are catalyst activity and durability [11].

Studies on the proposed elementary steps for NO decomposition have revealed that the low activity of the catalysts is due to their inability to desorb oxygen produced from NO dissociation $[8,10]$. Oxygen from dissociated NO is strongly bonded to the catalyst surface, poisoning NO dissociation sites and inhibiting further NO dissociation. Various approaches to remove adsorbed oxygen from the NO dissociation sites include: (i) thermal desorption, (ii) autoreduction of the surface in He flow [8], and (iii) spillover of adsorbed oxygen [10]. One possible approach is to use carbon as a support for the catalyst system, facilitating the removal of oxygen by the formation of $\mathrm{CO}_{2}$. Recent studies have shown that activated carbon has the capability to reduce $\mathrm{NO}$ to from $\mathrm{N}_{2}$ and $\mathrm{CO}_{2}$ [12-14]. Near $100 \%$ conversions of $\mathrm{NO}$ were achieved using a Ni or Co catalyst supported on activated carbon at temperatures above $713 \mathrm{~K}$. The NO conversions on carbon supported catalysts decreased in the presence of $\mathrm{O}_{2}[15]$.

Rhodium (Rh) and Palladium (Pd), the major components in three way catalytic converters, have shown excellent activity for the dissociation of adsorbed NO. To determine the feasibility of using carbon for removal of adsorbed oxygen on $\mathrm{Rh}$ and $\mathrm{Pd}$, we have examined the activity of carbon- and $\mathrm{Al}_{2} \mathrm{O}_{3}$-supported $\mathrm{Rh}$ and $\mathrm{Pd}$ catalysts and the nature of the adsorbate for the NO decomposition reaction. We have found that carbon promotes the $\mathrm{N}_{2}$ and $\mathrm{CO}_{2}$ formation over $\mathrm{Rh}$ catalyst while enhancing $\mathrm{N}_{2}$ and $\mathrm{O}_{2}$ formation on $\mathrm{Pd}$ catalyst. 


\section{Experimental}

The $2 \mathrm{wt} \% \mathrm{Rh} / \mathrm{Al}_{2} \mathrm{O}_{3}, 2 \mathrm{wt} \% \mathrm{Rh} / \mathrm{C}, 2 \mathrm{wt} \% \mathrm{Pd} / \mathrm{Al}_{2} \mathrm{O}_{3}$, and $2 \mathrm{wt} \% \mathrm{Pd} / \mathrm{C}$ catalysts were prepared by incipient wetness impregnation technique of large surface area $\gamma-\mathrm{Al}_{2} \mathrm{O}_{3}$ (Alfa Products, $100 \mathrm{~m}^{2} / \mathrm{g}$ surface area) and carbon (activated carbon, Ambersorb 563, Rohm \& Haas, $550 \mathrm{~m}^{2} / \mathrm{g}$ surface area) with $\mathrm{RhCl}_{3}$ or $\mathrm{PdCl}_{2}$ solutions. The ratio of the volume of the solution to the weight of the support used in the impregnation step was $1 \mathrm{~cm}^{3}$ to $1 \mathrm{~g}$. The catalysts were dried overnight in air at $303 \mathrm{~K}$. They were then calcined in air at $673 \mathrm{~K}$ for $8 \mathrm{~h}$ and reduced in flowing $\mathrm{H}_{2}$ at $673 \mathrm{~K}$ for $8 \mathrm{~h}$. The catalysts prepared were characterized by X-Ray Diffraction (XRD) and the crystallite size was determined. The crystallite sizes of $\mathrm{Rh}$ in $\mathrm{Rh} / \mathrm{Al}_{2} \mathrm{O}_{3}$ and $\mathrm{Pd}$ in $\mathrm{Pd} / \mathrm{Al}_{2} \mathrm{O}_{3}$ were found to be $50 \AA$ and $64 \AA$, respectively. The crystallite sizes of $\mathrm{Rh}$ in $\mathrm{Rh} / \mathrm{C}$ and $\mathrm{Pd}$ in $\mathrm{Pd} / \mathrm{C}$ were found to be $47 \AA$ and $70 \AA$, respectively.

$\mathrm{Al}_{2} \mathrm{O}_{3}$-supported catalysts were pressed in the form of self-supporting disks (40 mg each); one of the disks was placed in the infrared (IR) cell for in situ transmission IR studies and the other two disks were broken down into flakes and placed in the exit line of the IR reactor cell [16]. The additional catalyst disks were used to increase the amount of desorbing species and conversions to obtain a strong signal in the Mass Spectrometer (MS). Carbon-supported catalysts were diluted with $\mathrm{KBr}$ (catalyst: $\mathrm{KBr}=1: 10$ ) and $20 \mathrm{mg}$ of the solid mixture was placed in the Diffuse Reflectance Infrared Fourier Transform (DRIFT) cell in powder form for in situ IR studies. Additional carbon supported catalyst $(90 \mathrm{mg})$ was placed in a tubular reactor, which was connected in series with the DRIFT cell.

The catalysts were reduced in situ in flowing $\mathrm{H}_{2}$ at $673 \mathrm{~K}$ for $1 \mathrm{~h}$. Following the in situ reduction of the catalyst, the NO decomposition study was carried out at $673 \mathrm{~K}$. The catalyst 
was exposed initially to He flow. A 4-port valve was used to switch the He flow to $1 \%$ NO in $\mathrm{He}$ flow in a step mode. This NO step switch technique allows investigating the sequence of adsorbate and product formation during the NO decomposition reaction on the catalyst surface. Fourier Transform Infrared Spectroscopy (FTIR) was used to monitor the adsorbate concentrations and MS to analyze the change in the concentration of the gaseous product from the effluent of the IR reactor cell.

\section{Results}

\section{NO decomposition on $\mathrm{Rh} / \mathrm{Al}_{2} \mathrm{O}_{3}$}

Fig. 1a shows the MS analysis of the IR reactor cell effluent during the $1 \%$ NO step switch reaction studies on $\mathrm{Rh} / \mathrm{Al}_{2} \mathrm{O}_{3}$ at $673 \mathrm{~K}$. The IR spectra of the adsorbates corresponding to the MS profiles are shown in Fig. 2. To determine the role of adsorbates in the reaction, the variation in the IR intensity of major adsorbates was plotted versus time in Fig. 1b. Absence of adsorbed species prior to the step switch indicates that the catalyst surface was clean. The step switch from $\mathrm{He}$ to $1 \% \mathrm{NO}$ at time $=0$ resulted in the formation of $\mathrm{N}_{2}$. The absence of $\mathrm{NO}$ in the initial period is a result of near $100 \%$ conversion. Ar, the species added in $1 \%$ NO flow, shows that a near perfect step switch was achieved. A close examination of MS and IR intensity profiles in Fig. $1 \mathrm{a}$ and $\mathrm{b}$ revealed that the NO step switch reaction may be divided into three stages. Stage 1 comprises of nearly complete NO conversions on the reduced metal surface resulting in the depletion of all the NO adsorbates in the $0-10$ min period; stage 2 is the emergence of NO adsorbates in the 10-31 min period; and stage 3 is the appearance and slow growth of gaseous NO profile after 31 min. The wavering behavior of the MS profile of $\mathrm{N}_{2}$ during stage 1 and 2 suggests the unsteady behavior of the following reaction: 


$$
2 \mathrm{Rh}+2 \mathrm{NO} \rightarrow 2 \mathrm{Rh}-\mathrm{O}+\mathrm{N}_{2}
$$

Reaction (1) is a global reaction and its elementary steps will be discussed later.

During stage $2, \mathrm{Rh}-\mathrm{NO}^{+}$at $1893 \mathrm{~cm}^{-1}, \mathrm{Rh}^{0}-\mathrm{NO}^{-}$at $1644 \mathrm{~cm}^{-1}$, nitrate ion at $1361 \mathrm{~cm}^{-1}$ and bridging bidentate at $1540 \mathrm{~cm}^{-1}$ began to develop at $11 \mathrm{~min}$ as a result of modification of $\mathrm{Rh}$ surface by adsorbed oxygen, i.e., $\mathrm{Rh}-\mathrm{O}$. $\mathrm{Rh}-\mathrm{O}$ slowly converts the reduced $\mathrm{Rh}$ sites to $\mathrm{Rh}^{+}$sites, which chemisorb NO as $\mathrm{Rh}-\mathrm{NO}^{+}$. Fig. la shows that as the $\mathrm{Rh}_{-} \mathrm{NO}^{+}$intensity approached to $90 \%$ of its saturated level, gaseous NO emerged at stage 3 indicating the loss of catalyst activity. The loss of NO decomposition activity allows populating of non-dissociated NO on the surface, such as $\mathrm{Rh}^{0}-\mathrm{NO}^{-}$and $\mathrm{Rh}-\mathrm{NO}^{+} . \mathrm{Rh}^{0}-\mathrm{NO}^{-}$and $\mathrm{Rh}-\mathrm{NO}^{+}$may react with adsorbed $\mathrm{N}$, already existing on the surface, resulting in $\mathrm{N}_{2} \mathrm{O}$ formation. The formation of $\mathrm{N}_{2} \mathrm{O}$ from adsorbed $\mathrm{N}$ and adsorbed NO is further supported by the crossover between the decrease in the $\mathrm{N}_{2}$ profile and the increase in the NO profile as shown in Fig.1a.

\section{NO decomposition on $\mathrm{Rh} / \mathrm{C}$}

Fig. 3a shows the MS analysis of the IR reactor cell effluent during the $1 \%$ NO step switch reaction studies on $\mathrm{Rh} / \mathrm{C}$ at $673 \mathrm{~K}$. The IR spectra of the adsorbates corresponding to the MS profiles are shown in Fig. 4. The step switch from He to $1 \%$ NO resulted in $100 \%$ conversion of $\mathrm{NO}$ and the formation of $\mathrm{N}_{2}$ during the first $50 \mathrm{~min}$ of the reaction. The step switch also caused the development of the adsorbates at $1400,1277,1151$ and $1101 \mathrm{~cm}^{-1}$ and approached saturation at 20 min as shown in Figs. $3 \mathrm{~b}$ and 4 . The band at $1400 \mathrm{~cm}^{-1}$ has been assigned to oxygen species on carbon surface in the form of esters, phenols or carbonates $[17,18]$. The band at $1277 \mathrm{~cm}^{-1}$ could also be due to oxygen species on the surface, resulting from $\mathrm{C}-\mathrm{O}$ stretches in species like aromatic ethers. The bands at 1151 and $1101 \mathrm{~cm}^{-1}$ were 
assigned to the $\mathrm{C}-\mathrm{N}$ species on the surface [19]. The assignment of these species was further verified by IR studies of $\mathrm{O}_{2}$ and $\mathrm{N}_{2}$ adsorption on carbon supported catalysts surface [20].

Comparison of the results in Figs. 1 and 3 shows that the NO reaction on $\mathrm{Rh} / \mathrm{C}$ differed from that on $\mathrm{Rh} / \mathrm{Al}_{2} \mathrm{O}_{3}$ in the development and formation of both adsorbates and products. The major products on $\mathrm{Rh} / \mathrm{C}$ are $\mathrm{N}_{2}$ and $\mathrm{CO}_{2} . \mathrm{CO}_{2}$ emerged at the moment when the $\mathrm{C}-\mathrm{O}$ species at $1402 \mathrm{~cm}^{-1}$ showed a drastic increase in its intensity. The result suggests that the $\mathrm{C}-\mathrm{O}$ species is a precursor toward the $\mathrm{CO}_{2}$ formation.

\section{NO decomposition on $\mathrm{Pd} / \mathrm{Al}_{2} \mathrm{O}_{3}$}

Fig. 5a shows the MS analysis of the IR reactor cell effluent during the $1 \%$ NO step switch reaction studies on $\mathrm{Pd} / \mathrm{Al}_{2} \mathrm{O}_{3}$ at $673 \mathrm{~K}$. The IR spectra of the adsorbates corresponding to the MS profiles are shown in Fig. 6. Like the reaction on $\mathrm{Rh} / \mathrm{Al}_{2} \mathrm{O}_{3}$, the NO decomposition process on $\mathrm{Pd} / \mathrm{Al}_{2} \mathrm{O}_{3}$ can be divided into three stages. Stage 1 is near complete conversions of NO; stage 2 is the NO adsorbate development; and stage 3 is the emergence of $\mathrm{NO}$ and $\mathrm{O}_{2}$. The major difference between $\mathrm{Pd} / \mathrm{Al}_{2} \mathrm{O}_{3}$ and $\mathrm{Rh} / \mathrm{Al}_{2} \mathrm{O}_{3}$ is that $\mathrm{Pd} / \mathrm{Al}_{2} \mathrm{O}_{3}$ catalyzes significant amount of $\mathrm{O}_{2}$.

The development of $\mathrm{Pd}-\mathrm{NO}^{+}$at $1802 \mathrm{~cm}^{-1}$ at $2.9 \mathrm{~min}$ in stage 2 reflects an increase in the concentration of $\mathrm{Pd}^{+}$produced by adsorbed oxygen from $\mathrm{NO}$ dissociation. As the intensity of $\mathrm{Pd}-\mathrm{NO}^{+}$reached a constant level as shown in Fig. $5 \mathrm{~b}$, gaseous $\mathrm{NO}$ and $\mathrm{O}_{2}$ emerged while the reaction process moved to stage 3 .

\section{NO decomposition on $\mathrm{Pd} / \mathrm{C}$}

Fig. 7a shows the MS analysis of the reactor effluent during the $1 \%$ NO step switch reaction studies on $\mathrm{Pd} / \mathrm{C}$ at $673 \mathrm{~K}$. The IR spectra of the adsorbates corresponding to the MS profiles are shown in Fig. 8. The step switch to $1 \%$ NO resulted in near $100 \%$ conversions of 
$\mathrm{NO}$ and the formation on $\mathrm{N}_{2}$, during 52 min of the reaction. The development of $\mathrm{Pd}^{-\mathrm{NO}^{+}}$at 1770 $\mathrm{cm}^{-1}, \mathrm{C}=\mathrm{O}$ at $1655 \mathrm{~cm}^{-1}[12,18], \mathrm{C}-\mathrm{O}$ at $1398 \mathrm{~cm}^{-1}$ and $\mathrm{C}-\mathrm{N}$ at $1132 \mathrm{~cm}^{-1}$ was also observed. The appearance of $\mathrm{Pd}-\mathrm{NO}^{+}$reflects an increase in the concentration of $\mathrm{Pd}^{+}$produced by adsorbed oxygen from NO dissociation. As in $\mathrm{Pd} / \mathrm{Al}_{2} \mathrm{O}_{3}$, a significant amount of $\mathrm{O}_{2}$ was produced with the emergence of gaseous NO. Comparison of the results of $\mathrm{Rh} / \mathrm{C}$ in Fig.3a and $\mathrm{Pd} / \mathrm{C}$ in Fig. 7a, reveals that $\mathrm{Rh} / \mathrm{C}$ catalyzes the formation of $\mathrm{CO}_{2}$, but $\mathrm{Pd} / \mathrm{C}$ catalyzes the formation of $\mathrm{O}_{2}$.

\section{Discussion}

Table 2 shows the activity and selectivity of the different catalysts for the NO decomposition. The amount of oxygen adsorbed from, $2 \mathrm{NO}+2 \mathrm{~S} \rightarrow \mathrm{N}_{2}+2 \mathrm{O}-\mathrm{S}$, was normalized by catalyst weight. It can be inferred from Table 2 that the carbon-supported catalysts have the ability to uptake more oxygen than alumina supported catalysts. Comparison of the amount of adsorbed oxygen with the number of metal surface atoms (Table 2) reveals that the oxygen adsorbed on the surface diffuses to the bulk causing the formation of bulk oxides.

The behavior of the catalyst (i.e. activity, selectivity and adsorbates on the catalyst surface) may be interpreted using the proposed mechanism listed in Table 3. Formation of different products can be explained by the structure of adsorbates and their reaction pathways on the catalyst surface. Prior to the emergence of gaseous NO (i.e. stage 1), instantaneous dissociation of adsorbed NO (step 2 in Table 3) takes place on both $\mathrm{Pd}^{0}$ and $\mathrm{Rh}^{0}$ surfaces of the $\mathrm{Al}_{2} \mathrm{O}_{3}$ supported catalysts. Facile nature of the $\mathrm{NO}$ dissociation allows the immediate formation of $\mathrm{N}_{2}$ (step 3) and near $100 \%$ conversions of $\mathrm{NO}$ on the catalyst surface. Absence of steric crowding of adsorbed NO molecules on the catalyst surface is attributed to the facileness of step 
2. The instantaneous consumption of the precursor adsorbates for the NO dissociation yielded no adsorbate IR bands, preventing verification of the nature of the NO adsorbate in step 2 .

Our previous transient studies have revealed that $\mathrm{Rh}^{0}-\mathrm{NO}^{-}$at $1644 \mathrm{~cm}^{-1}$ and $\mathrm{Pd}^{0}-\mathrm{NO}$ at $1745 \mathrm{~cm}^{-1}$ are the active adsorbates for NO dissociation to form adsorbed $\mathrm{N}$ and adsorbed $\mathrm{O}$ during the NO-CO reaction $[21,22]$. It is expected that the same adsorbates may decompose in the absence of $\mathrm{CO}$ and serve as the active adsorbates for $\mathrm{NO}$ decomposition. For $\mathrm{Rh} / \mathrm{Al}_{2} \mathrm{O}_{3}$ catalyst, $\mathrm{Rh}-\mathrm{NO}^{+}$was not the active adsorbate for $\mathrm{NO}$ dissociation. As it approached the saturated level, $\mathrm{Rh} / \mathrm{Al}_{2} \mathrm{O}_{3}$ began losing its activity for $\mathrm{NO}$ decomposition. The same trend was observed for $\mathrm{Pd}-\mathrm{NO}^{+}$and $\mathrm{NO}$ conversion activity over $\mathrm{Pd} / \mathrm{Al}_{2} \mathrm{O}_{3}$.

The formation of $\mathrm{N}_{2} \mathrm{O}$ (step 5) requires both adsorbed $\mathrm{N}$ and adsorbed NO. Our previous studies have shown this step takes place on the reduced metal sites [21]. Although different amounts of $\mathrm{N}_{2} \mathrm{O}$ were produced on these four catalysts, all the $\mathrm{N}_{2} \mathrm{O}$ formation occurred near the crossover point where the $\mathrm{N}_{2}$ profile decreased and the NO profile increased. The results indicate that $\mathrm{N}_{2} \mathrm{O}$ formed at the optimum concentration of adsorbed $\mathrm{N}$ and adsorbed NO.

The lack of oxygen formation (step 6) during the 100\% NO conversion (i.e. stage 1 on these four catalysts) suggests that the NO conversion to $\mathrm{N}_{2}$ at this stage is not a catalytic process instead it is a stoichiometric reaction as shown in reaction (1). A process is defined catalytic when active sites are regenerated and the product formation is continuous. The absence of oxygen desorption during the high $\mathrm{NO}$ conversion is further evidenced by the absence of $\mathrm{NO}_{2}$ formation (step 7). It has been well established that $\mathrm{NO}_{2}$ can be formed from either step 7 or gas phase reaction of $\mathrm{NO}$ with $\mathrm{O}_{2}$. The observations of the present study agreed well with several studies, which have suggested that adsorbed $\mathrm{O}$ (i.e., $\mathrm{S}-\mathrm{O}$, where $\mathrm{S}$ is $\mathrm{Rh}$ or $\mathrm{Pd}$ ) remains on the surface $[10,23,24]$. Unless the catalyst has the ability to desorb oxygen, S-O from reaction (1) 
will accumulate on the surface and blocks the sites for NO dissociation resulting in the increase in the surface coverage of the IR-observable species (active and spectator adsorbate).

Interestingly, each of these four different catalysts exhibits different abilities to manipulate adsorbed oxygen. $\mathrm{Rh} / \mathrm{Al}_{2} \mathrm{O}_{3}$ shows the weakest oxygen desorption capability, letting majority of oxygen to be accumulated on the Rh surface and losing NO decomposition activity. The $\mathrm{Rh} / \mathrm{C}$ catalyst exhibits the ability of spilling over the adsorbed $\mathrm{O}$ from $\mathrm{Rh}$ surface onto the carbon support and reacting with carbon to produce $\mathrm{CO}_{2}$ as in step 8 (i.e., gasification of the carbon). Production of $\mathrm{CO}_{2}$ in Fig. 3a appears to result from migration of adsorbed oxygen onto the carbon surface to form the $\mathrm{C}-\mathrm{O}$ species at 1277 and $1402 \mathrm{~cm}^{-1}$ as seen in Fig. $4 . \mathrm{Rh} / \mathrm{C}$ catalyst eventually lost its activity for $\mathrm{CO}_{2}$ formation, indicating that step 8 was interrupted. The loss of $\mathrm{Rh} / \mathrm{C}$ activity for $\mathrm{CO}_{2}$ formation is not surprising. As the carbon, located near the interface of $\mathrm{Rh}$ metal and carbon support, is being removed by $\mathrm{CO}_{2}$ formation, the $\mathrm{Rh}$ metal and carbon surface are expected to undergo dramatic modifications causing either decreasing $\mathrm{Rh}-\mathrm{C}$ interface or losing the contact between $\mathrm{Rh}$ and carbon. SEM studies have shown that NO reaction with carbon causes pitting [15].

Absence of step $8, \mathrm{CO}_{2}$ formation, on $\mathrm{Pd} / \mathrm{C}$ is in good agreement with the literature observations [25]. Pd shows the ability to desorb oxygen after saturation is reached as observed in $\mathrm{Pd} / \mathrm{Al}_{2} \mathrm{O}_{3}$ and $\mathrm{Pd} / \mathrm{C}$. The difference in the activity of the $\mathrm{Rh} / \mathrm{C}$ and $\mathrm{Pd} / \mathrm{C}$ catalysts towards desorption of oxygen could be due to the difference in the binding energy of oxygen to $\mathrm{Rh}$ (145 $\mathrm{kcal} / \mathrm{mol})$ and to $\mathrm{Pd}(87 \mathrm{kcal} / \mathrm{mol})[26,27]$. Thus, it may be easier for adsorbed oxygen on $\mathrm{Pd}$ to recombine for desorption as molecular oxygen. The difference in $\mathrm{Pd} / \mathrm{C}$ and $\mathrm{Pd} / \mathrm{Al}_{2} \mathrm{O}_{3}$ in oxygen desorption could be due to dispersion of metal particles (Table 2) or metal-support interaction. 
Lack of detailed structural surface information does not allow elucidation of the role of metalsupport interaction in the oxygen desorption.

As discussed earlier, the difference in the activity and selectivity of these four catalysts for the NO decomposition and reaction can be attributed to the difference in their capability to activate each elementary step listed in Table 3. The facile nature of NO dissociation (step 2) and $\mathrm{N}_{2}$ formation (step 3) points to steps 6 and 8 as the rate limiting steps for the overall reaction. $\mathrm{Rh}$ promotes step 8 for $\mathrm{CO}_{2}$ formation while $\mathrm{Pd}$ activates the step 6 for $\mathrm{O}_{2}$ formation on the carbon based catalysts. The rate of these steps, temperature-dependent, are clearly not fast enough compared to NO dissociation (step 2) resulting in the accumulation of adsorbed oxygen and then loss of the catalyst activity. We have also studied the reaction on $\mathrm{Rh} / \mathrm{Al}_{2} \mathrm{O}_{3}$ and $\mathrm{Pd} / \mathrm{Al}_{2} \mathrm{O}_{3}$ at 573 K. Decreasing the temperature from 673 to $573 \mathrm{~K}$ resulted in shortening the time for near $100 \%$ NO conversion (i.e. stage 1) for $\mathrm{Rh} / \mathrm{Al}_{2} \mathrm{O}_{3}$ from 31 to $19 \mathrm{~min}$ and for $\mathrm{Pd} / \mathrm{Al}_{2} \mathrm{O}_{3}$ from 20 to $14 \mathrm{~min}$. Increasing the reaction temperature on $\mathrm{Rh} / \mathrm{C}$ and $\mathrm{Pd} / \mathrm{C}$ to $773 \mathrm{~K}$ resulted in extending the activity for near $100 \%$ conversion for $\mathrm{Rh} / \mathrm{C}$ from 51 to $4 \mathrm{~h}$ and for $\mathrm{Pd} / \mathrm{C}$ from 52 to $75 \mathrm{~min}$. These differences could be attributed to the dependence of step 6 and 8 on temperature where high temperature facilitates the removal of surface (i.e. adsorbed) oxygen.

\section{Conclusions}

The results of this study are summarized as follows:

- NO decomposition on $\mathrm{Rh} / \mathrm{Al}_{2} \mathrm{O}_{3}$ produced $\mathrm{N}_{2}$ initially. As oxygen on the surface accumulated, $\mathrm{Rh}-\mathrm{NO}^{+}$at $1893 \mathrm{~cm}^{-1}, \mathrm{Rh}-\mathrm{NO}^{-}$at $1644 \mathrm{~cm}^{-1}$ developed, and catalyst lost $\mathrm{NO}$ decomposition activity. 
- NO decomposition on $\mathrm{Rh} / \mathrm{C}$ produced $\mathrm{N}_{2}$ and $\mathrm{CO}_{2}$. The adsorbed oxygen on the metal migrated to the support, resulting in the development of $\mathrm{C}-\mathrm{O}$ stretches at $1402 \mathrm{~cm}^{-1}$, which served as the precursor adsorbate for $\mathrm{CO}_{2}$ formation.

- NO decomposition on $\mathrm{Pd} / \mathrm{Al}_{2} \mathrm{O}_{3}$ produced $\mathrm{N}_{2}$ initially. As oxygen on the surface accumulated, Pd-NO ${ }^{+}$at $1802 \mathrm{~cm}^{-1}$ developed. Further accumulation of adsorbed oxygen caused oxygen desorption and partial loss of the catalyst activity.

- Use of carbon as a support for Pd promotes $\mathrm{O}_{2}$ desorption. Adsorbed $\mathrm{N}$ and $\mathrm{O}$ on carbon does not appear to participate in product formation.

The differences in the ability of the catalyst for manipulation of adsorbed oxygen resulting in different NO decomposition activities.

\section{Acknowledgment}

The authors gratefully acknowledge financial support for this research from the U.S. Department of Energy Grant DE-FG22-95PC955224. 


\section{References}

[1] M. Iwamoto, Future opportunities in Catalytic and Separation Technology, Studies in Surface science and Catalysis, Elsevier, Amsterdam-Oxford-New York-Tokyo, 1990.

[2] K. C. Taylor, Catal. Rev.-Sci. Eng. 35 (1993) 457.

[3] R.M. Heck, R.J. Farrauto, Catalytic Air Pollution Control, Commercial Technology, Van Nostrand Reinhold, 1995.

[4] R. Krishnamurthy, S. S. C. Chuang, and M. W. Balakos, J. Catal. 157 (1995) 512.

[5] B. J. Ku, J. K. Lee, D. Park, and H. Rhee, Ind. Eng. Chem. Res. 33 (1994) 2868.

[6] M. Shelef, Catal. Rev.-Sci. Eng. 95 (1995) 209.

[7] J.W. Hightower and D.A. Van Leirsburg, In The Catalytic Chemistry of Nitrogen Oxides; R.L. Klimisch, J.G. Larson, Eds.; Plenum Press, New York, p63 (1975).

[8] Y. Li and W.K. Hall, J. Catal, 129 (1991) 202.

[9] A. W. Aylor, S. C. Larsen J. A. Reimer and A. T. Bell, J. Catal. 157 (1995) 592.

[10] S.S.C. Chuang and C-D. Tan, J. Phys. Chem. B, 101(1997) 3000.

[11] Report on Basic Research Needs for Vehicles of the Future, P. M. Eisenberger (Editor), Princeton Materials Institute, Princeton University, 1995.

[12] E. Suuberg, H. Teng and J. Calo, Energy and Fuels, 6 (1992) 398.

[13] M.J. Illan-Gomez, A. Linares-Solano, L.R. Radovic and C. Salinas-Martinez de Lecea, Energy and Fuels, 10, 158, 1996.

[14] E. Ruckenstein and Y.H. Hu, Ind. Eng. Chem. Res., 36 (1997) 2533.

[15] T. Inui, T. Otowa, Y. Takegami, Ind. Eng. Chem. Prod. Res. Dev., 21 (1982) 56.

[16] S.S.C Chuang, M.A. Brundage, M.W. Balakos and G. Srinivas Appl. Spectrosc. 49 (1995) 1151.

[17] C.H. Rochester and B.J. Meldrum, J. Chem. Soc. Faraday Trans., 86 (1990) 3647.C.H.

[18] M.A. Vannice, R.T.K. Baker and A. Dandekar, 'submitted' Carbon, 1998.

[19] C. H. Rochester and B.J. Meldrum, J. Chem. Soc. Faraday Trans., 86 (1990) 1881.

[20] R. Krishnamurthy, M.S. Thesis, The University of Akron, 1998.

[21] R. Krishnamurthy and S. S. C. Chuang, J. Phys. Chem. 99 (1995) 16727.

[22] K. Almusaiteer and S. S. C. Chuang, 'in press' J. Catal. 
[23] S.H. Oh and J.E. Carpenter, J. Catal. 101 (1986) 114.

[24] R. D. Ramsier, Q. Gao, H.N: Walteburg, K.W. Lee, O.W. Nooij, L. Lefferts and J.T Yates Jr., Surf. Sci. 320 (1994) 209.

[25] M.A. Salas-Peregrin, M. Primet and H. Praliaud, Appl. Catal. B, 8 (1996) 79.

[26] A. T. Bell, Metal-Surface Reaction Energetics: Theory and Applications to Hetrogeneous catalysis, Chemisorption, and Surface Diffusion, E. Shustorovich (Editor), VCH, USA, 1991, Chap. 5, p191.

[27] A. de Koster and R. A. van Santen, J. Vac. Sci. Technol. A, 6 (1988) 1128. 
Approach

Catalytic reduction of NO with $\mathrm{CO}$ over three-way catalysts (Pt-Rh or Pd)

Selective catalytic reduction with $\mathrm{NH}_{3}$
Disadvantages

- Ineffective under net oxidizing conditions

- Sulfur poisoning

- High Pt and Rh metal costs

-Special handling and storage of $\mathrm{NH}_{3}$

- Special metering system to avoid $\mathrm{NH}_{3}$ slippage

- Very high capital costs

Selective catalytic reduction with Hydrocarbons

\section{Direct decomposition of NO}

- Perovskite type catalysts

- Cu-ZSM-5

- Pt/ $\mathrm{Al}_{2} \mathrm{O}_{3}$ based catalysts

- Tb- promoted catalysts
- Further improvement in the selectivity to $\mathrm{N}_{2}$ is needed. - Hydrocarbon slippage.

- Low activity and conversions of operation and susceptible to water and $\mathrm{SO}_{2}$ poisoning

- Low activity due to inability to desorb oxygen

- Loss of catalyst activity in the presence of $\mathrm{O}_{2}$.
- A narrow temperature window
- Simultaneous removal of $\mathrm{CO}, \mathrm{NO}$ and hydrocarbons

- High NO removal efficiency in the presence of $\mathrm{O}_{2}$.

- Potential for high NO removal efficiency in the presence of $\mathrm{O}_{2}$

- Chemical simplicity to form $\mathrm{N}_{2}$ and $\mathrm{O}_{2}$.

- Eliminating the use of reducing agents 
Table 2 Activity and Selectivity of the catalysts for NO decomposition at $673 \mathrm{~K}$

\begin{tabular}{|c|c|c|c|c|}
\hline & $\mathrm{Rh} / \mathrm{Al}_{2} \mathrm{O}_{3}$ & $\mathrm{Rh} / \mathrm{C}$ & $\mathrm{Pd} / \mathrm{Al}_{2} \mathrm{O}_{3}$ & $\mathrm{Pd} / \mathrm{C}$ \\
\hline $\begin{array}{l}\text { Amount of Oxygen adsorbed } \\
(\mu \mathrm{mol} / \mathrm{g})^{\mathrm{a}}\end{array}$ & 1303 & 1759 & 912 & 1800 \\
\hline $\begin{array}{l}\text { Number of Metal Surface atom } \\
(\mu \mathrm{mol} / \mathrm{g})^{b}\end{array}$ & 880.4 & 937.1 & 686.5 & 636.8 \\
\hline$W / F\left(\mathrm{~g} / \mathrm{cm}^{3} \cdot \mathrm{s}\right)$ & 0.25 & 0.3 & 0.29 & .0 .3 \\
\hline $\begin{array}{l}\text { Steady-state conversion } \\
\text { after break through (\%) }\end{array}$ & 14.0 & $100^{c}$ & 20.29 & 21.59 \\
\hline Yield of $\mathrm{O}_{2}(\%)^{d}$ & 0.4 & 0.0 & 1.74 & 1.4 \\
\hline Yield of $\mathrm{CO}_{2}(\%)$ & 0.0 & 22.6 & 0.0 & 0.0 \\
\hline $\begin{array}{l}\text { during stage } 1 \text { and } 2 \text { and normalized } \\
\text { b calculated from XRD data. } \\
\text { conversion during steady state form } \\
\text { d amount of } \mathrm{O}_{2} \text { produced/amount of } \mathrm{N}\end{array}$ & $\begin{array}{l}\text { asis. } \\
\mathrm{CO}_{2}\end{array}$ & & • & \\
\hline
\end{tabular}




\begin{tabular}{|c|c|c|c|c|c|}
\hline . & Reaction Steps & $\mathrm{Rh} / \mathrm{Al}_{2} \mathrm{O}_{3}$ & $\mathrm{Pd} / \mathrm{Al}_{2} \mathrm{O}_{3}$ & $\mathrm{Rh} / \mathrm{C}$ & $\mathrm{Pd} / \mathrm{C}$ \\
\hline Step 1 & $\mathrm{~S}^{0}+\mathrm{NO} \leftrightarrow \mathrm{S}^{0}-\mathrm{NO}^{-}$ & + & + & + & + \\
\hline Step 2 & $\mathrm{~S}^{0}-\mathrm{NO}^{-}+\mathrm{S}^{0} \rightarrow \mathrm{S}-\mathrm{N}+\mathrm{S}-\mathrm{O}\left(\mathrm{S}^{+}\right)$ & + & + & + & + \\
\hline Step 3 & $\mathrm{~S}-\mathrm{N}+\mathrm{S}-\mathrm{N} \rightarrow 2 \mathrm{~S}+\mathrm{N}_{2}$ & + & + & + & + \\
\hline Step 4 & $\mathrm{~S}^{+}+\mathrm{NO} \leftrightarrow \mathrm{S}^{+}-\mathrm{NO}$ & + & + & - & + \\
\hline Step 5 & $\mathrm{~S}-\mathrm{NO}+\mathrm{S}-\mathrm{N} \rightarrow 2 \mathrm{~S}+\mathrm{N}_{2} \mathrm{O}$ & + & + & + & + \\
\hline Step 6 & $\mathrm{~S}-\mathrm{O}+\mathrm{S}-\mathrm{O} \leftrightarrow 2 \mathrm{~S}+\mathrm{O}_{2}$ & + & + & - & + \\
\hline Step 7 & $\mathrm{~S}-\mathrm{NO}+\mathrm{S}-\mathrm{O} \rightarrow 2 \mathrm{~S}+\mathrm{NO}_{2}$ & + & + & - & - \\
\hline Step 8 & $\mathrm{~S}-\mathrm{O}+\mathrm{C} \rightarrow \mathrm{S}+\mathrm{C}+\mathrm{CO}_{2}$ & - & - & $\dot{+}$ & - \\
\hline Where & $\begin{array}{l}\mathrm{Rh}^{0} \text { or } \mathrm{Pd}^{0} \text { sites } \\
\text { dicates occurrence of the step } \\
\text { dicates absence of the step }\end{array}$ & & & & \\
\hline
\end{tabular}




\section{List of Figures}

Fig. 1 (a) MS analysis of $I R$ reactor effluent during the step switch from $\mathrm{He}\left(30 \mathrm{~cm}^{3} / \mathrm{min}\right)$ to $1 \%$ $\mathrm{NO}\left(30 \mathrm{~cm}^{3} / \mathrm{min}\right)$. (b) IR Intensity of adsorbates versus time, on $\mathrm{Rh} / \mathrm{Al}_{2} \mathrm{O}_{3}(125 \mathrm{mg})$ at $673 \mathrm{~K}$.

Fig. $2 \mathrm{IR}$ spectra of adsorbates during the step switch from $\mathrm{He}\left(30 \mathrm{~cm}^{3} / \mathrm{min}\right)$ to $1 \%$ NO (30 $\mathrm{cm}^{3} / \mathrm{min}$ ) on $\mathrm{Rh} / \mathrm{Al}_{2} \mathrm{O}_{3}$ at $673 \mathrm{~K}$.

Fig. 3 (a) MS analysis of $\mathbb{R}$ reactor effluent during the step switch from $\mathrm{He}\left(20 \mathrm{~cm}^{3} / \mathrm{min}\right)$ to $1 \%$ NO $\left(20 \mathrm{~cm}^{3} / \mathrm{min}\right)$. (b) IR Intensity of adsorbates versus time, on $\mathrm{Rh} / \mathrm{C}(100 \mathrm{mg})$ at $673 \mathrm{~K}$.

Fig. 4 IR spectra of adsorbates during the step switch from $\mathrm{He}\left(20 \mathrm{~cm}^{3} / \mathrm{min}\right)$ to $1 \%$ NO $(20$ $\mathrm{cm}^{3} / \mathrm{min}$ ) on $\mathrm{Rh} / \mathrm{C}$ at $673 \mathrm{~K}$.

Fig. 5 (a) MS analysis of $I R$ reactor effluent during the step switch from $\mathrm{He}\left(30 \mathrm{~cm}^{3} / \mathrm{min}\right)$ to $1 \%$ $\mathrm{NO}\left(30 \mathrm{~cm}^{3} / \mathrm{min}\right)$. (b) $\mathrm{RR}$ Intensity of adsorbates versus time, on $\mathrm{Pd} / \mathrm{Al}_{2} \mathrm{O}_{3}(125 \mathrm{mg})$ at $673 \mathrm{~K}$.

Fig. 6 IR spectra of adsorbates during the step switch from $\mathrm{He}\left(30 \mathrm{~cm}^{3} / \mathrm{min}\right)$ to $1 \%$ NO (30 $\mathrm{cm}^{3} / \mathrm{min}$ ) on $\mathrm{Pd} / \mathrm{Al}_{2} \mathrm{O}_{3}$ at $673 \mathrm{~K}$.

Fig. 7 (a) MS analysis of $\mathbb{R}$ reactor effluent during the step switch from $\mathrm{He}\left(20 \mathrm{~cm}^{3} / \mathrm{min}\right)$ to $1 \%$ NO $\left(20 \mathrm{~cm}^{3} / \mathrm{min}\right)$. (b) IR Intensity of adsorbates versus time, on $\mathrm{Pd} / \mathrm{C}(100 \mathrm{mg})$ at $673 \mathrm{~K}$.

Fig. 8 IR spectra of adsorbates during the step switch from $\mathrm{He}\left(20 \mathrm{~cm}^{3} / \mathrm{min}\right)$ to $1 \%$ NO (20 $\mathrm{cm}^{3} / \mathrm{min}$ ) on $\mathrm{Pd} / \mathrm{C}$ at $673 \mathrm{~K}$. 


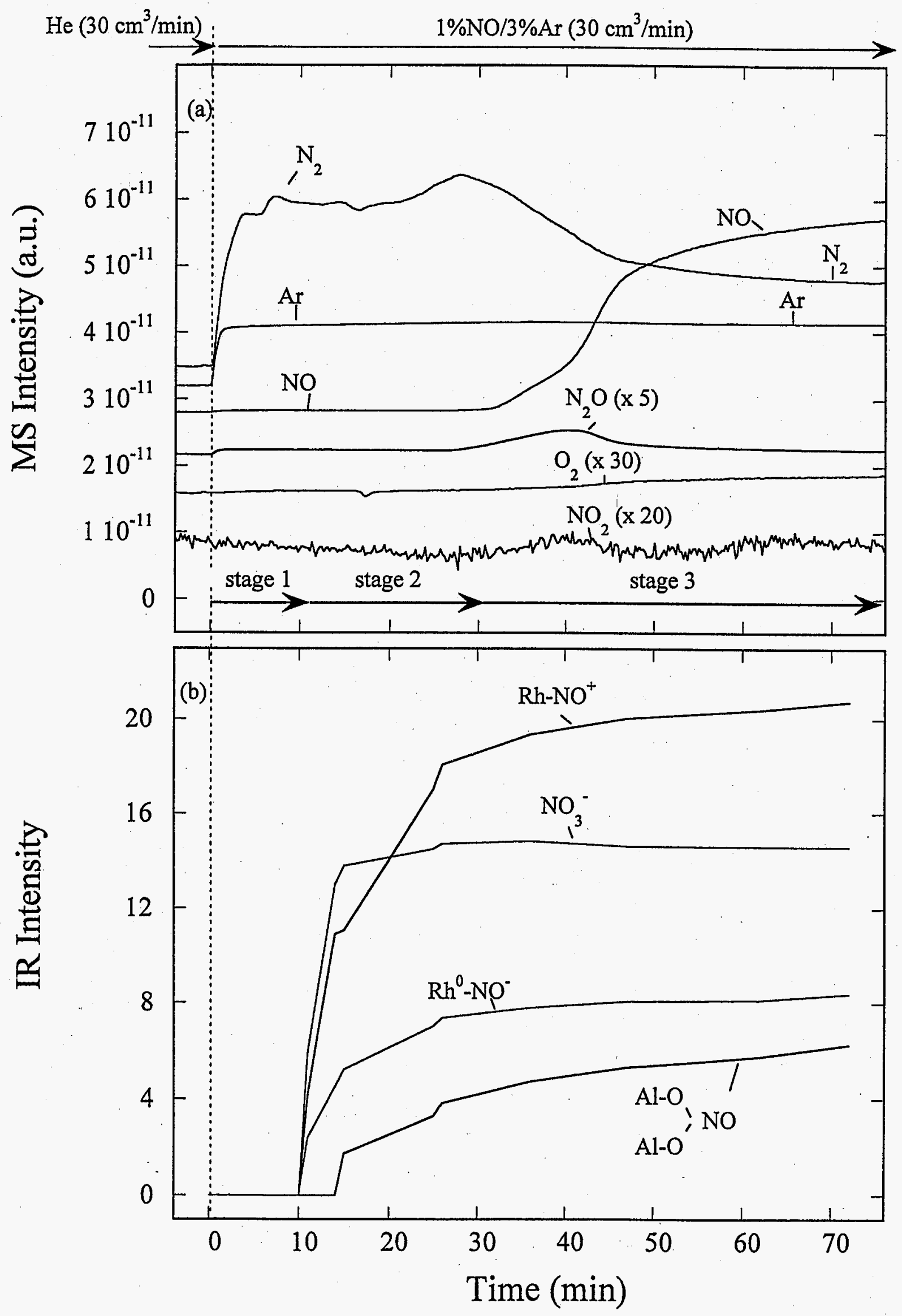

Fig. $1 \mathrm{a}$ and $\mathrm{b}$ 


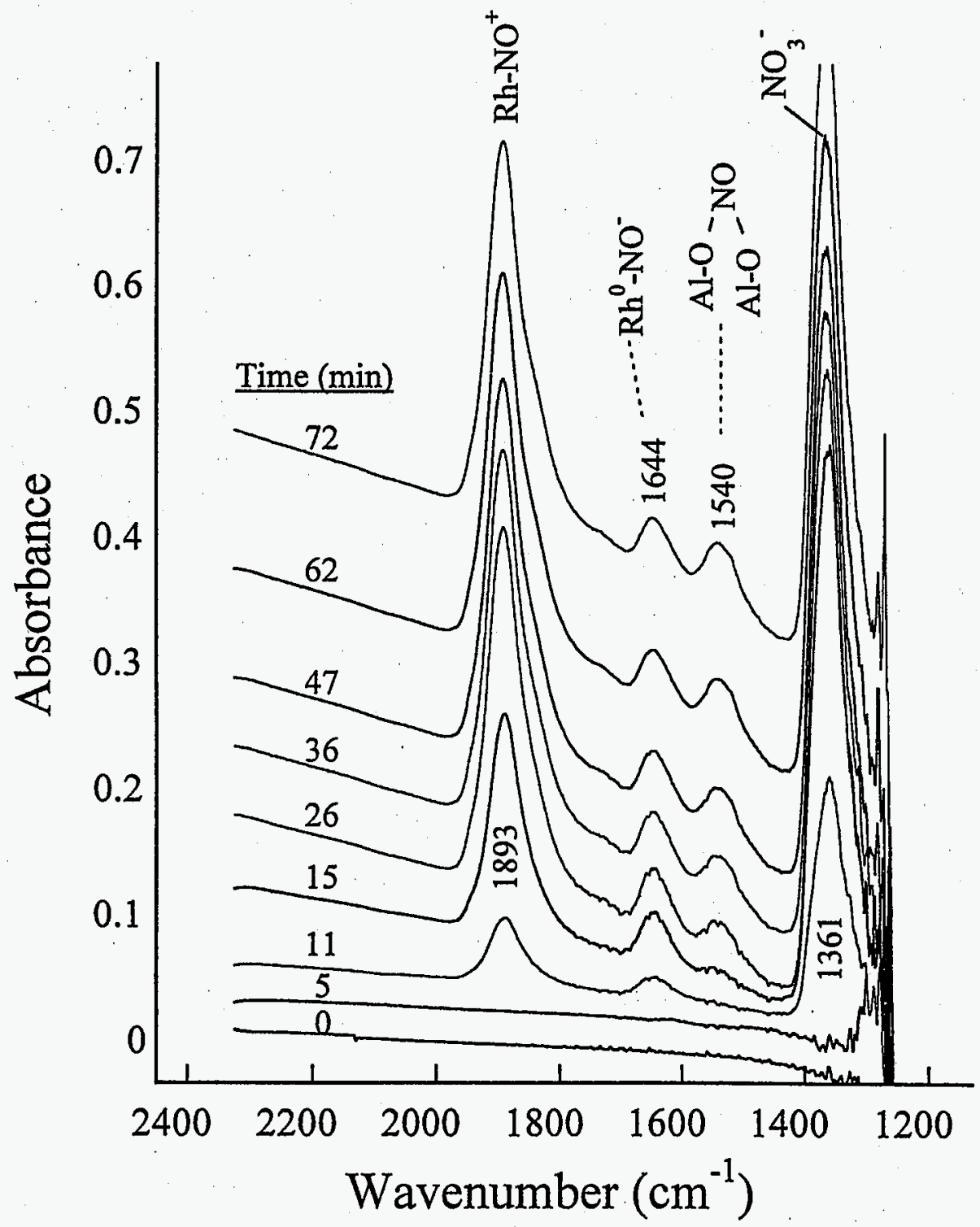

Fig. 2 


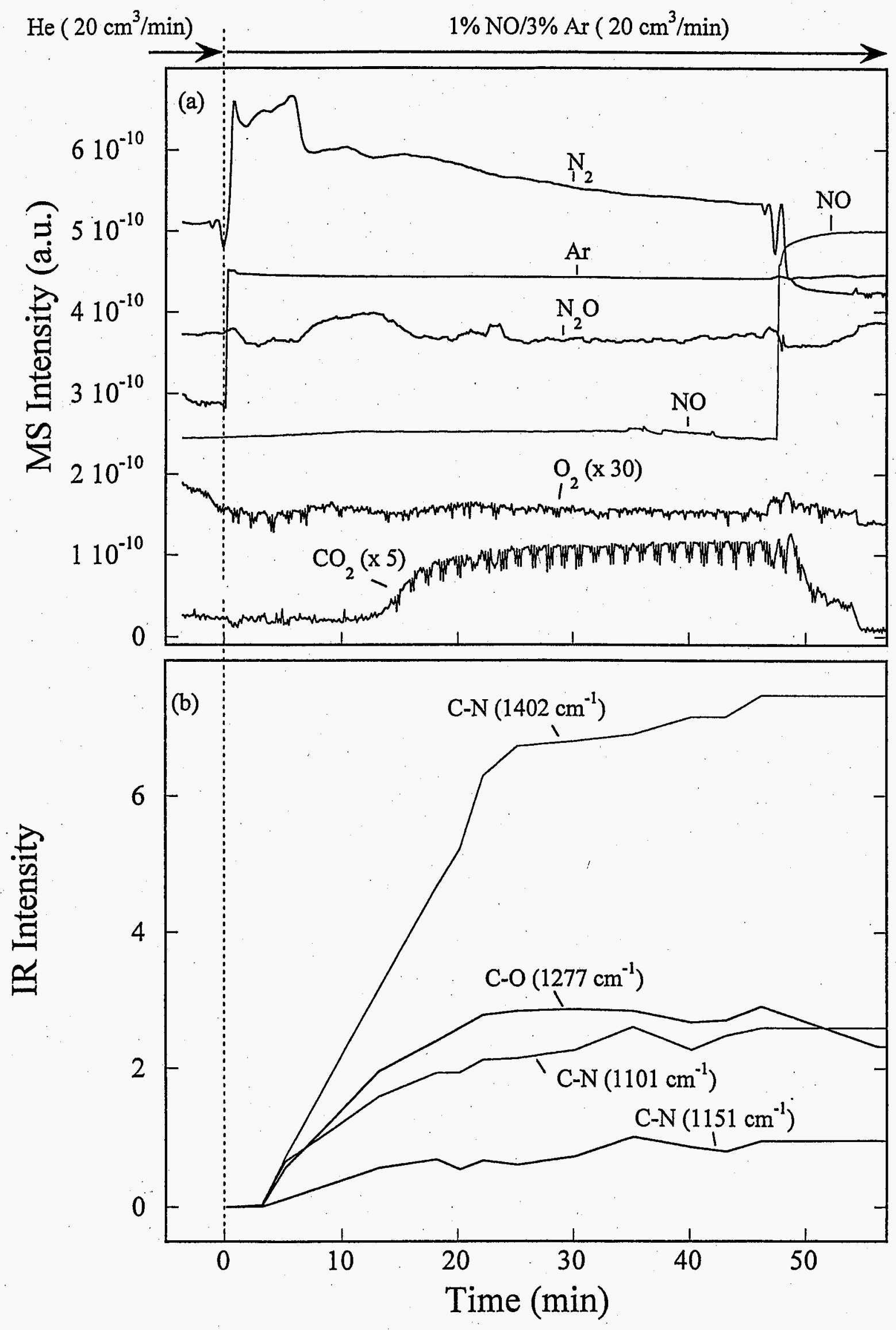

Fig. $3 a$ and $b$ 


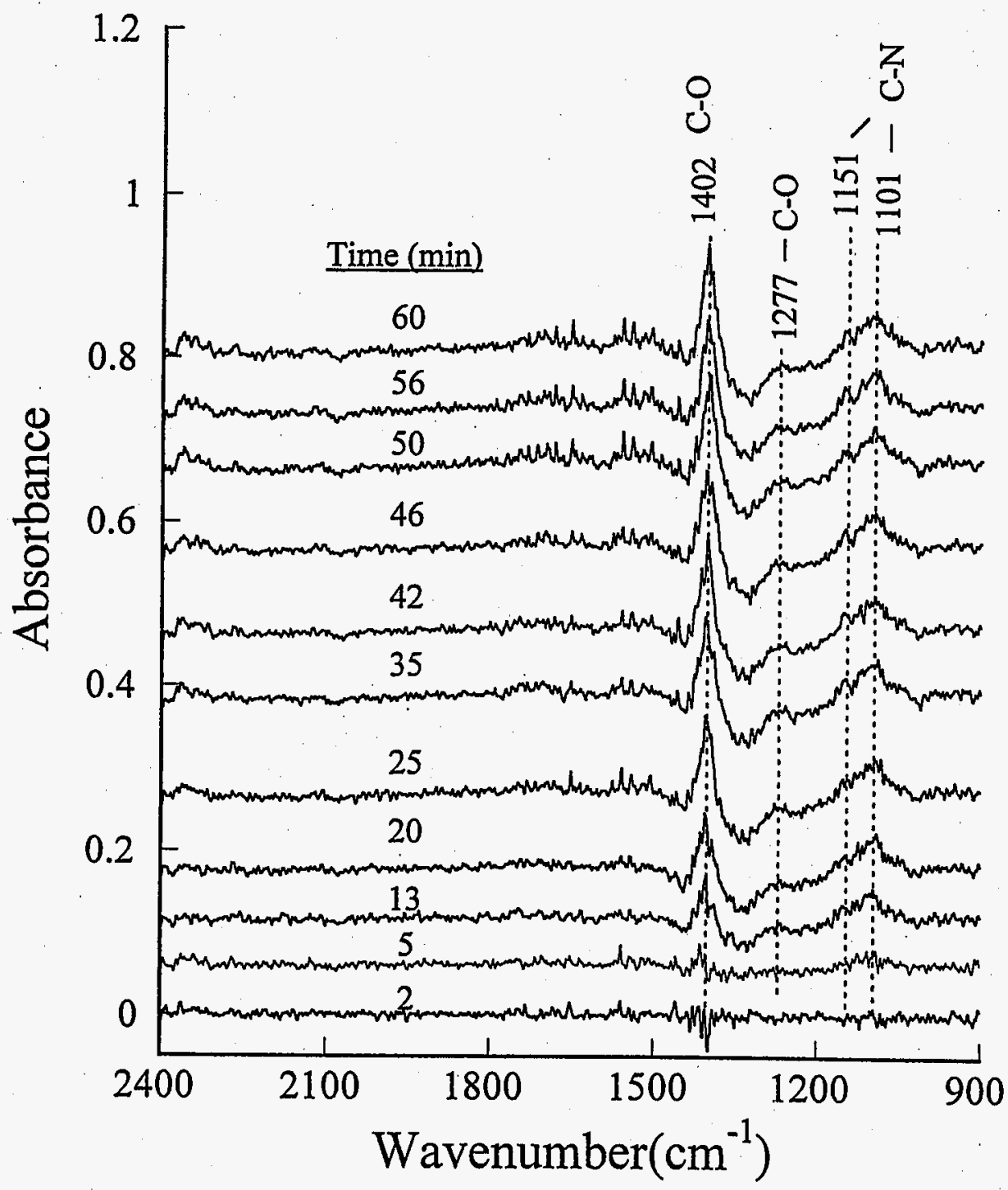

Fig. 4 


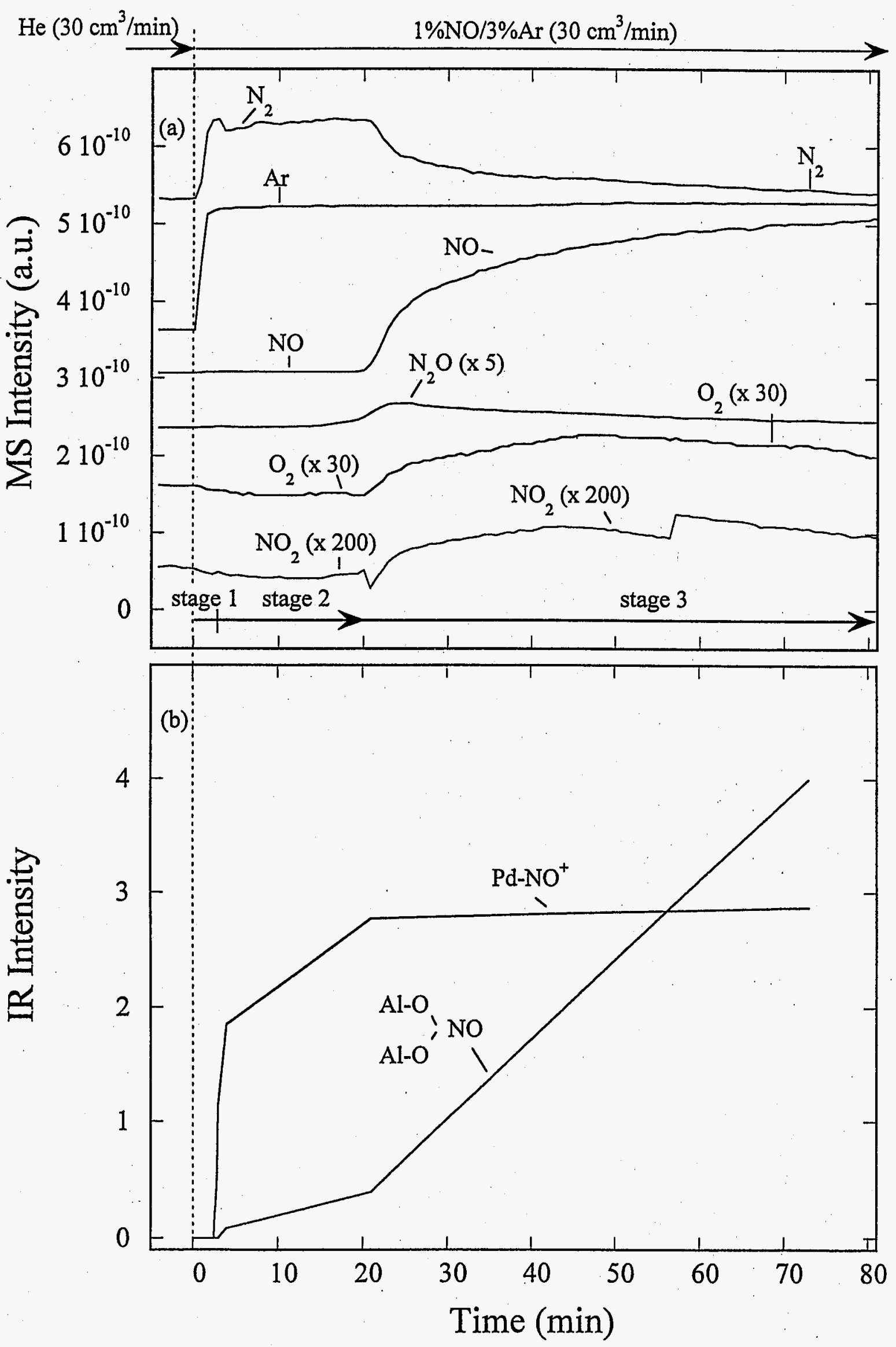

Fig. 5a and $b$ 


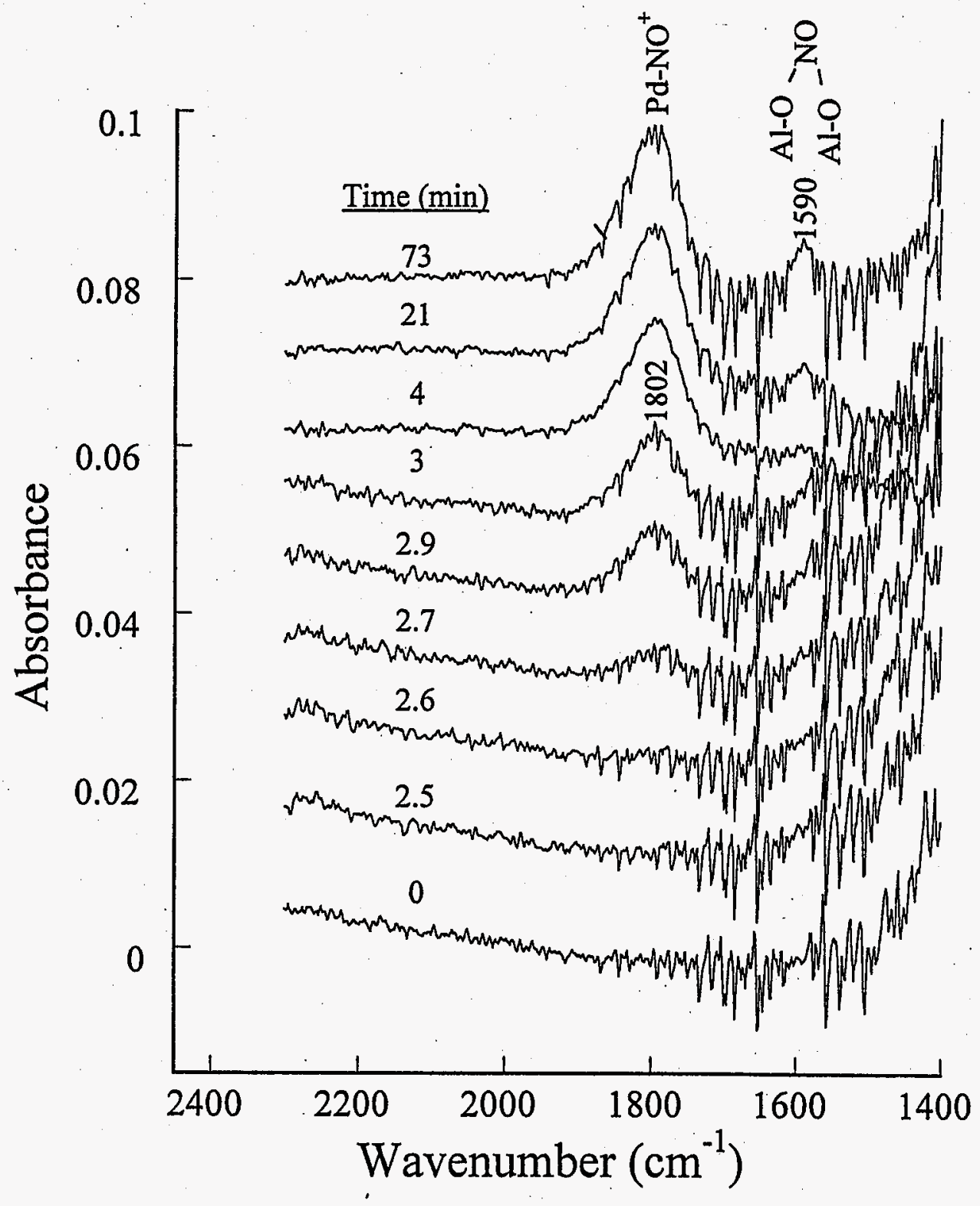

Fig. 6 


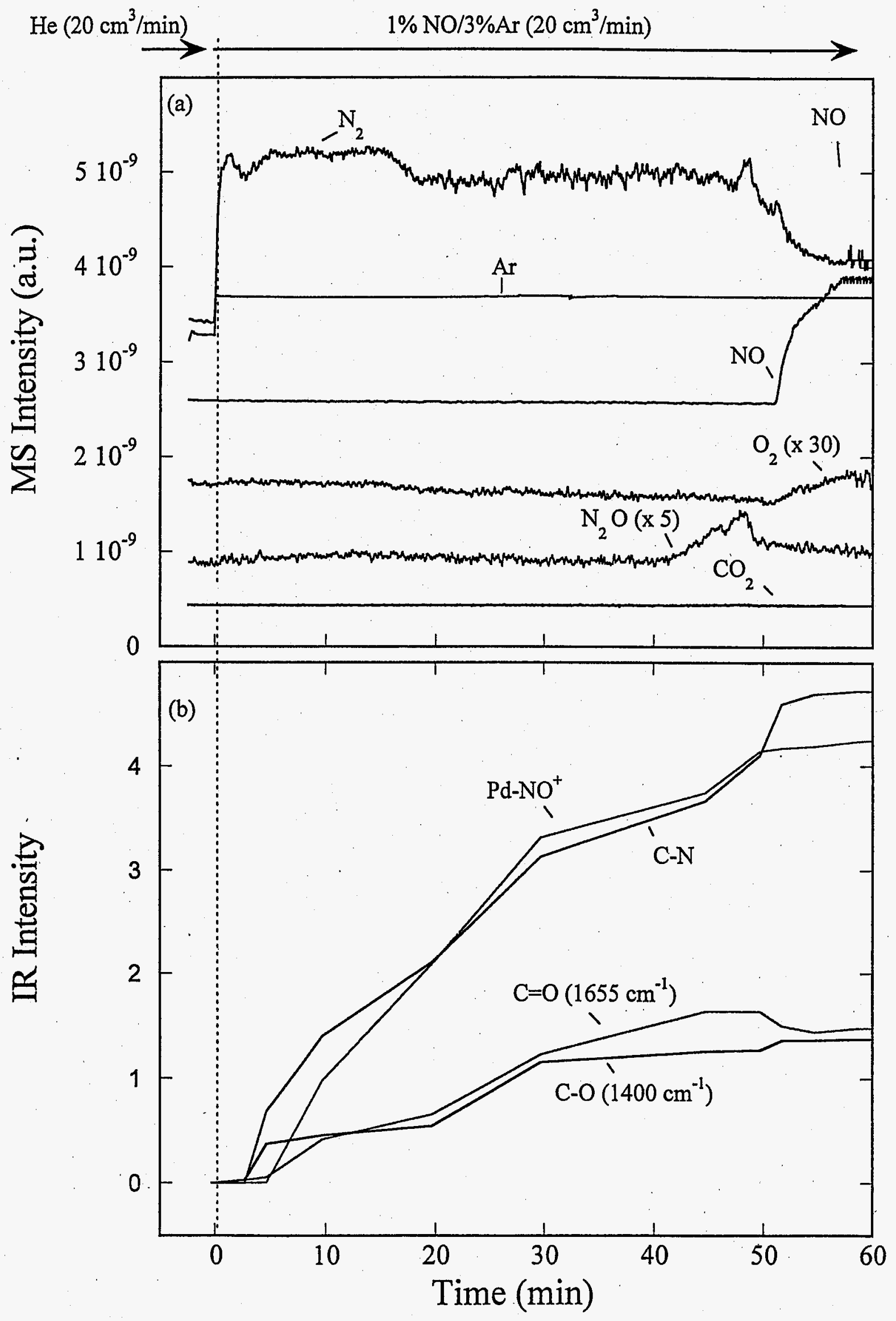

Fig. $7 \mathrm{a}$ and $\mathrm{b}$ 


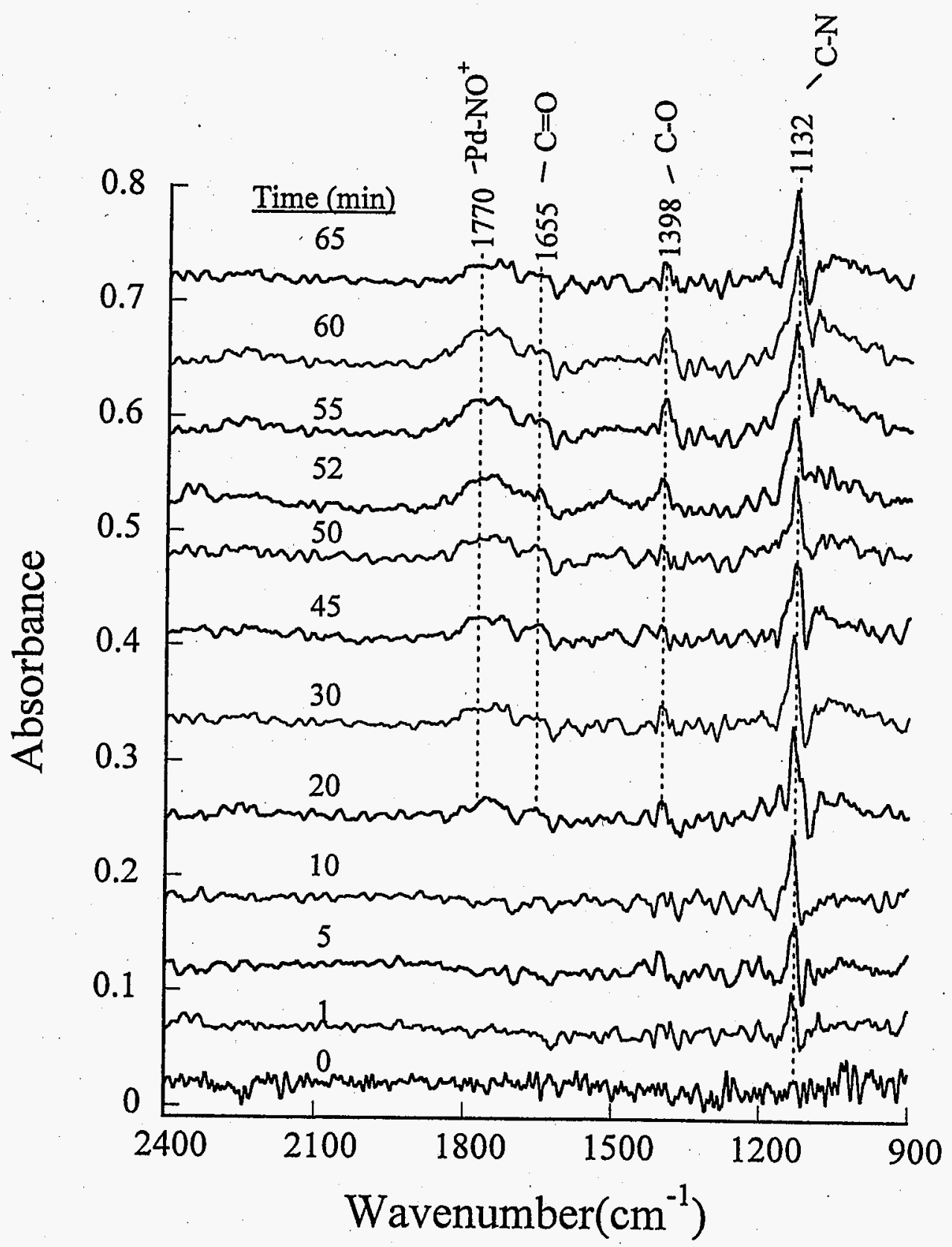

Fig. 8 


\section{Infrared and TPD Studies of Nitrates Adsorbed on $\mathrm{Tb}_{4} \mathrm{O}_{7}, \mathrm{La}_{2} \mathrm{O}_{3}, \mathrm{BaO}$, and $\mathrm{MgO} / \gamma-\mathrm{Al}_{2} \mathrm{O}_{3}$}

Yawu Chi and Steven S. C. Chuang*

Department of Chemical Engineering, The University of Akron, Akron OH 44325-3906

Abstract

$\mathrm{NO}$ and $\mathrm{O}_{2}$ coadsorption on $\gamma-\mathrm{Al}_{2} \mathrm{O}_{3}$-supported $\mathrm{Tb}_{4} \mathrm{O}_{7}, \mathrm{La}_{2} \mathrm{O}_{3}, \mathrm{BaO}$, and $\mathrm{MgO}$ has been investigated by in situ infrared spectroscopy coupled with temperature-programmed decomposition and desorption. $\mathrm{BaO} / \mathrm{Al}_{2} \mathrm{O}_{3}$ and $\mathrm{MgO} / \mathrm{Al}_{2} \mathrm{O}_{3}$ possess a higher $\mathrm{NO}_{x}$ storage capability than $\mathrm{Tb}_{4} \mathrm{O}_{7} / \mathrm{Al}_{2} \mathrm{O}_{3}$ and $\mathrm{La}_{2} \mathrm{O}_{3} / \mathrm{Al}_{2} \mathrm{O}_{3}$. $\mathrm{NO} / \mathrm{O}_{2}$ coadsorbed on $\mathrm{Tb}_{4} \mathrm{O}_{7}, \mathrm{La}_{2} \mathrm{O}_{3}$, and $\mathrm{BaO}$ in the form of bridging bidentate, chelating bidentate, and monodentate nitrates and on $\mathrm{MgO}$ in the form of bridging bidentate and monodentate nitrates via the reaction of adsorbed NO with adsorbed oxygen at $298 \mathrm{~K}$. NO/O $\mathrm{O}_{2}$ coadsorbed as a chelating bidentate nitrate on $\mathrm{Tb}_{4} \mathrm{O}_{7}$ and $\mathrm{La}_{2} \mathrm{O}_{3}$, and as a distinctive bridging bidentate nitrate on $\mathrm{BaO}$ and $\mathrm{MgO}$ via the reaction of adsorbed NO with surface lattice oxygen at $523 \mathrm{~K}$. These various forms of adsorbed nitrate differs in structure and reactivity from $\mathrm{Tb}\left(\mathrm{NO}_{3}\right)_{3}, \mathrm{La}\left(\mathrm{NO}_{3}\right)_{3}, \mathrm{Ba}\left(\mathrm{NO}_{3}\right)_{2}$, and $\mathrm{Mg}\left(\mathrm{NO}_{3}\right)_{2}$, the precursor used for preparation of metal oxides for $\mathrm{NO} / \mathrm{O}_{2}$ coadsorption. Temperatureprogrammed desorption (TPD) of chelating bidentate nitrate on $\mathrm{Tb}_{4} \mathrm{O}_{7}, \mathrm{La}_{2} \mathrm{O}_{3}$, and $\mathrm{BaO}$ produced primarily $\mathrm{NO}$ and $\mathrm{O}_{2}$ with maxima at 640 and $670 \mathrm{~K}$, respectively. TPD of bridging bidentate nitrate and monodentate nitrate on $\mathrm{Tb}_{4} \mathrm{O}_{7}, \mathrm{La}_{2} \mathrm{O}_{3}$, and $\mathrm{BaO}$ produced $\mathrm{NO}$ and $\mathrm{O}_{2}$ as major products and $\mathrm{N}_{2}$ and $\mathrm{N}_{2} \mathrm{O}$ as minor products at $320-500 \mathrm{~K}$. Decomposition of bridging bidentate on $\mathrm{MgO}$ produced $\mathrm{NO}$ as a major product and $\mathrm{N}_{2} \mathrm{O}$ as a minor product at a peak temperature of $690 \mathrm{~K}$. Peak temperatures for $\mathrm{Tb}\left(\mathrm{NO}_{3}\right)_{3}, \mathrm{La}\left(\mathrm{NO}_{3}\right)_{3}, \mathrm{Ba}\left(\mathrm{NO}_{3}\right)_{2}$, and $\mathrm{Mg}\left(\mathrm{NO}_{3}\right)_{2}$ decomposition

\footnotetext{
"To whom all correspondence should be addressed; Email: schuang@uakron.edu; Tel: (330) 972-6993; Fax: (330) 972-5856.
} 
occurred between those for bridging and chelating nitrates. The difference in stability of chelating and bridging bidentate nitrates on various metal oxides may provide a wide range of operating temperature for $\mathrm{NO}_{\mathbf{x}}$ storage.

\section{Introduction}

The control of NO emission to meet increasingly stringent standards has been a major challenge for coal-fired power plants and automobile industries. No catalysts for NO removal in an oxidizing environment are found to have activities close to being practical. Catalytic approaches for the removal of NO include [i] the reaction of NO with CO over Rh-Pt and Pdbased catalysts in the catalytic converter, ${ }^{1,2}$ [ii] the reaction of NO and CO on metal oxides, ${ }^{3,4}$ [iii] the reaction of NO with hydrocarbons on $\mathrm{Cu}-$ and $\mathrm{Co}-\mathrm{ZSM}-5^{5-9}$ and alkali-MgO catalysts, ${ }^{10-12}$ [iv] the selective catalytic reduction (SCR) of NO with $\mathrm{NH}_{3},{ }^{13,14}$ and [v] the direct decomposition of NO over $\mathrm{Cu}-,{ }^{15-19} \mathrm{~Tb}-,{ }^{20}$-and Ba-based ${ }^{10-12,21-25}$ catalysts.

All of these catalytic approaches involve (i) N-O bond dissociation of adsorbed NO or precursor containing NO to form adsorbed nitrogen and adsorbed oxygen, (ii) combination of adsorbed nitrogen itself or with other $\mathrm{N}$-containing species to form gaseous nitrogen, (iii) reaction of adsorbed oxygen with reducing agents such as $\mathrm{CO}, \mathrm{NH}_{3}$, and hydrocarbons, and/or (iv) desorption of oxygen. Removal of adsorbed oxygen is required to complete the catalytic cycle of NO reduction. The direct decomposition of NO to nitrogen $\left(\mathrm{N}_{2}\right)$ and oxygen $\left(\mathrm{O}_{2}\right)$ appears to be an attractive approach; however, it suffers from poisoning by the presence of excess oxygen. $\mathrm{No} \mathrm{NO}_{x}$ (i.e. $\mathrm{NO}$ and $\mathrm{NO}_{2}$ ) removal catalysts for diesel/lean-burn engines are known to have activities close to being practical. Although the use of reducing agents effectively removes adsorbed oxygen, it complicates the NO removal process. In addition, it has limited the range of operating conditions, resulting in high capital and operating costs. The limiting 
operating temperature range is a result of the interaction of competing reactions: NO reduction and reductant oxidation. To avoid the direct oxidation of reductant, the concept of NO storage and reduction has been tested for removal of $\mathrm{NO}$ in an oxidizing environment. $\mathrm{BaO}-\mathrm{CuO},{ }^{21}$ $\mathrm{Pt} / \mathrm{Ba} / \mathrm{Al}_{2} \mathrm{O}_{3},{ }^{22}$ binary oxides (Ba- $\mathrm{Cu}, \mathrm{Mn}-\mathrm{Y}$, and $\left.\mathrm{Mn}-\mathrm{Zr}\right){ }^{23} \mathrm{Pt}-\mathrm{Ba} /$ washcoat, ${ }^{24}$ and $\mathrm{Cu}$-exchanged mordenite $e^{25}$ have been tested for $\mathrm{NO}_{\mathrm{x}}$ storage. A better understanding of $\mathrm{NO} / \mathrm{O}_{2}$ interaction with the $\mathrm{NO}_{\mathrm{x}}$ storage medium is needed to move from the empirical material screening toward rational design.

The objective of this study is to investigate the adsorption of $\mathrm{NO} / \mathrm{O}_{2}$ on metal oxides and decomposition of their adsorbates. $\mathrm{Tb}^{20,26} \mathrm{La}^{27-30} \mathrm{Ba}^{10-12,24,31,32}$ and $\mathrm{Mg}^{10-12,32-34}$ oxides are selected for this study due to their wide uses as promoters and storage mediums in automobile and lean burn NO removal catalysts. This paper reports the results of an infrared study of (i) $\mathrm{NO}_{\mathrm{x}}$ storage on metal oxides in an oxidizing environment and (ii) desorption behavior of adsorbed $\mathrm{NO}_{\mathrm{x}}$ on metal oxides.

\section{Experimental}

\subsection{Preparation of $\gamma-\mathrm{Al}_{2} \mathrm{O}_{3}$-supported Nitrates and Infrared (IR) Characterization} $\gamma-\mathrm{Al}_{2} \mathrm{O}_{3}$-supported $\mathrm{Tb}\left(\mathrm{NO}_{3}\right)_{3}, \mathrm{La}\left(\mathrm{NO}_{3}\right)_{3}, \mathrm{Ba}\left(\mathrm{NO}_{3}\right)_{2}$, and $\mathrm{Mg}\left(\mathrm{NO}_{3}\right)_{2}$ (Alfa products) were prepared by incipient wetness impregnation of $\gamma-\mathrm{Al}_{2} \mathrm{O}_{3}$ (Alfa products, surface area: $100 \mathrm{~m} / \mathrm{g}$, pore size: $0.01-0.02 \mu \mathrm{m}$ ) with a metal nitrate solution. The ratio of the volume of the solution to the weight of $\gamma-\mathrm{Al}_{2} \mathrm{O}_{3}$ was about $1 \mathrm{~cm}^{3}$ to $2 \mathrm{~g}$. The impregnated samples were dried overnight in air at room temperature. The loading of nitrate on $\gamma-\mathrm{Al}_{2} \mathrm{O}_{3}$ is listed in Table 1.

The original metal nitrates and $\gamma-\mathrm{Al}_{2} \mathrm{O}_{3}$-supported nitrates (i.e. nitrates $/ \gamma-\mathrm{Al}_{2} \mathrm{O}_{3}$ ) were mixed with $\mathrm{KBr}$ (Alfa products, $\mathrm{KBr}$ spectrograde, ultrapure) at a weight sample/ $\mathrm{KBr}$ ratio of 1 : 
100 and pressed into self-supporting disks for infrared characterization at $298 \mathrm{~K}$. The sample was mixed with $\mathrm{KBr}$ to obtain high resolution of nitrate bands. The infrared (IR) spectra of $\mathrm{Tb}\left(\mathrm{NO}_{3}\right)_{3} \cdot 6 \mathrm{H}_{2} \mathrm{O}, \mathrm{La}\left(\mathrm{NO}_{3}\right)_{3} \cdot 6 \mathrm{H}_{2} \mathrm{O}, \mathrm{Ba}\left(\mathrm{NO}_{3}\right)_{2}$, and $\mathrm{Mg}\left(\mathrm{NO}_{3}\right)_{2} \cdot 6 \mathrm{H}_{2} \mathrm{O}$ were obtained by subtracting the $\mathrm{KBr}$ spectrum from each specific nitrate $/ \mathrm{KBr}$ spectrum; the IR spectra of $\mathrm{Tb}\left(\mathrm{NO}_{3}\right)_{3} \cdot \mathrm{H}_{2} \mathrm{O} / \mathrm{Al}_{2} \mathrm{O}_{3}, \mathrm{La}\left(\mathrm{NO}_{3}\right)_{3} \cdot \mathrm{H}_{2} \mathrm{O} / \mathrm{Al}_{2} \mathrm{O}_{3}, \mathrm{Ba}\left(\mathrm{NO}_{3}\right)_{2} \cdot \mathrm{H}_{2} \mathrm{O} / \mathrm{Al}_{2} \mathrm{O}_{3}$, and $\mathrm{Mg}\left(\mathrm{NO}_{3}\right)_{2} \cdot \mathrm{H}_{2} \mathrm{O} / \mathrm{Al}_{2} \mathrm{O}_{3}$ was obtained by subtracting the $\mathrm{Al}_{2} \mathrm{O}_{3} / \mathrm{KBr}$ spectrum from each specific nitrate $/ \mathrm{Al}_{2} \mathrm{O}_{3} / \mathrm{KBr}$ spectrum.

\subsection{Adsorption and Decomposition/Desorption studies}

Figure 1 illustrates the experimental approach and sequence for study of each metal nitrate/ $\gamma-\mathrm{Al}_{2} \mathrm{O}_{3}$. The experimental system consists of (i) the gas flow system with a 4-port switching valve and mass flow controllers for $\mathrm{NO}, \mathrm{O}_{2}$, and $\mathrm{He}$, (ii) the in situ IR reactor cell with self-supporting catalyst disks, and (iii) the analysis section with a Nicolet magna-IR 550 spectrometer for recording IR spectra of adsorbed species and Balzers QMG 112 quadruple mass spectrometer (MS) for the analysis of reactant and product flows. The gaseous responses for $\mathrm{He}$ at $\mathrm{m} / \mathrm{e}=4, \mathrm{~N}_{2}$ at $\mathrm{m} / \mathrm{e}=28, \mathrm{NO}$ at $\mathrm{m} / \mathrm{e}=30, \mathrm{O}_{2}$ at $m / e=32, \mathrm{~N}_{2} \mathrm{O}$ at $\mathrm{m} / \mathrm{e}=44$, and $\mathrm{NO}_{2}$ at $m / e=46$ were monitored by the MS. Contribution of $\mathrm{N}_{2} \mathrm{O}$ and $\mathrm{NO}_{2}$ to fragments at $\mathrm{m} / \mathrm{e}=30$ can be resolved from relative intensities of fragments and parent ions of the calibrated $\mathrm{N}_{2} \mathrm{O}$ and $\mathrm{NO}_{2}$ pulse responses.

To avoid complication from $\mathrm{NO}_{\mathrm{x}}$ adsorption on $\mathrm{KBr}, 30 \mathrm{mg}$ of fresh nitrate $/ \gamma-\mathrm{Al}_{2} \mathrm{O}_{3}$ powder was pressed into a self-supporting disk without mixing with $\mathrm{KBr}$ and placed in the infrared beam path inside the infrared cell for temperature-programmed decomposition, $\mathrm{NO} / \mathrm{O}_{2}$ adsorption, and temperature-programmed desorption studies. ${ }^{35}$ Additional nitrate disks with a 
total of $70 \mathrm{mg}$ were broken into flakes and placed in the vicinity of the catalyst disk to increase the quantity of decomposed products in the reactor effluent, allowing accurate analysis of their compositions.

Metal nitrates $/ \gamma-\mathrm{Al}_{2} \mathrm{O}_{3}$ underwent a series of studies: (a) temperature programmed decomposition (TPDE) studies from 298 to $773 \mathrm{~K}$ at a heating rate of $10 \mathrm{~K} / \mathrm{min}$ in flowing helium at $75 \mathrm{~cm}^{3} / \mathrm{min}$, (b) adsorption of $\mathrm{NO} / \mathrm{O}_{2}$ at $298 \mathrm{~K}$ over metal oxide $/ \mathrm{Al}_{2} \mathrm{O}_{3}$ produced from TPDE, (c) temperature-programmed desorption (TPD) study of $\mathrm{NO} / \mathrm{O}_{2}$ adsorbates from 298 to $773 \mathrm{~K}$ at a heating rate of $10 \mathrm{~K} / \mathrm{min}$ in flowing helium at $75 \mathrm{~cm}^{3} / \mathrm{min}$, (d) adsorption of $\mathrm{NO} / \mathrm{O}_{2}$ at $523 \mathrm{~K}$ over metal oxide/ $\mathrm{Al}_{2} \mathrm{O}_{3}$, and (e) TPD of $\mathrm{NO} / \mathrm{O}_{2}$ adsorbates from 523 to $773 \mathrm{~K}$. Fig. 1 (a)(c) show the typical IR spectra of nitrates as well as MS profiles of gaseous species obtained during TPDE of $\mathrm{Tb}\left(\mathrm{NO}_{3}\right)_{3}$ on $\mathrm{Al}_{2} \mathrm{O}_{3}, \mathrm{NO} / \mathrm{O}_{2}$ adsorption on $\mathrm{Tb}_{4} \mathrm{O}_{7} / \mathrm{Al}_{2} \mathrm{O}_{3}$, and TPD studies. The metal oxides produced from TPDE of nitrates $/ \gamma-\mathrm{Al}_{2} \mathrm{O}_{3}$ were characterized by $\mathrm{X}$-ray diffraction (XRD) using Philips Analytical, XRD B. V. diffractometer with $\mathrm{Cu}-\mathrm{K}_{\alpha}$ radiation.

\section{Results}

\subsection{IR Characterization of Metal Nitrates and Metal Nitrates $/ \gamma-\mathrm{Al}_{2} \mathrm{O}_{3}$}

Figures $2 \mathrm{a}$ and $\mathrm{b}$ compare the IR spectra of metal nitrates and metal nitrates $/ \gamma-\mathrm{Al}_{2} \mathrm{O}_{3}$ at $298 \mathrm{~K}$. All of nitrates used in this study exhibit typical nitrate bands at around $1380 \mathrm{~cm}^{-1}\left(\mathrm{NO}_{2}\right.$ stretching, $\gamma_{3}$ ), $1037 \mathrm{~cm}^{-1}$ (NO stretching, $\gamma_{1}$ ), 814-826 $\mathrm{cm}^{-1}$ (out of plane bending, $\gamma_{2}$ ), 729-750 $\mathrm{cm}^{-1}\left(\mathrm{NO}_{2}\right.$ bending, $\left.\gamma_{4}\right)$, and 1764-1778 $\mathrm{cm}^{-1}\left(\gamma_{1}+\gamma_{4}\right)^{36-45}$ IR spectra of $\mathrm{Tb}\left(\mathrm{NO}_{3}\right)_{3} \cdot 5 \mathrm{H}_{2} \mathrm{O}$, $\mathrm{La}\left(\mathrm{NO}_{3}\right)_{3} \cdot 6 \mathrm{H}_{2} \mathrm{O}, \mathrm{Ba}\left(\mathrm{NO}_{3}\right)_{2}$, and $\mathrm{Mg}\left(\mathrm{NO}_{3}\right)_{2} \cdot 6 \mathrm{H}_{2} \mathrm{O}$ observed here agree well with those reported in literature. ${ }^{36,39}$ The bands at 3375 and $1640 \mathrm{~cm}^{-1}$ for $\mathrm{Tb}\left(\mathrm{NO}_{3}\right)_{3} \cdot 5 \mathrm{H}_{2} \mathrm{O}, \mathrm{La}\left(\mathrm{NO}_{3}\right)_{3} \cdot 6 \mathrm{H}_{2} \mathrm{O}$, and $\mathrm{Mg}\left(\mathrm{NO}_{3}\right)_{2} \cdot 6 \mathrm{H}_{2} \mathrm{O}$ can be attributed to $\mathrm{H}_{2} \mathrm{O}$. The absence of bands at around 3400 and $1630 \mathrm{~cm}^{-1}$ 
for anhydrous $\mathrm{Ba}\left(\mathrm{NO}_{3}\right)_{2}$ further confirm the $\mathrm{H}_{2} \mathrm{O}$ assignment. $\mathrm{Tb}\left(\mathrm{NO}_{3}\right)_{3} \cdot 5 \mathrm{H}_{2} \mathrm{O}$ and $\mathrm{La}\left(\mathrm{NO}_{3}\right)_{3} \cdot 6 \mathrm{H}_{2} \mathrm{O}$, the lanthanide elements, exhibit the triplet in the $1290-1480 \mathrm{~cm}^{-1}$ region.

The $\gamma-\mathrm{Al}_{2} \mathrm{O}_{3}$ surface has a greater effect on $\mathrm{Tb}$ and La nitrates than on $\mathrm{Ba}$ and $\mathrm{Mg}$ nitrates. Fig. $2 \mathrm{~b}$ shows that the contour and wavenumber of infrared bands for $\mathrm{Ba}$ and $\mathrm{Mg}$ nitrates are modified by the $\mathrm{Al}_{2} \mathrm{O}_{3}$ support probably due to the overlapping IR absorption of $\mathrm{Al}_{2} \mathrm{O}_{3}$ and distortion of the nitrate structure induced by the $\mathrm{Al}_{2} \mathrm{O}_{3}$ surface. In contrast, the triplet characteristics of free nitrate in the $1296-1475 \mathrm{~cm}^{-1}$ region decreased their intensities and chelating nitrates at $1505-1580 \mathrm{~cm}^{-1}$ emerged on $\mathrm{La}$ and $\mathrm{Tb}$ nitrates on $\mathrm{Al}_{2} \mathrm{O}_{3}$. It is interesting to observe that the nitrates of the elements in the same group exhibit a similar vibration frequency, indicating the similarity in their structures.

\subsection{XRD Determination}

Figure 3 shows the XRD patterns of metal oxides $/ \gamma-\mathrm{Al}_{2} \mathrm{O}_{3}$ produced from the thermal decomposition of nitrates $/ \gamma-\mathrm{Al}_{2} \mathrm{O}_{3}$. Tb and $\mathrm{Ba}$ oxides gave distinct $\mathrm{X}$-ray diffraction patterns for $\mathrm{Tb}_{4} \mathrm{O}_{7}$ and $\mathrm{BaO}$ whose crystallite sizes were determined to be 117.2 and $220.8 \AA$, respectively, by the Scherrer equation. ${ }^{46}$ The absence of XRD patterns for $\mathrm{La}$ and $\mathrm{Mg}$ oxides suggests that these oxides were highly dispersed on $\mathrm{Al}_{2} \mathrm{O}_{3}$ with a crystallite size less than $30 \AA$. These oxides produced from nitrate decomposition were denoted as $\mathrm{Tb}_{4} \mathrm{O}_{7} / \mathrm{Al}_{2} \mathrm{O}_{3}, \mathrm{La}_{2} \mathrm{O}_{3} / \mathrm{Al}_{2} \mathrm{O}_{3}, \mathrm{BaO} / \mathrm{Al}_{2} \mathrm{O}_{3}$. and $\mathrm{MgO} / \mathrm{Al}_{2} \mathrm{O}_{3}$ in this study since they are the most abundant forms of oxides on $\mathrm{Al}_{2} \mathrm{O}_{3}$ as evidenced by XRD. Table 1 lists the loading of metal nitrates, metal oxides, and the weight percentage needed for achieving a monolayer dispersion ${ }^{47}$ of each metal oxide on $\gamma-\mathrm{Al}_{2} \mathrm{O}_{3}$. Loading of $\mathrm{Tb}_{4} \mathrm{O}_{7}, \mathrm{La}_{2} \mathrm{O}_{3}$ and $\mathrm{BaO}$ is sufficiently high to achieve more than two layers of oxides 
on the surface of $\mathrm{Al}_{2} \mathrm{O}_{3}$. XRD results indicate that $\mathrm{Tb}_{4} \mathrm{O}_{7}$ and $\mathrm{BaO}$ aggregated on the surface as particles.

\subsection{Adsorption of $\mathrm{NO}$ and $\mathrm{O}_{2}$ on Metal Oxides $/ \mathrm{Al}_{2} \mathrm{O}_{3}$}

Figure 4 shows the MS profiles of the reactor effluent and in situ IR spectra of adsorbates produced from flowing $0.08 \% \mathrm{NO} / 2 \% \mathrm{O}_{2}$ in $\mathrm{He}$ over $\mathrm{Tb}_{4} \mathrm{O}_{7} / \mathrm{Al}_{2} \mathrm{O}_{3}$ at $298 \mathrm{~K}$ (Fig. $4 \mathrm{a}$ and b) and $523 \mathrm{~K}$ (Fig. $4 \mathrm{c}$ and d), respectively. $\mathrm{NO} / \mathrm{O}_{2}$ flow was introduced into the reactor by a step-switch from He flow to $\mathrm{NO} / \mathrm{O}_{2} / \mathrm{He}$ flow. The use of a well-defined step switch allows observation of adsorbate evolution and accurate determination of the amount of NO adsorbed. The amount of NO adsorbed at 298 and $523 \mathrm{~K}$ corresponds to the shaded area in Fig. $4 \mathrm{a}$ and c, respectively. Table 2 lists the amount of $\mathrm{NO}$ adsorbed at 298 and $523 \mathrm{~K}$ on $\mathrm{Tb}_{4} \mathrm{O}_{7} / \mathrm{Al}_{2} \mathrm{O}_{3}$ and other oxides used in this study. Exposure of $\mathrm{Tb}_{4} \mathrm{O}_{7} / \mathrm{Al}_{2} \mathrm{O}_{3}$ to $\mathrm{NO} / \mathrm{O}_{2} / \mathrm{He}$ flow at $298 \mathrm{~K}$ produced (i) $\mathrm{N}_{2} \mathrm{O}$ and $\mathrm{N}_{2}$ as shown by the increase in $\mathrm{N}_{2} \mathrm{O}$ and $\mathrm{N}_{2} \mathrm{MS}$ profiles in Fig. $4 a$ and (ii)_bridging bidentate-nitrate $\left(\begin{array}{l}\mathrm{Tb}-\mathrm{O} \\ \mathrm{Tb}-\mathrm{O}\end{array}>\mathrm{N}-\mathrm{O}\right)$ at $1630 \mathrm{~cm}^{-1}$, chelating bidentate nitrate $\left(\mathrm{Tb}<{ }_{\mathrm{O}}^{\mathrm{O}}>\mathrm{N}-\mathrm{O}\right)$ at $1570 \mathrm{~cm}^{-1}$ with their asymmetric $\mathrm{NO}_{2}$ stretching overlap at around $1298 \mathrm{~cm}^{-1}$, monodentate nitrate $(\mathrm{Tb}-\mathrm{O}-\mathrm{N}<\mathrm{O}$ ) at $1470 \mathrm{~cm}^{-1}, \mathrm{NO}_{3}^{-}$at $1380 \mathrm{~cm}^{-1}, 4,45$ and $\mathrm{Tb}-\mathrm{NO}^{+}$at $1928 \mathrm{~cm}^{-1}$. It should be noted that the broad IR band in the region of $1380-1630 \mathrm{~cm}^{-1}$, which is the result of multiple overlapping bands, could not be unambiguously determined due to the ill-defined catalyst surface. Band assignment here follows the reported classical works, ${ }^{44,45}$ previous literature ${ }^{16-34,36-43}$, and IR spectra of nitrates and nitrates $/ \mathrm{Al}_{2} \mathrm{O}_{3}$ in Fig. 2. The low intensity of the bands in the $1300-1450 \mathrm{~cm}^{-1}$ region for $\mathrm{NO}_{3}^{-}$ indicates that $\mathrm{Tb}\left(\mathrm{NO}_{3}\right)_{3}$ was not reconstructed on $\mathrm{Tb}_{4} \mathrm{O}_{7} / \mathrm{Al}_{2} \mathrm{O}_{3}$. Flowing $\mathrm{NO} / \mathrm{O}_{2}$ at $523 \mathrm{~K}$ produced (i) more $\mathrm{N}_{2}$ but less $\mathrm{N}_{2} \mathrm{O}$ than that at $298 \mathrm{~K}$ and (ii) a dominant $\mathrm{Tb}<{ }_{\mathrm{O}}^{\mathrm{O}}>\mathrm{N}-\mathrm{O}$ at 1556 
and $1282 \mathrm{~cm}^{-1}$. NO approached steady state faster at $523 \mathrm{~K}$ than at $298 \mathrm{~K}$. The lack of Tb-NO+ at $523 \mathrm{~K}$ may be due to the oxidization of adsorbed $\mathrm{NO}^{+}$to $\mathrm{Tb}<\mathrm{O}_{\mathrm{O}}^{\mathrm{O}}>\mathrm{N}-\mathrm{O}$.

Figure 5 compares the in situ IR spectra of adsorbates produced from flowing $\mathrm{NO} / \mathrm{O}_{2}$ over $\mathrm{La}_{2} \mathrm{O}_{3} / \mathrm{Al}_{2} \mathrm{O}_{3}, \mathrm{BaO} / \mathrm{Al}_{2} \mathrm{O}_{3}$, and $\mathrm{MgO} / \mathrm{Al}_{2} \mathrm{O}_{3}$ at 298 and $523 \mathrm{~K}$. Band assignment of these various adsorbates are summarized in Table 3. In general, bridging bidentate nitrate $\left(\begin{array}{l}\mathrm{M}-\mathrm{O} \\ \mathrm{M}-\mathrm{O}\end{array}\right.$ exhibits an NO vibration band at $1600-1650 \mathrm{~cm}^{-1}$ and a weak $\mathrm{NO}_{2}$ asymmetric vibration band at $1170-1225 \mathrm{~cm}^{-1}$. Chelating bidentate nitrate $\left(\mathrm{M}<{ }_{\mathrm{O}}^{\mathrm{O}}>\mathrm{N}-\mathrm{O}\right)$ gives an NO vibration band at 1500 $1565 \mathrm{~cm}^{-1}$ and a weak $\mathrm{NO}_{2}$ asymmetric vibration band at $1260-1300 \mathrm{~cm}^{-1}$. Monodentate nitrate $\left(\mathrm{M}-\mathrm{O}-\mathrm{N}<\mathrm{O}\right.$ ) shows an $\mathrm{NO}_{2}$ asymmetric vibration band at $1480-1530 \mathrm{~cm}^{-1}$ and a weak $\mathrm{NO}_{2}$ symmetric vibration band at $1250-1290 \mathrm{~cm}^{-1}$. Nitrate $\left(\mathrm{NO}_{3}{ }^{-}\right)$displays an $\mathrm{NO}_{2}$ stretching band at around $1380 \mathrm{~cm}^{-1} \cdot 44,45$ IR spectra of adsorbates produced from La oxide resemble those on $\mathrm{Tb}$ oxide in spite of the significant difference in their crystallite size and difference in the stoichiometry of $\mathrm{Tb}_{4} \mathrm{O}_{7}$ and $\mathrm{La}_{2} \mathrm{O}_{3}$ (i.e., the possible form of $\mathrm{La}$ oxide). Adsorbed nitrates on $\mathrm{BaO}$ and $\mathrm{MgO}$ show distinct bridging bidentate nitrate bands at $1630 \mathrm{~cm}^{-1}$ and $\mathrm{N}_{2} \mathrm{O}_{2}{ }^{2-}$ on $\mathrm{MgO}$ at 1748 and $1257 \mathrm{~cm}^{-1} \cdot 3^{34,48}$ The formation of bridging bidentate nitrate on $\mathrm{MgO}$ is significantly faster than the monodentate nitrate at $298 \mathrm{~K}$. The $\mathrm{IR}$ intensity corresponds to the concentration . of adsorbates, also reflecting the number of specific adsorption sites for these adsorbates. However, a lack of extinction coefficients for these various forms of adsorbed $\mathrm{NO}_{\mathrm{x}}$ species does not allow use of these adsorbate intensities to determine the number of adsorption sites. 


\subsection{TPDE and TPD studies}

Figure 6 compares the normalized product MS profiles during TPDE of $\mathrm{Tb}\left(\mathrm{NO}_{3}\right)_{3}$ on $\mathrm{Al}_{2} \mathrm{O}_{3}$ (Fig. 6a) to those during TPD of adsorbates on $\mathrm{Tb}_{4} \mathrm{O}_{7} / \mathrm{Al}_{2} \mathrm{O}_{3}$ from 298 to 773 (Fig. 6b) and from 523 to $773 \mathrm{~K}$ (Fig. 6c) in He flow. These adsorbates were produced from $\mathrm{NO} / \mathrm{O}_{2}$ adsorption at $298 \mathrm{~K}$ and $523 \mathrm{~K}$, respectively. $\mathrm{Tb}\left(\mathrm{NO}_{3}\right)_{3}$ began to decompose at $374 \mathrm{~K}$, releasing $\mathrm{NO}, \mathrm{O}_{2}, \mathrm{~N}_{2} \mathrm{O}, \mathrm{N}_{2}$, and $\mathrm{NO}_{2}$ with a total amount of $185.5 \mu \mathrm{mol}$, an $\mathrm{N} / \mathrm{O}$ ratio of 1.1 , and an $\mathrm{NO} / \mathrm{O}_{2}$ ratio of 12.5. The MS intensity profiles were normalized with the calibration factors of each species so that the shaded area under the MS profiles corresponds to the product amount. Table 4 lists the amount of products produced from TPDE of $\gamma-\mathrm{Al}_{2} \mathrm{O}_{3}$-supported nitrates and TPD of adsorbates on metal oxides. Since NO is the dominant product, the ratio of $\mathrm{N}$ to $\mathrm{O}$ for all the products is near 1 , indicating that decomposition of nitrates leaves oxygen on the metal oxide surface.

Figure 7 shows the in situ IR spectra of adsorbed $\mathrm{NO}_{\mathrm{x}}$ on $\mathrm{Tb}_{4} \mathrm{O}_{7} / \mathrm{Al}_{2} \mathrm{O}_{3}$ taken during TPD from 298 to $773 \mathrm{~K}$ and from 523 to $773 \mathrm{~K}$ as well as the IR spectra of $\mathrm{Tb}\left(\mathrm{NO}_{3}\right)_{3} \cdot 5 \mathrm{H}_{2} \mathrm{O}$ and $\mathrm{Tb}\left(\mathrm{NO}_{3}\right)_{3} \cdot \mathrm{H}_{2} \mathrm{O} / \mathrm{Al}_{2} \mathrm{O}_{3}$. The IR bands below $1200 \mathrm{~cm}^{-1}$ for nitrates $/ \mathrm{Al}_{2} \mathrm{O}_{3}$ and adsorbed $\mathrm{NO}_{\mathrm{x}}$ on metal oxides $/ \mathrm{Al}_{2} \mathrm{O}_{3}$ were blocked by the $\mathrm{Al}_{2} \mathrm{O}_{3}$ support and $\mathrm{CaF}_{2}$ windows. Decrease in $\mathrm{IR}$ intensity with increasing temperature is indicative of desorption/decomposition of adsorbates on $\mathrm{Tb}_{4} \mathrm{O}_{7} / \mathrm{Al}_{2} \mathrm{O}_{3}$, suggesting that these adsorbates are responsible for the formation of $\mathrm{NO}, \mathrm{O}_{2}, \mathrm{~N}_{2} \mathrm{O}$, $\mathrm{N}_{2}$, and $\mathrm{NO}_{2}$. The decrease in chelating bidentate nitrate, which was produced from $\mathrm{NO} / \mathrm{O}_{2}$ adsorption at $523 \mathrm{~K}$ in Fig. 7, corresponds to a symmetric $\mathrm{NO}, \mathrm{O}_{2}$, and $\mathrm{N}_{2}$ desorption profile with the N/O molar ratio of 0.8 centered at $640 \mathrm{~K}$ in Fig $6 \mathrm{c}$, indicating the conversion of this nitrate to $\mathrm{NO}$ and $\mathrm{O}_{2}$. The small amount of desorbed $\mathrm{O}_{2}$ suggests that the chelating bidentate nitrate 
decomposed primarily to NO, leaving $\mathrm{O}_{2}$ on the metal oxide surface. The NO desorption centered at $640 \mathrm{~K}$ in Fig. 6c has also been observed for NO TPD from 298 to $773 \mathrm{~K}$ in Fig. $6 \mathrm{~b}$. The NO desorption at $640 \mathrm{~K}$ in Fig. $6 \mathrm{~b}$ is indeed a result of decomposition of chelating bidentate nitrate at $1556 \mathrm{~cm}^{-1}$ as shown in Fig 7. The most interesting observations in Figs. 6 and 7 are that (i) $\mathrm{N}_{2}$ was produced as a minor product and (ii) the amount of $\mathrm{NO}, \mathrm{O}_{2}, \mathrm{~N}_{2}$ and $\mathrm{N}_{2} \mathrm{O}$ desorbed from nitrates adsorbed on $\mathrm{Tb}_{4} \mathrm{O}_{7} / \gamma-\mathrm{Al}_{2} \mathrm{O}_{3}$ is significantly less than the decomposition of the original nitrate. It appears that metal oxide produced from $\mathrm{Tb}\left(\mathrm{NO}_{3}\right)_{3}$ decomposition has agglomerated and decreased the number of surface metal cations available for adsorption. Furthermore, each $\mathrm{Tb}$ in $\mathrm{Tb}\left(\mathrm{NO}_{3}\right)_{3}$ accommodates three $\left(\mathrm{NO}_{3}\right)^{-;}$while each $\mathrm{Tb}$ in bridging and chelating bidentate nitrates and monodentate nitrate can accommodate only one $\left(\mathrm{NO}_{3}\right)$.

Figures 8 and 9 show the product MS profiles and IR spectra during TPDE of $\mathrm{La}\left(\mathrm{NO}_{3}\right)_{3} \cdot \mathrm{H}_{2} \mathrm{O} / \mathrm{Al}_{2} \mathrm{O}_{3}$ and subsequent TPD studies on $\mathrm{La}_{2} \mathrm{O}_{3} / \mathrm{Al}_{2} \mathrm{O}_{3}$. TPDE of $\mathrm{La}\left(\mathrm{NO}_{3}\right)_{3} \cdot \mathrm{H}_{2} \mathrm{O} / \mathrm{Al}_{2} \mathrm{O}_{3}$ exhibited similar IR and MS patterns to that of $\mathrm{Tb}\left(\mathrm{NO}_{3}\right)_{3} \cdot \mathrm{H}_{2} \mathrm{O} / \mathrm{Al}_{2} \mathrm{O}_{3} \cdot \mathrm{N}_{2}$ formation on $\mathrm{La}_{2} \mathrm{O}_{3} / \mathrm{Al}_{2} \mathrm{O}_{3}$ is less than that on $\mathrm{Tb}_{4} \mathrm{O}_{7} / \mathrm{Al}_{2} \mathrm{O}_{3}$.

Figures 10 and 11 show the MS profiles and IR spectra during TPDE of $\mathrm{Ba}\left(\mathrm{NO}_{3}\right)_{2} \cdot \mathrm{H}_{2} \mathrm{O} / \mathrm{Al}_{2} \mathrm{O}_{3}$ and subsequent TPD studies on $\mathrm{BaO} / \mathrm{Al}_{2} \mathrm{O}_{3}$. TPDE of $\mathrm{Ba}\left(\mathrm{NO}_{3}\right)_{2}$ on $\mathrm{Al}_{2} \mathrm{O}_{3}$ exhibited different MS profile patterns from those for $\mathrm{Tb}\left(\mathrm{NO}_{3}\right)_{3}$ and $\mathrm{La}\left(\mathrm{NO}_{3}\right)_{3}$ with only one $\mathrm{O}_{2}$ desorption peak at $725 \mathrm{~K}$.

Although $\mathrm{Ba}\left(\mathrm{NO}_{3}\right)_{2} / \mathrm{Al}_{2} \mathrm{O}_{3}$ and $\mathrm{Mg}\left(\mathrm{NO}_{3}\right)_{2} / \mathrm{Al}_{2} \mathrm{O}_{3}$ exhibit similar IR spectra as shown in Fig. 2, their TPDE and TPD/RR profiles show dramatic differences, as shown in Figs. 10-13. The major difference is the absence of $\mathrm{O}_{2}$ during the TPDE of $\mathrm{Mg}\left(\mathrm{NO}_{3}\right)_{2}$ and the TPD of $\mathrm{NO} / \mathrm{O}_{2}$ adsorbates on $\mathrm{MgO} / \mathrm{Al}_{2} \mathrm{O}_{3}$. The latter is due to the lack of $\mathrm{O}_{2}$ adsorption during $\mathrm{NO} / \mathrm{O}_{2}$ 
adsorption at 298 and $523 \mathrm{~K}$. In addition, bridging bidentate nitrate is centered at $1630 \mathrm{~cm}^{-1}$ on $\mathrm{MgO}$ and at $1600 \mathrm{~cm}^{-1}$ on $\mathrm{BaO}$ at $523 \mathrm{~K}$. The former decomposed to $\mathrm{NO}$ and $\mathrm{N}_{2} \mathrm{O}$ while the latter decomposed to $\mathrm{NO}$ and $\mathrm{O}_{2}$, reflecting their differences in structure and reactivity.

\section{Discussion}

\subsection{Formation of Adsorbed Nitrate}

Adsorption of $\mathrm{NO}$ and $\mathrm{O}_{2}$ on $\mathrm{Tb}_{4} \mathrm{O}_{7}, \mathrm{La}_{2} \mathrm{O}_{3}, \mathrm{BaO}$, and $\mathrm{MgO}$ proceeds through a different pathway and pattern from that on noble metals. NO adsorbs on the reduced noble metal through the $\mathrm{N}$ atom in the form of $\mathrm{M}^{0}-\mathrm{NO}$ (where $\mathrm{M}^{0}$ is the reduced metal site). ${ }^{49-52}$ NO stands either perpendicularly or titled to the surface; depending on the nature of the surface sites. Coadsorption of NO and $\mathrm{O}_{2}$ usually leads to the formation of $\mathrm{M}^{+}-\mathrm{NO}$ where $\mathrm{M}^{+}$is formed by oxidation of $\mathrm{M}^{0} . \mathrm{M}^{+}-\mathrm{NO}$ has often been denoted as $\mathrm{M}-\mathrm{NO}^{+}{ }^{+49-52}$ Interestingly, this type of $\mathrm{M}$ $\mathrm{NO}^{+}$has been observed on $\mathrm{Tb}_{4} \mathrm{O}_{7}$ and $\mathrm{La}_{2} \mathrm{O}_{3}$. The presence of $\mathrm{M}-\mathrm{NO}^{+}$on $\mathrm{Tb}_{4} \mathrm{O}_{7}$ and $\mathrm{La}_{2} \mathrm{O}_{3}$ could be due to the non-stoichiometric nature of $\mathrm{Tb}$ and $\mathrm{La}$ oxides where their cations are exposed for direct NO adsorption.

Due to ill-defined states of the surfaces of these oxides, the elementary steps involved in the formation of nitrates from $\mathrm{NO} / \mathrm{O}_{2}$ adsorption is significantly more difficult to elucidate than those on noble metals. $\mathrm{NO} / \mathrm{O}_{2}$ coadsorption on these oxides produced three types of nitrates: bridging bidentate, chelating bidentate, and monodentate nitrates. In addition, a trace amount of $\mathrm{N}_{2}$ and $\mathrm{N}_{2} \mathrm{O}$ were produced, indicating the occurrence of $\mathrm{N}-\mathrm{O}$ bond dissociation and $\mathrm{N}-\mathrm{N}$ bond formation. These two steps occurred to a very limited extent on the oxide surface as evidenced by low product formation rates. $\mathrm{N}-\mathrm{O}$ bond dissociation is expected to occur on the unsaturated coordination sites where there are deficiencies in oxygen coordination. ${ }^{53-56} \mathrm{~N}-\mathrm{N}$ bond formation, a facile process, could be immediately followed by $\mathrm{N}-\mathrm{O}$ dissociation. Coadsorption of $\mathrm{NO}$ and 
$\mathrm{O}_{2}$ allows $\mathrm{O}_{2}$ to compete for unsaturated coordination sites, further decreasing the $\mathrm{N}_{2}$ and $\mathrm{N}_{2} \mathrm{O}$ formation.

$\mathrm{O}_{2}$ may adsorb on the oxide surface according to the following sequence: $:^{57-59}$

$$
\left.\mathrm{O}_{2}(\mathrm{~g}) \Leftrightarrow \mathrm{O}_{2}(\text { ads. }) \stackrel{+e}{\Leftrightarrow} \mathrm{O}_{2}^{-} \text {(ads. }\right) \stackrel{+e}{\Leftrightarrow} \mathrm{O}_{2}^{2-}(\text { ads. }) \Leftrightarrow 2 \mathrm{O}^{-}(\text {ads. }) \stackrel{+2 e}{\Leftrightarrow} 2 \mathrm{O}^{2-} \text { (lattice) }
$$

Electron spin resonance (ESR) studies of adsorbed oxygen on $\mathrm{TiO}_{2}, \mathrm{ZnO}, \mathrm{Fe}_{2} \mathrm{O}_{3}, \mathrm{MgO}$, and $\mathrm{NiO}$ provide evidence to support $\mathrm{O}_{2}^{-}$formation..$^{57-58,60-63}$ This type of oxygen is stable at 298 K. Increasing temperature causes transformation of $\mathrm{O}_{2}{ }^{-}$to $\mathrm{O}^{2 \cdot}$ (i.e., lattice oxygen) ${ }^{58,60,63-65}$ Thus, which types of adsorbed oxygen predominate may depend on the type and state of the surface and temperature. The metal cation may serve as an electron donor, allowing electron transfer to oxygen and increasing the oxidation state of the cation. ${ }^{64}$ The non-stoichiometric metal oxides such as $\mathrm{Tb}_{4} \mathrm{O}_{7}$ and those oxides with redox properties may allow oxidation of their cations.

Formation of bridging bidentate nitrate, chelating bidentate nitrate, and monodentate nitrate from $\mathrm{NO}$ and $\mathrm{O}_{2}$ adsorption on $\mathrm{Tb}_{4} \mathrm{O}_{7}, \mathrm{La}_{2} \mathrm{O}_{3}$, and $\mathrm{BaO}$ may involve different forms of adsorbed oxygen which serve as a Lewis base site. The overall reaction may be written as:

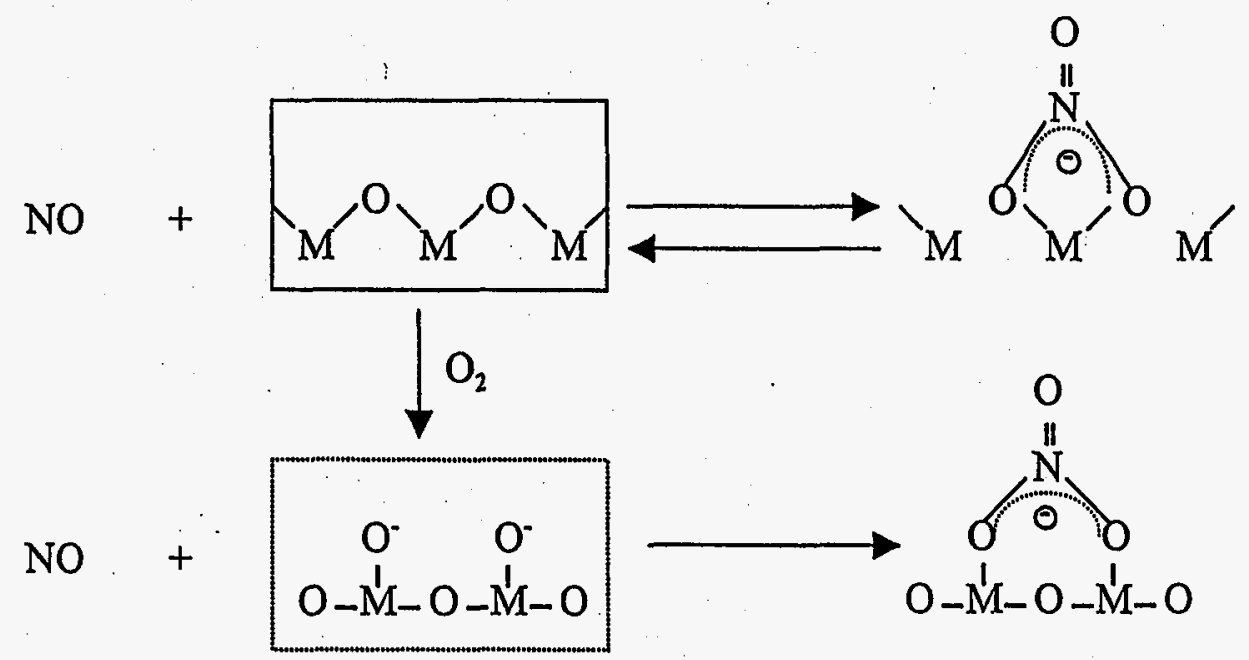


The formation of chelating bidentate nitrate has been observed on NO adsorption on $\mathrm{Tb}_{4} \mathrm{O}_{7}{ }^{66}$ Results in Fig. 4 shows that coadsorption of $\mathrm{NO}$ and $\mathrm{O}_{2}$ on $\mathrm{Tb}_{4} \mathrm{O}_{7}$ produced both bridging and chelating bidentate nitrates at $298 \mathrm{~K}$ and formed only chelating bidentate nitrate at $523 \mathrm{~K}$. Similar observations have been reported on oxidized chromia. ${ }^{67}$ The N-O single bond in chelating bidentate nitrate appears to come from the lattice oxygen of the oxide while the oxygen in bridging bidentate nitrate could result from adsorbed oxygen. The adsorbed oxygen may be in the form of $\mathrm{O}^{-}$which locates in a configuration favoring the bridging bidentate nitrate formation. This proposed scheme explains the formation of a dominant chelating bidentate band at $523 \mathrm{~K}$ and the formation of bridging bidentate nitrate at $298 \mathrm{~K}$ where significantly more $\mathrm{O}_{2}$ is adsorbed than at $523 \mathrm{~K}$ shown in Table 2. The absence of adsorbed nitro species and $\mathrm{NO}_{2}$ in the product stream indicates either the lack of surface sites available for the $\mathrm{NO}+\mathrm{O}^{-}$reaction or the rapid conversion of nitro/ $\mathrm{NO}_{2}$ species to nitrates.

Pre-transition metal oxides such as $\mathrm{MgO}$ are very inert and can neither be oxidized nor reduced easily. ${ }^{64,68}$ It is indeed not surprising to observe the low $\mathrm{O}_{2}$ adsorption capability on MgO. Although $\mathrm{MgO}$ lacks $\mathrm{O}_{2}$ adsorption capability, gaseous $\mathrm{O}_{2}$ can exchange with $\mathrm{O}$ on the solid surface..$^{55}$ The bridging bidentate nitrate could be formed from NO adsorption coupled with oxygen exchange.

$\mathrm{BaO}$ and $\mathrm{MgO}$, the alkali earth elements, show distinct differences in their TPDE and TPD/IR profiles. $\mathrm{BaO}$ is known for its exceptional capability for $\mathrm{NO}_{\mathbf{x}}$ storage. ${ }^{24,31}$ Results in Fig. 5 show that $\mathrm{NO}$ and $\mathrm{O}_{2}$ coadsorb on $\mathrm{BaO}$ as bridging bidentate, chelating bidentate, and monodentate nitrates at 298 and $523 \mathrm{~K}$. Lunsford and coworkers ${ }^{10-12}$ reported that flowing NO alone over defect-rich $\mathrm{BaO} / \mathrm{MgO}$ produced nitrates, nitrites, and $\mathrm{Ba}$-nitro complexes; exposure of nitrite/nitro species to oxygen led to the formation of $\mathrm{NO}_{3}^{-}$; exposure of $\mathrm{BaO}_{2}$ to $\mathrm{NO}$ produced 
nitro and $\mathrm{NO}_{3}:$ Our recent study ${ }^{69}$ on $\mathrm{CuO} / \mathrm{Al}_{2} \mathrm{O}_{3}$ showed that the successive oxidation of adsorbed nitrite and nitro species produced various forms of nitrate during $\mathrm{NO} / \mathrm{O}_{2}$ coadsorption. All of these studies reveals that nitrate is the final form of the products on the oxide surface regardless of sequence of $\mathrm{NO} / \mathrm{O}_{2}$ adsorption or coadsorption. Excellent $\mathrm{O}_{2}$ adsorption capability can be attributed to (i) its unsaturation sites and (ii) reaction as $\mathrm{BaO}+\frac{1}{2} \mathrm{O}_{2}(\mathrm{~g}) \Leftrightarrow \mathrm{BaO}_{2} \cdot{ }^{70} \mathrm{BaO}_{2}$ has been produced during NO decomposition on $\mathrm{BaO} / \mathrm{MgO} .^{10-12}$

\subsection{Nitrate Decomposition}

Temperature-programmed decomposition/desorption (TPDE/TPD) of nitrates in Figs. 714 shows that $\mathrm{NO}$ and $\mathrm{O}_{2}$ are the major decomposition products. TPD from 523 to $773 \mathrm{~K}$ for chelating bidentate nitrate (produced from $\mathrm{NO} / \mathrm{O}_{2}$ adsorption at $523 \mathrm{~K}$ ) on $\mathrm{Tb}_{4} \mathrm{O}_{7}, \mathrm{La}_{2} \mathrm{O}_{3}$, and $\mathrm{BaO}$ gave primarily $\mathrm{NO}$ and $\mathrm{O}_{2}$ product at a ratio of $\mathrm{NO} / \mathrm{O}_{2}$ of $4.5-3.9$, suggesting that reaction (I) is essentially reversible. About $80 \%$ of oxygen in chelating bidentate nitrate on $\mathrm{Tb}_{4} \mathrm{O}_{7}$ and $\mathrm{La}_{2} \mathrm{O}_{3}$ returned to the oxygen lattice form on the oxides.

Chelating bidentate nitrate appears to be the most stable form of nitrate on $\mathrm{Tb}_{4} \mathrm{O}_{7}, \mathrm{La}_{2} \mathrm{O}_{3}$, and $\mathrm{BaO}$. Bridging bidentate nitrate and other forms of nitrates which were produced from $\mathrm{NO} / \mathrm{O}_{2}$ adsorption decomposed at temperatures lower than chelating bidentate nitrate, producing $\mathrm{N}_{2} \mathrm{O}, \mathrm{N}_{2}, \mathrm{NO}_{2}$, in addition to $\mathrm{NO}$ and $\mathrm{O}_{2}$ on $\mathrm{Tb}_{4} \mathrm{O}_{7}, \mathrm{La}_{2} \mathrm{O}_{3}$, and $\mathrm{BaO}$. Bridging bidentate nitrate, a major nitrate, on $\mathrm{MgO}$ also produced $\mathrm{N}_{2} \mathrm{O}, \mathrm{N}_{2}$, and $\mathrm{NO}_{2}$. Formation of a small amount of $\mathrm{N}_{2}$ and $\mathrm{N}_{2} \mathrm{O}$ during TPDE/TPD of nitrates suggests the occurrence of $\mathrm{N}-\mathrm{O}$ bond dissociation and $\mathrm{N}-\mathrm{N}$ bond formation between these nitrate species. TPDE of the $\mathrm{Tb}\left(\mathrm{NO}_{3}\right)_{3}, \mathrm{La}\left(\mathrm{NO}_{3}\right)_{3}$, and $\mathrm{Ba}\left(\mathrm{NO}_{3}\right)_{2}$ produced more $\mathrm{N}_{2} \mathrm{O}$ than TPD of the nitrates produced from $\mathrm{NO} / \mathrm{O}_{2}$ adsorption as shown in Table 4. This observation indicates that these metal nitrates on $\mathrm{Al}_{2} \mathrm{O}_{3}$ in the forms of mixed nitrates 
(i.e. $\mathrm{NO}_{3}^{-}$, bridging and chelating bidentate nitrates) produced significantly more $\mathrm{N}_{2} \mathrm{O}$ than other forms of nitrates.

The infrared and mass spectrometer results reported here do not allow elucidation of the elementary steps involved in the $\mathrm{N}_{2}$ and $\mathrm{N}_{2} \mathrm{O}$ formation. Formation of $\mathrm{N}_{2}$ on $\mathrm{Tb}_{4} \mathrm{O}_{7}$ could be attributed to its non-stoichiometric nature and redox property. The formation of $\mathrm{N}_{2}$ from nitrate decomposition suggests the possibility of NO decomposition in an oxidizing environment through nitrates as follows:

$$
\mathrm{NO}+\mathrm{O}_{2} \Leftrightarrow \text { nitrate } \Rightarrow \mathrm{N}_{2}+\mathrm{N}_{2} \mathrm{O}+\mathrm{O}_{2}
$$

Formation of $\mathrm{N}_{2}, \mathrm{O}_{2}$, and $\mathrm{NO}_{2}$ has been observed during the decomposition of calcium nitrates. ${ }^{71}$ However, the amount of $\mathrm{N}_{2}$ produced remained too low to develop a practical process for NO removal. Isolation of the site and determination of the steps involved in the product formation may lead to development of an effective NO decomposition catalyst for removal of NO in an oxidizing environment.

\section{Conclusion}

Infrared spectroscopy coupled with mass spectroscopy allows determination of the form of $\mathrm{NO}_{x}$ storage during $\mathrm{NO} / \mathrm{O}_{2}$ adsorption and its behavior during temperature-programmed decomposition/desorption. $\mathrm{NO} / \mathrm{O}_{2}$ coadsorbed as bridging and chelating bidentate nitrates and monodentate nitrate on $\mathrm{Tb}_{4} \mathrm{O}_{7}, \mathrm{La}_{2} \mathrm{O}_{3}$, and $\mathrm{BaO}$, and as bridging bidentate nitrate and monodentate nitrate on $\mathrm{MgO}$ via the reaction of adsorbed $\mathrm{NO}$ with adsorbed oxygen at $298 \mathrm{~K}$. $\mathrm{NO} / \mathrm{O}_{2}$ coadsorbed as a chelating bidentate nitrate on $\mathrm{Tb}_{4} \mathrm{O}_{7}$ and $\mathrm{La}_{2} \mathrm{O}_{3}$, and as a distinctive bridging bidentate nitrate on $\mathrm{BaO}$ and $\mathrm{MgO}$ via the reaction of adsorbed $\mathrm{NO}$ with surface lattice oxygen at $523 \mathrm{~K}$. 
TPD of chelating bidentate nitrate on $\mathrm{Tb}_{4} \mathrm{O}_{7}, \mathrm{La}_{2} \mathrm{O}_{3}$, and $\mathrm{BaO}$ produced primarily $\mathrm{NO}$ and $\mathrm{O}_{2}$ with maxima at 640 and $670 \mathrm{~K}$, respectively. TPD of bridging bidentate nitrate and monodentate nitrate on $\mathrm{Tb}_{4} \mathrm{O}_{7}, \mathrm{La}_{2} \mathrm{O}_{3}$, and $\mathrm{BaO}$ produced $\mathrm{NO}$ and $\mathrm{O}_{2}$ as major products and $\mathrm{N}_{2}$ and $\mathrm{N}_{2} \mathrm{O}$ as minor products at $320-500 \mathrm{~K}$. Decomposition of bridging bidentate on $\mathrm{MgO}$ produced $\mathrm{NO}$ as a major product and $\mathrm{N}_{2} \mathrm{O}$ as a minor product at a peak temperature of $690 \mathrm{~K}$. Observation of $\mathrm{NO}$ and $\mathrm{O}_{2}$ as major products of chelating and bridging bidentate nitrate decomposition suggests the formation of these nitrates from $\mathrm{NO}$ and $\mathrm{O}_{2}$ are essentially reversible without involvement of $\mathrm{NO}_{2}$ as an intermediate. Peak temperature for $\mathrm{Tb}\left(\mathrm{NO}_{3}\right)_{3}, \mathrm{La}\left(\mathrm{NO}_{3}\right)_{3}$, $\mathrm{Ba}\left(\mathrm{NO}_{3}\right)_{2}$, and $\mathrm{Mg}\left(\mathrm{NO}_{3}\right)_{2}$ decomposition occurred between those for bridging and chelating nitrates. The difference in reactivity and stability of chelating and bridging bidentate nitrates on various oxides may provide a wide range of operating temperature for $\mathrm{NO}_{x}$ storage. Formation of $\mathrm{N}_{2}$ from decomposition of various forms of nitrates suggests the need for the identification of the step involved in conversion of nitrate to $\mathrm{N}_{2}$. Identification of this step may guide the development of the oxide for conversion of $\mathrm{NO}$ in oxidizing environment to $\mathrm{N}_{2}$ and $\mathrm{O}_{2}$ via metal nitrates.

\section{Acknowledgement}

The authors gratefully acknowledge the partial support of this research by the United States Department of Energy under grant DE-FG22-95PC955224 and the Ohio Boards of Regents Research Challenge Grant. The assistance from Bei Chen and Pisanu Toochinda in performing these experiments is also appreciated.

\section{References}

(1) Taylor, K. C. Catal. Rev.-Sci. Eng. 1993, 35, 457.

(2) Masel, R. I. Catal. Rev.-Sci. Eng. 1986, 28, 335. 
(3) Viswanathan, B. Catal. Rev.-Sci. Eng. 1992, 34, 337.

(4) Tabata, K.; Misono, M. Catal Today, 1990, 8, 249.

(5) Iwamoto, M. Catal Today, 1994, 22, 1.

(6) Shelef, M. Catal. Rev.-Sci. Eng. 1995, 95, 209.

(7) Yan, J. Y.; Satchtler, W. M. H.; Kung, H.H. Catal Today, 1997, 33, 279.

(8) Amiridis, M. D.; Zhuang, T.; Farrauto, R. J. Appl. Catal. B 1996, 10, 203.

(9) Li, Y.; Armor, L. Appl. Catal. B 1995, 5, L257.

(10) Xie, S.; Mestl, G.; Rosynek, M. P.; Lunsford, J. H. J. Am. Chem. Soc. 1997, 119, 10186.

(11) Mestl, G.; Rosynek, M. P.; Lunsford, J. H. J. Phys. Chem. B. 1997, 101, 9321.

(12) Mestl, G.; Rosynek, M. P.; Lunsford, J. H. J. Phys. Chem. B. 1997, 101, 9329.

(13) Busca, G.; Lietti, L.; Ramis, G.; Berti, F. Appl. Catal. B 1998, $18,1$.

(14) Amiridis, M. D.; Duevel, R. V.; Waches, I. E. Appl. Catal. B 1999, 20, 111.

(15) Iwamoto, M.; Furukawa, H.; Mine, Y.; Uemura, F.; Mikuriya, S.; Kagawa, S. J. Chem. Soc., Chem. Commun. 1986, 16, 1272.

(16) Valyon, J.; Hall, W. K. J. Phys. Chem. 1993, 97, 1204.

(17) Aylor, A. W.; Larsen, S. C.; Reimer, J. A.; Bell A. T. J. Catal. 1995, 157, 592.

(18) Li, Y.; Armor, J. N. Appl. Catal. B 1991, 76, L1.

(19) Curtin, T.; Delmon, B. Catal Today, 1997, 35, 121.

(20) Chuang, S. S. C.; Tan, C.-D. J. Phys. Chem. B . 1997, 101, 3000.

(21) Machida, M.; Yasuoka, K.; Eguchi, K.; Arai, H. .J. Chem. Soc., Chem. Commun. 1990, 1, 1165 .

(22) Takahashi, N.; Shinjoh, H.; Ijjima, T.; Suzuki, T.; Yamazaki, K.; Yokata, K.; Suzuki, H.; Miyoshi, N.; Matsumoto, S.; Tanizawa, T.; Tanaka, T.; Tateishi, S.; Kasahara, K. Catal. Today, 1996, 27, 63. 
(23) Eguchi, K.; Watabe, M.; Machida, M.; Arai, H. Catal. Today, 1996, 27, 297.

(24) Mahzoul, H.; Brilhac, J. F.; Gilot, P. Appl. Catal. B 1999, $20,47$.

(25) Shimokawabe, M.; Tadokoro, K.; Sasaki, S.; Takezawa, N. Appl. Catal. A 1998, $16,215$.

(26) Bernal, S.;Blanco, G.; Cauqui, M. A.; Corchado, P.; Pintado, J. M.; Rodriguez-Izquierdo, J. M. Chem. Commun. 1997, 16, 1545.

(27) Klingenberg, B.; Vannice, M. A. Appl. Catal. B 1999, 21, 19.

(28) Zhang, X.; Walters, A. B.; Vannice, M. A. J. Catal. 1996, 159, 119.

(29) Munakata, F.; Akimune, Y.; Shichi, Y.; Ymaguchi, H.; Inoue, Y. Chem. Commun. 1997, 1, 63.

(30) Gordatos, H.; Gorte, R. J. Appl. Catal. B 1995, 7, 33.

(31) Fridell, E.; Skoglundh, M.; Westerberg, B.; Johnsson, S.; Smdler, G. J. Catal. 1999, 183, 196.

(32) Acke, F.; Skoglundh, M. J. Phys. Chem. B. 1999, 103, 972.

(33) Stark, J. V.; Klabunde, K. J. Chem. Mater. 1996, 8, 1913.

(34) Cerruti, L.; Modone, E.; Guglielminotti, E.; Borello, E. J. Chem. Soc., Faraday Trans. 1. 1974, 70, 729.

(35) Chuang, S. S. C.; Brundage, M. A.; Balakos, M. W.; Srinivas, G. Appl. Spectrosc. 1995, 49, 1151.

(36) Vratny, F. Appl. Spectrosc. 1959, 13, 59.

(37) Addison, C. C.; Gatehouse, B. M. J. Chem. Soc. 1960, 613.

(38) Ferraro, J. R. J. Mol. Spectrosc. 1960, 4, 99.

(39) Nyquist, R. A.; Kagel, R. O. Infrared Spectra of Inorganic Compounds, Academic Press: New York and London, 1971.

(40) Laane, J.; Ohlsen, J. R. Progress in Inorganic Chemistry, 1980, 27, 465.

(41) Outka, D. A.; Madix, R. J. Surface Sci. 1987, 179, 1.

(42) Hadjiivanov, K.; Klissurski, D.; Ramis, G.; Busca, G. Appl. Catal. B 1996, 7, 251. 
(43) Delahay, G.; Coq, B.; Ensuque, E.; Figuéras, F. Langmuir, 1997, 13, 5588.

(44) Nakamoto, K. Infrared and Raman Spectra of Inorganic and Coordination Compounds, 4th ed.; Wiley: New York, 1986.

(45) Davynov, A. A., Infrared Spectra of Adsorbed Species on the Surface of Transition Metal Oxides, (Rochester, C. H. Ed.); John Wiley \& Sons: England, 1990.

(46) Jenkins, R.; Snyder, R. L. Introduction to X-ray Powder Diffraction, John Wiley \& Sons: England, 1996; Chapter 3.

(47) Xie, Y.-C.; Tang, Y.-Q., Adv. Catal., 1990, 37,1.

(48) Krim, L.; Lacome, N. J. Phys. Chem. B. 1998, 102, 2289.

(49) Terenin, A.; Reov, L. Spectrochimica Acta 1959, 11, 946.

(50) Xu, X.; Chen, P.; Goodman, D. W. J. Phys. Chem. B. 1994, 98, 9242.

(51) Hoost, T. E.; Otto, K.; Laframboise, K. A. J. Catal. 1995, 155, 303.

(52) Almusaiteer, K.; Chuang, S. S. C. J. Catal. 1998, 180, 161.

(53) Henrich, V. E.; Cox, P. A. Appl. Surf. Sci.1993, 72, 277.

(54) Martínez-Arias, A.; Soria, J.; Conesa, J. C.; Seoane, X. L.; Arcoya, A.; Cataluña, R. J. Chem. Soc., Faraday Trans. 1. 1995, 91, 1679.

(55) Yanagisawa, Y. Appl. Surf. Sci. 1995, 89, 251.

(56) Forni, L.; Oliva, C.; Barzetti, T.; Selli, E.; Ezerets, A. M.; Vishniakov, A. V. Appl. Catal. B 1997, 13, 35 .

(57) Che, M.; Tench, A. J. Adv. Catal. 1983, 32, 1.

(58) Bielański, A.; Haber, J. Oxygen in Catalysis, Marcel Dekker, Inc., New York, 1991.

(59) Borchert, H.; Baerns, M. J. Catal. 1997, 168, 315.

(60) Lunsford, J. H. Catal. Rev. 1973, 8, 135.

(61) Iwamoto, M.; Yoda, Y.; Yamazoe, N.; Seiyama, T. J. Phys. Chem. 1978, 82, 2564. 
(62) Al-Mashta, F.; Sheppard, N.; Lorenzell, V.; Busca, G. J. Chem. Soc., Faraday Trans.1. 1982, 78, 979.

(63) Kung, H. H. Stud. Surf. Sci. Catal. 1989, 45, 1.

(64) Henrich, V. E.; Cox, P. A. The Surface Science of Metal Oxides, Cambridge University Press, 1994.

(65) Holmgren, A.; Duprez, D.; Andersson, B. J. Catal. 1999, 182, 441.

(66) Balasubramanian, S. Master thesis, The University of Akron, 1998; P64.

(67) Schraml-Marth, M.; Wokaun, A.; Baiker, A. J. Catal. 1992, 138, 306.

(68) Gates, B. C. Catalytic Chemistry, John Wiley \& Sons, Inc: 1992.

(69) Chi, Y.; Chuang, S. S. C. J. Catal. in press, 1999.

(70) Perry, D. L.; Philipps, S. L. Handbook of Inorganic Compounds, CRC Press, Inc. 1995; P54.

(71) Ettarh, C.; Galwey, A. K. Thermochim. Acta, 1996, 288, 203. 


\section{Table List}

1. Loading of nitrates and metal oxides on $\gamma-\mathrm{Al}_{2} \mathrm{O}_{3}$ and particle size

2. The amount of $\mathrm{NO}$ and $\mathrm{O}_{2}$ adsorption on various metal oxides $/ \gamma-\mathrm{Al}_{2} \mathrm{O}_{3}$ at 298 and $523 \mathrm{~K}$

3. IR band assignment of adsorbates produced from flowing $0.08 \% \mathrm{NO}$ and $2 \% \mathrm{O}_{2}$ over various metal oxides $/ \gamma-\mathrm{Al}_{2} \mathrm{O}_{3}$ at $298 \mathrm{~K}$ and $523 \mathrm{~K}$.

4. Amount of the decomposed and desorbed product of $\gamma-\mathrm{Al}_{2} \mathrm{O}_{3}$ supported nitrates and adsorbed nitrates produced from flowing $0.08 \% \mathrm{NO} / 2 \% \mathrm{O}_{2}$ during temperature-programmed decomposition/desorption (TPDE/TPD) 
Table 1

Loading of nitrates and metal oxides on $\gamma-\mathrm{Al}_{2} \mathrm{O}_{3}$ and particle size

\begin{tabular}{|c|c|c|c|c|c|}
\hline \multirow[t]{2}{*}{ Species } & \multirow{2}{*}{$\begin{array}{c}\mathrm{wt} \% \text { in } \\
\mathrm{M}\left(\mathrm{NO}_{3}\right)_{\mathrm{n}}\end{array}$} & \multirow{2}{*}{$\begin{array}{l}\mathrm{wt} \% \text { in } \\
\mathrm{M}_{\mathrm{x}} \mathrm{O}_{\mathrm{y}}\end{array}$} & \multirow{2}{*}{$\begin{array}{c}\mathrm{wt} \% \text { in } \mathrm{M}_{\mathrm{x}} \mathrm{O}_{\mathrm{y}} \\
\text { needed for monolayer }\end{array}$} & \multicolumn{2}{|c|}{ XRD analysis } \\
\hline & & & & crystal & particle size $(\stackrel{0}{A})$ \\
\hline$\overline{\mathrm{Tb}}$ & 25.7 & $15.8\left(\mathrm{~Tb}_{4} \mathrm{O}_{7}\right)$ & 12.4 & $\mathrm{~Tb}_{4} \mathrm{O}_{7}$ & 105 \\
\hline $\mathrm{La}$ & 24.5 & $15.0\left(\mathrm{La}_{2} \mathrm{O}_{3}\right)$ & 5.4 & - & - \\
\hline $\mathrm{Ba}$ & 14.6 & $9.2(\mathrm{BaO})$ & 2.5 & $\mathrm{BaO}$ & 198 \\
\hline $\mathrm{Mg}$ & 9.7 & $1.7(\mathrm{MgO})$ & 0.7 & - & - \\
\hline
\end{tabular}

${ }^{a}$ estimated by packed monolayer model according to ref. (47). 
Table 2

The amount of $\mathrm{NO}$ and $\mathrm{O}_{2}$ adsorption on various metal oxides $/ \gamma-\mathrm{Al}_{2} \mathrm{O}_{3}$ at 298 and $523 \mathrm{~K}$

\begin{tabular}{|c|c|c|c|c|}
\hline \multirow[t]{2}{*}{ Metal oxides } & \multicolumn{2}{|c|}{ At $298 \mathrm{~K}\left(\mu \mathrm{mol} / \mathrm{g} \mathrm{cat}^{\mathrm{a}}.\right)$} & \multicolumn{2}{|c|}{ At $523 \mathrm{~K}\left(\mu \mathrm{mol} / \mathrm{g} \mathrm{cat}^{\mathrm{a}}.\right)$} \\
\hline & NO & $\mathrm{O}_{2}$ & $\mathrm{NO}$ & $\mathrm{O}_{2}$ \\
\hline $\mathrm{Tb}_{4} \mathrm{O}_{7} / \mathrm{Al}_{2} \mathrm{O}_{3}$ & 511 & 568 & 91 & 34 \\
\hline $\mathrm{La}_{2} \mathrm{O}_{3} / \mathrm{Al}_{2} \mathrm{O}_{3}$ & 376 & 546 & 125 & 57 \\
\hline $\mathrm{BaO} / \mathrm{Al}_{2} \mathrm{O}_{3}$ & 724 & 1171 & 213 & 160 \\
\hline $\mathrm{MgO} / \mathrm{Al}_{2} \mathrm{O}_{3}$ & 377 & 32 & 226 & $<5$ \\
\hline
\end{tabular}

metal oxide $/ \gamma-\mathrm{Al}_{2} \mathrm{O}_{3}$. 
Table 3

IR band assignment of adsorbates produced from flowing $0.08 \% \mathrm{NO}$ and $2 \% \mathrm{O}_{2}$ over various metal oxides $/ \gamma-\mathrm{Al}_{2} \mathrm{O}_{3}$ at $298 \mathrm{~K}$ and $523 \mathrm{~K}$.

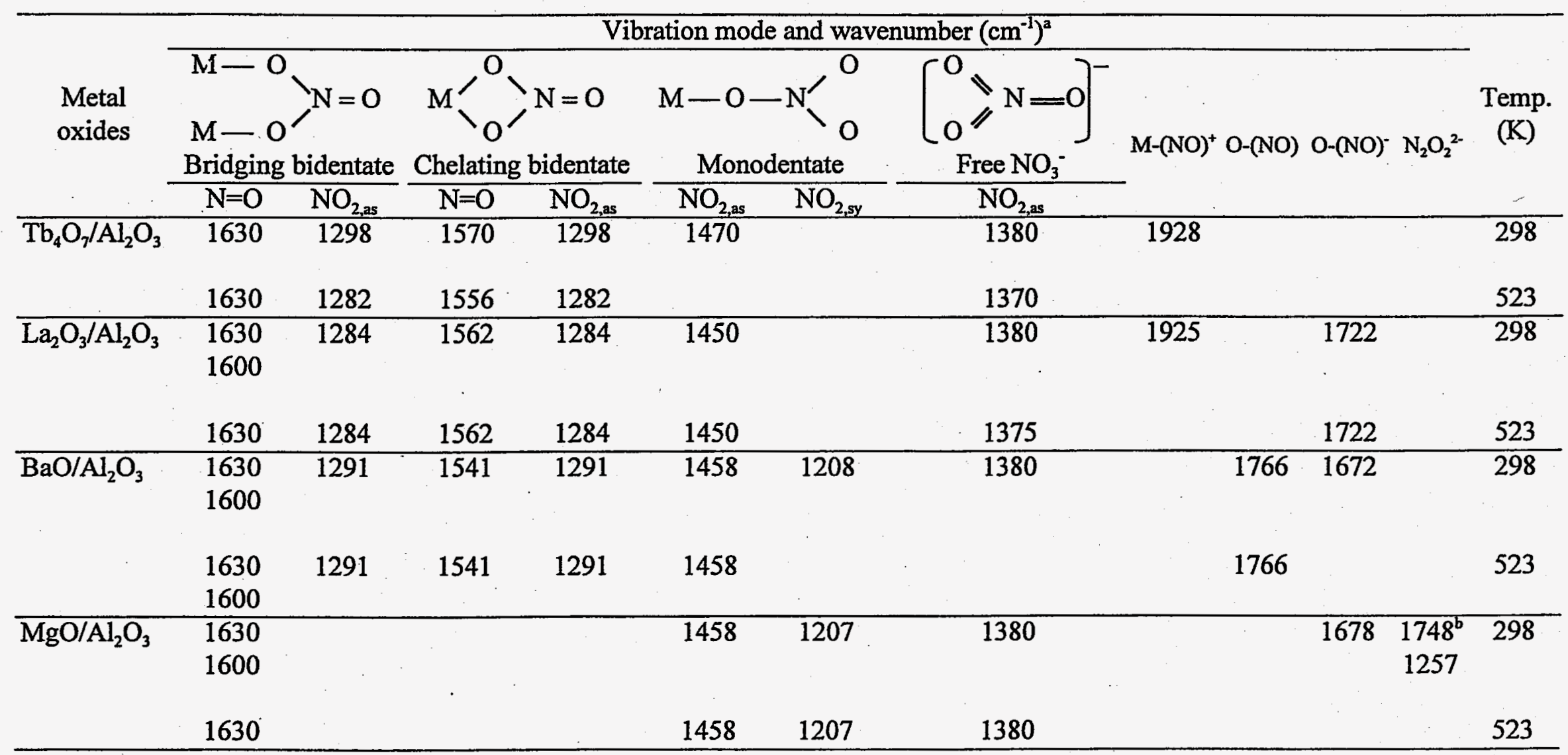

a ref. $(16-34,36-45)$.

b ref. $(34,38)$. 
Table 4

Amount of the decomposed and desorbed product of $\gamma-\mathrm{Al}_{2} \mathrm{O}_{3}$ supported nitrates and adsorbed nitrates produced from flowing $0.08 \%$ $\mathrm{NO} / 2 \% \mathrm{O}_{2}$ during temperature-programmed decomposition/desorption (TPDE/TPD)

\begin{tabular}{|c|c|c|c|c|c|c|c|c|c|c|c|}
\hline \multirow{2}{*}{$\begin{array}{l}\text { Nitrates and } \\
\text { Metal oxides }\end{array}$} & \multirow{2}{*}{$\begin{array}{l}\mathrm{NO}_{\mathrm{x}} \text { storage } \\
\text { ability }(\%)\end{array}$} & \multicolumn{9}{|c|}{ Amount of decomposed and desorbed product $(\mu \mathrm{mol})$} & \multirow[t]{2}{*}{ TPDE/TPD } \\
\hline & & NO & $\mathrm{N}_{2}$ & $\mathrm{~N}_{2} \mathrm{O}$ & $\mathrm{NO}_{2}$ & $\mathrm{O}_{2}$ & $\mathrm{~N}_{\text {total }}$ & $\mathrm{O}_{\text {total }}$ & $\mathrm{N} / \mathrm{O}$ & $\mathrm{NO} / \mathrm{O}_{2}$ & \\
\hline $\mathrm{Tb}\left(\mathrm{NO}_{3}\right)_{3} / \mathrm{Al}_{2} \mathrm{O}_{3}$ & & 137 & 9.5 & 24 & 4 & 11 & 207 & 191 & 1.1 & 12.5 & $298-753 \mathrm{~K}(\mathrm{TPDE})$ \\
\hline \multirow{2}{*}{$\mathrm{Tb}_{4} \mathrm{O}_{7} / \mathrm{Al}_{2} \mathrm{O}_{3}$} & 57.8 & 34 & 3 & 1.4 & 0.2 & 7.1 & $43(96 \%)^{b}$ & $50(34 \%)^{c}$ & 0.9 & 4.8 & $298-753 \mathrm{~K}(\mathrm{TPD})$ \\
\hline & 10.8 & 6.8 & 0.6 & trace & trace & 1.5 & $8(100 \%)$ & $9.8(70 \%)$ & 0.8 & 4.5 & $523-753 \mathrm{~K}(\mathrm{TPD})$ \\
\hline $\mathrm{La}\left(\mathrm{NO}_{3}\right)_{3} / \mathrm{Al}_{2} \mathrm{O}_{3}$ & & 115 & 7 & 22 & 0.5 & 13 & 173.5 & 164 & 1.1 & 8.8 & $298-753 \mathrm{~K}(\mathrm{TPDE})$ \\
\hline \multirow[t]{2}{*}{$\mathrm{La}_{2} \mathrm{O}_{3} / \mathrm{Al}_{2} \mathrm{O}_{3}$} & 42.3 & 28 & 1.3 & 0.5 & 0.3 & 8.2 & $31.9(97 \%)$ & $45.5(35 \%)$ & 0.7 & 3.4 & $298-753 \mathrm{~K}(\mathrm{TPD})$ \\
\hline & 13.7 & 9.8 & 0.3 & none & trace & 2.1 & $10.4(95 \%)$ & $14.0(67 \%)$ & 0.7 & 4.7 & $523-753 \mathrm{~K}(\mathrm{TPD}))$ \\
\hline $\mathrm{BaNO}_{3} / \mathrm{Al}_{2} \mathrm{O}_{3}$ & & 83 & 8 & 6 & 1.3 & 10 & 112.3 & 111.6 & 1.0 & 8.3 & $298-753 \mathrm{~K}(\mathrm{TPDE})$ \\
\hline \multirow[t]{2}{*}{$\mathrm{BaO} / \mathrm{Al}_{2} \mathrm{O}_{3}$} & 118.2 & 62 & 1.3 & 0.6 & 0.4 & 20 & $66.2(97 \%)$ & $103.4(40 \%)$ & 0.6 & 3.1 & $298-753 \mathrm{~K}(\mathrm{TPD})$ \\
\hline & 33.2 & 18 & 0.2 & trace & 0.2 & 4.6 & $18.6(93 \%)$ & $27.6(55 \%)$ & 0.7 & 3.9 & $523-753 \mathrm{~K}$ (TPD) \\
\hline $\mathrm{MgNO}_{3} / \mathrm{Al}_{2} \mathrm{O}_{3}$ & & 57 & 0.7 & 4 & 1.2 & none & 67.6 & 63.4 & 1.1 & $\infty^{d}$ & $298-753 \mathrm{~K}(\mathrm{TPDE})$ \\
\hline \multirow[t]{2}{*}{$\mathrm{MgO} / \mathrm{Al}_{2} \mathrm{O}_{3}$} & 87.8 & 31 & none & 0.8 & 0.8 & none & $33.4(95 \%)$ & $33.4(81 \%)$ & 1.0 & $\infty^{d}$ & $298-753 \mathrm{~K}(\mathrm{TPD})$ \\
\hline & 54.5 & 19 & none & 0.7 & 0.3 & none & $20.7(98 \%)$ & $20.3(97 \%)$ & 1.0 & $\infty^{d}$ & $523-753 \mathrm{~K}(\mathrm{TPD})$ \\
\hline
\end{tabular}

a storage ability $=\frac{\text { Total amount of } \mathrm{N} \text { element of desorbed product during TPD ( } \mu \mathrm{mol} / 0.1 \mathrm{~g} \text { cat.) }}{\text { Total amount of metal cation in metal oxide } / \gamma-\mathrm{Al}_{2} \mathrm{O}_{3}(\mu \mathrm{mol} / 0.1 \mathrm{~g} \text { cat. })} \times 100 \%$

${ }^{b}$ ratio of desorbed $\mathrm{N}$ to adsorbed $\mathrm{NO}$ in parenthesis.

${ }^{c}$ ratio of desorbed $\mathrm{O}$ to adsorbed $\mathrm{O}$ element in parenthesis.

-d $\mathrm{No}_{2}$ was produced. 


\section{Figure Caption:}

Fig.1 Experimental approach: (a) temperature-programmed decomposition of $\mathrm{Tb}\left(\mathrm{NO}_{3}\right)_{3} / \mathrm{Al}_{2} \mathrm{O}_{3}$, (b) adsorption of $\mathrm{NO}$ and $\mathrm{O}_{2}$ on $\mathrm{Tb}_{4} \mathrm{O}_{7} / \mathrm{Al}_{2} \mathrm{O}_{3}$ at $298 \mathrm{~K}$, and (c) temperature-programmed desorption of $\mathrm{NO}_{\mathrm{x}}$ adsorbates on $\mathrm{Tb}_{4} \mathrm{O}_{7} / \mathrm{Al}_{2} \mathrm{O}_{3}$ from 298 to $773 \mathrm{~K}$.

Fig.2 IR spectra of (a) original nitrates and (b) nitrates $/ \mathrm{Al}_{2} \mathrm{O}_{3}$ at $298 \mathrm{~K}$.

Fig.3 X-ray diffraction patterns of decomposed nitrates $/ \mathrm{Al}_{2} \mathrm{O}_{3}$.

Fig.4 MS profiles and in situ IR spectra during $0.08 \%$ NO and $2 \% \mathrm{O}_{2}$ adsorption on $\mathrm{Tb}_{4} \mathrm{O}_{7} / \mathrm{Al}_{2} \mathrm{O}_{3}$ at $298 \mathrm{~K}(\mathrm{a}, \mathrm{b})$ and $523 \mathrm{~K}(\mathrm{c}, \mathrm{d})$.

Fig.5 In situ IR spectra during $0.08 \% \mathrm{NO}$ and $2 \% \mathrm{O}_{2}$ adsorption on $\mathrm{La}_{2} \mathrm{O}_{3} / \mathrm{Al}_{2} \mathrm{O}_{3}, \mathrm{BaO} / \mathrm{Al}_{2} \mathrm{O}_{3}$, and $\mathrm{MgO} / \mathrm{Al}_{2} \mathrm{O}_{3}$ at $298 \mathrm{~K}$ and $523 \mathrm{~K}$.

Fig.6 Normalized product MS profiles of (a) thermal decomposition of $\mathrm{Tb}\left(\mathrm{NO}_{3}\right)_{3}$ on $\mathrm{Al}_{2} \mathrm{O}_{3}$, (b) TPD of adsorbates on $\mathrm{Tb}_{4} \mathrm{O}_{7} / \mathrm{Al}_{2} \mathrm{O}_{3}$ from 298 to $773 \mathrm{~K}$, and (c) TPD of adsorbates on $\mathrm{Tb}_{4} \mathrm{O}_{7} / \mathrm{Al}_{2} \mathrm{O}_{3}$ from 298 to $773 \mathrm{~K}$.

Fig.7 In situ IR spectra during TPD of adsorbates on $\mathrm{Tb}_{4} \mathrm{O}_{7} / \mathrm{Al}_{2} \mathrm{O}_{3}$ from $298 / 523$ to $773 \mathrm{~K}$ as well as IR spectra of $\mathrm{Tb}\left(\mathrm{NO}_{3}\right)_{3} \cdot \mathrm{H}_{2} \mathrm{O} / \mathrm{Al}_{2} \mathrm{O}_{3}$ and $\mathrm{Tb}\left(\mathrm{NO}_{3}\right)_{3} \cdot 6 \mathrm{H}_{2} \mathrm{O}$ at $298 \mathrm{~K}$.

Fig.8 Normalized product MS profiles of (a) thermal decomposition of $\mathrm{La}\left(\mathrm{NO}_{3}\right)_{3}$ on $\mathrm{Al}_{2} \mathrm{O}_{3}$, (b) TPD of adsorbates on $\mathrm{La}_{2} \mathrm{O}_{3} / \mathrm{Al}_{2} \mathrm{O}_{3}$ from 298 to $773 \mathrm{~K}$, and (c) TPD of adsorbates on $\mathrm{La}_{2} \mathrm{O}_{3} / \mathrm{Al}_{2} \mathrm{O}_{3}$ from 298 to $773 \mathrm{~K}$.

Fig.9 In situ IR spectra during TPD of adsorbates on $\mathrm{La}_{2} \mathrm{O}_{3} / \mathrm{Al}_{2} \mathrm{O}_{3}$ from $298 / 523$ to $773 \mathrm{~K}$ as well as IR spectra of $\mathrm{La}\left(\mathrm{NO}_{3}\right)_{3} \cdot \mathrm{H}_{2} \mathrm{O} / \mathrm{Al}_{2} \mathrm{O}_{3}$ and $\mathrm{La}\left(\mathrm{NO}_{3}\right)_{3} \cdot 6 \mathrm{H}_{2} \mathrm{O}$ at $298 \mathrm{~K}$.

Fig.10 Normalized product MS profiles of (a) thermal decomposition of $\mathrm{Ba}\left(\mathrm{NO}_{3}\right)_{2}$ on $\mathrm{Al}_{2} \mathrm{O}_{3}$, (b) TPD of adsorbates on $\mathrm{BaO} / \mathrm{Al}_{2} \mathrm{O}_{3}$ from 298 to $773 \mathrm{~K}$, and (c) TPD of adsorbates on $\mathrm{BaO} / \mathrm{Al}_{2} \mathrm{O}_{3}$ from 298 to $773 \mathrm{~K}$.

Fig.11 In situ IR spectra during TPD of adsorbates on $\mathrm{BaO} / \mathrm{Al}_{2} \mathrm{O}_{3}$ from $298 / 523$ to $773 \mathrm{~K}$ as well as IR spectra of $\mathrm{Ba}\left(\mathrm{NO}_{3}\right)_{2} \cdot \mathrm{H}_{2} \mathrm{O} / \mathrm{Al}_{2} \mathrm{O}_{3}$ and $\mathrm{Ba}\left(\mathrm{NO}_{3}\right)_{2}$ at $298 \mathrm{~K}$.

Fig.12 Normalized product MS profiles of (a) thermal decomposition of $\mathrm{Mg}\left(\mathrm{NO}_{3}\right)_{2}$ on $\mathrm{Al}_{2} \mathrm{O}_{3}$, (b) TPD of adsorbates on $\mathrm{MgO} / \mathrm{Al}_{2} \mathrm{O}_{3}$ from 298 to $773 \mathrm{~K}$, and (c) TPD of adsorbates on $\mathrm{MgO} / \mathrm{Al}_{2} \mathrm{O}_{3}$ from 298 to $773 \mathrm{~K}$.

Fig.13 In situ IR spectra during TPD of adsorbates on $\mathrm{MgO} / \mathrm{Al}_{2} \mathrm{O}_{3}$ from $298 / 523$ to $773 \mathrm{~K}$ as well as IR spectra of $\mathrm{Mg}\left(\mathrm{NO}_{3}\right)_{2} \cdot \mathrm{H}_{2} \mathrm{O} / \mathrm{Al}_{2} \mathrm{O}_{3}$ and $\mathrm{Mg}\left(\mathrm{NO}_{3}\right)_{2} \cdot 6 \mathrm{H}_{2} \mathrm{O}$ at $298 \mathrm{~K}$. 
(a) Temperature-programmed decomposition of $\mathrm{Tb}\left(\mathrm{NO}_{3}\right)_{3} / \mathrm{Al}_{2} \mathrm{O}_{3}$
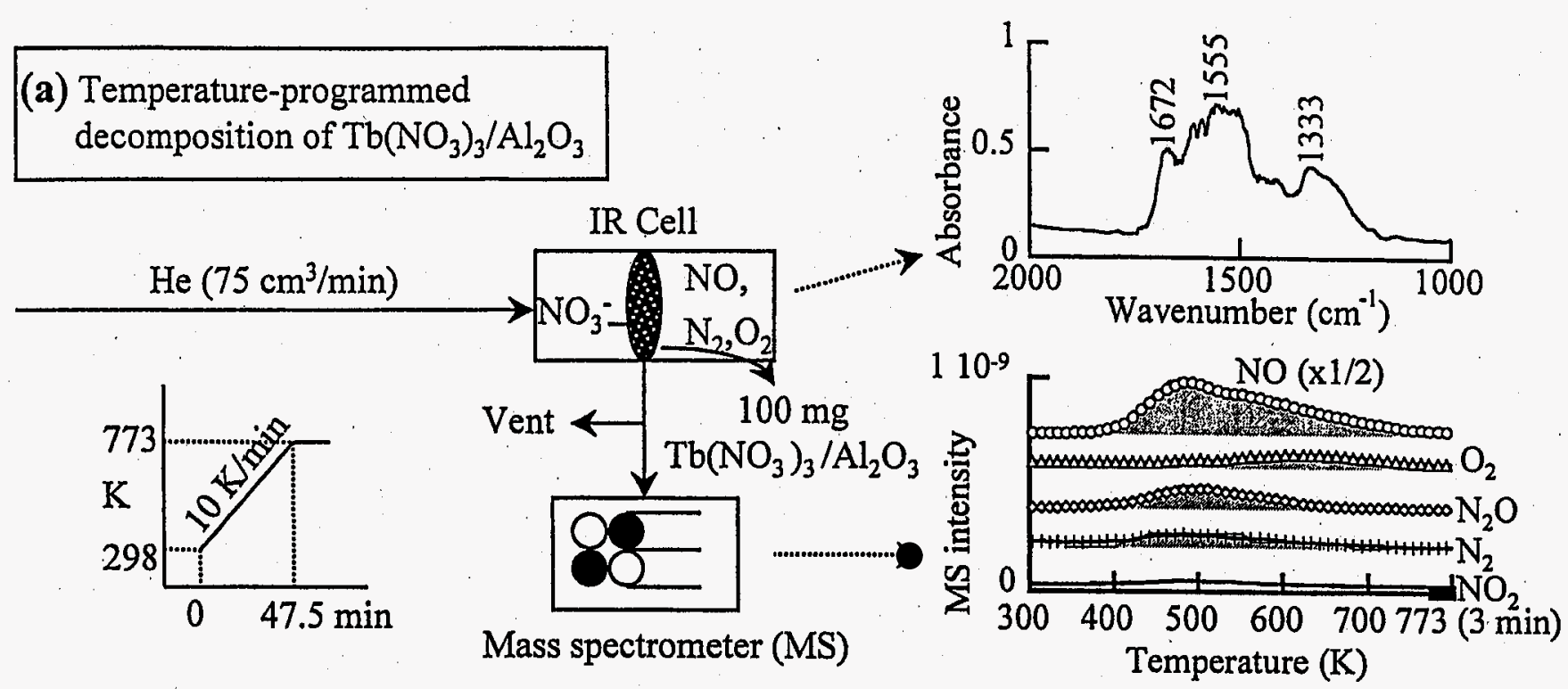

(b) Adsorption of $\mathrm{NO}$ and $\mathrm{O}_{2}$

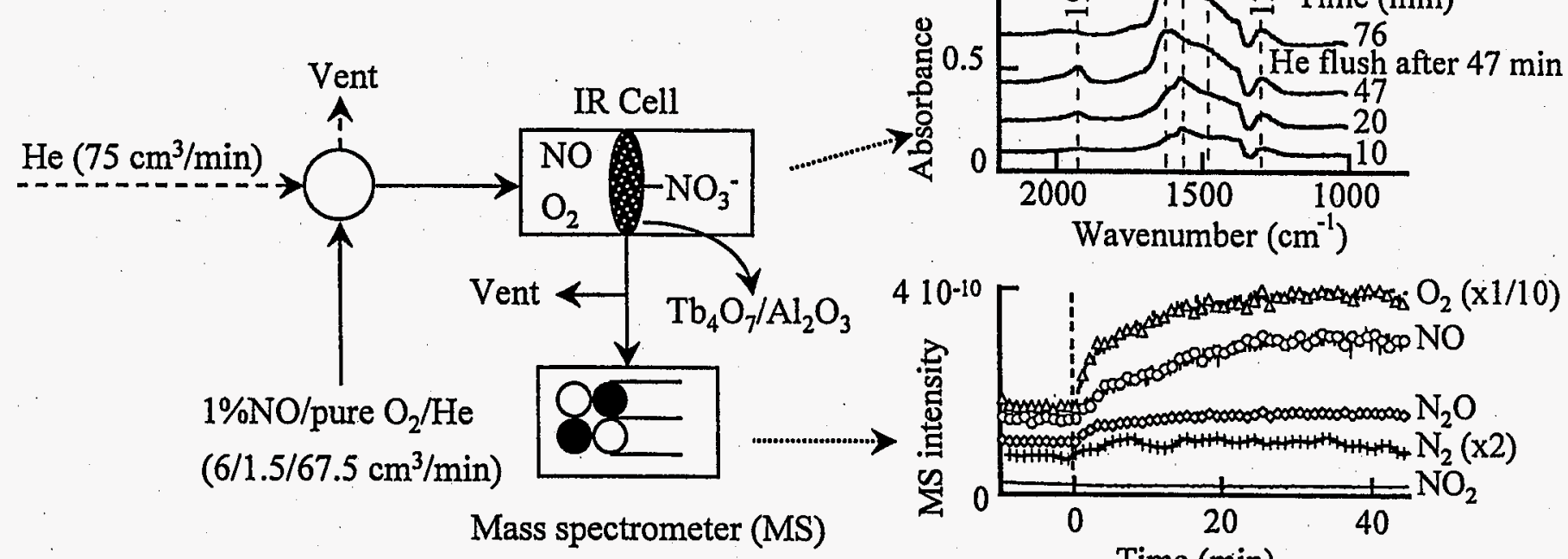

(c) Temperature-programmed desorption

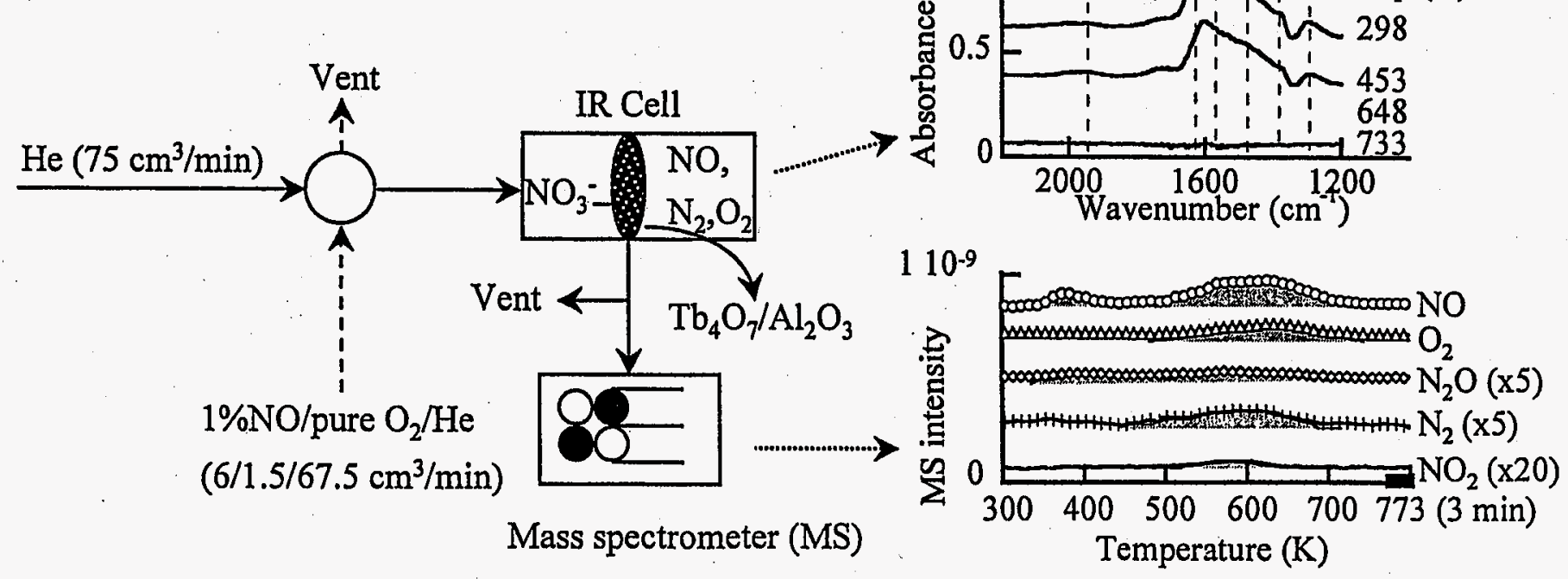

Fig.1 Chi \& Chuang 


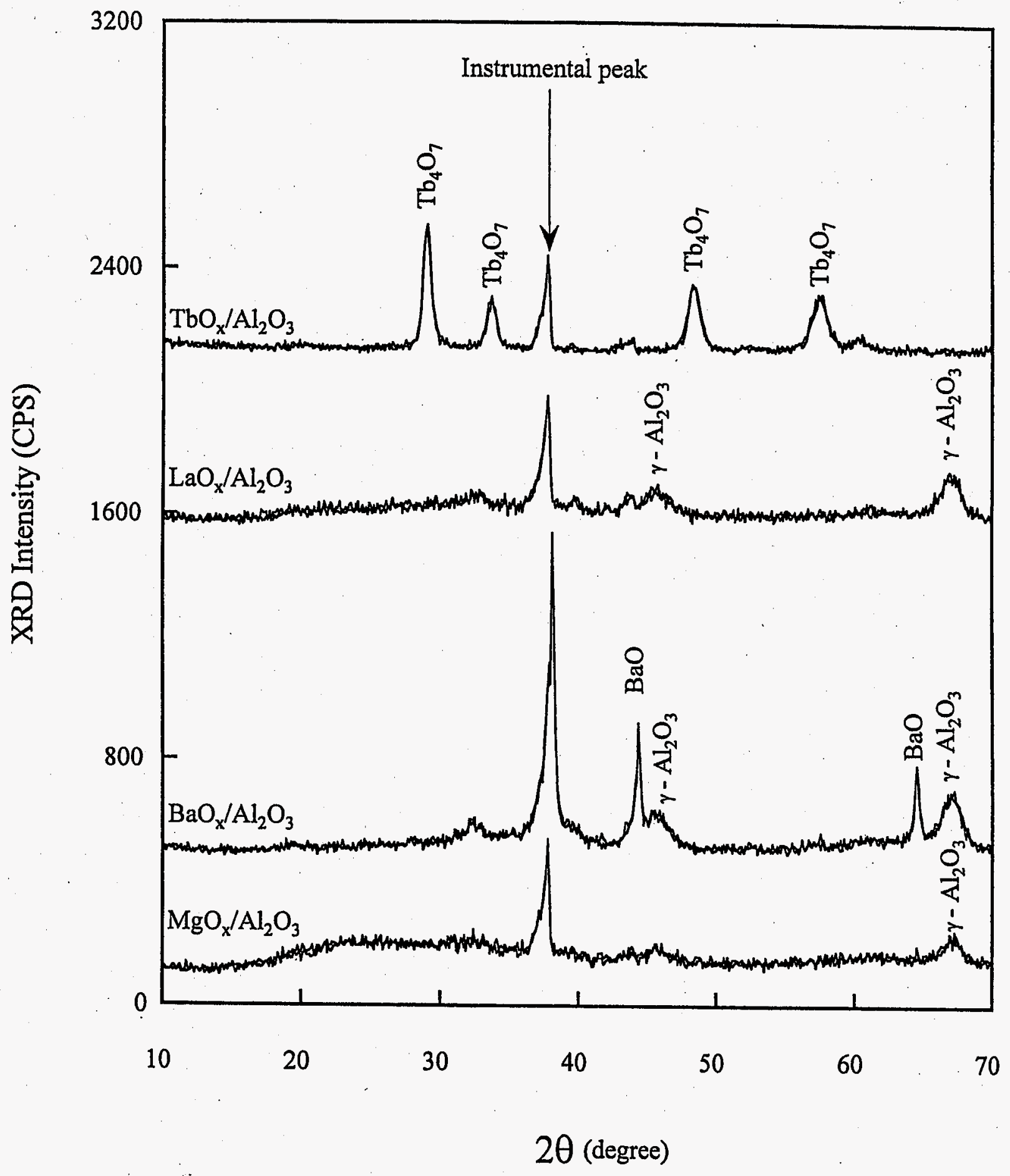

Fig.3 Chi \& Chuang 

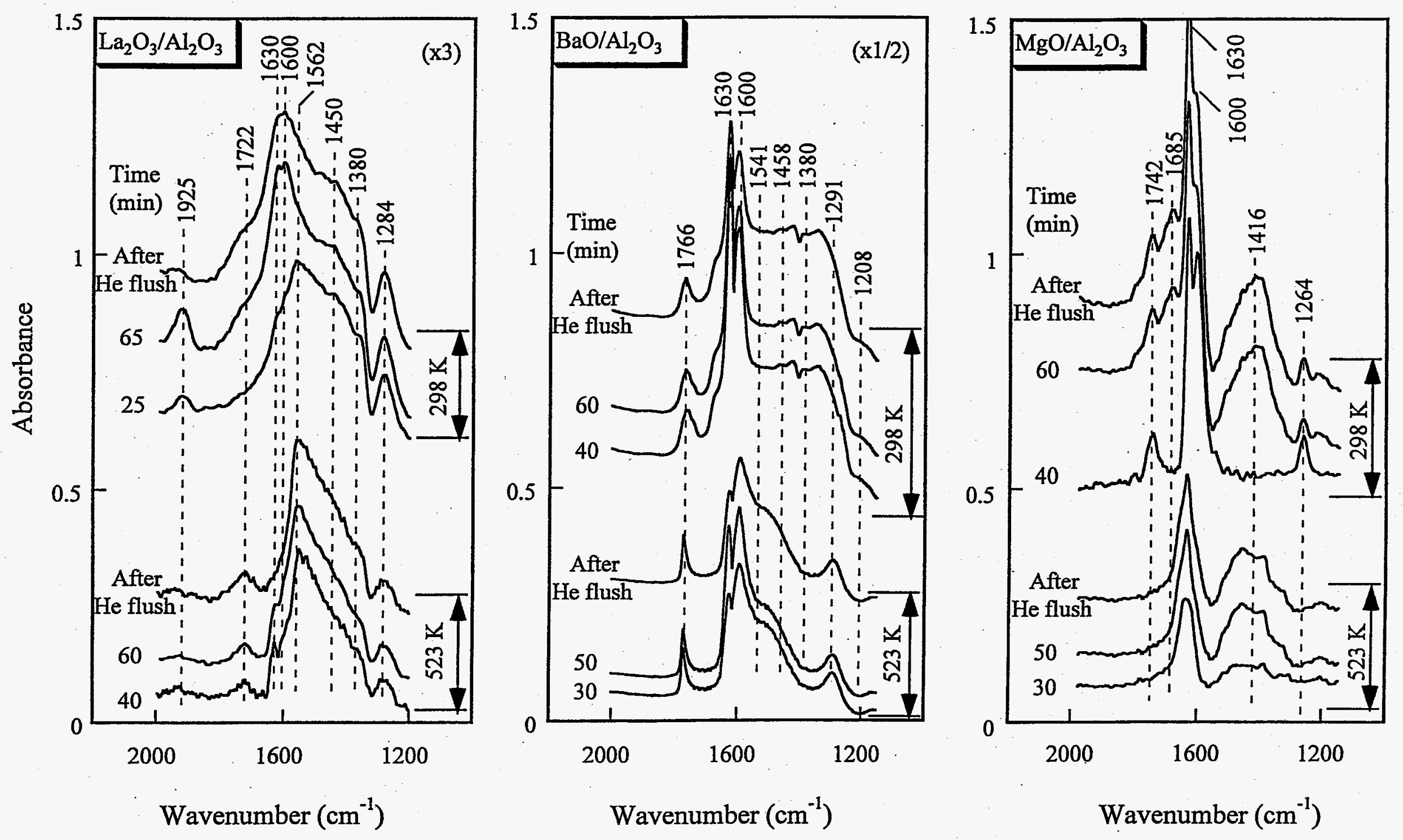


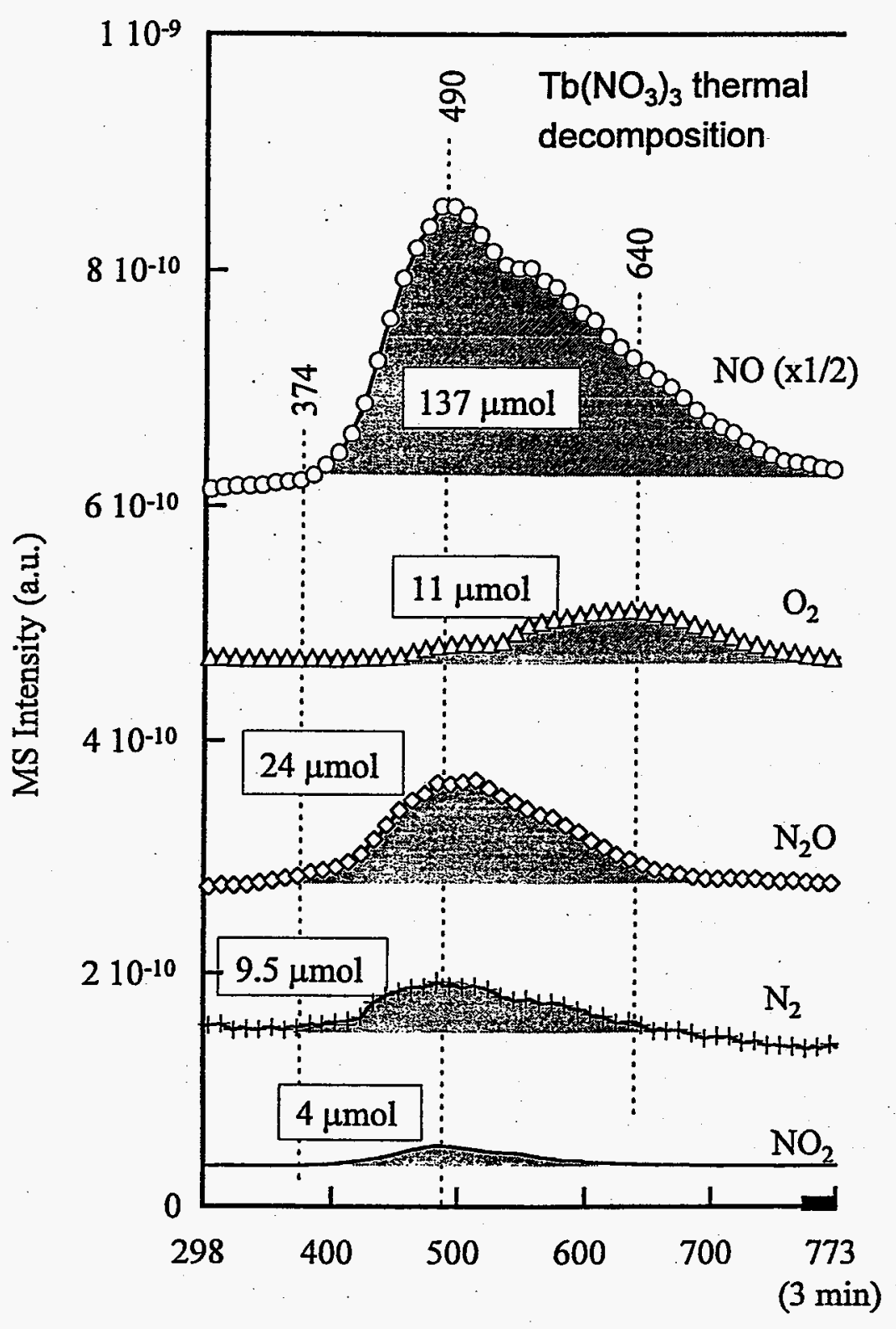

Temperature (K)
TPD from 298 - $773 \mathrm{~K}$
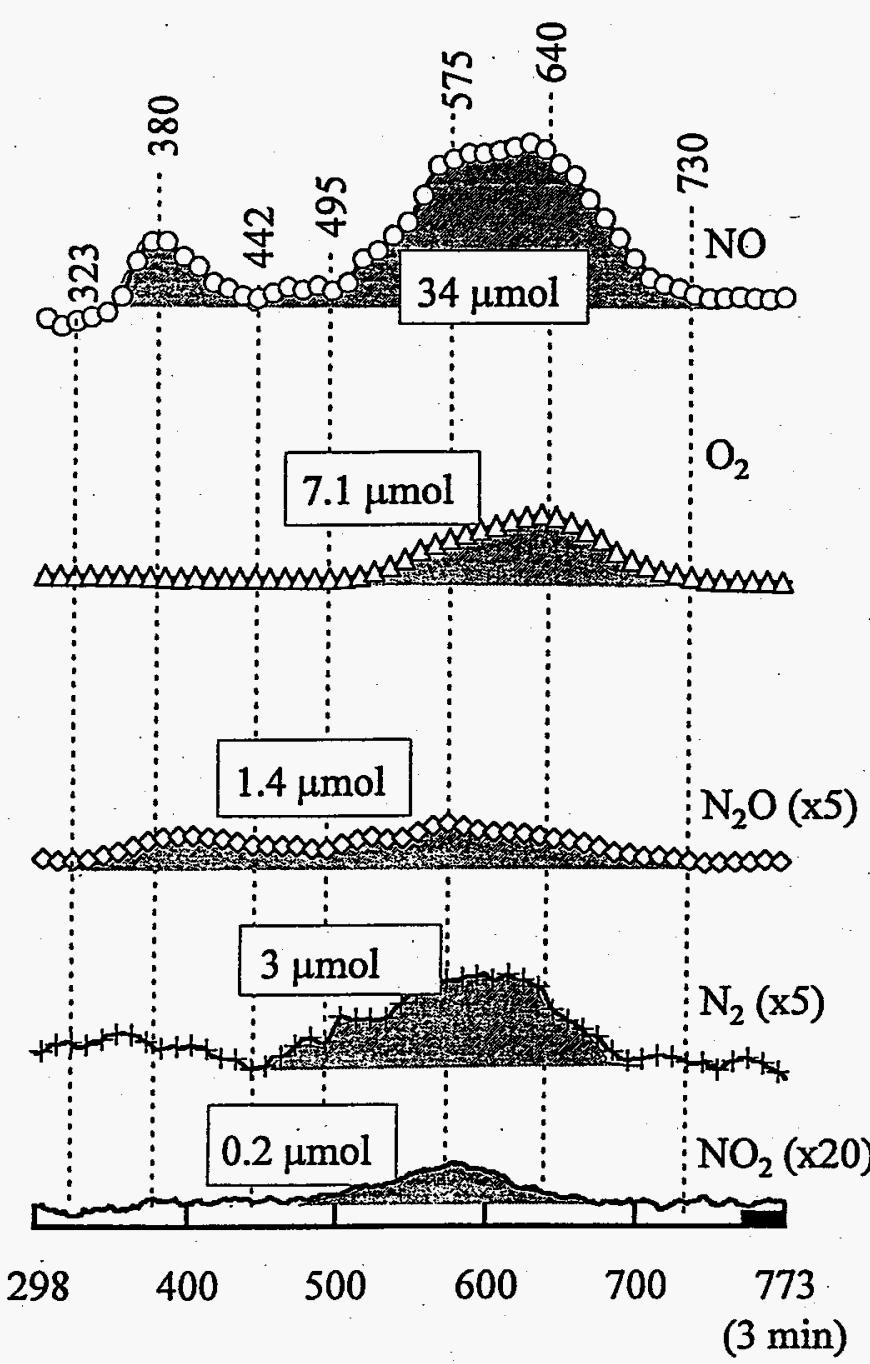

Temperature (K)
TPD from 523 - $773 \mathrm{~K}$
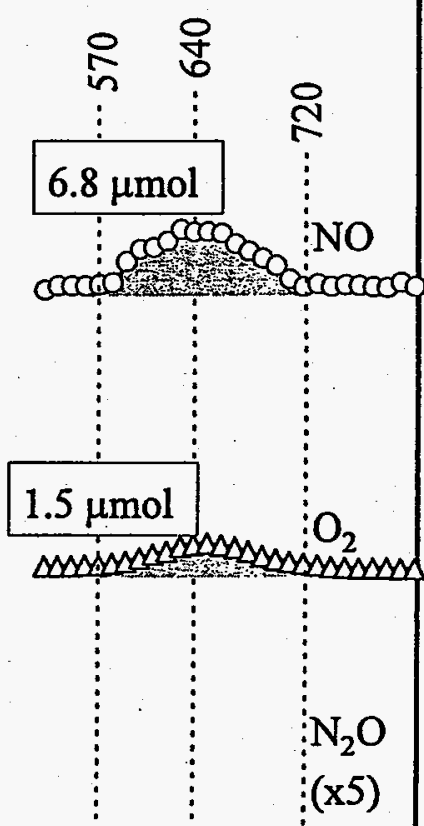

00000000000000000000

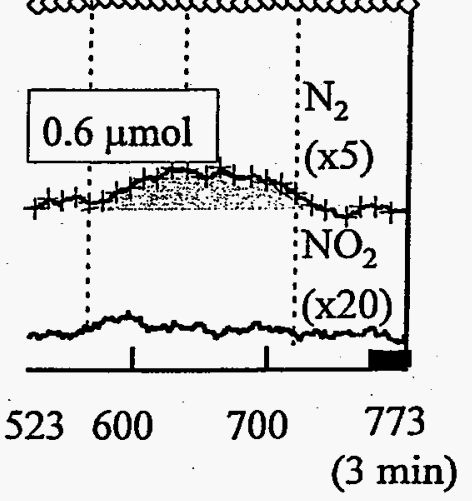

Temperature (K) 


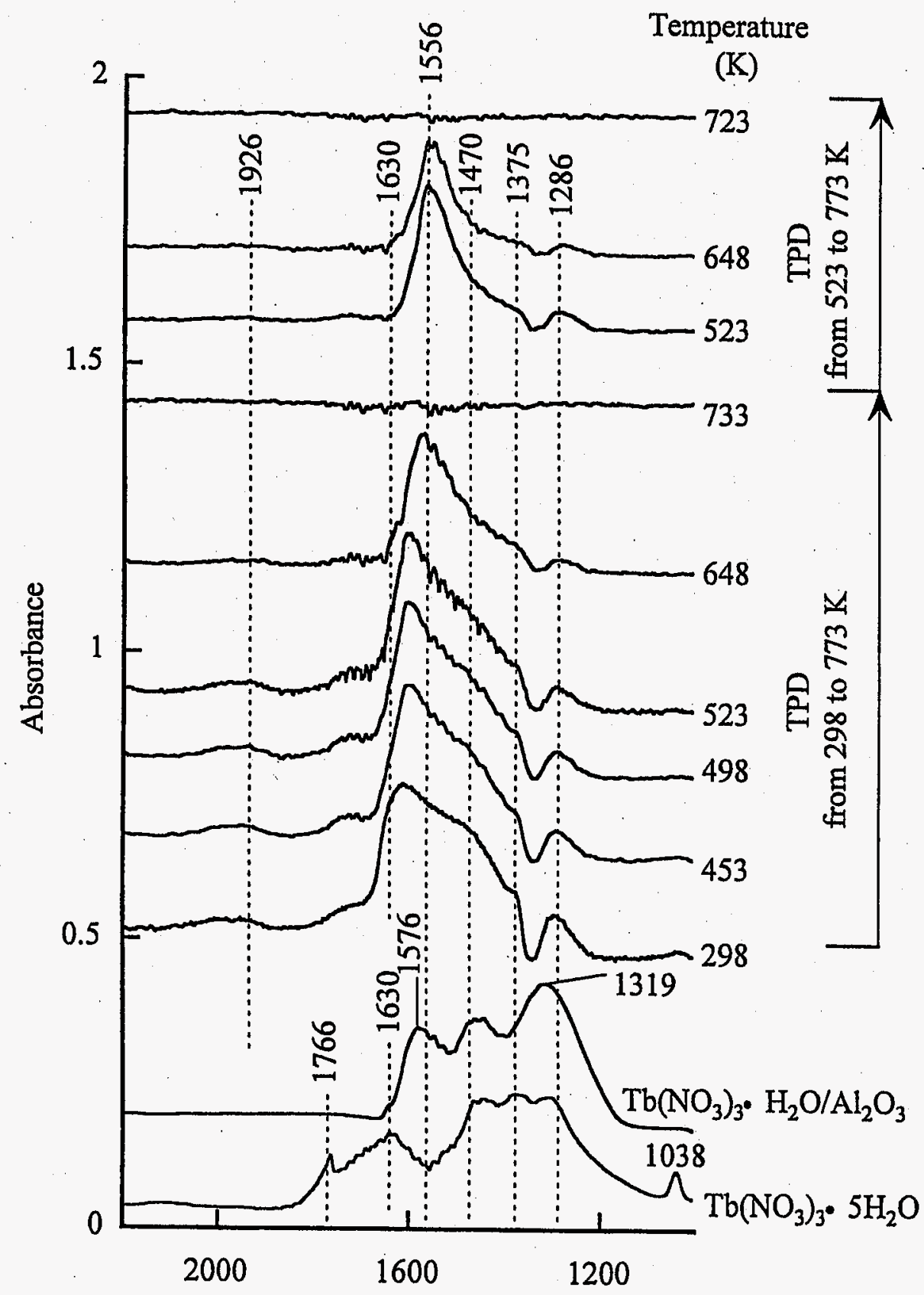

Fig.7 Chi \& Chuang 


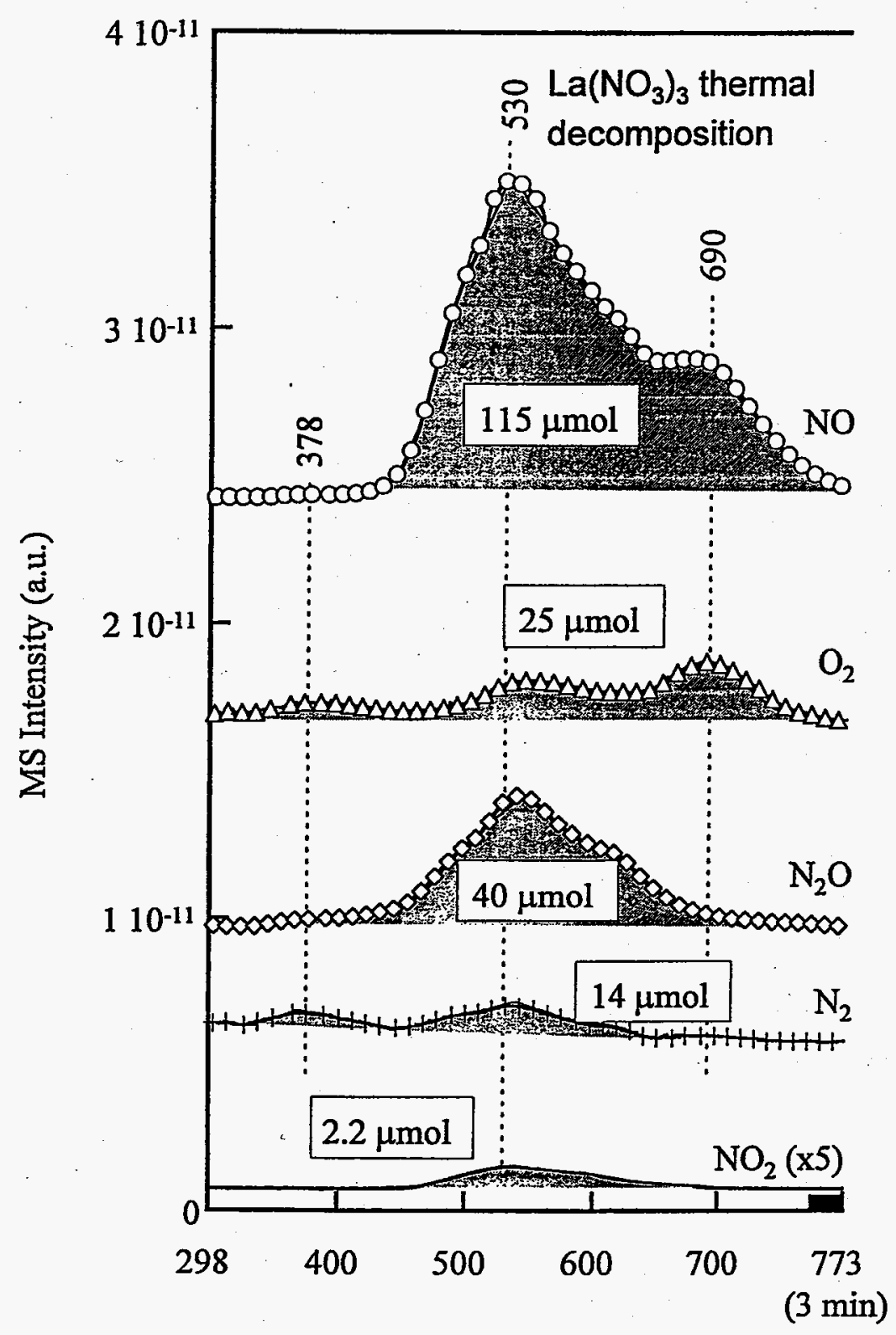

Temperature (K)
TPD from 298 - $773 \mathrm{~K}$

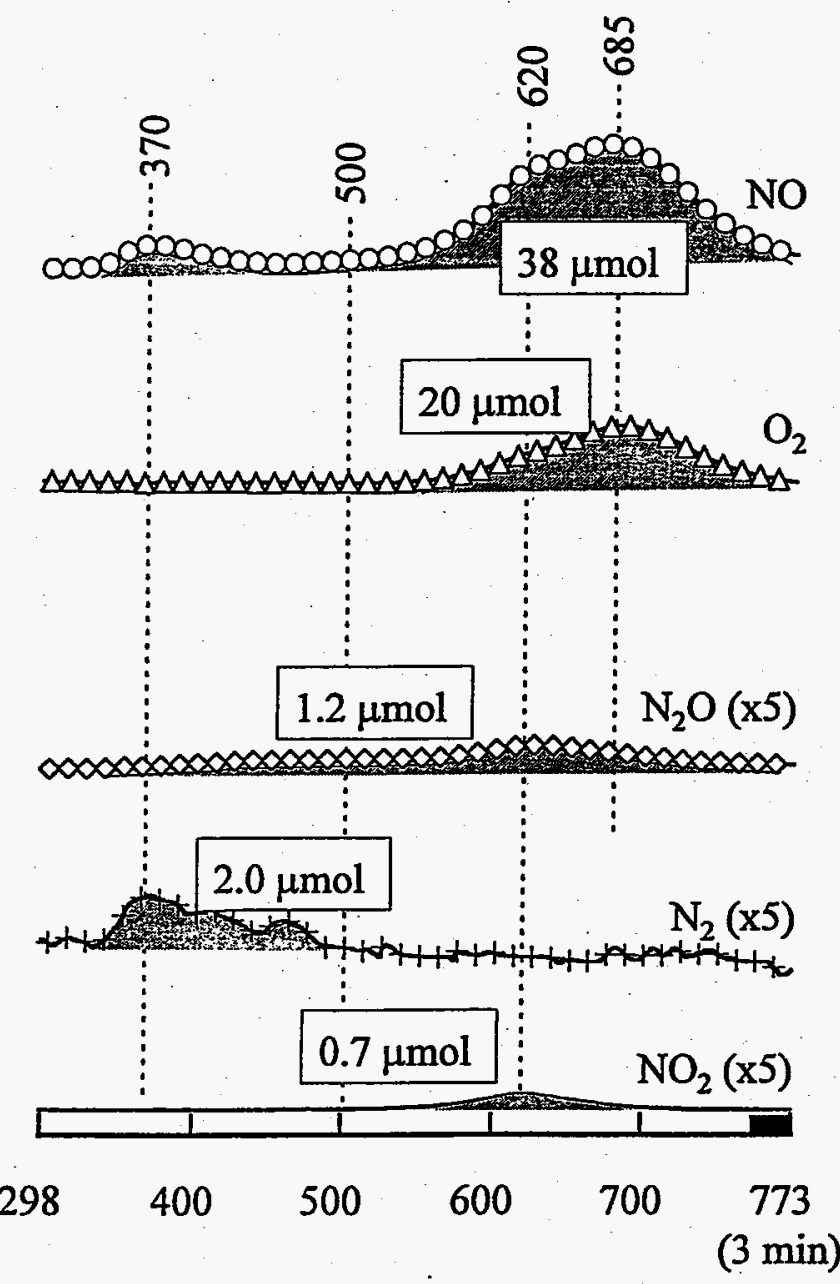

Temperature (K)
TPD from $523-773 \mathrm{~K}$

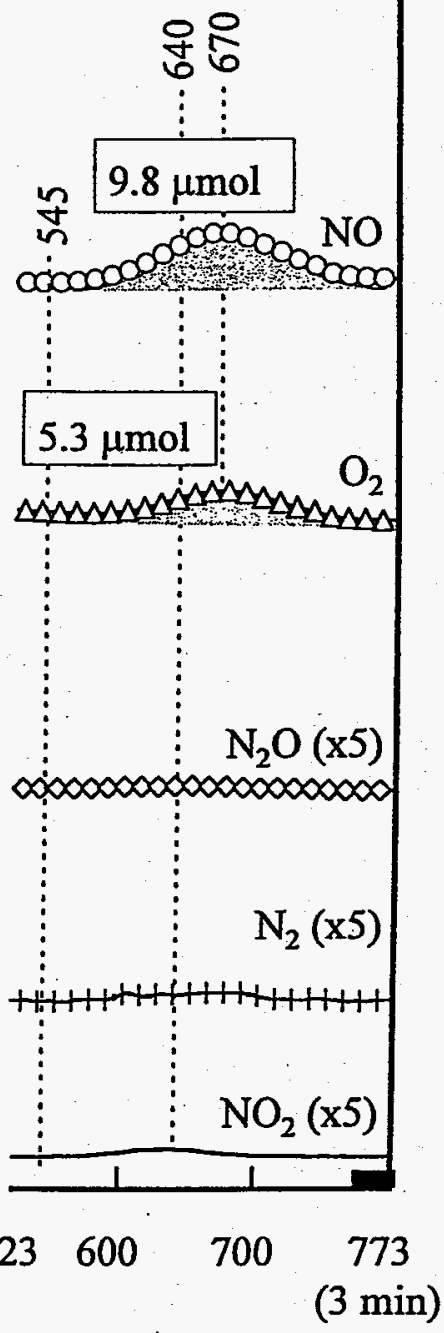

Temperature (K) 


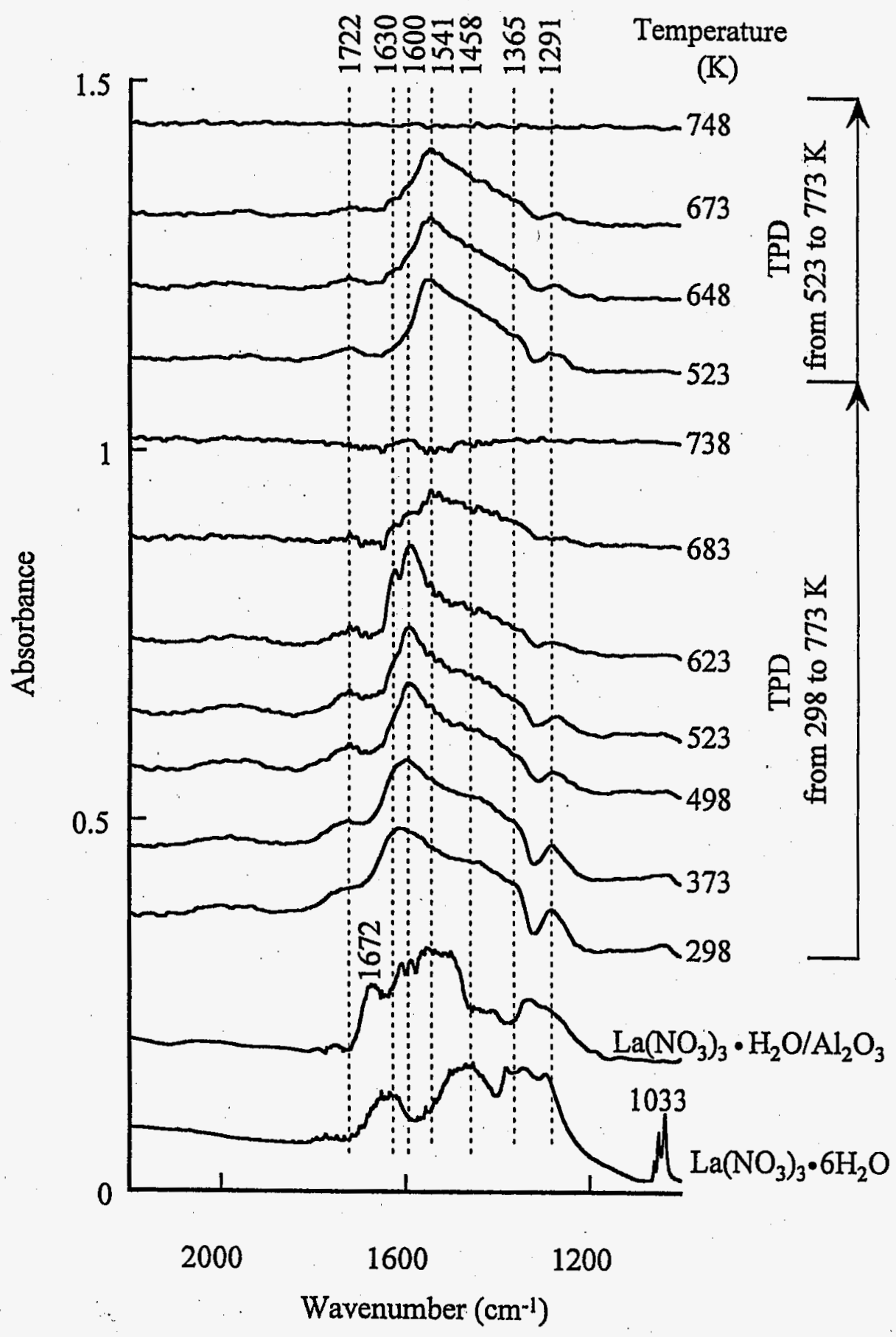

Fig.9 Chi \& Chuang 


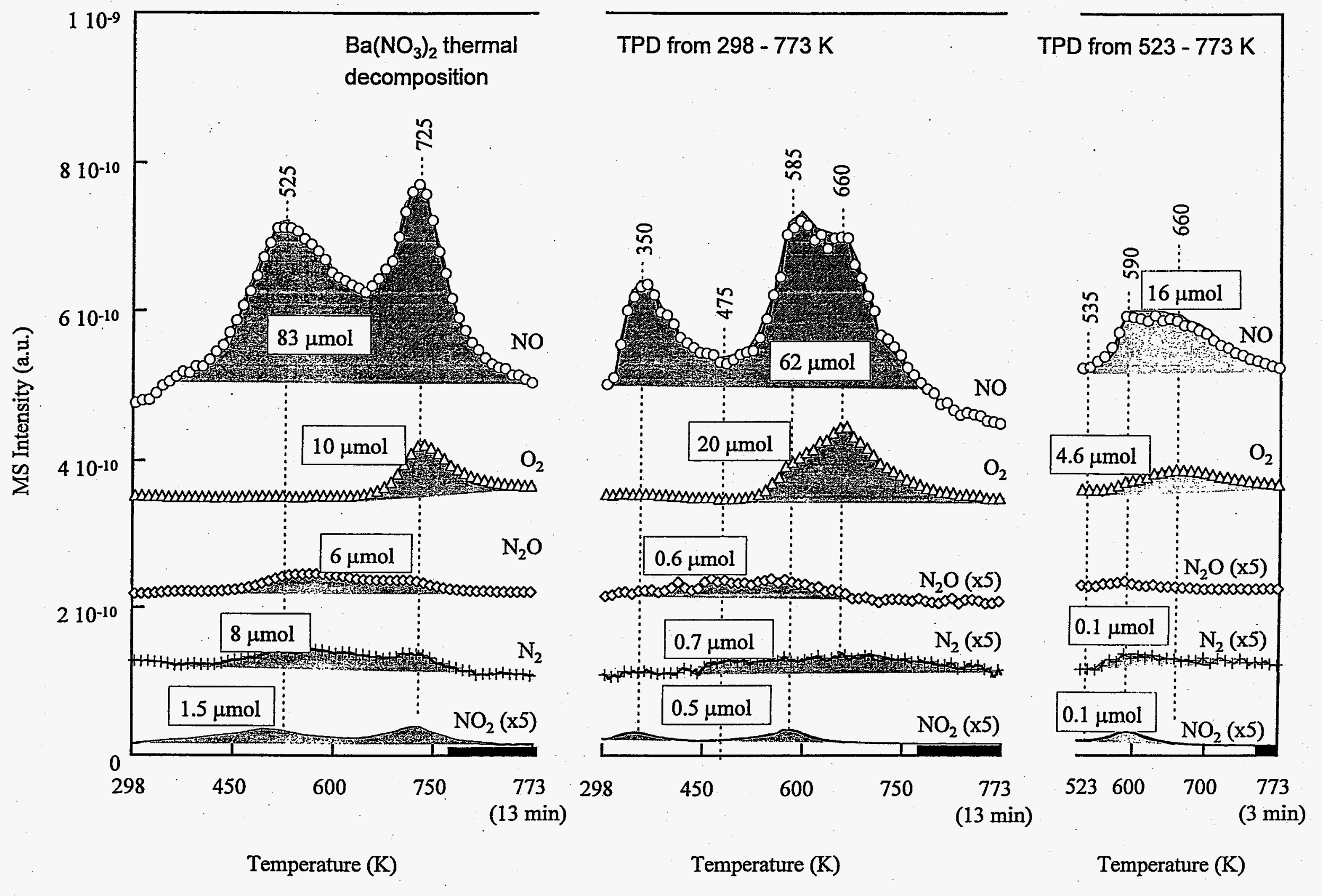

Fig.10 Chi \& Chuang 


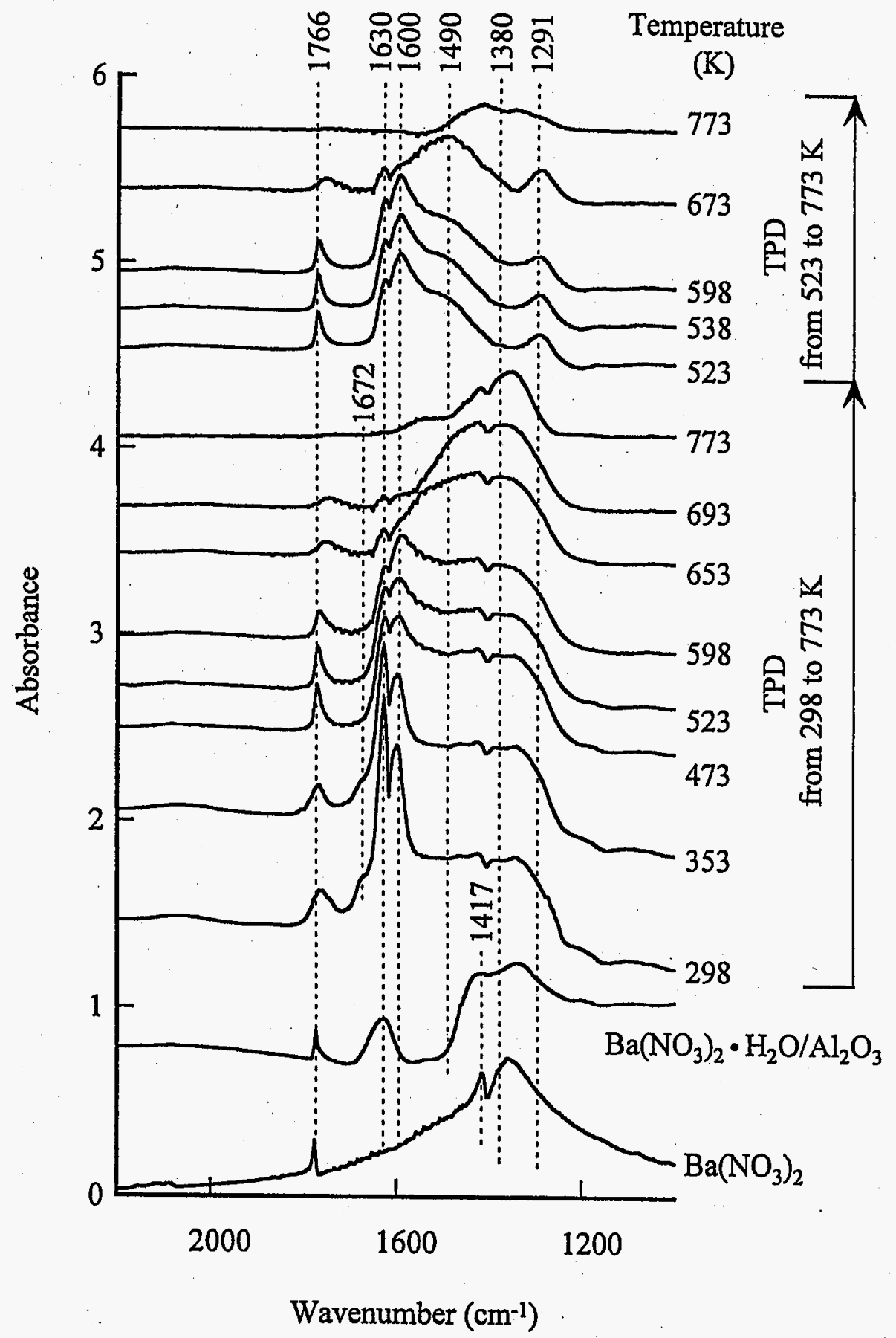




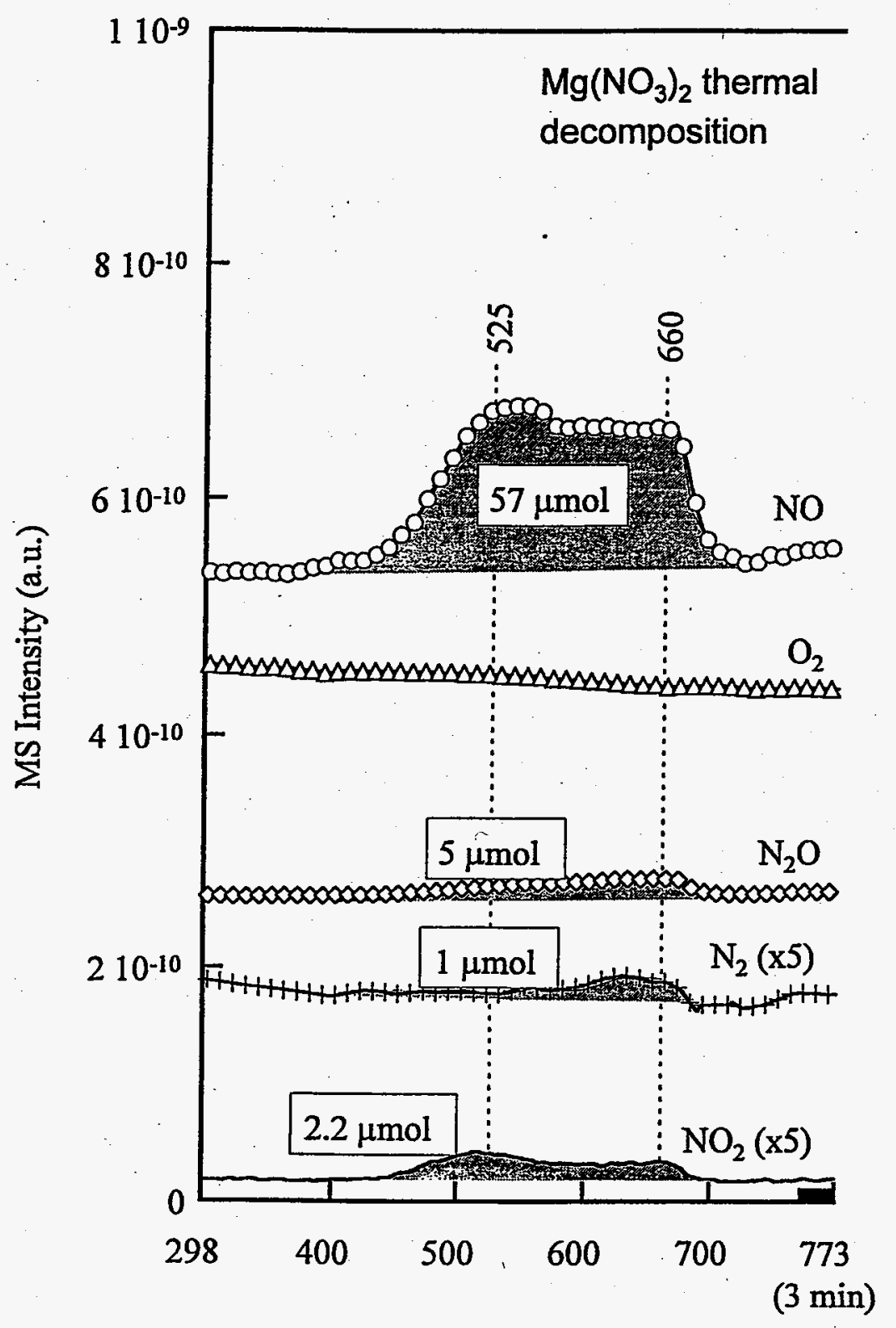

Temperature (K)

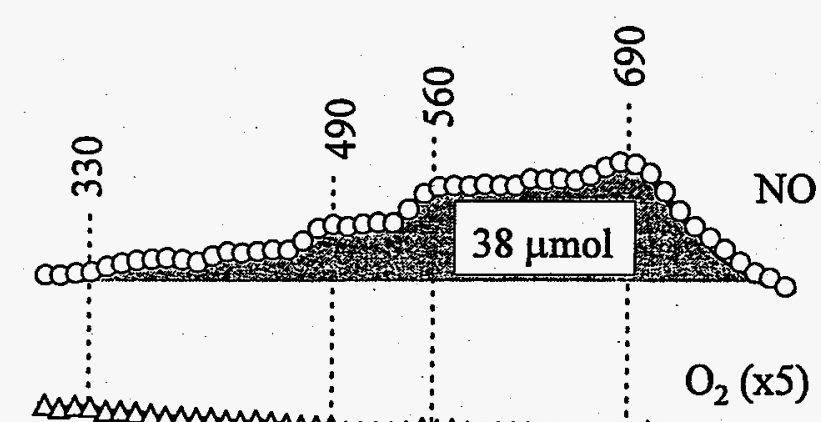

m
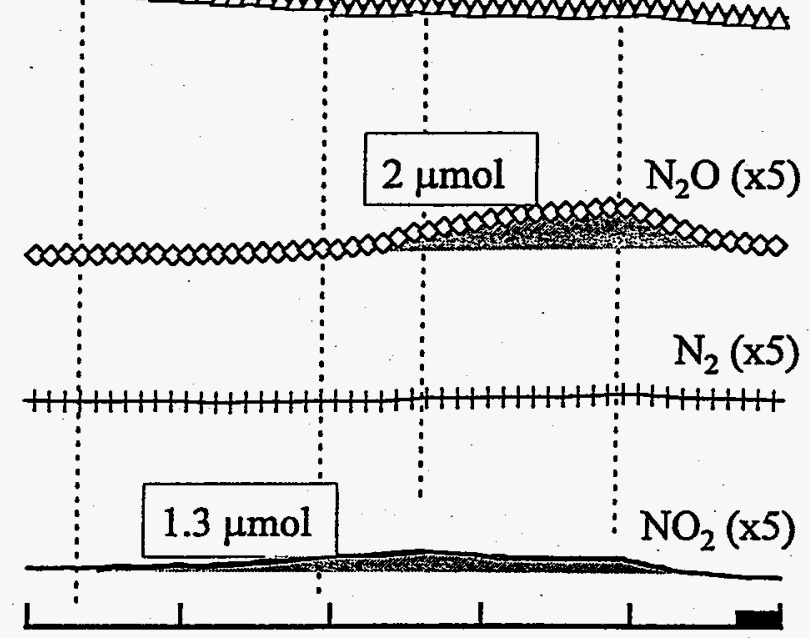

400

500

600

700

(3 $\mathrm{min})$

Temperature (K)

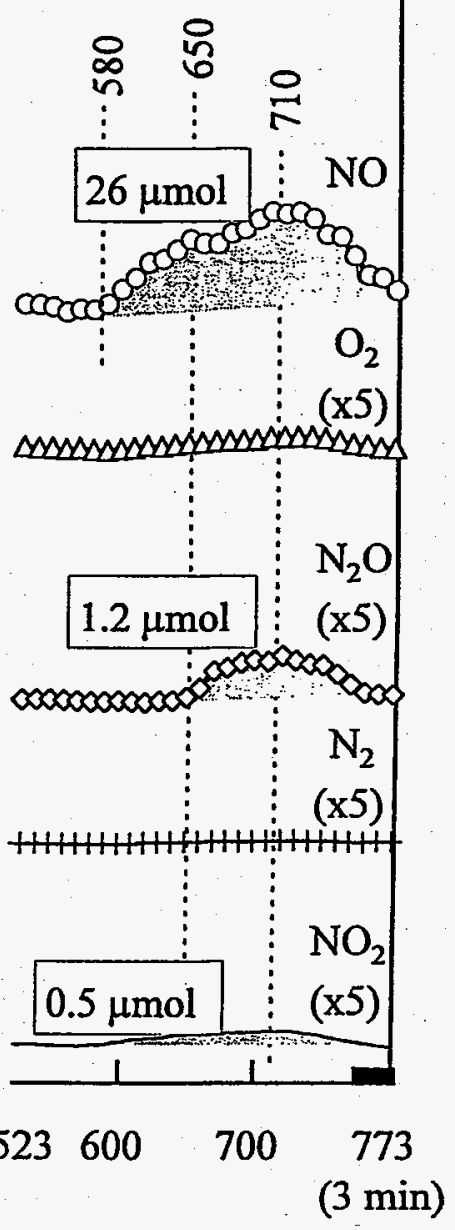

Temperature (K) 


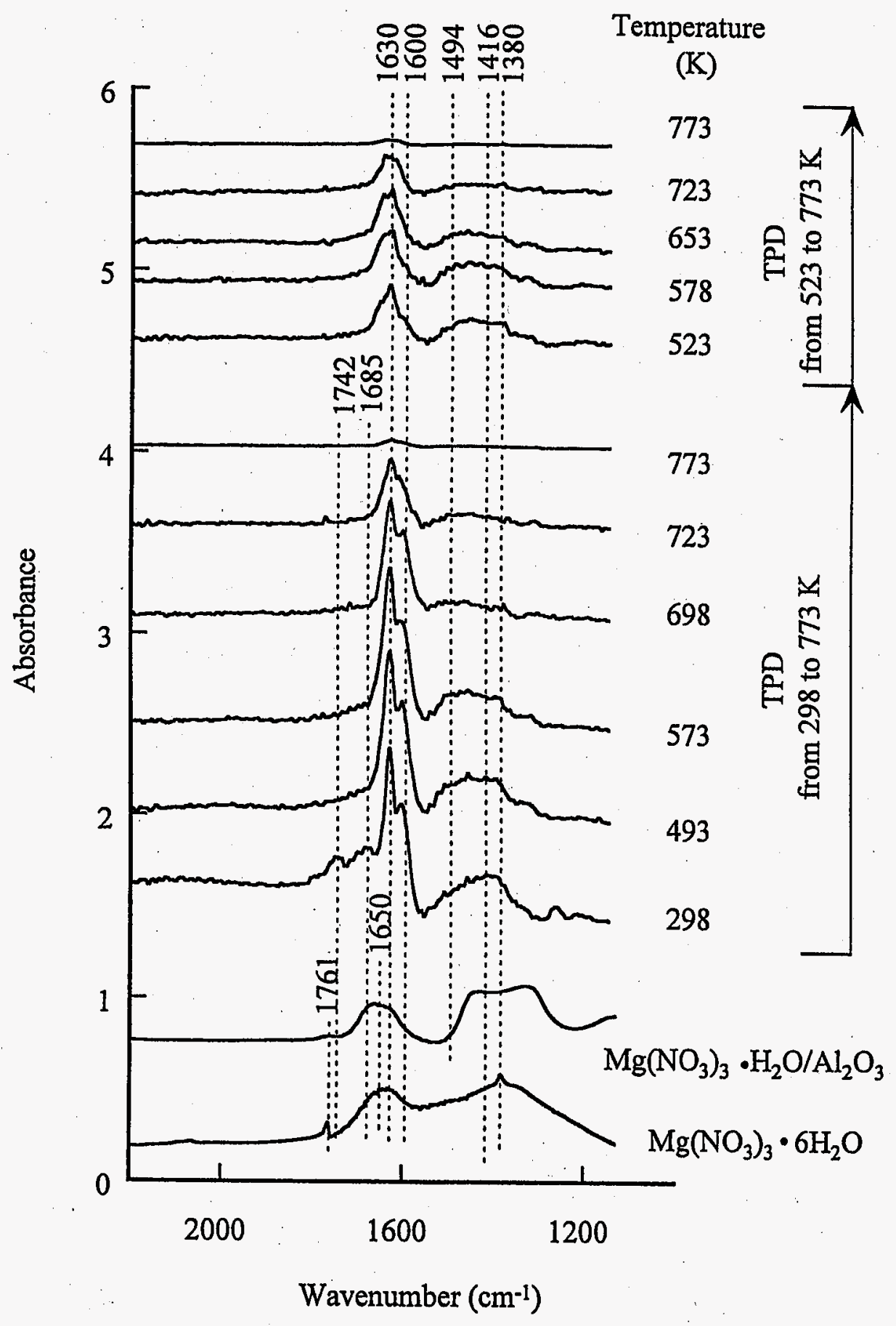

Fig.13 Chi \& Chuang 


\title{
Combined infrared and mass spectrometric study of reactions of adsorbed $\mathrm{NO}$ and $\mathrm{CO}$ on $0.5 \mathrm{wt} \% \mathrm{Rh} / \mathrm{SiO}_{2}$ catalyst
}

\author{
Steven S.C. Chuang ${ }^{*}$, Cher-Dip Tan \\ Department of Chemical Engineering, The University of Akron, Akron, OH 44325-3906, USA
}

\begin{abstract}
NO adsorption, $\mathrm{CO}$ adsorption, NO temperature-programmed desorption and decomposition (TPD), and temperature-programmed reaction (TPR) of NO-CO have been studied over $0.5 \mathrm{wt} \% \mathrm{Rh} / \mathrm{SiO}_{2}$ catalysts by a combined infrared and mass spectrometric technique. Infrared study reveals that the high wavenumber Rh-NO ${ }^{8-}$ at $1723-1740 \mathrm{~cm}^{-1}$ is the dominant adsorbate during TPD and TPR with NO:CO = 1:1. During TPR, $\mathrm{CO}$ reduces part of Rh surface resulting in the formation of the low wavenumber $\mathrm{Rh}-\mathrm{NO}^{\delta-}$ at $1634-1680 \mathrm{~cm}^{-1}$. Increasing $\mathrm{CO}$ partial pressure (i) promotes the formation of $\mathrm{Rh}^{0}$ sites, producing linear $\mathrm{CO}$, (ii) increases the selectivity to $\mathrm{N}_{2} \mathrm{O}$ below the light-off temperature, (iii) raises the light-off temperature, and (iv) promotes the formation of $\mathrm{Si}-\mathrm{NCO}$ and $\mathrm{Rh}-\mathrm{NCO}$. Comparison of results of the present study with those of previous studies on $4 \mathrm{wt} \% \mathrm{Rh} / \mathrm{SiO}_{2}$ shows that different dispersion of $\mathrm{Rh}$ crystallites on $\mathrm{SiO}_{2}$ support results in significant variation in chemisorptive and reactive properties of $\mathrm{Rh}$ metal for the NO-CO reaction.
\end{abstract}

Keywords: Infrared spectroscopy; Mass spectroscopy; $\mathrm{Rh} / \mathrm{SiO}_{2}$ catalyst

\section{Introduction}

In situ infrared (IR) spectroscopy has been widely used to study adsorbates on supported metal catalysts [1-7]. Infrared spectroscopy provides unique information on both properties of adsorbates and characteristics (i.e. oxidation state and geometric structure) of the surface sites that chemisorb adsorbates. Depending on the specific reaction conditions, adsorbates may follow various pathways: (i) desorbing to the gas phase and returning to its initial reactant form, (ii) surface reactions leading to the formation of both desired and side products, and (iii) residing on the surface and remaining inactive. Identification of the fate of an adsorbate re-

\footnotetext{
" Corresponding author.
}

quires simultaneous measurements of variation in concentration of adsorbates as well as that of gaseous reactants and products under transient conditions $[1,7,8]$. One effective approach for such measurements is a combined $\mathrm{IR}$ and mass spectrometric (MS) technique in which in situ IR spectroscopy measures the concentration of adsorbates and MS determines the concentration of the gaseous species resulting from interactions and reactions of the adsorbates.

Both IR and MS have been widely used in catalysis research. These techniques have often been used separately, resulting in the difficulty in correlating IR with MS results. Few studies using the combined IR and MS technique have been reported. An earlier combined IR-MS study of $\mathrm{NO}$ and $\mathrm{CO}$ adsorption on a $4 \mathrm{wt} \% \mathrm{Rh} / \mathrm{SiO}_{2}$ catalyst with $\mathrm{Rh}$ crystallite size of $63 \AA$ re- 
vealed that exposure of linear and gem-dicarbonyl CO to gaseous NO leads to desorption of both forms of adsorbed $\mathrm{CO}$ and adsorption of $\mathrm{NO}$ as $\mathrm{Rh}-\mathrm{NO}^{\delta-}$ and $\mathrm{Rh}-\mathrm{NO}^{\delta+}$ in the 298-413 $\mathrm{K}$ temperature range [9]. Transient IR-MS study also showed that adsorbed $\mathrm{NO}^{\delta-}$ on the surface of $\mathrm{Rh}$ crystallite is an active precursor for NO dissociation [10]. Due to the significant difference in $\mathrm{Rh}$ loading and dispersion between 4 wt\% $\mathrm{Rh} / \mathrm{SiO}_{2}$ and a three-way $\mathrm{Pt}-\mathrm{Rh}$ automobile catalyst, results obtained from $4 \mathrm{wt} \%$ $\mathrm{Rh} / \mathrm{SiO}_{2}$ may not be directly relevant to the behavior of adsorbates on the surface of the three-way catalyst.

The objective of this study is to determine the reaction pathways of adsorbed NO during temperature-programmed desorption, decomposition, and reaction with $\mathrm{CO}$ on $0.5 \mathrm{wt} \%$ $\mathrm{Rh} / \mathrm{SiO}_{2} .0 .5 \mathrm{wt} \% \mathrm{Rh} / \mathrm{SiO}_{2}$ contains highly dispersed $\mathrm{Rh}$ crystallite of which dispersion resembles that of $\mathrm{Rh}$ on the typical three-way catalyst. Results of this study are compared with those of $4 \mathrm{wt} \% \mathrm{Rh} / \mathrm{SiO}_{2}$ [8-10] and other results described in the literature to shed light on the behavior of adsorbed NO on the highly dispersed $\mathrm{Rh}$ catalysts under reaction conditions.

\section{Experimental}

The catalyst used in this study was a $0.5 \mathrm{wt} \%$ $\mathrm{Rh} / \mathrm{SiO}_{2}$ which was prepared by incipient wetness impregnation of large pore (Stream, 300 $\mathrm{m}^{2} \mathrm{~g}^{-1}$ ) $\mathrm{SiO}_{2}$ support with $\mathrm{RhCl}_{3} \cdot 3 \mathrm{H}_{2} \mathrm{O}$ (Alfa Chemicals) solution. The ratio of the volume of solution to the weight of support material used for the catalyst was $1 \mathrm{~cm}^{3}$ to $1 \mathrm{~g}$. After impregnation, the catalyst sample was dried overnight in air at $303 \mathrm{~K}$ and reduced in flowing $\mathrm{H}_{2}$ at $673 \mathrm{~K}$ for $16 \mathrm{~h}$. The catalyst was pressed into a thin disk and placed in an in situ $\mathrm{IR}$ reactor cell capable of operating up to $873 \mathrm{~K}$ and $6 \mathrm{MPa}$. The details of the in situ IR reactor cell, experimental apparatus, and procedures have been reported elsewhere [8]. The catalyst in the IR cell was further reduced with $\mathrm{H}_{2}$ at $673 \mathrm{~K}$ for 2 $\mathrm{h}$ prior to initiating the reaction study. The reaction mixture consisted of $\mathrm{CO}$ (Commercial grade), NO (UHP), and He (UHP) which were controlled by mass flow controllers.

Temperature-programmed desorption (TPD) of adsorbed NO was carried out at a heating rate of $15 \mathrm{~K} \mathrm{~min}^{-1}$ in flowing helium at $30 \mathrm{~cm}^{3}$ $\mathrm{min}^{-1}$; temperature-programmed reaction of $\mathrm{NO}-\mathrm{CO}$ was studied at a heating rate of $15 \mathrm{~K}$ $\min ^{-1}$ with a mixture of NO:CO:He $=10: 10: 30$ $\mathrm{cm}^{3} \min ^{-1}$ and NO:CO:He = 5:50:30 $\mathrm{cm}^{3}$ $\min ^{-1}$. The change in concentration of adsorbates was monitored by an FT-IR spectrometer with a resolution of $4 \mathrm{~cm}^{-1}$; the effluent from the IR reactor cell was monitored continuously using a Balzers QMG 112 quadrupole mass spectrometer (MS). The mass-to-charge $(\mathrm{m} / \mathrm{e})$ ratios monitored were 28 for $\mathrm{CO}$ and $\mathrm{N}_{2}, 30$ for $\mathrm{NO}$, and 44 for both $\mathrm{N}_{2} \mathrm{O}$ and $\mathrm{CO}_{2}$.

\section{Results and discussion}

Fig. 1 shows the infrared spectra of adsorbed $\mathrm{NO}$ at $303 \mathrm{~K}$ and $0.1 \mathrm{MPa}$ during temperature-

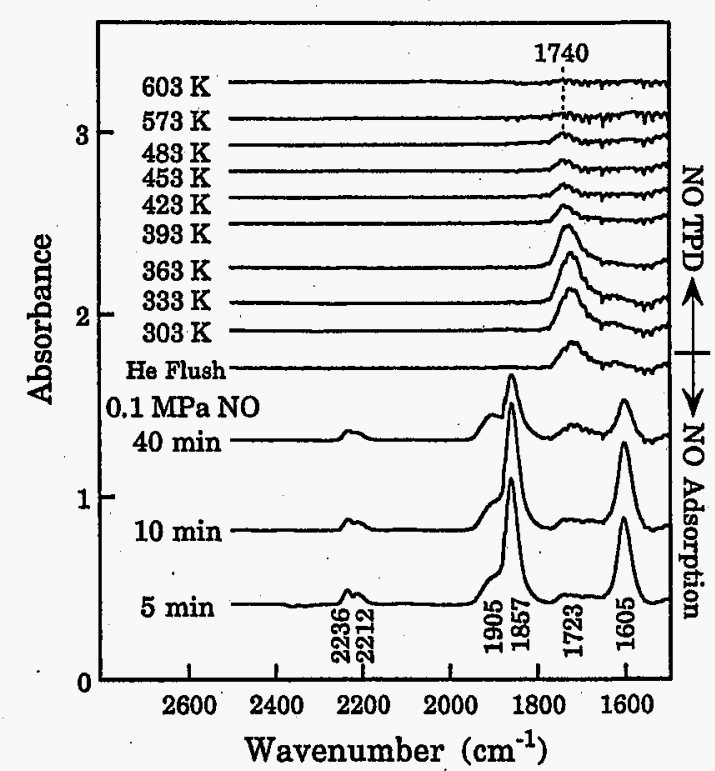

Fig. 1. IR spectra of NO adsorption at $303 \mathrm{~K}$ and $0.1 \mathrm{MPa}$ followed by temperature-programmed desorption on $0.5 \mathrm{wt} \%$ $\mathrm{Rh} / \mathrm{SiO}_{2}$. 
programmed desorption and decomposition. Exposure of $\mathrm{Rh} / \mathrm{SiO}_{2}$ catalyst to $0.1 \mathrm{MPa}$ of $\mathrm{NO}$ at $303 \mathrm{~K}$ in a batch mode produced gaseous $\mathrm{N}_{2} \mathrm{O}$ bands at 2236 and $2212 \mathrm{~cm}^{-1}$, weakly adsorbed $\mathrm{NO}$ on $\mathrm{SiO}_{2}$ at 1857 and $1605 \mathrm{~cm}^{-1}$, and adsorbed $\mathrm{NO}$ on $\mathrm{Rh}$ at $1723 \mathrm{~cm}^{-1}$. The $1723 \mathrm{~cm}^{-1}$ band may be assigned to a high wavenumber $\mathrm{Rh}-\mathrm{NO}^{\delta-}$ which will be further discussed. Prolonged exposure of the catalyst to. gaseous NO led to the growth of the band at $1723 \mathrm{~cm}^{-1}$ and decrease in the IR intensity of weakly adsorbed $\mathrm{NO}$ on $\mathrm{SiO}_{2}$. Gaseous $\mathrm{N}_{2} \mathrm{O}$ and weakly adsorbed NO were removed by flowing helium while the $\mathrm{Rh}-\mathrm{NO}^{\delta-}$ band continued to increase in intensity.

Fig. 1 also shows that temperature-programmed desorption of adsorbed NO caused a decrease in the $\mathrm{Rh}-\mathrm{NO}^{\delta-}$ intensity and an upward shift from $1723 \mathrm{~cm}^{-1}$ at $303 \mathrm{~K}$ to 1740 $\mathrm{cm}^{-1}$ at $483 \mathrm{~K}$. Closer examination reveals that the bands in $1723-1740 \mathrm{~cm}^{-1}$ region consist of at least two bands. These bands are centered about $1740 \mathrm{~cm}^{-1}$ at temperatures above $423 \mathrm{~K}$ and around $1723 \mathrm{~cm}^{-1}$ at temperatures below $423 \mathrm{~K}$. The change in wavenumber of the $\mathrm{Rh}-$ $\mathrm{NO}^{\delta-}$ from $1723 \mathrm{~cm}^{-1}$ to $1740 \mathrm{~cm}^{-1}$ appears to be a function of temperature where one form of $\mathrm{Rh}-\mathrm{NO}^{\delta-}$ converts to another with an increase in temperature. Clear distinction between these two bands is not possible; the difference in structure between the species contributing these two bands cannot be determined.

Assignment of the structure of adsorbed NO on the surface of Rh single crystal and supported $\mathrm{Rh}$ catalysts has been based on the presumed analogy in vibrational frequency between adsorbed NO on the metal surface and nitrosyl metal complex. Table 1 summarizes the similarities and the differences in vibrational frequencies of adsorbed $\mathrm{NO}$ on the surface of $\mathrm{Rh} / \mathrm{SiO}_{2}$, $\mathrm{Rh} / \mathrm{Al}_{2} \mathrm{O}_{3}$, and rhodium single crystal. The mode of adsorbed $\mathrm{NO}$ on $\mathrm{Rh}$ catalysts at room temperature has been found to strongly depend on the type of support and $\mathrm{Rh}$ dispersion. NO adsorption produced $\mathrm{Rh}-\mathrm{NO}^{\delta+}$ at $1920 \mathrm{~cm}^{-1}$, neutral $\mathrm{NO}$ at $1838 \mathrm{~cm}^{-1}$, gem-dinitrosyl $\mathrm{NO}$ at 1860 and $1780 \mathrm{~cm}^{-1}$, and $\mathrm{Rh}-\mathrm{NO}^{\delta-}$ at 1740 and $1660 \mathrm{~cm}^{-1}$ on $5 \mathrm{wt} \% \mathrm{Rh} / \mathrm{Al}_{2} \mathrm{O}_{3}$ [12] and $\mathrm{Rh}-\mathrm{NO}^{\delta+}$ at $1921 \mathrm{~cm}^{-1}$ and $\mathrm{Rh}-\mathrm{NO}^{\delta-}$ at 1746 and $1656 \mathrm{~cm}^{-1}$ on $4 \mathrm{wt} \% \mathrm{Rh} / \mathrm{SiO}_{2}$ [9]. It should be noted that the whole $\mathrm{Rh}-\mathrm{NO}^{\delta-}$ entity should be considered to be neutral. $\delta$ - represents the partial charge resulting from the transfer of electrons from $\mathrm{Rh}$ to NO. The difference in the wavenumber for $\mathrm{Rh}-\mathrm{NO}^{\delta-}$ at 1746 and $1656 \mathrm{~cm}^{-1}$ has been attributed to the different extent of electron back donation from the reduced Rh site to adsorbed NO. The bonding between $\mathrm{Rh}$ and $\mathrm{NO}^{\delta-}$ at $1656 \mathrm{~cm}^{-1}$ (i.e., the low wavenumber $\mathrm{Rh}-\mathrm{NO}^{\delta-}$ ) is presumably

Table 1

Vibrational frequencies $\left(\mathrm{cm}^{-1}\right)$ of $\mathrm{NO}$ on Rh catalysts

\begin{tabular}{|c|c|c|c|c|c|c|}
\hline & $\mathrm{Rh}-\mathrm{NO}^{8+}$ & $\mathrm{Rh}-\mathrm{NO}$ & Rh $\mathrm{NO}$ & $\mathrm{Rh}-\mathrm{NO}^{8-}$ & $\mathrm{Rh}_{\mathrm{NO}}$ & Ref. \\
\hline $1.2 \mathrm{wt} \% \mathrm{Rh} / \mathrm{Al}_{2} \mathrm{O}_{3}$ & $1910-1920$ & & $\begin{array}{l}1830_{\text {(as) }} \\
1740-1744_{(s)}\end{array}$ & & & [11] \\
\hline $5.0 \mathrm{wt} \% \mathrm{Rh} / \mathrm{Al}_{2} \mathrm{O}_{3}$ & 1920 & 1838 & $\begin{array}{l}1860_{(\mathrm{as})} \\
1770_{(\mathrm{s})}\end{array}$ & $\begin{array}{l}1740 \text { (high) } \\
1660 \text { (low) }\end{array}$ & & $-[12]$ \\
\hline $0.5 \mathrm{wt} \% \mathrm{Rh} / \mathrm{SiO}_{2}$ & & 1855 & & $\begin{array}{l}1723-1740 \text { (high) } \\
1634-1680 \text { (low) }\end{array}$ & & This study \\
\hline $4.0 \mathrm{wt} \% \mathrm{Rh} / \mathrm{SiO}_{2}$ & 1921 & & . & $\begin{array}{l}1740-1770 \text { (high) } \\
1650-1700 \text { (low) }\end{array}$ & & [9] \\
\hline $4.6 \mathrm{wt} \% \mathrm{Rh} / \mathrm{SiO}_{2}$ & & 1800 & & $\begin{array}{l}1685 \text { (high) } \\
1630 \text { (low) }\end{array}$ & & [13] \\
\hline $\begin{array}{l}5.0 \mathrm{wt} \% \mathrm{Rh} / \mathrm{SiO}_{2} \\
\mathrm{Rh}(111)\end{array}$ & 1910 & $\begin{array}{l}1830 \\
1840\end{array}$ & & $\begin{array}{l}1630-1690 \\
1620-1644\end{array}$ & $1510-1570$ & $\begin{array}{l}{[14]} \\
{[15,16]}\end{array}$ \\
\hline
\end{tabular}


stronger than that for $\mathrm{Rh}$ and $\mathrm{NO}^{\delta-}$ at 1746 $\mathrm{cm}^{-1}$ (the high wavenumber $\mathrm{Rh}-\mathrm{NO}^{\delta-}$ ).

Our recent temperature-programmed reduction (TPR) and transient studies have revealed that the high wavenumber $\mathrm{Rh}-\mathrm{NO}^{\delta-}$ at 1746 $\mathrm{cm}^{-1}$ is less stable than the low wavenumber $\mathrm{Rh}-\mathrm{NO}^{\delta-}$ at $1656 \mathrm{~cm}^{-1}[17]$; the low wavenumber $\mathrm{NO}^{\delta-}$ participated in NO dissociation during $\mathrm{NO}-\mathrm{CO}$ reaction on $4 \mathrm{wt} \% \mathrm{Rh} / \mathrm{SiO}_{2}$ with the average Rh crystallite size of $63 \AA$ at temperatures above $473 \mathrm{~K}$ [10]. The presence of both low and high wavenumber $\mathrm{Rh}-\mathrm{NO}^{\delta-}$ on the $4 \mathrm{wt} \% \mathrm{Rh} / \mathrm{SiO}_{2}$ and the absence of the low wavenumber $\mathrm{NO}^{8-}$ on $0.5 \mathrm{wt} \% \mathrm{Rh} / \mathrm{SiO}_{2}$ suggest that the low wavenumber $\mathrm{Rh}-\mathrm{NO}^{\delta-}$ is chemisorbed on the surface of large $\mathrm{Rh}$ crystallites. The high wavenumber $\mathrm{Rh}-\mathrm{NO}^{\delta-}$ appeared to be chemisorbed on the surface of highly dispersed $\mathrm{Rh}$ on $0.5 \mathrm{wt} \% \mathrm{Rh} / \mathrm{SiO}_{2}$. A high dispersion of $\mathrm{Rh}$ on $0.5 \mathrm{wt} \% \mathrm{Rh} / \mathrm{SiO}_{2}$ is also evidenced by the fact that $0.5 \mathrm{wt} \% \mathrm{Rh} / \mathrm{SiO}_{2}$ chemisorbed primarily linear $\mathrm{CO}$ as shown in Fig. 3.

EELS (Electron Energy Loss Spectroscopy) studies have shown that the surface of $\mathrm{Rh}(111)$ single crystal chemisorbs the low wavenumber $\mathrm{Rh}-\mathrm{NO}^{\delta-}$ at $1620-1644 \mathrm{~cm}^{-1}$ and $1510-1570$ $\mathrm{cm}^{-1}$ which have been assigned to a bent terminal NO and a bridged NO, respectively $[15,16]$. The low wavenumber $\left(1620-1644 \mathrm{~cm}^{-1}\right) \mathrm{Rh}-$ $\mathrm{NO}^{\delta-}$ observed on both $\mathrm{Rh}$ single crystal and supported $\mathrm{Rh}$ is in a bent form, exhibiting a $\mathrm{Rh}-\mathrm{N}-\mathrm{O}$ angle of $120^{\circ}$ [18]. Both $\mathrm{Rh}-\mathrm{NO}^{\delta+}$ and $\mathrm{Rh}-\mathrm{NO}$ on $\mathrm{Rh} / \mathrm{Al}_{2} \mathrm{O}_{3}$ and $\mathrm{Rh} / \mathrm{SiO}_{2}$ are in a linear form which is perpendicular to the $R h$ surface. $\mathrm{Rh}-\mathrm{NO}^{\delta+}$ has only been observed on the supported Rh while bridged NO has only been found on the single crystal surface. The formation of $\mathrm{Rh}-\mathrm{NO}^{\delta+}$ on $\mathrm{Rh} / \mathrm{SiO}_{2}$ and $\mathrm{Rh} / \mathrm{Al}_{2} \mathrm{O}_{3}$ is a result of either oxidation of the $\mathrm{Rh}$ surface by dissociative adsorption of NO or direct adsorption of $\mathrm{NO}$ on $\mathrm{Rh}^{+}$sites. The resistance of the $\mathrm{Rh}$ single crystal surface to oxidation during dissociative NO adsorption inhibits the formation of $\mathrm{Rh}^{+}$sites that chemisorb $\mathrm{NO}^{\delta+}$ and gem-dicarbonyl.

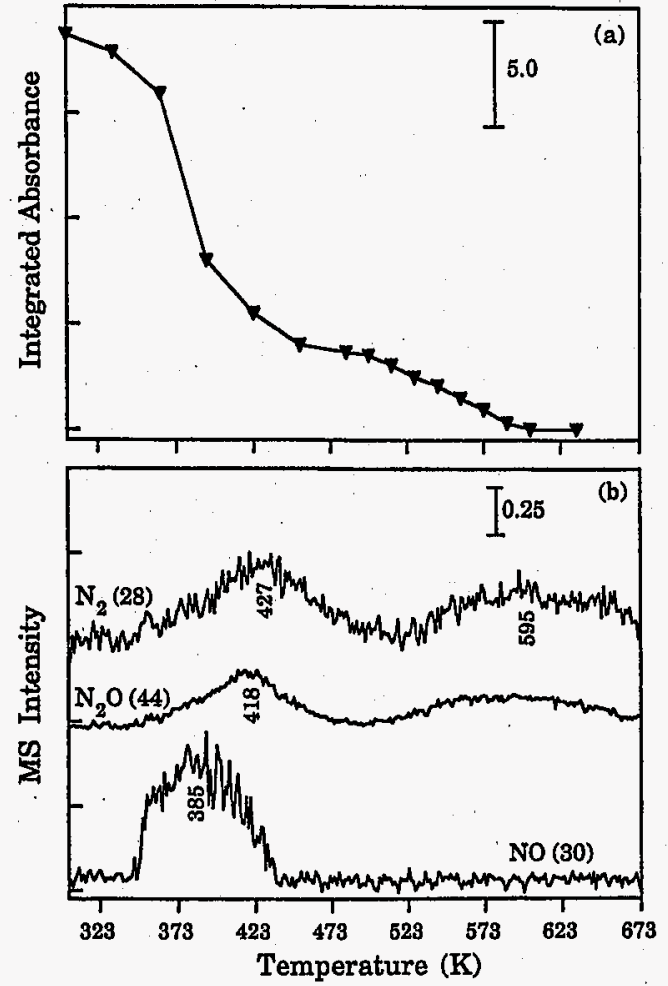

Fig. 2. (a) Variation of integrated absorbance between 1795 and $1460 \mathrm{~cm}^{-1}$ for $\mathrm{Rh}-\mathrm{NO}^{\delta-}$ band with temperature. (b) MS analysis of the effluent from the reactor for Fig. 1. Heating rate $=15 \mathrm{~K}$ $\min ^{-1}$. $\mathrm{He}=30 \mathrm{~cm}^{3} \mathrm{~min}^{-1}$.

The variation in the integrated intensity of the high wavenumber $\mathrm{Rh}-\mathrm{NO}^{\delta-}$ at $1723-1740$ $\mathrm{cm}^{-1}$ as a function of temperature is shown in Fig. 2(a); the variation in the composition of the IR cell effluent is shown in Fig. 2(b). The rapid decrease in IR intensity of $\mathrm{Rh}-\mathrm{NO}^{\delta-}$ in the 343-393 $\mathrm{K}$ temperature range corresponds to the desorption of adsorbed $\mathrm{NO}$ as gaseous $\mathrm{NO}$ and initial formation of $\mathrm{N}_{2}$ and $\mathrm{N}_{2} \mathrm{O}$, suggesting the high wavenumber $\mathrm{Rh}-\mathrm{NO}^{\delta-}$ is responsible for the formation of $\mathrm{N}_{2}$ and $\mathrm{N}_{2} \mathrm{O}$. Nevertheless, the extensive overlapping between 1723 and $1740 \mathrm{~cm}^{-1}$ does not allow determination of their contribution to the product formation. The first $\mathrm{N}_{2}$ peak centered at $427 \mathrm{~K}$ corresponds to $0.69 \mu \mathrm{mol}$ of $\mathrm{N}_{2}$; the $\mathrm{N}_{2} \mathrm{O}$ peak centered at 418 $\mathrm{K}$ correspond to $0.0053 \mu \mathrm{mol}$ of $\mathrm{N}_{2} \mathrm{O}$. The 
following reaction steps have been suggested to explain the formation of $\mathrm{N}_{2}$ and $\mathrm{N}_{2} \mathrm{O}$ products.

(a) $\mathrm{Rh}^{0}-\mathrm{NO}^{\delta-} \rightarrow \mathrm{Rh}^{0}-\mathrm{N}+\mathrm{Rh}-\mathrm{O}$

(b) $R h^{0}-\mathrm{N}+\mathrm{Rh}^{0}-\mathrm{N} \rightarrow \mathrm{N}_{2}+\mathrm{Rh}^{0}$

(c) $\mathrm{Rh}^{0}-\mathrm{NO}^{8-}+\mathrm{Rh}-\mathrm{N}$

$\rightarrow \mathrm{N}_{2}+\mathrm{Rh}-\mathrm{O}+\mathrm{Rh}$

(d) $\mathrm{Rh}^{0}-\mathrm{NO}^{\delta-}+\mathrm{Rh}^{0}-\mathrm{N} \rightarrow \mathrm{N}_{2} \mathrm{O}+2 \mathrm{Rh}^{0}$.

Steps (a) and (d) leading to $\mathrm{N}_{2} \mathrm{O}$ formation have been supported by ample evidence. Our recent pulse infrared study has shown that the low wavenumber $\mathrm{Rh}-\mathrm{NO}^{\delta-}$ in step (a) dissociates on the reduced $\mathrm{Rh}$ surface and the formation of $\mathrm{N}_{2} \mathrm{O}$ takes place on the reduced $\mathrm{Rh}$ sites [10]. Fig. 1 also shows that a significant amount of $\mathrm{N}_{2} \mathrm{O}$ was produced when the reduced $\mathrm{Rh}$ catalyst was exposed to NO. The formation of $\mathrm{N}_{2} \mathrm{O}$ from adsorbed NO via steps (a) and (d) should leave an adsorbed oxygen which may modify the Rh surface. On $4 \mathrm{wt} \% \mathrm{Rh} / \mathrm{SiO}_{2}$ and $5 \mathrm{wt} \% \mathrm{Rh} / \mathrm{Al}_{2} \mathrm{O}_{3}$ dissociative adsorption of NO, step (a), produced $\mathrm{Rh}^{+}$that chemisorbed $\mathrm{NO}$ as $\mathrm{Rh}-\mathrm{NO}^{\delta+}$. The absence of $\mathrm{Rh}-\mathrm{NO}^{\delta+}$ during NO adsorption and TPD indicates that $\mathrm{Rh}$ on $0.5 \mathrm{wt} \% \mathrm{Rh} / \mathrm{SiO}_{2}$ is not oxidized.

It should be noted that the low wavenumber $\mathrm{Rh}-\mathrm{NO}^{\delta-}$ is not present during TPD. Formation of $\mathrm{N}_{2} \mathrm{O}$ and $\mathrm{N}_{2}$ during TPD should be attributed to dissociation of high wavenumber $\mathrm{Rh}-\mathrm{NO}^{\delta-}, \mathrm{Rh}^{0}-\mathrm{NO}^{\delta-} \rightarrow \mathrm{Rh}-\mathrm{N}+\mathrm{Rh}-\mathrm{O}$. Adsorbed $\mathrm{N}$ and $\mathrm{NO}$ may follow steps (b) and (c) to produce a high temperature $\mathrm{N}_{2}$ peak at $595 \mathrm{~K}$ and a low temperature $\mathrm{N}_{2}$ peak at $427 \mathrm{~K}$, respectively. Step (c) is supported by the presence of adsorbed NO during the formation of $\mathrm{N}_{2}$ at $427 \mathrm{~K}$. The slightly lower peak temperature for $\mathrm{N}_{2} \mathrm{O}$ than for $\mathrm{N}_{2}$ at $427 \mathrm{~K}$ indicates that step (d) takes place at a slightly lower temperature than step (c). Dissociation of the high wavenumber $\mathrm{Rh}-\mathrm{NO}^{\delta-}$ is not a common ratedetermining step for the formation of $\mathrm{N}_{2}$ and $\mathrm{N}_{2} \mathrm{O}$. Simulation of TPD profiles for adsorbed NO have revealed that both steps (c) and (d) have the same activation energy on a $5 \mathrm{wt} \%$
$\mathrm{Rh} / \mathrm{SiO}_{2}$ [19]. The factors that direct the reaction selectivity toward either step (c) or step (d) remain to be investigated.

The absence of an $\mathrm{O}_{2}$ profile in Fig. 2 is consistent with the literature in that the oxygen produced from NO decomposition was not readily desorbed below 723 K $[15,19,20]$. During NO TPD, the $\mathrm{O}_{2}$ desorption peak occurred at $1,500 \mathrm{~K}$ on $\mathrm{Rh}(111)$ [15], $1060 \mathrm{~K}$ on $5 \%$ $\mathrm{Rh} / \mathrm{SiO}_{2}$ catalyst [19], and $1,100 \mathrm{~K}$ on $\mathrm{Rh}$ filament [20].

The infrared spectra and gaseous composition profile shown in Figs. 1 and 2(b) permit the determination of the integrated absorbance coefficient $\left(\bar{A}_{N O}\right.$ for $\mathrm{Rh}-\mathrm{NO}^{\delta-}$ by assuming that $\vec{A}_{N O}$ does not vary with the coverage of adsorbed NO and using the relation [21]

$\bar{A}_{\mathrm{NO}}=\frac{1}{\bar{C}_{\mathrm{NO}}} \int_{v_{1}}^{v_{2}} A(v) \mathrm{d} v$

where $\bar{C}_{\text {No }}$ is the moles of NO chemisorbed per cross sectional area of the catalyst disk. $A(v)$ is the adsorbate's absorbance which is the function of wavenumber $v$, and $v_{2}$ and $v_{1}$ are the upper and lower wavenumber bounds at 1795 and $1640 \mathrm{~cm}^{-1}$, respectively. The amount of NO adsorbed on the $0.5 \mathrm{wt} \% \mathrm{Rh} / \mathrm{SiO}_{2}$ catalyst prior to TPD was determined by summing up all the nitrogen containing species obtained from multiplying the area under the TPD profile for each species by its responding factor. The amount of NO adsorbed on $196 \mathrm{mg}$ of the catalyst was calculated to be $154.55 \mu \mathrm{l}$, which corresponds to an atomic dispersion based on a conservative estimation. $\overline{A_{\mathrm{NO}}}$ for $\mathrm{Rh}-\mathrm{NO}^{\delta-}$ is determined to be $1.91 \mathrm{~cm} / \mu$ mol.

Fig. 3 shows the IR spectra of adsorbed CO on $0.5 \mathrm{wt} \% \mathrm{Rh} / \mathrm{SiO}_{2}$ at $303 \mathrm{~K}$. Pulsing $25 . \mu 1$ of gaseous $\mathrm{CO}$ into helium flow did not produce adsorbed $\mathrm{CO}$, indicating that $\mathrm{CO}$ adsorption is a slow process. Exposure of the catalyst to gaseous $\mathrm{CO}$ in a batch mode produced an intense band for the linear $\mathrm{CO}$ at $2049 \mathrm{~cm}^{-1}$, a shoulder band at $2004 \mathrm{~cm}^{-1}$, and bridged $\mathrm{CO}$ bands at 1813 and $1761 \mathrm{~cm}^{-1}$ at $303 \mathrm{~K}$. The $\mathrm{CO}$ species 


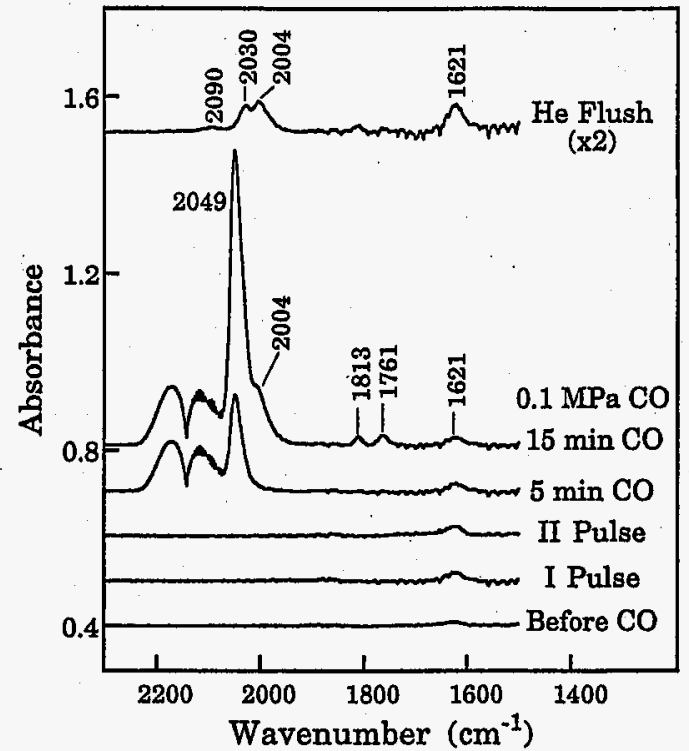

Fig. 3. IR spectra of $\mathrm{CO}$ adsorption on $0.5 \mathrm{wt} \% \mathrm{Rh} / \mathrm{SiO}_{2}$ at 303 K.

exhibiting these bands are weakly adsorbed on the surface. These species can be easily removed by flowing helium, leaving weak bands at 2030 and $2004 \mathrm{~cm}^{-1}$ which may be assigned to $\mathrm{Rh}(\mathrm{CO})_{4}$ [21]. It is unclear whether $\mathrm{Rh}(\mathrm{CO})_{4}$ is produced from either the direct adsorption of $\mathrm{CO}$ on $\mathrm{Rh}$ or transformation from linear CO. A significant fraction of the $2030 \mathrm{~cm}^{-1}$ band can be assigned to linear $\mathrm{CO}$ on $\mathrm{Rh}^{0}$ sites while a small fraction of the $2030 \mathrm{~cm}^{-1}$ and the 2090 $\mathrm{cm}^{-1}$ bands can be assigned to gem-dicarbonyl, $\mathrm{Rh}^{+}(\mathrm{CO})_{2}$. In situ infrared study has shown that the formation of gem-dicarbonyl involve the reaction

$$
\frac{1}{x} \mathrm{Rh}_{x}^{0}+\mathrm{OH}(\mathrm{a})+2 \mathrm{CO}_{(\mathrm{g})} \rightleftharpoons \mathrm{Rh}^{+}(\mathrm{CO})_{2}+\frac{1}{2} \mathrm{H}_{2}
$$

with $\mathrm{OH}(\mathrm{a})$ is the isolated $\mathrm{OH}$ on the surface of oxide support [3]. The reaction leading to the formation of gem-dicarbonyl is more facile on highly dispersed $\mathrm{Rh} / \mathrm{Al}_{2} \mathrm{O}_{3}$ than on $\mathrm{Rh} / \mathrm{SiO}_{2}$. The reaction process can be reversed upon treatment of gem-dicarbonyl with $\mathrm{H}_{2}$ above $200 \mathrm{~K}$. The low intensity of gem-dicarbonyl on 0.5 $\mathrm{wt} \% \mathrm{Rh} / \mathrm{SiO}_{2}$ can be attributed to the depletion of surface $\mathrm{OH}$ by reduction the catalyst with $\mathrm{H}_{2}$ at $673 \mathrm{~K}$.

Fig. 4 shows the IR spectra of adsorbates as a function of temperature during the temperatureprogrammed reaction (TPR) under an NO-CO$\mathrm{He}$ (NO:CO:He = 1:1:3) on $\mathrm{Rh} / \mathrm{SiO}_{2}$ catalyst. The initial spectrum prior to the NO-CO TPR shows a Rh-NO band at $1855 \mathrm{~cm}^{-1}$, a $\mathrm{Rh}-$ $\mathrm{NO}^{\delta-}$ band at $1723 \mathrm{~cm}^{-1}$, and two shoulder bands at 1680 and $1634 \mathrm{~cm}^{-1}$. These shoulder bands are assigned to the low wavenumber $\mathrm{Rh}-$ $\mathrm{NO}^{\delta-}$ on the reduced $\mathrm{Rh}$. Comparison of initial infrared spectra of adsorbed NO during TPD in Fig. 1 and during TPR in Fig. 4 shows that (i) the presence of $\mathrm{CO}$ in TPR results in the formation of adsorbed NO at 1634 and $1680 \mathrm{~cm}^{-1}$, indicating that $\mathrm{CO}$ kept $\mathrm{Rh}$ in a reduced state and (ii) the presence of $\mathrm{CO}$ inhibits the reaction to produce $\mathrm{N}_{2} \mathrm{O}$.

Fig. 5(a) highlights changes in the IR intensity of adsorbed NO at $1723 \mathrm{~cm}^{-1}$ with respect to temperature; Fig. 5(b) shows variation in the composition of the IR cell effluent during TPR. Increasing the temperature from 303 to $453 \mathrm{~K}$ led to a gradual decrease in the intensity of

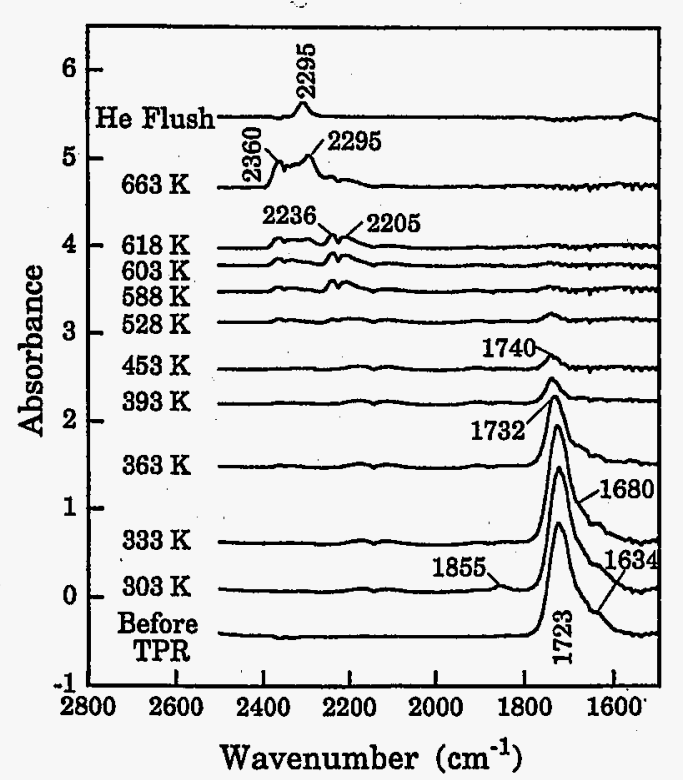

Fig. 4. IR spectra during the temperature-programmed reaction of $\mathrm{NO}-\mathrm{CO}-\mathrm{He}(1: 1: 3)$ on $\mathrm{Rh} / \mathrm{SiO}_{2}$. Heating rate $=15 \mathrm{~K} \mathrm{~min}{ }^{-1}$. $\mathrm{He}=30 \mathrm{~cm}^{3} \mathrm{~min}^{-1}$. 
adsorbed NO while conversion of reactants to products is negligible, indicating desorption of adsorbed NO. An appreciable conversion of reactants was observed at temperatures above 475 $\mathrm{K}$ where the high wavenumber $\mathrm{Rh}-\mathrm{NO}^{\delta-}$ band shifted to $1740 \mathrm{~cm}^{-1}$. The light-off temperature, at which $50 \%$ conversion occurs, was observed at $587 \mathrm{~K}$, where the intensity of adsorbed NO is about $2 \%$ of its initial intensity at $303 \mathrm{~K}$. The light-off temperature under the same reaction condition on $4 \mathrm{wt} \% \mathrm{Rh} / \mathrm{SiO}_{2}$ was determined to be $530 \mathrm{~K}$ [17]. The major IR-observable products at the light-off temperature are $\mathrm{CO}_{2}$ and $\mathrm{N}_{2} \mathrm{O}$ as shown by their intense IR bands. Because both $\mathrm{N}_{2} \mathrm{O}$ and $\mathrm{CO}_{2}$ give $m / e=44$, the quantitative analysis of these species is not possible with MS without monitoring the secondary ionization of $\mathrm{CO}_{2}, m / e=22$.

Nearly complete conversion of $\mathrm{NO}$ was achieved at temperatures above $663 \mathrm{~K}$ where
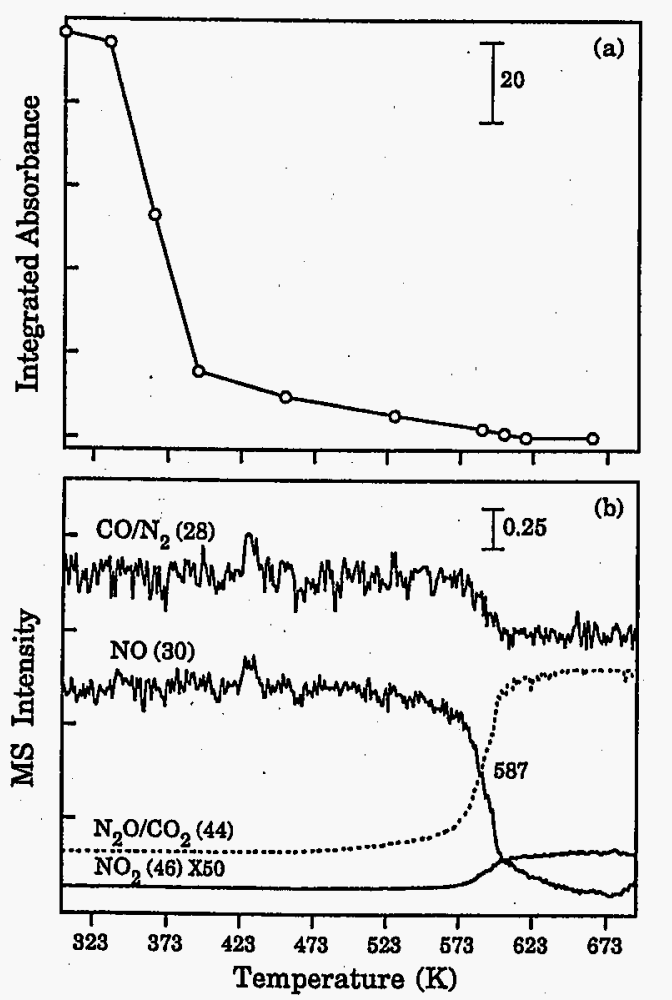

Fig. 5. (a) Variation of integrated absorbance between 1795 and $1460 \mathrm{~cm}^{-1}$ for $\mathrm{Rh}-\mathrm{NO}^{8-}$ band with temperature. (b) MS analysis of the effluent from the reactor for Fig. 4.

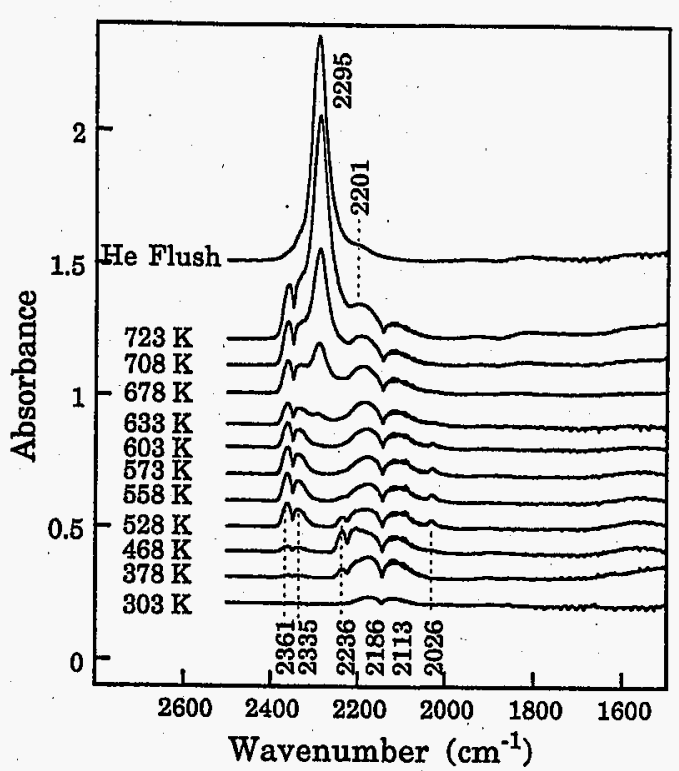

Fig. 6. IR spectra during the temperature-programmed reaction of $\mathrm{NO}-\mathrm{CO}-\mathrm{He}(1: 10: 6)$ on $\mathrm{Rh} / \mathrm{SiO}_{2}$. Heating rate $=15 \mathrm{~K} \mathrm{~min}^{-1}$. $\mathrm{He}=30 \mathrm{~cm}^{3} \mathrm{~min}^{-1}$.

the only noticeable adsorbate band was $\mathrm{Si}-\mathrm{NCO}$ at $2295 \mathrm{~cm}^{-1}$. The $\mathrm{Si}-\mathrm{NCO}$ band first appeared at $588 \mathrm{~K}$ and became prominent at $663 \mathrm{~K}$. $\mathrm{Si}-\mathrm{NCO}$ has been known to be a spectator species for $\mathrm{CO}_{2}$ formation which remains on the catalyst surface under flowing helium at temperature between $463-723 \mathrm{~K}[10,22]$. The absence of adsorbed $\mathrm{NO}$ and $\mathrm{CO}$ at temperatures above $618 \mathrm{~K}$ indicates that the concentration of these adsorbates is too small to be detected by IR.

In order to observe adsorbed CO during TPR, the ratio of NO to $\mathrm{CO}$ was adjusted to $1: 10$ to increase the concentration of adsorbed CO. Fig. 6 shows the IR spectra of the adsorbates. The reason of the absence of $\mathrm{CO}$ adsorbate at $303 \mathrm{~K}$ is not clear. Fig. 7 exhibits the composition profile of the IR cell effluent as a function of temperature during TPR with $\mathrm{NO}: \mathrm{CO}: \mathrm{He}=$ 1:10:6. $\mathrm{N}_{2} \mathrm{O}$ and $\mathrm{CO}_{2}$ bands emerged at $378 \mathrm{~K}$. Formation of $\mathrm{N}_{2} \mathrm{O}$ and $\mathrm{CO}_{2}$ occurred at significantly lower temperatures than those of the TPR study with $\mathrm{NO}: \mathrm{CO}: \mathrm{He}=1: 1: 3$. Fig. 7 shows that $m / e=44$ starts to increase in intensity at $378 \mathrm{~K}$, confirming the formation of $\mathrm{N}_{2} \mathrm{O}$ and 


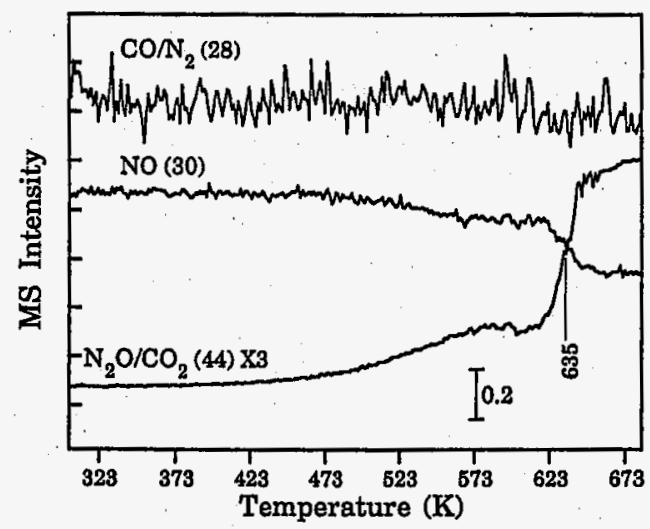

Fig. 7. MS analysis of the effluent from the reactor for Fig. 6.

$\mathrm{CO}_{2}$. Formation of $\mathrm{N}_{2} \mathrm{O}$ from NO-CO reaction has been shown to occur on the reduced $\mathrm{Rh}$ surface [10]. The high concentration of $\mathrm{CO}$ appears to keep a portion of the $\mathrm{Rh}$ in the reduced form, enhancing the formation of $\mathrm{N}_{2} \mathrm{O}$ and $\mathrm{CO}_{2}$. The presence of reduced $\mathrm{Rh}$ site is also evidenced by the linear $\mathrm{CO}$ band at $2026 \mathrm{~cm}^{-1}$ which emerged at $468 \mathrm{~K}$.

The light-off of the reaction took place at 635 $\mathrm{K}$ where $\mathrm{Rh}-\mathrm{NCO}$ at $2201 \mathrm{~cm}^{-1}$ and $\mathrm{Si}-\mathrm{NCO}$ at $2295 \mathrm{~cm}^{-1}$ began to appear. $\mathrm{Si}-\mathrm{NCO}$ is formed by spillover of isocyanates from the rhodium surface onto the support $[10,22]$. The high concentration of $\mathrm{CO}$ favors the formation of both $\mathrm{Rh}-\mathrm{NCO}$ and $\mathrm{Si}-\mathrm{NCO}$. By varying the partial pressure of $\mathrm{CO}$ and $\mathrm{NO}$ on $5 \mathrm{wt} \%$ $\mathrm{Rh} / \mathrm{SiO}_{2}$, it was also found that an increase in the partial pressure of $\mathrm{CO}$ led to an increase in the $\mathrm{Rh}-\mathrm{NCO}$ intensity and a decrease in the $\mathrm{Rh}-\mathrm{NO}^{\delta-}$ intensity [23].

A comparison of the behavior of adsorbed $\mathrm{NO}$ and $\mathrm{CO}$ on $0.5 \mathrm{wt} \% \mathrm{Rh} / \mathrm{SiO}_{2}$ and $4 \mathrm{wt} \%$ $\mathrm{Rh} / \mathrm{SiO}_{2}$ shows that the different dispersion of $\mathrm{Rh}$ crystallite leads to distinct differences in chemisorptive and reactivity properties [8-10]. Both linear and bridged $\mathrm{CO}$ are weakly bonded to the surface of the highly dispersed $\mathrm{Rh}$, but strongly bonded to the surface of large $\mathrm{Rh}$ crystallites. During the TPR of NO-CO (1:1) reaction, the high wavenumber $\mathrm{Rh}-\mathrm{NO}^{\delta-}$ is the dominant adsorbate on $0.5 \mathrm{wt} \% \mathrm{Rh} / \mathrm{SiO}_{2}$ while gem-dicarbonyl and both low and high wavenumber $\mathrm{Rh}-\mathrm{NO}^{\delta-}$ are present below the light-off temperature and linear $\mathrm{CO}$ is the major adsorbate above the light-off temperature on 4 wt\% $\mathrm{Rh} / \mathrm{SiO}_{2} .4 \mathrm{wt} \% \mathrm{Rh} / \mathrm{SiO}_{2}$ shows higher activity for NO-CO reaction with a lower lightoff temperature than $0.5 \mathrm{wt} \% \mathrm{Rh} / \mathrm{SiO}_{2}$. The high light-off temperature for $0.5 \mathrm{wt} \% \mathrm{Rh} / \mathrm{SiO}_{2}$ may be related to its high wavenumber $\mathrm{Rh}-$ $\mathrm{NO}^{\delta-}$ which has less propensity for dissociation than the low wavenumber $\mathrm{Rh}-\mathrm{NO}^{\delta-}$.

\section{Conclusions}

The $0.5 \mathrm{wt} \% \mathrm{Rh} / \mathrm{SiO}_{2}$ gives highly dispersed $\mathrm{Rh}$ which chemisorbs $\mathrm{NO}$ as the high wavenumber $\mathrm{Rh}-\mathrm{NO}^{\delta-}$ at $1740-1723 \mathrm{~cm}^{-1}$ and chemisorbs $\mathrm{CO}$ as linear, bridged, and $\mathrm{Rh}(\mathrm{CO})_{4}$. The bonding for $\mathrm{Rh}-\mathrm{NO}^{\delta-}$ is significantly stronger than that for $\mathrm{Rh}-\mathrm{CO}$. During TPD of $\mathrm{Rh}^{-\mathrm{NO}^{\delta-}}{ }^{-}$, adsorbed NO decomposed to $\mathrm{N}_{2}$ as a major product and $\mathrm{N}_{2} \mathrm{O}$ as a minor product. The NO-CO TPR shows that $\mathrm{CO}$ reduces a portion of the $\mathrm{Rh}$ sites, promoting the formation of $\mathrm{N}_{2} \mathrm{O}$ at $378 \mathrm{~K}$. For the TPR, increasing $\mathrm{CO}$ partial pressure from NO:CO:He $=1: 1: 3$ to $\mathrm{NO}: \mathrm{CO}: \mathrm{He}=1: 10: 6$ caused a progressive increase in NO conversion and a significant increase in $\mathrm{Rh}-\mathrm{NCO}$ and $\mathrm{Si}-\mathrm{NCO}$ concentration. Results of this study and previous studies on $4 \mathrm{wt} \% \mathrm{Rh} / \mathrm{SiO}_{2}$ show that differences in $\mathrm{Rh}$ dispersion can lead to significant variation in chemisorptive properties and reactivity of the Rh surface. A systematic understanding of the effect of dispersion on the nature of adsorption sites and reactivity remains to be investigated.

\section{Acknowledgements}

The authors gratefully acknowledge partially financial support of this research from the U.S. Department of Energy (grant number DE-FG2295PC95224). 


\section{References}

[1] Y.E. Li and R.D. Gonzalez, J. Phys. Chem., 92 (1988) 1589.

[2] W. Delgass, G. Haller, R. Kellerman and J. Lunsford, Spectroscopy in Heterogeneous Catalysis, Academic Press, New York, 1979.

[3] P. Basu, D. Panayotov, and J. T. Yates, J.r., J. Am. Chem. Soc., 110 (1988) 2074.

[4] J.T. Yates, Jr. and T.E. Madey (Editors), Vibrational Spectroscopy of Molecules on Surfaces, Plenum Press, New York, 1987.

[5] K. Tamaru, in J. Anderson and M. Boudart (Editors), Catalysis: Science and Technology, Vol. 9, Springer Veriag, Berlin/Heidelberg/New York, 1991, p. 87.

[6] S.I. Pien and S.S.C. Chuang, J. Mol. Catal., $68^{\circ}(1991) 313$.

[7] S.S.C. Chuang and S.I. Pien, J. Catal., 135 (1992) 618.

[8] S.S.C. Chuang, M. A. Brundage, M. W. Balakos and G. Srinivas, Appl. Spec. 49(8) (1995) 1151.

[9] G. Srinivas, S.S.C. Chuang and S. Debnath, J. Catal., 148 (1994) 748.

[10] R. Krishnamurthy and S.S.C. Chuang, J. Phys. Chem., 99 (1995) 16727.

[11] E.A. Hyde, R. Rudham and C.H. Rochester, J. Chem. Soc., Faraday Trans. 1, 80 (1984) 531.

[12] S. Solymosi, T. Bansagi and E. Novak, J. Catal., 112 (1988) 183.
[13] W.C. Hecker and A.T. Bell, J. Catal., 84 (1983) 200.

[14] B.J. Savatsky and A.T. Bell, ACS Symp. Ser., 178 (1982) 105.

[15] T.W. Root, G.B Fisher and L.D Schmidt, J. Chem. Phys., 85(8) (1986) 4679.

[16] G.B. Fisher, C.L. DiMaggio and D.D. Beck, in L. Guczi, F. Solymosi and P. Tetenyi (Editors), Proceedings of the 10th International Congress on Catalysis, 19-24 July, 1992, Part A, Elsevier, Amsterdam, 1992, p. 383.

[17] S.S.C. Chuang, R. Krishnamurthy and G. Srinivas, in U.S. Ozkan, S.K. Agarwal and G. Marcelin (Editors), Reduction of Nitrogen Oxide Emissions, ACS Symposium, Vol. 587, Am. Chem. Soc., Washington, DC, 1995, Chap. 14, p. 183.

[18] N.J. Connelly, Inorg. Chim. Acta, 6 (1972) 47.

[19] A.A. Chin and A.T. Bell, J. Phys. Chem., 87 (1983) 3700.

[20] B.E. Nieuwenhuys, in R.W. Joyner and R.A. van Santen (Editors), Elementary Reaction Steps in Heterogeneous Catalysis, Kluwer Academic Publishers, Dordrecht, Netherlands, 1993, p. 155.

[21] S.S.C. Chuang, R. Krishnamurthy and C.D. Tan, Coll. and Surf. A: Physicochemical and Eng. Aspects, 105 (1995) 35.

[22] G. Srinivas, S.S.C. Chuang and S. Debnath, in J.N. Armor (Editor), Environmental Catalysis, ACS Symposium Series, Vol. 552, Am. Chem. Soc., Washington, DC, 1994, Chap. 12 , p. 158.

[23] W.C. Hecker and A.T. Bell, J. Catal., 85 (1984) 389. 